Maria Aurineide Rodrigues

\title{
Sinalização no ganho de competência para a conversão de meristemas apicais radiculares de Catasetum fimbriatum em gemas caulinares
}

Tese apresentada ao Instituto de Biociências da Universidade de São Paulo, para a obtenção de Título de Doutor em Ciências, na Área de Botânica.

Orientador: Prof. Dr. Gilberto Barbante Kerbauy

São Paulo

2008 


\section{Ficha Catalográfica}

\section{São Paulo}

2008

Rodrigues, Maria Aurineide

Sinalização no ganho de competência para a conversão de meristemas apicais radiculares de Catasetum fimbriatum em gemas caulinares

Número de páginas: 175

Tese (Doutorado) - Instituto de Biociências da Universidade de São Paulo. Departamento de Botânica.

1. Meristema apical radicular 2. Hormônios vegetais 3. Organogênese I. Universidade de São Paulo. Instituto de Biociências. Departamento de Botânica.

\section{Comissão Julgadora:}

$\operatorname{Prof}(a) \cdot \operatorname{Dr}(a)$

Prof(a). Dr(a).
Prof(a). Dr(a).

Prof(a). Dr(a).

Prof. Dr. Gilberto Barbante Kerbauy

Orientador 


\section{Dedico}

Aos meus pais Manoel e Liduina, ao meu irmão Denis e ao meu amigo e companheiro Luciano: meus pilares e exemplos de amor, carinho e coragem. 
"Para que resulte o possível deve ser tentado o impossível."

(Hermann Hesse) 


\section{AgRADECIMENTOS}

Agradeço sinceramente ao Prof. Dr. Gilberto Barbate Kerbauy pela orientação e, acima de tudo, pelo apoio incondicional durante toda a minha formação acadêmica, pela amizade e exemplo de caráter, humildade e seriedade na pesquisa.

À Profa. Dra Helenice Mercier pela amizade, pelo exemplo de dedicação e, principalmente, pelas oportunidades de aprendizado sobre a importância do trabalho em equipe.

Aos professores Dra Maria Magdalena Rossi, Dr. Gregório Cardoso Tápias Ceccantini e Dr. Eduardo Purgatto pela amizade e colaboração ativa em diferentes fases desse trabalho.

Ao Luciano, meu amigo, companheiro e colaborador em todas as etapas desse trabalho, pela paciência, amizade, carinho e dedicação impossíveis de serem expressos em palavras: você faz parte de tudo que essa tese representa.

À amiga e colaboradora Vera, por todo apoio desde o início da minha vida acadêmica, pela alegria, conselhos e auxílio nas análises histológicas.

Aos amigos de trabalho e de vida (Lia, Thaís, Aline Bertinatto, Camila, Cássia, Cíntia, e Alessandra) pelo companheirismo, ajuda incondicional e amizade sincera.

Aos demais amigos e colegas de trabalho do Laboratório de Fisiologia Vegetal (Patrícia, Ilton, Paulo, Priscilla, Adriana Yepes, Aline Cavalari, Giovanna, Amanda, Adriana Grandis, Marcelo, Ivã, Maraba, Bruna, Leila, Laura, Flávia, Luís e Mari), pelo convívio diário repleto de alegria, respeito e colaboração mútua.

Aos amigos e colegas do Laboratório de Biologia Molecular de Plantas (Marisa, Douglas, Marcelo, Maria Elisa, Alessandro, Nilo, Jú, Dany Milstein, Dani K., Luísa, Vivi, Úrsula, Hana, Breno, Bruno, Jonas, Guilherme e Edgar) pela amizade, ajuda e ensinamentos.

Aos ex-membros do Laboratório de Fisiologia Vegetal e Biologia Molecular de Plantas (Rosete, Wagner, Rogério, Kátia, Regina, Adélia, Catarina, Ana Paula Vaz, Vivian, Thalita, Beatriz, Érika, Regininha, Myna, Priscilla e Ana Paula Costa), pela acolhida no laboratório, ensinamentos, convívio agradável e exemplo de dedicação.

À Ana Maria, Leonor e Ingrid pela amizade, alegria do convívio diário e por viabilizar as condições técnicas necessárias para o desenvolvimento de parte desse trabalho. 
Aos técnicos Gisele (Laboratório de Anatomia Vegetal), Rosário (Laboratório de Algas Marinhas), Morisa (Laboratório de Fitoquímica), Sílvia e Jú (Laboratório de Biologia Molecular de Plantas), Valdir e Evandro (Laboratório de Biologia Celular e Microscopia Eletrônica e Confocal) por todo o auxílio e prestatividade, e à Carminha pela amizade e pela alegria diária.

À toda equipe de professores do departamento de Botânica que, direta ou indiretamente, auxiliaram em diferentes etapas da minha formação acadêmica, especialmente ao Dr. Marcus Buckeridge, Dra. Marie Anne Van Sluys, Dra. Estela Maria Plastino, Dr. Antonio Salatino e Dra. Nanuza Luíza de Menezes.

Aos secretários do departamento de Botânica (Norberto, Carlos e Cesário) e da seção de Pós-graduação (Helder, Érika e Vera) por todo o auxílio nas questões burocráticas.

À Linácia e Suzy pela amizade e por proporcionarem limpeza e descontração no ambiente de trabalho.

Aos professores Dr. Hugo Cota-Sánchez e Dewey da University of Saskatchewan, e pesquisadoras Dra. Suzanne R. Abrams e Dra. Irina Zaharia (e respectiva equipe técnica) do NRC Plant Biotechnology Institute, por me receberem nas suas dependências e viabilizarem a análises de quantificação do perfil hormonal.

À FAPESP e ao CNPq pelo apoio financeiro na forma de bolsa de estudo e recursos que possibilitaram a realização desse trabalho.

E, finalmente, a todos os meus familiares que sempre me incentivaram e acreditaram em mim, especialmente aos meus pais e meu irmão, pelo amor, apoio e compreensão silenciosa durante o período de Doutorado.

Obrigada. 


\section{ÍNDICE}

I. Introdução

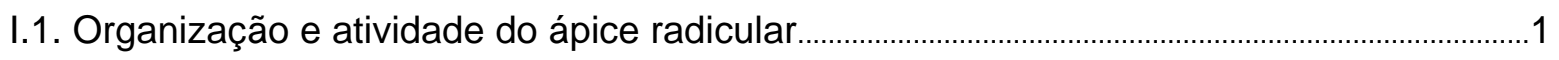

I.2. Sinalização no controle da atividade do meristema apical radicular (MAR) .........................4

I.2.1. Sinalização molecular no controle da atividade do MAR ........................................................4

I.2.2. Sinalização hormonal no controle da atividade do MAR ……………….................................5

I.2.3. Sinalização de moléculas mediadoras e moduladoras de sinais primários no

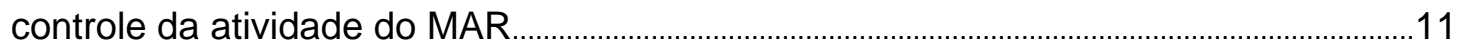

I.3. A conversão do MAR de Catasetum fimbriatum em gemas caulinares.........................15

II. Objetivos

III. Material e Métodos

III.1. Material vegetal e modo de obtenção

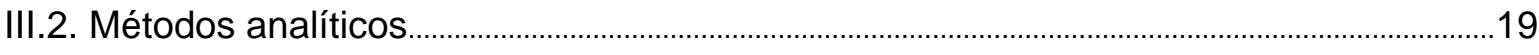

III.2.1. Acompanhamento do crescimento radicular de plantas in vitro.........................................19

III.2.2. Acompanhamento do desenvolvimento in vitro de ápices radiculares...........................20

III.2.3. Preparo de material para microscopia de varredura ...............................................................21

III.2.4. Método de preparo de material histológico para microscopia de luz .................................22

III.2.5. Preparo do material histológico para microscopia de fluorescência .....................................22

III.2.6. Preparo do meio de cultura para análises bioquímicas...............................................................23

III.2.7. Quantificação de amônio endógeno

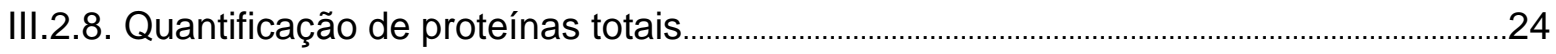

III.2.9. Quantificação da atividade in vivo da nitrato redutase ..........................................................24

III.2.10.Quantificação de citocininas endógenas por HPLC ............................................................25

III.2.11.Quantificação de citocininas, giberelinas e auxinas endógenas por RP-HPLC

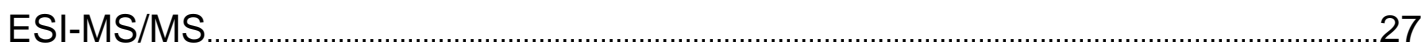

III.2.12. Quantificação de ácido abscísico por CG-EM-MS ..........................................................30

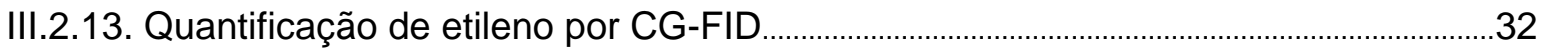

III.2.14. Quantificação de ascorbato e glutationa por HPLC ............................................................32

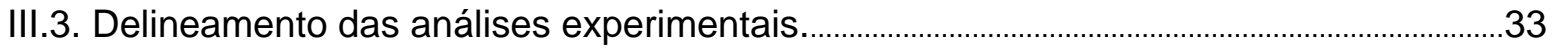

III.3.1. Análises das modificações morfológicas durante o ganho de competência para conversão do MAR em gemas............................................................................................................33

III.3.2. Análises das modificações bioquímicas durante o ganho de competência..................36 
III.3.3. Análises do papel das citocininas no ganho de competência................................................38

III.3.4. Análises do papel da auxina no ganho de competência........................................................40

III.3.5. Análises do papel do etileno no ganho de competência .........................................................44

III.3.6. Análises do conteúdo endógeno de giberelinas e do ácido abscísico durante o

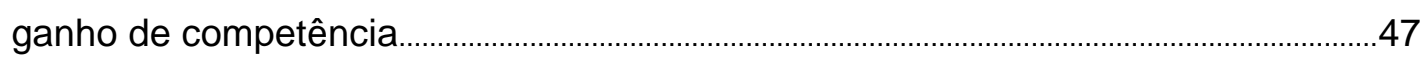

III.3.7. Análises do papel do estado redox no ganho de competência ..........................................48

III.3.8. Análises do papel do óxido nítrico no ganho de competência..........................................50

III.3.9. Análises do papel do cálcio citossólico no ganho de competência...................................51

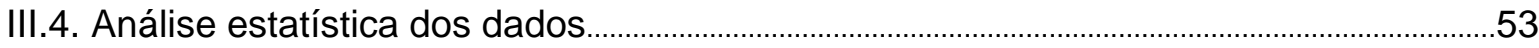

IV. Resultados

IV.1. Modificações no ápice radicular durante a aquisição de competência..................................54

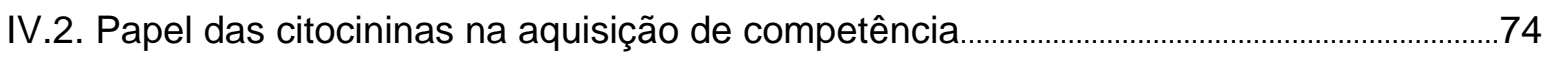

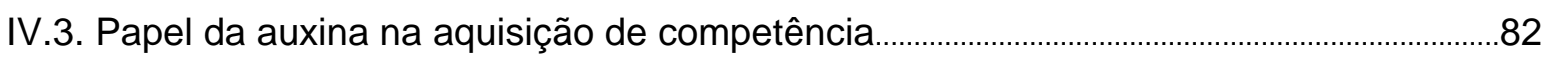

IV.4. Papel do etileno na aquisição de competência

IV.5. Teores de giberelinas e de ácido abscísico durante a aquisição de

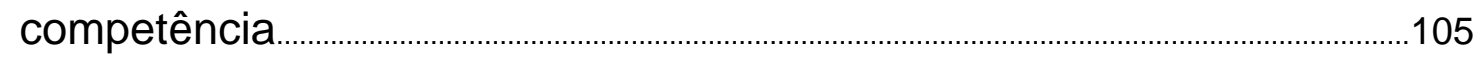

IV.6. Envolvimento do estado redox na aquisição de competência

IV.7. Importância do óxido nítrico e do cálcio citossólico na aquisição de competência....111

V. Discussão

VI. Conclusões

VII. Resumo

VIII. Abstract

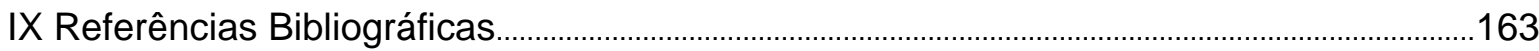




\section{LISTA DE ABREVIATURAS}

1-MCP:- 1-metilciclopropeno

ABA: ácido abscísico

AIA : ácido indolilacético

ASC: ascorbato

BA: benziladenina

CG: cromatografia a gás

cPTIO: 2-(4-carboxifenil)-4,4,5,5,-tetrametilimidazolina-1-oxil-3-óxido

$\mathrm{CQ}$ : centro quiescente

c-ZR: cis- zeatina ribosídica

DAF-2DA: 4,5 diaminofluoresceína diacetato

EGTA: ácido etilenoglicol-bis(-aminoetileter)-tetracético

GA: giberelinas

$\mathrm{GA}_{1}$ : giberelina 1

$\mathrm{GA}_{7}$ : giberelina 7

$\mathrm{GSH}$ - glutationa

HPLC: cromatografia líquida de alta resolução

IAA-Asp: ácido indolilacético-aspartato

iP: isopenteniladenina

iPR: isopenteniladenosina

KNOX: do Inglês "KNOTTED - like homeobox genes"

MAR: meristema apical radicular

MF: massa fresca

MS: matéria fresca

NO: óxido nítrico

NPA: ácido N-1-naftilftalâmico

PLT1 e PLT2: PLETORA1 e PLETORA2

ROS: espécies reativas de oxigênio

SNP: nitroprussiato de sódio

t-ZR: trans zeatina ribosídica

Z: zeatina

ZR: zeatina ribosídica 


\section{INTRODUÇÃO}

\section{I.1. Organização e atividade do ápice radicular}

O sistema radicular representa uma estrutura propícia para o estudo de fatores que controlam a plasticidade na organização celular durante o desenvolvimento vegetal (MALAMY, 2005), uma vez que as raízes possuem simetria radial e são compostas por células organizadas em fileiras e regiões ligeiramente bem definidas (BLOOM et al., 2003). A organização e a estrutura da raiz são determinadas pela somatória das atividades integradas das populações de células que compõem o ápice radicular (JIANG e FELDMAN, 2003).

O ápice de uma raiz em crescimento apresenta regiões relativamente bem definidas, como a coifa, meristema fundamental, região de alongamento (muito diminuta na maioria das raízes) e, finalmente, uma região de maturação celular que se sobrepõe parcialmente à zona de alongamento (BIRNBAUM e BENFEY, 2004; JIANG e FELDMAN, 2005). Nas Angiospermas o crescimento radicular é mantido e regulado através da atividade do meristema apical radicular (MAR). Um balanço entre a formação de novas células meristemáticas e a transição para a diferenciação celular regula a atividade do MAR, permitindo a sua manutenção (SABLOWSKI et al., 2007).

A localização de cada tecido radicular pode variar de acordo com o seu crescimento, possibilitando que a raiz mude as relações espaciais entre divisão, alongamento e eventos de diferenciação celular. As divisões celulares no meristema ocorrem na direção da base radicular para formar células que se diferenciarão em tecidos da raiz funcional, e na direção do ápice radicular para formar e manter a coifa. Na fronteira entre o corpo da raiz e a coifa encontra-se uma região, denominada de centro quiescente (CQ), composta de poucas células que se dividem lentamente (BLOOM et al., 2003).

O CQ é uma característica onipresente no MAR de todas as Angiospermas, pelo menos em uma parte da ontogenia (JIANG e FELDMAN, 2005). Um dos papéis atribuídos ao 
CQ é a manutenção de células iniciais estruturais (fonte de todas as demais células no corpo da planta) em um estado pouco diferenciado (CASSON e LINDSEY, 2003). Apesar do CQ ter sido foco de muitas abordagens nos últimos anos (AIDA et al. 2004, HAECKER et al., 2004; UEDA et al., 2004; JIANG e FELDMAN, 2005), seu papel no desenvolvimento radicular ainda continua pouco compreendido. No entanto, está suficientemente bem estabelecido que o CQ exerce um papel central no desenvolvimento das raízes, e que ele atua como um elemento integrador em muitos processos e eventos indispensáveis ao estabelecimento e manutenção do MAR (JIANG e FELDMAN 2005; SHISHKOVA et al., 2008).

O MAR da grande maioria das raízes em fase de crescimento possui células iniciais dispostas de maneira muito bem definida, sendo que as células localizadas ao redor do CQ (onde se encontram as iniciais estruturais) apresentam uma elevada taxa de divisão celular e são chamadas de iniciais funcionais do MAR (BARLOW, 1997). Recentemente, alguns autores vêm nomeando as células iniciais funcionais de células-tronco (tradução do Inglês "stem cells"), baseando-se no fato de que as iniciais funcionais meristemáticas e as célulastronco nos animais possuem características em comum que as possibilitam se auto-perpetuar por meio de sua proliferação, e também dar origem a novos tecidos durante a vida desses organismos (IVANOV, 2004; DINNENY e BENFEY, 2008). No entanto, nesse trabalho será adotado o termo tradicional, ou seja, células iniciais funcionais do MAR. Dentre essas células estão as células iniciais vasculares (originam o procâmbio / cilindro vascular), as iniciais do tecido fundamental (originam o córtex e a endoderme), as iniciais da columela (originam a columela, o tecido central da coifa), e as iniciais das células laterais da coifa e da protoderme (epiderme imatura em divisão) (HANSTEIN, 1868; DOLAN et al. 1993; ZHU et al. 1998).

Ao contrário do que se postula, estudos têm mostrado que as raízes de muitas espécies não possuem a capacidade de crescerem indefinidamente; apresentando, na verdade, crescimento determinado (CHAPMAN et al. 2003). Em muitas espécies tem-se verificado que o MAR é geneticamente programado para parar de produzir novas células em 
um estágio específico do desenvolvimento, sendo que nesse caso o meristema é classificado como um MAR determinado (SABLOWSKI et al., 2007). Uma curva típica de crescimento radicular determinado possui três fases: uma fase inicial de alongamento acelerado, uma fase de crescimento constante e uma fase de desaceleração, levando ao término do alongamento. O momento em que o tamanho determinado é alcançado varia de acordo com a espécie e os fatores ambientais. Quando raízes com crescimento determinado alcançam seu tamanho máximo, verificam-se modificações conspícuas na estrutura de seu MAR, inclusive a antiga organização fechada do meristema apical radicular torna-se menos precisa, passando a apresentar, comumente, uma organização aberta (CHAPMAN et al., 2003).

O MAR pode possuir vários tipos de organização das células que o compõe, sendo que os dois tipos básicos de organização são, segundo von GUTTENBERG (1968), o MAR do tipo fechado e o tipo aberto. O MAR do tipo fechado possui um padrão organizado de disposição das células, sendo possível discernir qual inicial meristemática originou cada fileira de células em estágios mais avançados do desenvolvimento. O MAR do tipo aberto, por sua vez, não possui esse tipo de organização, compartilhando iniciais meristemáticas entre as fileiras de células (BAUM et al., 2002). Ainda há uma terceira classificação menos relatada que é o MAR do tipo intermediário-aberto, a qual se apresenta com perda relativa da organização das células centrais da coifa e as do CQ, com a ausência de uma clara delimitação feita pela protoderme entre esses dois conjuntos de células (GROOT et al., 2001).

Dessa forma, a diferença entre crescimento indeterminado e determinado em plantas consiste na presença ou ausência de um meristema ativo em um órgão completamente desenvolvido. O crescimento radicular determinado implica que o MAR torna-se extinto e, como conseqüência, todas as células no ápice radicular tornam-se diferenciadas. Esse tipo de crescimento é freqüentemente encontrado em diferentes grupos de angiospermas e parece ter evoluído como uma adaptação do desenvolvimento radicular à deficiência hídrica ou ao baixo conteúdo de minerais no solo (SHISHKOVA et al., 2008). 
Os sinais que levam a raiz a atingir o crescimento determinado são ainda pouco conhecidos, e têm sido foco de muitos esforços nos últimos anos. As descobertas a cerca dos mecanismos fisiológicos de controle sobre esse evento envolvem tanto elementos de controle gênico quanto de sinalização hormonal. Uma hipótese geral que busca explicar tal fenômeno propõe que em meristemas velhos ocorra uma diminuição de certos efeitos inibitórios das células do CQ sobre a diferenciação das iniciais funcionais vizinhas (van den BERG et al., 1997), perturbando, dessa forma, o balanço entre as iniciais estruturais do CQ e as iniciais funcionais do meristema fundamental, estabelecendo o crescimento determinado radicular (JIANG e FELDMAN, 2005).

\section{I.2. Sinalização no controle da atividade do meristema apical radicular (MAR)}

O desenvolvimento das plantas necessecita de um controle fino das populações de células iniciais nos meristemas, bem como da especificação apropriada dos destinos celulares (NAKAJIMA e BENFEY, 2002). Recentemente, estudos moleculares, genéticos e fisiológicos dos processos de diferenciação e organização celular em meristemas apicais começaram a revelar seus participantes essenciais, e a delinear os papéis que os mesmos desempenham no controle desses tecidos (CASTELLANO e SABLOWSKI, 2005; VEIT, 2006).

\section{I.2.1. Sinalização molecular no controle da atividade do MAR}

Embora estejam ocorrendo avanços consideráveis acerca do controle molecular das células meristemáticas, ainda não está claro como a manutenção e a proliferação das células

iniciais são controladas em relação aos processos de organogênese e diferenciação, 
principalmente no MAR (VEIT, 2004; CASTELLANO e SABLOWSKI, 2005; SARKAR et al., 2007).

Um dos participantes do controle das células iniciais no MAR que tem ganhado relevância crescente é o fator de transcrição WOX5 (do Inglês "WWUSCHEL-related homeobox 5"), o qual é expresso no CQ, e cuja perda de função nas células iniciais causa a diferenciação terminal deste meristema (SARKAR et al., 2007). A expressão de outros genes como PLETORA (PLT), SCARECROW e SHORT-ROOT, também têm se revelado necessária para a manutenção da organização normal tanto do meristema fundamental quanto do CQ (AIDA, 2004; Di LAURENZIO et al., 1996; HELARIUTTA et al., 2000; SABATINI et al., 2003).

Além dos genes supracitados, mutações em plantas de Arabidopsis thaliana que ocasionam o crescimento determinado precocemente, têm ajudado na compreensão de alguns pontos do controle genético do desenvolvimento do MAR, como é o caso dos mutantes axr6 (HOBBIE et al., 2000), monopterous (HARDTKE e BERLETH, 1998), rfc3 (HORIGUCHI et al., 2003), obe1/obe2 (SAIGA et al, 2008), root meristemless (CHENG et al., 1995), entre outros.

Dessa forma, nos últimos anos vem ocorrendo um grande aumento na compreensão dos eventos moleculares envolvidos na especificação e organização celular em raízes devido, principal e quase unicamente, a pesquisas concentradas na planta modelo $A$. thaliana. No entanto, evidências da interligação entre os genes participantes na organização radicular e as respostas hormonais começaram a surgir bem mais recentemente (PEREZ-PEREZ, 2007), sendo dessa forma, pouco compreendidas mesmo neste modelo.

\section{I.2.2. Sinalização hormonal no controle da atividade do MAR}

Os hormônios vegetais desempenham um papel crucial no metabolismo, crescimento e desenvolvimento das plantas atuando como mensageiros químicos primários (VOGLER e 
KUHLEMEIER, 2003). Diversos sinais hormonais participam do controle sobre o posicionamento e o número de células nos meristemas (CASTELLANO e SABLOWSKI, 2005), sendo que praticamente todos os hormônios vegetais conhecidos até o momento podem afetar, individualmente, a organização do sistema radicular, não obstante a existência de evidências indicativas da ocorrência de interações entre essas substâncias entre si na regulação do crescimento de raízes (OSMONT et al., 2007).

Estudos recentes de biologia molecular têm corroborado, de forma consistente, o papel chave desempenhado pelos hormônios na manutenção do crescimento de raízes primárias (OSMONT et al., 2007). O conjunto de informações existentes nessa temática deixa suficientemente claro que as auxinas ocupam posição particularmente importante no controle da organização do sistema radicular, sendo essa classe hormonal considerada a protagonista principal no crescimento e desenvolvimento das raízes (CASIMIRO et al., 2001; 2003; JIANG e FELDMAN, 2003; SABATINI et al., 1999; FRIML et al., 2002; OSMONT et al., 2007).

A importância das auxinas para o crescimento radicular foi verificado, entre outras evidências, por meio de análises de mutantes que apresentaram sistemas radiculares muito curtos e pouco ramificados, os quais coincidiram com teores relativamente diminuídos dessa classe hormonal ou deficiência na sua sinalização (CELENZA et al., 1995). Há também propostas de que o estabelecimento do crescimento determinado radicular ocorra como conseqüência de uma diminuição de auxina nas células meristemáticas (FRIML et al., 2004).

SABATINI e colaboradores (1999) verificaram que a auxina é assimetricamente distribuída no ápice radicular, com uma concentração aparentemente mais elevada (máximo de auxina) na região que abrange o CQ. Evidências consideráveis têm sido apresentadas enfatizando a importância da presença desse máximo de auxina na organização e estabelecimento do CQ (KERK e FELDMAN, 1995; KERK et al., 2000; JIANG e FELDMAN, 2003). Atualmente sabe-se que a região ocupada pelo máximo de auxina coincide com a expressão dos genes PLT1 e PLT2, os quais representam fatores de transcrição essenciais 
na especificação do CQ e na atividade das células iniciais funcionais no MAR de $A$. thaliana. Além da expressão de PLT ocorrer na mesma região ocupada pelo máximo de auxina no ápice radicular, ela também depende da sinalização dada por essa classe hormonal (AIDA et al., 2004).

A interação entre auxina e o etileno no controle do desenvolvimento radicular tem adquirido evidência, uma vez que diversos mutantes de $A$. thaliana deficientes na sinalização de auxina mostraram-se também insensíveis ao etileno, indicando que este deveria atuar como um hormônio mediador em algumas respostas induzidas por auxina nas raízes (MULLER et al. , 1998; LUSCHNIG et al., 1998; WILSON et al., 1990). A interação entre esses dois tipos hormonais também tem sido demonstrada por estudos fisiológicos, uma vez que o etileno pode inibir o transporte polar de auxina (BURG e BURG, 1967; MORGAN e GAUSMAN, 1966; SUTTLE, 1988) e estimular a síntese de ácido indolilacético (STEPANOVA et al., 2005). Por outro lado, os efeitos da auxina podem ser mediados pelo etileno (PRAYITNO et al., 2006). Tais estudos sugerem que alguns efeitos do etileno ocorram via regulação do transporte polar de auxina e esse último, por sua vez, necessite freqüentemente da sinalização dada pelo etileno (KASKA et al., 1999). Segundo CASSON e LINDSEY (2003), a habilidade da auxina em induzir a biossíntese de etileno, e este de inibir o transporte de auxina, sugeriria um mecanismo de controle do crescimento radicular por feedback entre essas vias de sinalização.

Nessa linha de raciocínio, verificou-se que concentrações moderadas de etileno mostraram-se inibitórias ao crescimento radicular tanto de milho quanto de $A$. thaliana, possivelmente, devido ao desequilíbrio na organização celular no CQ e na coifa. Além disso, certos mutantes que apresentaram respostas aumentadas na sinalização do etileno também tiveram o crescimento radicular diminuído e deficiência na organização do MAR. Essas deficiências foram superadas quando se utilizou estratégias genéticas ou com aplicação de substâncias moduladoras da sinalização de etileno no sentido de inibi-la, resultando na 
retomada do desenvolvimento normal das raízes de tais mutantes (PONCE et al., 2005). Essas descobertas sugerem que a função correta do MAR requeira um controle fino sobre respostas ao etileno no ápice das raízes.

Ao contrário do etileno, que é freqüentemente relacionado à promoção do envelhecimento e senescência de tecidos vegetais (van LOON e GLICK, 2004), as citocininas são extensivamente conhecidas como uma classe hormonal envolvida em processos de inibição da senescência das plantas (ANANIEVA et al., 2004). No entanto, assim como o etileno, as citocininas, em conjunto com as auxinas, também podem exercer muitos papéis fisiológicos-chaves.

A atuação conjunta de citocininas e auxinas ocorre, por exemplo, na estimulação da proliferação celular, no estabelecimento de organogênese in vitro (MILLER et al., 1956), no controle do ciclo celular (FRANCIS e SORRELL, 2001), entre outros eventos. Os teores endógenos elevados de citocininas são freqüentemente relacionados com o desenvolvimento de gemas laterais, iniciadas a partir da indução de divisões celulares (BOLLMARK et al., 1995). Segundo CHOW e McCOURT (2004), o acúmulo dessa classe de hormônios coincide com a formação de meristemas e gemas adventícias, e com a expressão ectópica de genes relacionados com a identidade do meristema apical caulinar, como é o caso dos genes da família KNOX (do Inglês "KNOTTED - like homeobox genes").

De maneira coerente ao acima exposto, as citocininas regulam as divisões celulares por meio do controle sobre a transição da fase G1 para S, e da fase G2 para M do ciclo celular (del POZO et al., 2005). Segundo WERNER et al. (2003), essa classe hormonal atuaria como um regulador negativo do crescimento de raízes, controlando a saída das células do ciclo de divisões no MAR para a diferenciação. Ainda sob esta perspectiva, as citocininas parecem desempenhar um papel importante no controle da atividade do MAR, à medida que se verificou um aumento no crescimento da raiz primária de plantas de $A$. 
thaliana deficientes tanto na biossíntese (WERNER et. al., 2003) quanto na sinalização (RIEFLER et al., 2006) dessa classe hormonal.

Mesmo com o conhecimento de que tecidos e órgãos com capacidade de divisão celular (tais como folhas jovens, ápices caulinares e sementes imaturas) também possuam capacidade de produzir citocininas de maneira localizada, o ápice radicular ainda é considerado o principal local de biossíntese dessa classe hormonal (MIYAWAKI et al., 2004; Nordström et al., 2004; LETHAM, 1994). A biossíntese de giberelinas (GA) também já foi detectada em ápices radiculares de diferentes espécies, sendo que a sinalização dessa classe hormonal parece ser necessária para o crescimento da raiz primária (FU e HARBERD, 2003; KANEKO et al., 2003).

Apesar das giberelinas terem o seu papel bem estabelecido no alongamento caulinar, a sua contribuição no crescimento radicular permaneceu totalmente obscura até recentemente (PEREZ-PEREZ, 2007). Alguns dados obtidos com mutantes de $A$. thaliana forneceram indícios importantes sobre a participação das giberelinas no desenvolvimento dos ápices radiculares, uma vez que foi verificada a presença de raízes mais curtas em mutantes deficientes na produção dessa classe hormonal (FU e HARBERD, 2003).

Complementarmente, verificou-se que auxinas são necessárias para o controle do crescimento radicular mediado por giberelinas, uma vez que a inibição do transporte de auxina provocou o atraso na sinalização desencadeada por GA, o qual participaria na estimulação do crescimento radicular. Essas conclusões foram baseadas em observações que indicaram que o ápice caulinar exercia um controle de longa distância sobre as raízes por meio da auxina, cuja ação dar-se-ia pela desestabilização de proteínas DELLA (repressoras do crescimento radicular) mediada por giberelinas (FU e HARBERD, 2003). Ressalta-se que as giberelinas opõem-se à ação das proteínas DELLA por desestabilizá-las, fazendo com que a concentração desses repressores da sinalização de GA seja reduzida e, 
conseqüentemente, sejam diminuídos os efeitos inibitórios sobre o crescimento causados por estas proteínas (GUBLER et al., 2002).

O ácido abscísico (ABA) é um hormônio vegetal também freqüentemente relacionado à ação integrada com auxina no processo de organogênese radicular, uma vez que ele parece exercer uma ação modulatória sobre o transporte polar de auxina, afetando eventos mitóticos no MAR e inibindo o desenvolvimento de raízes laterais (SWARUP et al., 2002). No entanto, até há pouco tempo atrás seus efeitos sobre a regulação da atividade meristemática e do destino celular dentro dos meristemas eram freqüentemente relacionados com a mediação de respostas a estresses ambientais, principalmente o estresse hídrico (LIANG et al. 2007). Recentemente, análises de mutantes de Medicago truncatula deficientes em ABA indicaram que esse hormônio participaria do controle do crescimento radicular, mesmo na ausência de estresse hídrico (KOORNNEEF et al., 1982; DEAK E MALAMY, 2005), dando mais subsídios à compreensão de seu papel na regulação da divisão celular no MAR (BROCARD-GIFFORD et al., 2004).

Esses mutantes denominados de latd (do Inglês "lateral root organ defective") apresentaram deficiência nos meristemas das raízes primárias e laterais, bem como naqueles dos nódulos simbióticos desta leguminosa (BRIGHT et al., 2005). A raiz primária cresceu lentamente, tinha o ápice radicular bastante alterado morfologicamente e o crescimento cessou precocemente, indicando que o MAR foi extinto nessa fase. A aplicação de ABA nesses mutantes restabeleceu o fenótipo da raiz, bem como a organização e a função do meristema primário e dos laterais, proporcionando também a formação da coifa (LIANG et al., 2007). Esses estudos indicaram que ABA pode estar envolvido na manutenção do MAR, bem como na transição do crescimento radicular do tipo indeterminado para o tipo determinado (SHISHKOVA et al., 2008). 


\section{l.2.3. Sinalização de moléculas mediadoras e moduladoras de sinais primários no controle da atividade do MAR}

Pesquisas recentes baseadas no estudo da sinalização da embriogênese em algumas espécies vegetais vêm apontando para um possível envolvimento de espécies reativas de oxigênio (ROS, do Inglês "reactive oxygen species") e de radicais livres como importantes elementos sinalizadores durante o desenvolvimento vegetal, no entanto, ainda não está claro como esses elementos estariam envolvidos com a sinalização hormonal (BEVERIDGE et al., 2007).

Normalmente, as respostas ao estresse influenciam o conteúdo de ROS e de outras moléculas importantes no controle do balanço redox das células (BELMONTE et al., 2005), sendo que as vias de transdução de sinais que são ligadas ao aumento de ROS freqüentemente incluem mobilização de cálcio citossólico, fosforilação de proteínas e expressão gênica (NEILL et al, 2002). Dessa forma, o balanço redox celular é determinado pela contribuição líquida dos diferentes ROS e pares redox, sendo que em sistemas biológicos os pares redox mais importantes e abundantes são representados pelas formas reduzidas e oxidadas de glutationa e ascorbato (CÓRDOBA-PEDREGOSA et al., 2003).

A forma reduzida de glutationa (GSH) possui, além do papel antioxidante, outras importantes funções no desenvolvimento vegetal, tais como a regulação do crescimento, desenvolvimento e expressão gênica (NOCTOR e FOYER, 1998; MAY et al., 1998). Há também várias evidências que apontam para um papel específico da forma reduzida de ascorbato (ASC) na organização, crescimento e desenvolvimento radicular (ARRIGONI, 1994; KERK e FELDMAN, 1995; De TULLIO et al.,1999; ARRIGONI e De TULLIO, 2000), tendo forte relação com a glutationa nessas respostas (FRICKER et al., 2000; SÁNCHEZFERNÁNDEZ et al., 1997; JIANG et al., 2003). 
Um bom exemplo da importância da GSH no desenvolvimento radicular é dado por plantas mutantes de $A$. thaliana para o gene ROOT MERISTEMLESS, o qual codifica a primeira enzima da biossíntese de GSH. A mutação nesse gene leva a uma redução dos teores adequados de GSH no ápice radicular, impossibilitando as plantas de formar um meristema apical radicular pós-embrionário. No entanto, as características dos mutantes podem ser revertidas, com a formação de um MAR organizado, por meio de tratamentos com GSH (VERNOUX et al., 2000).

GSH está relacionada à proliferação celular tanto em células vegetais quanto em animais, sendo que as formas oxidadas de glutationa e ascorbato atrasam a progressão do ciclo celular, ao passo que as suas formas reduzidas mostraram-se relacionadas à ativação de divisões celulares no MAR de milho (JIANG E FELDMAN, 2005). Além disso, postulou-se que a auxina afete o ciclo celular no centro quiescente por meio de mudanças no redox de suas células (JIANG et al., 2003). Essa regulação ocorreria por meio da modulação do estado redox localmente, sendo que o ácido ascórbico poderia atuar, por meio da ácido ascorbico oxidase, como um possível intermediário entre a auxina e a manutenção do CQ (KERK e FELDMAN, 1995; KERK et al., 2000).

O óxido nítrico (NO) é um radical livre que e há poucos anos foi descoberto como molécula sinalizadora em plantas (LAMATTINA et al., 2003). É, portanto, compreensível que suas funções nos organismos vegetais sejam ainda relativamente pouco conhecidas, não obstante já se saiba que atue de forma regulatória em uma gama considerável de processos relacionados ao crescimento e desenvolvimento das plantas (WILSON et al., 2008).

Recentemente, tem-se verificado um número crescente de estudos que indicam o envolvimento do NO em diferentes eventos fisiológicos, como no crescimento caulinar (ZHANG et al., 2003; AN et al., 2005), divisão celular (OTVOS et al., 2005), xilogênese (GABALDON et al., 2005), interação planta-patógeno (CREUS et al., 2005), entre outros. Sabe-se, por exemplo, que esse radical livre em baixas concentrações pode retardar a 
senescência de órgãos vegetais e estimular o crescimento radicular (BELLIGNI e LAMATTINA, 2001).

Alguns trabalhos têm indicado o NO como um importante mediador de moléculas sinalizadoras primárias (BELLIGNI e LAMATTINA, 2001; PAGNUSSAT et al., 2003); ele parece interagir de maneira estreita com os sistemas de ação dos hormônios vegetais, sendo considerado muitas vezes como um mensageiro secundário dos sinais hormonais. De fato, estudos têm demonstrado que o NO media a abertura de estômatos induzida por ABA e interfere na sinalização do etileno durante a maturação e senescência de tecidos vegetais (LAMATTINA et al., 2003). Outros dados sugerem que o NO esteja envolvido com a sinalização de citocininas de maneira direta (TUN et al., 2008) ou indireta (Ramanov et al., 2008). As auxinas podem estimular a produção de NO em várias espécies de plantas (PAGNUSSAT et al., 2002; NEILL et al., 2002), sendo que o envolvimento do NO como uma molécula sinalizadora na cascata de sinalização induzida por auxina em muitos processos de desenvolvimento radicular está sendo objeto de grande interesse (PAGNUSSAT et al., 2002; 2003; Correa-Aragunde et al., 2004; 2006; HU et al., 2005).

No entanto, ainda há relativamente poucos estudos que analisaram a participação do NO nos processos de organogênese vegetal como um todo (LAMATTINA et al., 2003). Um dos primeiros relatos do envolvimento desse radical livre em processos organogênicos foi evidenciado em explantes de Cucumis sativus, cuja formação de raízes adventíceas apresentou uma dependência substancial da produção endógena de NO (PAGNUSSAT et al., 2002). Ainda conforme esses autores, a aplicação de ácido indolilacético (AIA) resultou em um aumento dos teores endógenos de NO na região basal do hipocótilo, onde normalmente se formam os novos meristemas radiculares, evidenciando a atuação desse gás como mensageiro secundário da auxina na rizogênese adventícea (PAGNUSSAT et al., 2002; 2003). 
O cálcio citossólico também tem sido considerado como um importante mensageiro secundário na transmissão de sinais em nível celular nas plantas (TREWAVAS, 1999; RUDD e FRANKLIN-TONG, 2001). Sua ação normalmente é exercida por meio de mudanças em sua concentração citossólica em resposta a diferentes estímulos, sendo que cada estímulo parece desencadear variações com características espaciais e temporais específicas (BUSH, 1995; WHITE e BROADLEY, 2003).

A homeostase celular dos íons cálcio é normalmente mantida em níveis muito reduzidos por meio de um conjunto de bombas transportadoras de cálcio associadas às membranas dos compartimentos celulares, por transportadores secundários e por canais de íons (HEPLER e WAYNE, 1985; BUSH, 1995). As mudanças na concentração de cálcio citossólico induzidas pelos diferentes estímulos podem ser transitórias, constantes ou oscilatórias, e o tempo necessário para a resposta completa varia de alguns segundos até muitas horas (BUSH, 1995; MALHÓ et al., 2006).

Dessa forma, diferentes sinais ambientais e hormonais mobilizam, de modo específico, cálcio para o citossol (ANIL e RAO, 2001). A abertura e fechamento estomático é o modelo de estudo no qual se encontra melhor estabelecido o envolvimento do cálcio citossólico como mediador da sinalização hormonal. De acordo com o atual conhecimento sobre o assunto, ABA induz o fechamento estomático por meio de um sistema de sinalização que envolve elevações transientes e localizadas na concentração de cálcio citossólico nas células-guarda (McAINSH et al., 1990; 1992; SCHROEDER e HAGIWARA, 1990; GILROY et al., 1991; Allan et al., 1994; Grabov e Blatt, 1998; Allen et al., 1999).

Outros trabalhos também indicam a participação do cálcio como mediador de respostas induzidas por citocininas (SAUNDERS, 1990; SAUNDERS et al., 1992; BRAULT e MALDINEY, 1999; BARWE et al., 2001a; 2001b), incluindo a indução da formação de gemas vegetativas em explantes isolados de regiões radiculares maduras de Albizzia julibrissin (HOSSEINI-NASR e RASHID, 2002). Alguns relatos apontam para a participação do cálcio 
citossólico durante o processo de embriogênese somática em cenoura por meio de elevações na sua concentração nas fases mais avançadas desse processo, sendo que esse aumento parece estar relacionado com a sinalização dada pela a auxina (TIMMERS et al., 1996). Outros trabalhos também demonstraram que tratamentos com auxina levam ao aumento de cálcio citossólico (ETTLINGER e LEHLE, 1988), sendo que em poucos casos verificou-se uma diminuição de cálcio após o tratamento com auxina (DAS et al., 1987; TRETYN et al. , 1991).

A manutenção de teores elevados de cálcio citossólico por períodos prolongados pode inibir o transporte célula-a-célula nas plantas por meio do fechamento dos plasmodesmas (TUCKER, 1990). Esse isolamento fisiológico causado pela sinalização demorada de altos teores de cálcio citossólico parece ser um importante sinal inicial na embriogênese somática. Verificou-se que as citocininas podem também causar esse tipo de aumento demorado na concentração de cálcio citossólico, neste caso, estimulando o desencadeamento da embriogênese (FUJIMURA e KOMAMINE, 1979; LI e NEUMANN, 1985).

\section{I.3. A conversão do MAR de Catasetum fimbriatum em gemas caulinares}

A possibilidade de transformação de um meristema radicular em um meristema caulinar tem por muito tempo fascinado gerações de botânicos. Dentre as angiospermas, este evento só foi relatado para algumas poucas espécies da família Araceae (PETERSON, 1975), para Neottia nidus-avis, uma orquídea terrestre européia (CHAMPAGNAT, 1971), e mais recentemente para algumas orquídeas epífitas pertencentes ao grupo das Catasetineae (KERBAUY, 1984; KRAUS e KERBAUY, 1992; COLLI e KERBAUY, 1993).

Nos últimos vinte anos esse evento organogênico vem sendo estudado no Laboratório de Fisiologia Vegetal do IBUSP com o gênero Catasetum, mais especialmente em Catasetum fimbriatum. Segmentos de ápices radiculares isolados desta planta, medindo entre 2 e $20 \mathrm{~mm}$ 
de comprimento, quando cultivados em meio de cultura básico, originam diretamente gemas vegetativas em região apical bem definida e num período bastante breve, se comparado ao de outros modelos vegetais mais conhecidos (KERBAUY, 1984). A conversão ocorre por meio de uma provável reprogramação gênica refletida nos eventos bioquímicos subseqüentes de transmissão de sinais e diferenciação celular (KERBAUY, 1999). Segundo o trabalho realizado por KRAUS e MONTEIRO (1989) com segmentos de ápices radiculares de Catasetum pileatum, esse evento teria início na região que corresponde ao centro quiescente dos explantes. Tratamentos com citocininas e etileno mostraram-se promotores à conversão dos ápices radiculares em gemas caulinares (COLLI e KERBAUY, 1993). PERES e KERBAUY (1999) observaram um acúmulo de cerca de 38 vezes nos teores de citocininas endógenas após 10 dias do isolamento dos explantes. Além disso, SUZUKI et al. (2004) mostraram que a conversão pode ocorrer em ápices radiculares cultivados por longo período no escuro, mesmo se ligados à planta-mãe; nesse caso, coincidindo com um acúmulo substancial de citocininas endógenas na planta como um todo.

Conforme observado em estudos histológicos de conversão radicular realizados por KRAUS e MONTEIRO (1989) em Catasetum pileatum, os eventos relacionados ao desencadeamento desse processo organogênico parecem ocorrer precocemente, por volta de 48 horas após isolamento dos ápices radiculares da planta-mãe. No entanto, devido à complexidade deste evento raro permanecem ainda pouco compreendidos quais os sinais que controlariam a competência para a conversão do MAR de C. fimbriatum em gemas caulinares. 


\section{II.OBJETIVOS}

O objetivo desse estudo foi o de investigar as modificações morfológicas e os eventos de sinalização envolvidos na aquisição de competência necessária à conversão do meristema apical radicular (MAR) de Catasetum fimbriatum em gemas caulinares. Para tanto, foram consideradas as seguintes abordagens experimentais:

1) Análise das alterações morfológicas e dos ápices radiculares de $C$. fimbriatum durante o envelhecimento da raiz - período em que ocorre a aquisição de competência para conversão do MAR em gemas caulinares;

2) Análise das variações nos teores endógenos de citocininas, auxinas, giberelinas, etileno e ácido abscísico durante o envelhecimento radicular;

3) Análise dos efeitos da aplicação de substâncias moduladoras dos teores de auxinas, citocininas e etileno sobre a aquisição de competência do MAR;

4) Análise de um possível papel sinalizador do balaço redox, óxido nítrico e cálcio citossólico na aquisição de competência do MAR durante o envelhecimento;

5) Análise das alterações morfológicas do ápice radicular concomitantes às variações nos teores endógenos de citocininas durante as primeiras horas após o isolamento de explantes competentes para conversão em gemas caulinares. 


\section{MATERIAL E MÉTODOS}

\section{III.1. Material vegetal e modo de obtenção}

Todo o material utilizado foi obtido de plantas de Catasetum fimbriatum Morren Lindl. (Orchidaceae) micropropagadas in vitro (clone CFC1), clone esse que vem sendo mantido no Laboratório de Fisiologia Vegetal da Universidade de São Paulo desde 1993, por meio da técnica estabelecida por KERBAUY et al. (1995).

Para tanto, as plantas foram incubadas sob condições de escuro no meio de VACIN e WENT (1949), modificado pela substituição de citrato de ferro por Fe-EDTA, adição dos micronutrientes de MURASHIGE e SKOOG (1962), 100 mg/L de mio-inositol, 1,0g/L de peptona de soja e 0,1mg/L de tiamina, e 20g/L de sacarose. A necessária geleificação foi obtida com 2g/L de Phytagel ${ }^{\circledR}$. Sob tais condições, os caules de C. fimbriatum apresentaram crescimento estiolado contínuo (Figura 1A), formando entrenós alongados e nós com uma gema lateral cada (Figura 1B).

Para a obtenção das plantas experimentais e de plantas fornecedoras de ápices radiculares, secionaram-se os segmentos nodais das plantas estioladas, os quais foram inoculados na presença de luz (Figura 1C). O meio de cultura utilizado para o crescimento das plantas foi o de VACIN e WENT (1949) modificado pela substituição de citrato de ferro por Fe-EDTA e pela adição dos micronutrientes de MURASHIGE e SKOOG (1962), suplementado com $1 \mathrm{~g} / \mathrm{L}$ de carvão ativado e $20 \mathrm{~g} / \mathrm{L}$ de sacarose, utilizando-se $7 \mathrm{~g} / \mathrm{L}$ de ágar para geleificação. $\mathrm{O}$ pH de todos os meios de cultura utilizados nesse trabalho foi ajustado para $5,8 \mathrm{com} \mathrm{KOH}$, e a esterilização obtida em autoclave a $120^{\circ} \mathrm{C}$ durante 15 minutos.

Dependendo do experimento, as plantas foram crescidas por diferentes períodos (30, 60, 120 ou 240 dias, contados a partir do momento da inoculação dos segmentos nodais estiolados no meio de crescimento) sob $50 \mu$ moles. $\mathrm{m}^{-2} \cdot \mathrm{s}^{-1}$ de intensidade luminosa, 16 horas 
de fotoperíodo e temperatura de $26 \pm 1^{\circ} \mathrm{C}$ (Figura 1D). Foram utilizadas, de acordo com cada objetivo experimental plantas intactas ou ápices radiculares, os quais foram isolados de plantas obtidas segundo a descrição feita acima (Figura 1E) e consistiram de ápices radiculares com cerca de $5 \mathrm{~mm}$ de comprimento cada (Figura 1F).

A

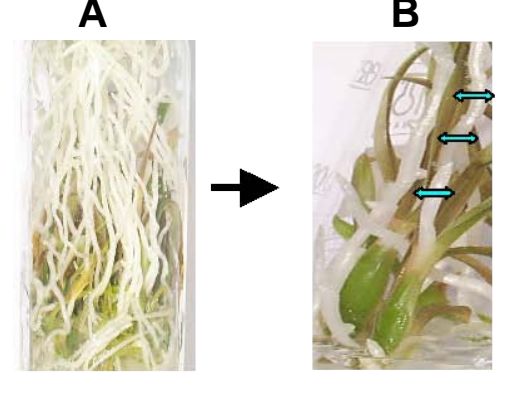

C

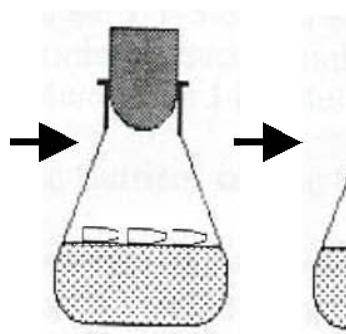

D

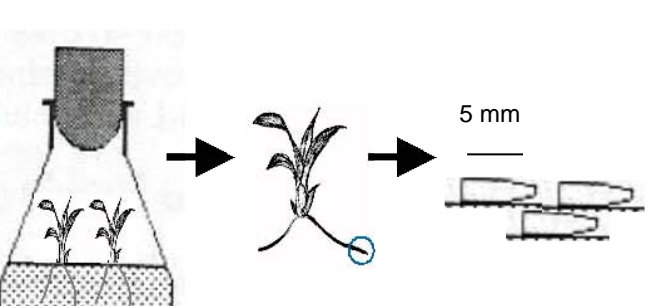

Figura 1: Esquema da obtenção do material vegetal de C. fimbriatum: (A) plantas crescidas no escuro; (B) segmentos nodais com uma gema lateral cada; $(C)$ incubação dos segmentos nodais em meio de crescimento; (D) desenvolvimento de plantas por 30,60, 120 ou 240 dias (plantas intactas utilizadas em alguns experimentos); (E) isolamento dos ápices radiculares; (F) ápices radiculares isolados com cerca de $5 \mathrm{~mm}$ (material experimental para algumas análises).

\section{III.2. Métodos analíticos}

\section{III.2.1. Acompanhamento do crescimento radicular de plantas in vitro}

Para a realização desse tipo de experimento fez-se necessária a adaptação de um sistema in vitro baseado no princípio de um "rizotron", ou seja, um tipo específico de câmara de crescimento de plantas o qual se permite a observação, acompanhamento e tomada de medidas das raízes durante todo o período experimental. Dessa forma, as plantas foram incubadas em tubos de ensaio (250mm de comprimento X 2,5mm de diâmetro) (Figura 2A), os quais foram mantidos em inclinação aproximada de $45^{\circ}$ (Figura 2B). Esse ângulo se fez necessário para permitir com que as raízes crescessem junto do lado de baixo do frasco, 
junto a sua parede, possibilitando o acompanhamento do crescimento por meio da marcação semanal do tamanho radicular final na parte externa do tubo (Figura $2 \mathrm{C}$ ).

As plantas utilizadas nesse tipo de experimento corresponderam àquelas com 30 dias de idade, considerando-se o momento inicial a partir da inoculação dos segmentos nodais estiolados em meio de crescimento, segundo descrito no item III.1. Assim, selecionaram-se para esse tipo de experimento as plantas que apresentaram apenas uma raiz, sendo que o tamanho dessa primeira raiz variou de 10 a $15 \mathrm{~mm}$ de comprimento. A primeira raiz formada em cada planta foi acompanhada quanto à taxa de crescimento longitudinal durante todo o período experimental. O meio de cultura utilizado nesse caso foi o mesmo descrito no item III.1, e todas as condições de incubação foram as mesmas utilizadas rotineiramente para obtenção de plantas (ver item III.1).

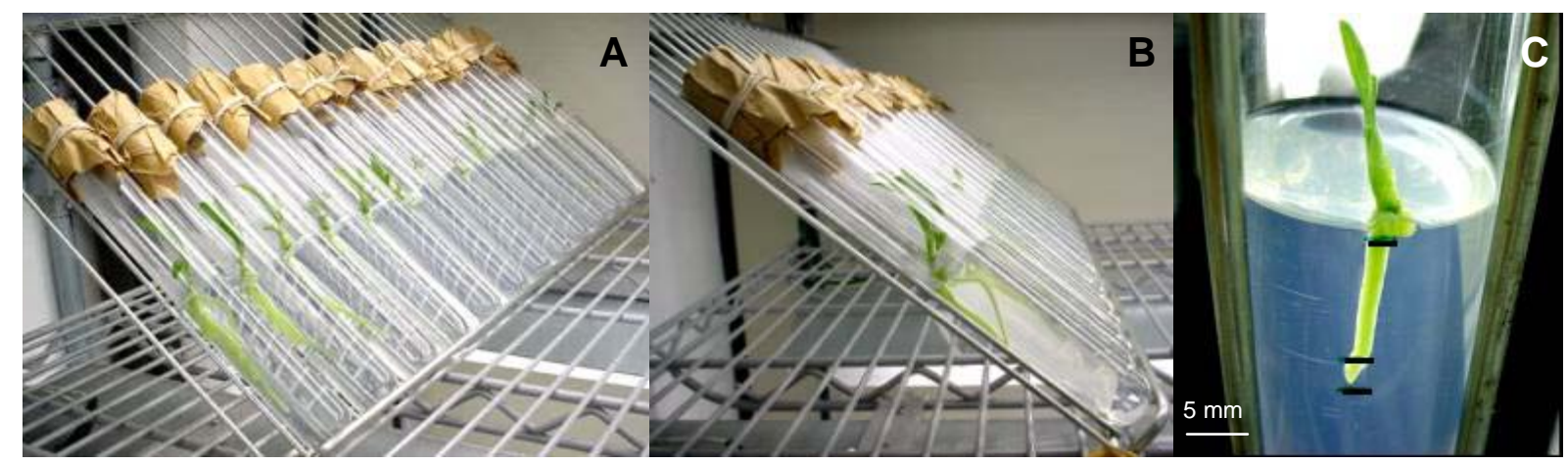

Figura 2: Técnica utilizada para o acompanhamento do crescimento radicular durante 0 desenvolvimento in vitro de plantas de C. fimbriatum. (A) disposição geral dos tubos nas prateleiras da câmara de crescimento de plantas; (B) inclinação em que os tubos foram mantidos; $(C)$ exemplo de marcação semanal do crescimento radicular.

\section{III.2.2. Acompanhamento do desenvolvimento in vitro de ápices radiculares}

Ápices radiculares isolados de plantas com diferentes idades (ver item III.1) foram utilizados como explantes em experimentos em que se teve como objetivo o acompanhamento do desenvolvimento in vitro desse material em diferentes estágios, no 
entanto, de maneira independente da parte-aérea. Para cada objetivo e conjunto experimental utilizou-se explantes isolados de plantas com diferentes idades, estando estas indicadas juntamente ao delineamento do experimento.

Após o isolamento, os explantes foram inoculados no meio de cultura de VACIN e WENT (1949), modificado pela substituição de citrato de ferro por Fe-EDTA, adição dos micronutrientes de MURASHIGE e SKOOG (1962), suplementação de 20g/L de sacarose e geleificação com $2 \mathrm{~g} / \mathrm{L}$ de Phytagel ${ }^{\circledR}$. Essa formulação também foi utilizada como meio básico para os tratamentos em que se efetuou a adição de eventuais substâncias reguladoras de crescimento ao meio de cultura, no entanto, os detalhes de cada uma delas serão especificados juntamente ao delineamento de cada experimento. Todos os experimentos foram mantidos durante o período de análises em câmaras sob temperatura de $26 \pm 1^{\circ} \mathrm{C}$ e luz branca contínua emitida por lâmpadas fluorescentes (tipo luz diurna) de intensidade de $50 \mu$ moles $\cdot \mathrm{m}^{-2} \cdot \mathrm{s}^{-1}$.

\section{III.2.3. Preparo de material para microscopia de varredura}

As amostras foram coletadas e imediatamente fixadas em solução de glutaraldeído 1\% e formaldeído 4\% em tampão fosfato 0,2M, pH 7,2 (KARNOVSKY, 1965) durante 16 horas. Em seguida, foram desidratadas em série etanólica de 5 - 99,5\%, tratadas em solução de hexametildisilazano (HMDS) e etanol 99,5\% (1:1 v/v), e, em seguida, imersas em HMDS puro até a evaporação total desse reagente. Após a secagem, as amostras foram fixadas em porta - amostras ("stubs") e recobertas com 30-35mm de ouro e paládio a $6 \times 10^{-2}$ atm em metalizador (Balzers modelo SCD 050), segundo metodologia descrita por SILVEIRA (1989). As imagens obtidas foram registradas com aparelho fotográfico, utilizando-se filme preto e branco (Verichrome pan ASA 125). 


\section{III.2.4. Método de preparo de material histológico para microscopia de luz}

Todas as amostras foram fixadas em solução de glutaraldeído 1\% e formaldeído 4\% em tampão fosfato 0,2M pH 7,2 (KARNOVSKY, 1965) durante 24 horas, com aplicações de vácuo de 15 minutos de duração a cada hora. Em seguida, as amostras foram desidratadas em série etanólica de 5 - 95\%, pré-infiltradas com solução de Historresina ${ }^{\circledR}$ (Leica) e etanol 95\% (1:1, v/v) durante 24 horas, infiltradas em Historresina ${ }^{\circledR}$ pura (Leica) por cinco dias a $4^{\circ} \mathrm{C}$ e, em seguida, foram incluídas em Historresina ${ }^{\circledR}$ (Leica) adicionada de substância endurecedora e ativadora fornecida pelo fabricante.

Das amostras incluídas foram feitos cortes longitudinais seriados ( $5 \mu \mathrm{m}$ de espessura), utilizando-se um micrótomo rotativo com navalha descartável de vidro. A coloração dos cortes foi obtida com azul de toluidina (C.I. 52040) a 0,05\% em tampão fosfato $0,2 \mathrm{M}$ e pH 6,8 durante 5 minutos. Os aspectos estruturais mais relevantes foram registrados com fotomicroscópio.

\section{III.2.5. Preparo do material histológico para microscopia de fluorescência}

Os cortes foram realizados à mão-livre, procurando atingir a região mediana dos ápices radiculares recém-isolados com idades desejadas para cada conjunto experimental. Após a obtenção dos cortes frescos, lâminas não permanentes foram montadas em água ultra-purificada, as quais foram imediatamente analisadas. As análises foram realizadas em microscópio de fluorescência Leica DMLB, equipado com uma câmera digital Leica DFC 320 e filtros Leica com características que variaram de acordo com cada experimento, sendo, portanto, especificada nos respectivos delineamentos experimentais. 


\section{III.2.6. Preparo do meio de cultura para análises bioquímicas}

Para o preparo de cada amostra foram utilizados $30 \mathrm{~mL}$ de meio de cultura proveniente de frascos onde as plantas com diferentes idades permaneceram em cultivo segundo descrito no item III.1. Em cada amostra foram adicionados $70 \mathrm{~mL}$ de água ultra-purificada, sendo a mistura homogeneizada vigorosamente por dois minutos consecutivos com o auxílio de um aparelho liquidificador. De cada mistura analisou-se o $\mathrm{pH}$ e retirou-se alíquotas de $100 \mu \mathrm{L}$, as quais foram diluídas em $900 \mu \mathrm{L}$ de água ultra-purificada, sendo que dessas amostras finais foram retiradas as alíquotas correspondentes às utilizadas para análises de conteúdo de amônio dos meios de cultura.

\section{III.2.7. Quantificação de amônio endógeno}

A quantificação de amônio em ápices radiculares ou no meio de cultura de crescimento das plantas baseou-se no método descrito por WEATHERBURN (1967).

Para tanto, cerca de 500mg de massa fresca de ápices radiculares foram macerados em nitrogênio líquido até a formação de um pó fino, ao qual foram adicionados $2 \mathrm{~mL}$ de água ultra-purificada. As amostras foram centrifugadas a 13000rpm por 20 minutos, e o sobrenadante de cada uma delas foi transferido para um novo tubo previamente resfriado. De cada extrato, bem como do meio de cultura preparado de acordo com descrição realizada no item III.2.6, foi retirado uma alíquota de $100 \mu \mathrm{L}$, na qual foram adicionados $500 \mu \mathrm{L}$ da solução de $0,5 \%$ de nitroprussídeo de sódio em fenol, e após agitação moderada em vórtex por 1 minuto, adicionou-se $500 \mu \mathrm{L}$ da solução de hidróxido de sódio em hipoclorito de sódio (5g/L). As amostras foram agitadas novamente em vórtex por 1 minuto cada e após 30 minutos de repouso em temperatura ambiente, realizou-se a leitura do teste colorimétrico em espectofotômetro a $625 \mathrm{~nm}$. 


\section{III.2.8. Quantificação de proteínas totais}

Amostras com cerca de $400 \mathrm{mg}$ de massa fresca foram maceradas na presença constante de nitrogênio líquido, seguindo-se da adição de $750 \mu \mathrm{L}$ do tampão de homogeneização (300mM manitol; 1mM EDTA; 30mM HEPES; 4mM cisteína; pH 7,5). Ao fim do processo de maceração foram adicionados mais $750 \mu \mathrm{L}$ do tampão de homogeneização, esperando-se a mistura descongelar. Realizou-se em seguida uma centrifugação a $14000 \mathrm{~g}$ por 20 minutos (Hettich Universal 30 RF - rotor angular 1412), coletando-se uma alíquota de $100 \mu \mathrm{L}$ do sobrenadante para determinação das proteínas solúveis e de membrana, segundo o método descrito em MARKWELL et al. (1978). Para tanto, utilizou-se uma curva de calibração de BSA (do Inglês "Bovine Serum Albumin" - albumina do soro bovino) e reação colorimétrica de proteínas com o reagente Folin-Ciocalteu. As medidas foram realizadas em 660nm de absorbância.

\section{III.2.9. Quantificação da atividade in vivo da nitrato redutase}

Para a análise da atividade da nitrato redutase foi empregado o método in vivo descrito por JAWORSKI (1971), com modificações realizadas por NIEVOLA e MERCIER (2001). Plantas de C. fimbriatum com diferentes idades foram retiradas dos frascos, lavadas em água destilada, e tiveram seus ápices radiculares isolados (segundo descrito no item III.1) e imediatamente utilizados na realização do ensaio enzimático. Cerca de 400mg de massa fresca foram depositados em tubos de ensaio, aos quais se adicionaram $6 \mathrm{~mL}$ de solução de incubação (tampão fosfato $100 \mathrm{mM}, 4 \%$ de n-propanol e $100 \mathrm{mM}$ de $\mathrm{KNO}_{3}$ ). Antes de se iniciar o experimento, a solução de incubação foi submetida à desgaseificação em sonicador e vácuo por 5 minutos. O tecido vegetal, submerso nessa solução, foi infiltrado sob aplicação de 
vácuo por três vezes em intervalos de 1 minuto. Após isto, os frascos foram mantidos na ausência de luz e em banho-maria a $30^{\circ} \mathrm{C}$ por 1 hora.

Para a determinação da quantidade de nitrito formado pela reação, retirou-se uma alíquota de $1 \mathrm{~mL}$ do meio de incubação de cada amostra, onde adicionaram-se $300 \mu \mathrm{L}$ de sulfanilamida $1 \%$ em $\mathrm{HCl} 3 \mathrm{M}$ e de mais $300 \mu \mathrm{L}$ de $\mathrm{N}$-naftil-etileno-diamino a $0,02 \%$, completando-se o volume final para $2,5 \mathrm{~mL}$ com água ultrafiltrada. As leituras foram realizadas em espectrofotômetro a $540 \mathrm{~nm}$. A atividade enzimática foi expressa em nmoles de $\mathrm{NO}_{2}{ }^{-}$ liberados pelo tecido vegetal na solução de incubação por hora, por grama de matéria fresca (nmoles de $\mathrm{NO}_{2}^{-} \cdot \mathrm{h}^{-1} \cdot \mathrm{gMF}^{-1}$ ).

\section{III.2.10. Quantificação de citocininas endógenas por HPLC}

Os teores endógenos de zeatina (Z), zeatina ribosídica (ZR), isopenteniladenina (iP) e isopenteniladenosina (iPR) foram determinados por HPLC (do Inglês "High Performance Liquid Chromatography" - cromatografia líquida de alta resolução) associada ao método ELISA (do inglês "Ennzyme Linked İmmuno Sorbent Assay" - ensaio imunoenzimático).

\section{Extração}

Amostras com cerca de 400mg de massa fresca foram maceradas em nitrogênio líquido e, em seguida, homogeneizadas com $5 \mathrm{~mL}$ de uma mistura de extração contendo metanol $80 \%$ e $146 \mu \mathrm{M}$ butilhidroxitolueno (BHT). A cada amostra foram adicionados $100 \mu \mathrm{L}$ de $\mathrm{Z}$ radioativa (25 $\mathrm{Ci} \mathrm{mmol}{ }^{-1}$ de $\left[{ }^{3} \mathrm{H}\right] \mathrm{Z}$ - Isotope Laboratory ${ }^{\circledR}$ ) procurando-se com isto quantificar as perdas ocorridas durante o processo de purificação. 


\section{Purificação e fracionamento dos hormônios}

Após o período de $60 \mathrm{~h}$ a $4^{\circ} \mathrm{C}$ sob agitação, as amostras foram filtradas através de membranas de nitrocelulose (Millipore ${ }^{\circledR}$ ) de 0,45 e de $0,22 \mu \mathrm{m}$ de porosidade e por uma coluna Sep-Pack C-18 (Waters $^{\circledR}$ ) previamente estabilizados com metanol 80\%, sendo as frações retidas na coluna eluídas com metanol $80 \%$. Após a filtragem, os extratos foram concentradas por evaporação a vácuo (Speed-Vac Heto ${ }^{\circledR}$, CT 100), solubilizados em $200 \mu \mathrm{L}$ de ácido fórmico 0,2\% (pH 3,0), e então, submetidos ao fracionamento por HPLC. A separação hormonal foi realizada utilizando-se uma coluna de fase reversa C-18 (Waters ${ }^{\circledR}$, Prep NovaPack HR/60 A, $6 \mu \mathrm{m}, 7.8 \times 300 \mathrm{~mm}$ ) num fluxo de $3 \mathrm{~mL}$. $\mathrm{min}^{-1}$ com um gradiente de metanol / solução de ácido fórmico 0,2\% ( $\mathrm{pH} 3)$. O gradiente utilizado foi de (\% de metanol): 0-10 minutos, 18\%; 11-65 minutos, 33\%; 65-70 minutos, 40\%. Em todos os casos, a solução de ácido fórmico 0,2\% (pH 3) foi adicionada ao metanol para completar 100\%. A absorbância do eluente foi monitorada a 265nm. As frações correspondentes aos hormônios $Z$, ZR, iP e iPR, coletadas em intervalos de 30 segundos abrangendo o tempo de retenção de cada citocinina, foram concentradas sob vácuo (Speed Vac Heto ${ }^{\circledR}$, CT 100), sendo, em seguida, solubilizadas com $400 \mu \mathrm{L}$ de água adicionada de $\mathrm{NaN}_{3}(2,53 \mathrm{mM})$ para a quantificação em imunoensaio.

\section{Quantificação de citocininas por ELISA}

Os teores endógenos de Z, ZR, iP e iPR foram analisados por imunoensaio (ELISA) indireto conforme descrito por PERES et al. (1997). Para tanto, as frações separadas por HPLC correspondentes a essas citocininas, foram secas em liofilizador e, em seguida solubilizadas com $400 \mu \mathrm{L}$ de água ultrafiltrada. Alíquotas das frações correspondentes aos tempos de retenção dos padrões de Z e ZR foram analisados com anticorpos policlonais de coelho anti-ZR. Por outro lado, as frações correspondente a iP e iPR foram analisadas com anticorpos policlonais de coelho anti-iPR. Para a obtenção dos dados de recuperação do padrão radioativo $\left[{ }^{3} \mathrm{H}\right] \mathrm{Z}$, alíquotas de $50 \mu \mathrm{L}$ foram retiradas de cada fração correspondente ao 
tempo de retenção de $Z$, sendo, em seguida, adicionadas de $2 \mathrm{~mL}$ de líquido de cintilação $\left(\right.$ Packard $^{\circledR}$, Ultima Gold MV) e submetidas à contagem radioativa em cintilômetro (Packard ${ }^{\circledR}$, TRI CARB 2100 TR). Os teores de cada hormônio foram medidos quatro vezes em cada amostra e os resultados foram corrigidos, segundo os dados de recuperação do padrão radioativo $\left[{ }^{3} \mathrm{H}\right] \mathrm{Z}$, massa fresca inicial das amostras e o fator de diluição dos extratos.

\section{III.2.11. Quantificação de citocininas, giberelinas e auxinas endógenas por RP- HPLC/ESI-MS/MS}

Todo o procedimento de extração hormonal e preparo das amostras para quantificação de giberelinas, auxinas e citocininas por RP-HPLC/ESI-MS/MS (do Inglês:

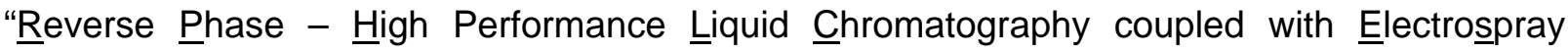
lonization tandem $\underline{\text { Mass }}$ Spectrometry" / cromatografia líquida de alta resolução em fase reversa acoplada à espectrometria de massas em tandem com ionização por electrospray) foi realizado segundo o método descrito por CHIWOCHA et al (2003), em colaboração com o grupo especializado em análises de perfis hormonais no Plant Biotechnology Institute (PBI) do Nacional Research Council of Canada (Saskatoon, SK, Canadá).

\section{Extração}

As amostras coletadas foram liofilizadas durante 24 horas e, em seguida, trituradas até a obtenção de um pó fino. Duplicatas de cada amostra, contendo 30mg de matéria seca cada, foram homogeneizadas em $3 \mathrm{~mL}$ da solução de extração (isopropanol: água: ácido acético glacial na proporção de 80:19:1, v/v). A cada amostra foram adicionados $100 \mu \mathrm{L}$ da mistura de padrões internos deuterados de IAA, IAA-Asp, IAA-Glu, t-ZOG, c-ZOG, $t$-Z, $c$-Z, dhZ, $t$-ZR, c$Z R$, dhZR, 2iP, iPR, $G A_{1}, G A_{3}, G A_{4}$ e $G_{7}$ (solução contendo 0,2ng de cada padrão hormonal/ $\mu \mathrm{L}$ de solução de acetonitrila : água acidificada com $5 \%$ de ácido acético glacial na 
proporção de 1:1, v/v) para possibilitar o cálculo das perdas durante o processo de extração, purificação e separação hormonal. Todas as amostras permaneceram sob agitação durante 24 horas a $4^{\circ} \mathrm{C}$ para a extração hormonal.

\section{Purificação e fracionamento dos hormônios}

Após o período de extração dos hormônios, as amostras foram centrifugadas a 4,4krpm por 10 minutos e o sobrenadante de cada extrato foi transferido para um novo tubo ao qual adicionou-se mais $500 \mu \mathrm{L}$ da solução de extração para uma segunda centrifugação a 4,4 krpm por 10 minutos. Após a centrifugação, o sobrenadante de cada frasco foi adicionado ao primeiro sobrenadante de cada amostra. Todas as amostras foram secas por evaporação a vácuo a $35^{\circ} \mathrm{C}$, com $340 \mathrm{rpm}$ de rotação. Cada amostra seca foi então solubilizada com a seguinte seqüência de solventes: $100 \mu \mathrm{L}$ de metanol acidificado (MeOH:AcOH, 99:1, v/v), $900 \mu \mathrm{L}$ de água bidestilada acidificada $(1 \% \mathrm{AcOH})$ e $2 \mathrm{~mL}$ de hexano. Após a adição do hexano, as amostras foram submetidas à agitação por 45 segundos, sendo mantidas em repouso e no escuro por 30 minutos para permitir a partição de fases da mistura. Após a separação das fases, as amostras foram centrifugadas a 4.4krpm por 10 minutos, seguindose da transferência da fase aquosa para um novo tudo e secagem por evaporação a vácuo a $35^{\circ} \mathrm{C}$, com $340 \mathrm{rpm}$ de rotação.

Em seguida, as amostras foram solubilizadas em $800 \mu \mathrm{L}$ de metanol acidificado (MeOH:AcOH, 99:1, v/v) e 200 $\mu \mathrm{L}$ de água bidestilada acidificada (1\% AcOH), permanecendo por 10 minutos em sonicação. Cada amostra foi transferida para cartuchos de separação do tipo Sep-Pak C18, previamente equilibrados com 3mL de metanol $100 \%$, seguido de $3 \mathrm{~mL}$ de MeOH: $\mathrm{H}_{2} \mathrm{O}: \mathrm{AcOH}(80: 19: 1, \mathrm{v} / \mathrm{v})$. Após a passagem das amostras pelos cartuchos, $500 \mu \mathrm{L}$ da solução de $\mathrm{MeOH}: \mathrm{H}_{2} \mathrm{O}: \mathrm{AcOH}(80: 19: 1$, v/v) foram adicionados aos tubos originais de cada uma delas, sendo esse conteúdo também submetido à passagem nos respectivos cartuchos. 
Após a filtragem e separação, as amostras coletadas foram transferidas para microtubos, onde foram secas por evaporação a vácuo.

As amostras secas foram solubilizadas com a adição de $81 \mu \mathrm{L}$ da solução ( $\mathrm{MeOH}: \mathrm{AcOH}, 99: 1, \mathrm{v} / \mathrm{v})$ com $0,5 \%$ de ácido acético e $0,1 \mathrm{ng} / \mu \mathrm{L}$ dos padrões externos deuterados e mantidas por 5 minutos em banho ultra-sônico, sendo, em seguida, adicionados em cada uma delas $119 \mu \mathrm{L}$ da solução de ácido acético $5 \%$ com $0,1 \mathrm{ng} / \mu \mathrm{L}$ dos padrões externos deuterados. As amostras foram mantidas sob agitação durante 10 minutos, seguidas por mais 10 minutos em banho ultra-sônico e centrifugadas por 10 minutos com $10 \mathrm{krpm}$. De cada amostra foram transferidos $100 \mu \mathrm{L}$ para "vials" apropriados para a injeção automática e separação dos hormônios em HPLC de fase reversa.

Para tanto, utilizou-se um módulo de separação (Waters, Milford, MA, USA) equipado com uma coluna C18 Genesis 4. $\mu \mathrm{M}$ com 100mm X 2.1mm de dimensões Modelo FK10960EJ, Jones Chromatography, Hengoed, UK) com um sistema ternário de solventes compreendendo acetonitrila (A), água deionizada (B) e água acidificada com $5 \%$ de ácido acético glacial (C). As separações foram realizadas em um gradiente crescente de acetonitrila em uma concentração constante de ácido acético glacial de $7 \mathrm{mM}(\mathrm{pH} 3.4)$, com um fluxo inicial de $0,250 \mathrm{~mL} \cdot \mathrm{min}^{-1}$. O gradiente foi aumentado linearmente de $1.0 \%$ de $A, 98,2 \%$ de $B$, 0,8\% de C para $45 \%$ de $A, 54,2 \%$ de $B$ e $0,8 \%$ de $C$ ao longo de 20 minutos e mantido por mais 2 minutos. O conteúdo de acetonitrila foi então aumentado linearmente de 99,2\% de A, 0,0\% de $\mathrm{B}$ e $0,8 \%$ de $\mathrm{C}$ durante 6 minutos. Essas condições foram mantidas durante 2 minutos adicionais com um fluxo de 0,350 mL $\mathrm{min}^{-1}$. Depois de 1 minuto, as condições iniciais foram retornadas e manteve-se essa condição por mais 6 minutos a fim de estabilizar as condições de corrida antes da injeção da próxima amostra. 


\section{Quantificação hormonal}

A quantificação dos hormônios de cada amostra foi realizada por meio de espectometria de massa em tandem (ESI-MS/MS) de acordo com especificações de CHIWOCHA et al (2003). Neste trabalho foram considerados apenas os dados relativos à quantificação de AIA, AIA-Asp, $\mathrm{GA}_{1}, \mathrm{GA}_{7}$, cis-ZR e trans-ZR, uma vez que os demais hormônios foram detectáveis nas amostras, porém não foi possível a sua quantificação.

\section{III.2.12. Quantificação de ácido abscísico por CG-EM-MS}

Para a quantificação do ABA utilizou-se o método de cromatografia gasosa associada à espectrometria de massa, com monitoramento seletivo de íons (GC/MS/ISM, do Inglês:

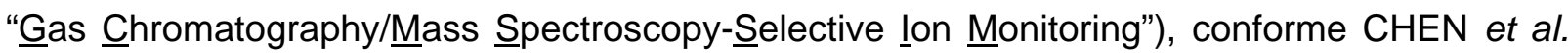
(1988) adaptado por PURGATTO et al. (2002).

\section{Extração}

Cada amostra com cerca de $400 \mathrm{mg}$ foi adicionada de $1 \mu \mathrm{gg}$ do padrão interno de $\left[{ }^{13} \mathrm{C}_{6}\right]$ ABA e $2 \mathrm{~mL}$ da solução de extração (65\% isopropanol em tampão imidazol 0,2M, pH 7,0). As amostras foram homogeneizadas por 1 minuto em homogeneizador Politron ${ }^{\circledR}$, seguindo-se de centrifugação a 15000rpm por 10 minutos. Após a centrifugação, os sobrenadantes de cada amostra foram coletados e o volume total completado para $24 \mathrm{~mL}$ com água ultra-filtrada.

\section{Purificação e fracionamento dos hormônios}

Para a separação da fração que continha o ABA, os extratos foram passados através de cartuchos para extração em fase sólida (Coluna de Amino SPE, 3mL, 500mg, NH2 Agilent Technologies $\left(E \cup A^{\circledR}\right.$ ), sendo que tais cartuchos foram previamente condicionados com lavagens seqüenciais com: $2 \mathrm{~mL}$ de hexano, $2 \mathrm{~mL}$ de acetonitrila, 2 vezes seguidas com $2 \mathrm{~mL}$ 
de água ultra-purificada, $2 \mathrm{~mL}$ de Tampão imidazol $0,2 \mathrm{M} \mathrm{pH} \mathrm{7,0} \mathrm{e,} \mathrm{finalmente,} 4$ vezes seguidas com 2,5mL de água ultra-purificada. As amostras foram aplicadas aos cartuchos pré-condicionados e a passagem dos extratos foi realizada a $4^{\circ} \mathrm{C}$, sem a aplicação de vácuo. Após a passagem de todo o extrato pelo cartucho, realizou-se a lavagem deste com a seqüência de $2 \mathrm{~mL}$ de hexano, $2 \mathrm{~mL}$ de acetato de etila, $2 \mathrm{~mL}$ de acetonitrila e $2 \mathrm{~mL}$ de metanol. Ao fim das lavagens, as frações contendo o ABA foram eluídas dos cartuchos com duas adições de $3 \mathrm{~mL}$ de metanol contendo $2 \%$ de ácido acético ( $/ \mathrm{v})$. As amostras coletadas foram liofilizadas e em seguida solubilizadas com $300 \mu \mathrm{L}$ de metanol $100 \%$. Cada amostra foi metilada com $500 \mu \mathrm{L}$ de diazometano durante 30 minutos em um micro-tubo fechado e em seguida seca em nitrogênio gasoso.

\section{Quantificação hormonal por CG-EM-MS}

As amostras metiladas foram solubilizadas com $50 \mu \mathrm{L}$ de acetato de etila para então serem analisadas em cromatógrafo a gás (CG) Hewlett-Packard modelo 6890 acoplado a um espectômetro de massa modelo 5973. Utilizou-se uma coluna de separação HP-1701 (30m, D.I. $0,25 \mathrm{~mm}$, I.T. $0,5 \mu \mathrm{m})$, tendo hélio como gás de arraste, com fluxo de $1 \mathrm{~mL} \cdot \mathrm{min}^{-1}$. As injeções foram realizadas por meio de injetor automático Hewlett-Packard modelo LS-1100 e o volume injetado de cada amostra foi de $2 \mu \mathrm{L}$, sem a utilização do divisor de amostras (modo "splitless"), com fluxo de ventilação de $20 \mathrm{~mL} / \mathrm{min}$ após 2 minutos da injeção. A coluna foi mantida a $150^{\circ} \mathrm{C}$ por 3 minutos, seguida de rampa de temperatura de $150^{\circ} \mathrm{C}$ até $200^{\circ} \mathrm{C}$ em taxa de $4^{\circ} \mathrm{C} / \mathrm{min}$ e, por fim, de $200^{\circ} \mathrm{C}$ até $300^{\circ} \mathrm{C}$ em taxa de $10^{\circ} \mathrm{C} /$ minuto. Foram monitorados os íons com relação massa/carga (m/z) entre 134, 162 e 190, correspondentes ao ABA endógeno; 138, 166 e 194 correspondentes ao [2H6]-ABA. A concentração endógena de ABA foi calculada pela relação entre as áreas dos picos nos cromatogramas extraídos em m/z 190 e 194. 


\section{III.2.13. Quantificação de etileno por CG-FID}

A produção de etileno foi quantificada com base no método descrito por PURGATTO et al. (2002). Foram retirados $10 \mathrm{~mL}$ do ar interno de cada frasco para a determinação do conteúdo de etileno por GC-FID (do Inglês "Gas Chromatography / Flame Ionization Detector" - cromatografia gasosa com detector de ionização de chama), utilizando-se uma coluna HPPlot (30 m, I.D. 0.53mm) e hélio como gás condutor num fluxo de $1 \mathrm{~mL} / \mathrm{min}$. O injetor e o detector foram mantidos a $250^{\circ} \mathrm{C}$ e a coluna isotermal a $30^{\circ} \mathrm{C}$. Para a curva de calibração foram utilizadas diferentes concentrações de etileno (1-100ppm) obtidas por meio da diluição do gás de calibração (500ppm) com ar sintético

\section{III.2.14. Quantificação de ascorbato e glutationa por HPLC}

A quantificação das formas reduzidas de ascorbato (ASC) e glutationa (GSH) foi realizada por HPLC (cromatografia líquida de alta resolução)

\section{Extração}

Para cada amostra utilizaram-se cerca de 400mg de massa fresca (média de 120 explantes), e as análises foram realizadas em triplicata. As amostras foram maceradas com a adição de nitrogênio líquido até a obtenção de um pó fino. Adicionou-se a cada amostra $1 \mathrm{~mL}$ de ácido metafosfórico 6\% gelado para a extração de ASC e GSH. Depois do descongelamento, a mistura foi centrifugada a $14000 \mathrm{~g}$ por 15 minutos a $4^{\circ} \mathrm{C}$ (Hettich Universal $30 \mathrm{RF}$ - rotor angular 1412) e o sobrenadante foi coletado e diluído na proporção de 1:3 da fase móvel ( $\mathrm{KCl} 2 \mathrm{mM}$, pH 2.5) para a injeção e separação por HPLC. 
Determinação de ASC e GSH por HPLC

A determinação de ASC e GSH foi realizada utilizando-se um sistema de cromatografia líquida de alto desempenho (HPLC) Waters ${ }^{\circledR}$. A separação ocorreu em uma coluna tipo C-18 de fase reversa (Polaris 3 C18 column, Varian Europe), a qual foi mantida em temperatura constante de $28^{\circ} \mathrm{C}$. A fase móvel consistiu de solução de $\mathrm{KCl} 2 \mathrm{mM}$ com $\mathrm{pH}$ acertado para 2,5 com a adição de ácido o-fosfórico concentrado. O fluxo da fase móvel foi mantido a 0,8 mL. min $^{-1}$ e a detecção de ASC e GSH foi realizada por meio de um detector UV $\left(\right.$ Waters $\left.^{\circledR}\right)$ em 252nm e 194nm, respectivamente. O cálculo do conteúdo de ASC e GSH foi feito com base na interpolação das medidas de área de cada pico com a sua respectiva curva de calibração.

\section{III.3. Delineamento das análises experimentais}

\section{III.3.1. Análises das modificações morfológicas durante o ganho de competência para conversão do MAR em gemas}

\section{Crescimento radicular durante o desenvolvimento das plantas}

Esse experimento teve como objetivo a observação da dinâmica do crescimento de raízes intacta ligadas às plantas de $C$. fimbriatum durante o desenvolvimento in vitro, bem como determinar a idade da planta em que as raízes alcançariam o crescimento máximo (crescimento radicular determinado). O delineamento experimental seguiu as especificações indicadas no item III.2.1, sendo a taxa de crescimento radicular semanal obtidas até as plantas alcançarem 240 dias de idade. Foram realizadas duas repetições de todo o experimental, sendo cada uma delas representada por um número amostral de 15 plantas. São apresentados os resultados obtidos em uma das repetições do experimento. 
Comportamento in vitro de ápices radiculares isolados com diferentes idades

Ápices radiculares isolados de plantas de C. fimbriatum com 30, 60, 120 ou 240 dias de idade obtidas segundo o item III.1 foram submetidos a 20 dias de incubação em meio básico de VACIN e WENT (1949), segundo especificado no item III.2.2. Ao fim do período experimental analisou-se a porcentagem média de ápices radiculares convertidos em gemas caulinares e as alterações fenotípicas apresentadas pelos explantes.

Massas fresca, massa seca e conteúdo relativo de áqua de ápices radiculares com diferentes idades

A massa fresca (MF) e massa seca (MS) foram determinadas em ápices radiculares isolados de plantas crescidas por 30, 60, 120 ou 240 dias nas condições descritas no item III.1; para tanto, utilizaram-se de 300 explantes divididos em 3 repetições de 100. Com base nos dados obtidos, calculou-se o conteúdo relativo de água das amostras partindo-se da equação (MF - MS) / MS x 100, segundo descrito por MARTIN e SCHMITT (1989).

Modificações morfológicas externas do MAR ao longo do envelhecimento

Com o objetivo de se analisar com maior profundidade as alterações morfológicas externas na região apical da raiz ao longo do envelhecimento, utilizou-se a técnica de microscopia eletrônica de varredura (MEV), em um equipamento da marca Zeiss modelo DSM 940, cujos recursos possibilitam o acompanhamento de alterações na superfície do objeto de estudo com substancial definição de imagem. Para tanto, utilizaram-se ápices radiculares isolados de plantas com 30, 60, 120 e 240 dias de idade, os quais foram fixados após o isolamento e preparados para a análise em microscopia de varredura, segundo especificado no item III.2.3. Três explantes foram utilizados para cada tratamento. 
Modificações histológicas do ápice radicular ao longo do envelhecimento

Microscopia de Luz

As amostras consistiram de ápices radiculares provenientes de plantas com 30, 60, 120 e 240 dias (obtidas conforme item III.1), os quais foram fixados após o isolamento da planta-mãe. Todo o procedimento de preparo das amostras para as análises histológicas em microscopia de luz está especificado no item III.2.4. As análises foram realizadas utilizando-se três ápices radiculares para cada tratamento.

\section{Microscopia de fluorescência}

Essa técnica foi utilizada objetivando um melhor entendimento sobre as mudanças estruturais dos tecidos radiculares de $C$. fimbriatum ao longo do envelhecimento, e ao mesmo tempo, uma melhor compreensão do padrão de autofluorescência destes em diferentes idades. Para tanto, ápices radiculares recém-isolados $(5 \pm 1 \mathrm{~mm})$ de plantas de $C$. fimbriatum com 30, 60, 120 e 240 dias de idade foram cortados à mão-livre e preparados para a análise histológica em microscopia de fluorescência, segundo descrito no item III.2.5, utilizando-se filtros Leica com as características especificadas na tabela 1. Para cada condição analisada foram utilizados cortes histológicos obtidos de três ápices radiculares.

Tabela 1: Tipos de filtros com seus respectivos comprimentos de onda de excitação $e$ emissão utilizados para as análises em microscopia de fluorescência.

\begin{tabular}{ccc}
\hline Tipo de Filtro & $\begin{array}{c}\text { Comprimento de onda de } \\
\text { excitação (nm) }\end{array}$ & $\begin{array}{c}\text { Comprimento de onda de } \\
\text { emissão (nm) }\end{array}$ \\
\hline Luz visível (sem filtro) & --- & --- \\
\hline H2 (vermelho e verde) & $420-490$ & 515 \\
\hline H3 (azul) & $340-380$ & 425 \\
\hline
\end{tabular}


Efeitos do isolamento sobre as modificações histológicas de ápices radiculares competentes

Neste experimento utilizaram-se explantes isolados de plantas com 120 dias de idade. Definiu-se essa idade com base em experimentos prévios em que se verificou que plantas com essa idade possuiam a maioria das raízes com ápices mais competentes para a conversão em gemas, e folhas sem apresentarem ainda folhas amarelecidas. Deve-se ressaltar que, além da padronização da idade (tempo de desenvolvimento das plantas), consideraram-se para esse tipo de experimento apenas os ápices isolados de duas raízes mais velhas de cada planta.

Dessa forma, ápices radiculares isolados de plantas com 120 dias de idade foram submetidos a diferentes tempos de incubação $(0,12,24,36,48$ ou 240 horas) sob as condições apresentadas no item III.2.2. Os ápices radiculares não submetidos à incubação (tempo zero) foram tomados como controle. Após os tratamentos, as amostras foram coletas e imediatamente fixadas para, em seguida, serem preparadas para análises histológicas em microscopias de luz, segundo o método descrito no item III.2.4. Todas as análises foram realizadas em triplicata.

\section{III.3.2. Análises das modificações bioquímicas durante o ganho de competência}

\section{Quantificação do conteúdo de proteínas totais}

As amostras utilizadas foram ápices radiculares isolados de plantas incubadas por 30, 60, 120 e 240 dias sob condições descritas no item III.1. Após o isolamento dos materiais, estes foram congelados em nitrogênio líquido e mantidos em freezer $-80^{\circ} \mathrm{C}$ até a sua utilização para quantificação do conteúdo de proteínas totais, utilizando-se o método descrito no item III.2.8. As análises foram realizadas em triplicata, com cerca de 120 explantes em cada repetição. 
Modificações histoquímicas - proteínas

Para essa abordagem experimental utilizaram-se como amostras ápices radiculares isolados de plantas com 30 e 240 dias de idade, sendo que após a coleta esses explantes foram imediatamente fixados em solução de glutaraldeído 1\% e formaldeído $4 \%$ em tampão fosfato $0,2 \mathrm{M} \mathrm{pH} \mathrm{7,2} \mathrm{(KARNOVSKY,} \mathrm{1965)} \mathrm{durante} 24$ horas, com aplicações de vácuo de 15 minutos de duração a cada hora. Em seguida, as amostras foram desidratadas em série butírica (álcool butírico terciário), incluídas em "paraplast" e cortadas com a espessura de $5 \mu \mathrm{m}$, em micrótomo rotatório. Os cortes seriados longitudinas da região mediana dos ápices radiculares foram corados de acordo com FISCHER (1968). As análises foram realizadas em triplicata.

Quantificação do conteúdo de amônio

Para a quantificação de amônio utilizaram-se tanto amostras de tecidos radiculares quanto do meio de cultura onde as raízes foram incubadas. Dessa forma, coletaram-se amostras do meio de cultura onde plantas foram mantidas em desenvolvimento por 30,60 , 120 e 240 dias, as quais foram preparadas para a quantificação do conteúdo de amônio de acordo com a descrição realizada no item III.2.6. As amostras de tecidos consistiram, por sua vez, de ápices radiculares isolados de plantas crescidas por 30, 60, 120 e 240 dias nas condições descritas no item III.1, sendo que o material foi coletado e imediatamente congelado em nitrogênio líquido para, em seguida, ser preparado, juntamente às amostras de meio de cultura, para quantificação do conteúdo de amônio endógeno, segundo o método descrito no item III.2.7. Todas as análises foram realizadas em triplicata.

\section{Quantificação da atividade in vivo da nitrato redutase}

Os ápices radiculares utilizados para estas análises foram isolados de plantas incubadas por 30, 60, 120 e 240 dias, conforme as condições descritas no item III.1. O 
método utilizado para a quantificação da atividade in vivo da nitrato redutase encontra-se descrito no item III.2.9. As análises foram realizadas em triplicata, utilizando-se cerca de 120 explantes para cada repetição.

\section{III.3.3. Análises do papel das citocininas no ganho de competência}

\section{Efeitos do envelhecimento sobre os teores endógenos de citocininas}

Para a quantificação das citocininas Z, ZR, iP e iPR empregaram-se ápices radiculares isolados de plantas crescidas durante 30 e 120 dias nas condições descritas no item III.1. Após o isolamento, as amostras foram congeladas em nitrogênio líquido para, em seguida, serem preparadas para quantificação das citocininas endógenas, segundo o método apresentado no item III.2.10. Para tal fim, utilizaram-se amostras com cerca de 120 ápices radiculares cada.

Ápices radiculares isolados de plantas com 30 e 240 dias de idade, obtidos segundo item III.1, foram utilizados para a quantificação das formas cis-ZR e trans-ZR, conforme descrito no item III.2.11. Foram utilizadas duplicatas de amostras com cerca de 120 explantes em cada.

Efeitos do isolamento de ápices radiculares competentes sobre os teores endógenos de citocininas

Utilizaram-se como amostras ápices radiculares isolados de plantas com 120 dias de idade (ver item III.1.), os quais foram submetidos, logo após o isolamento, a tratamentos que consistiram de diferentes tempos de incubação $(0,2,4,6,8,10,12,24,36$ e 48 horas) sob as condições apresentadas no item III.2.2.

Os ápices radiculares não submetidos à incubação (tempo zero) foram tomados como controle. Após os tratamentos, as amostras foram coletas e imediatamente congeladas em 
nitrogênio líquido para, em seguida, serem preparadas para quantificação de citocininas endógenas, segundo o método descrito no item III.2.10. Esse experimento foi realizado com amostras contendo cerca de 120 explantes em cada tratamento.

Efeitos da aplicação de citocinina exógena sobre o tempo de conversão de ápices radiculares competentes

Nessa etapa, utilizaram-se como amostras ápices radiculares isolados de plantas crescidas por 120 dias nas condições descritas no item III.1. Os explantes recém-isolados foram submetidos à aplicação de pulsos com diferentes períodos de duração $(0,12,24,36 \mathrm{e}$ 48 horas) na presença de $0,125 \mathrm{mg} / \mathrm{L}$ da citocinina benziladenina (BA). Após os períodos de tratamento na presença de BA, os explantes foram transferidos para o meio básico de VACIN e WENT (1949) (ver item III.2.2). Todas as demais condições de incubação foram mantidas segundo descrito no item III.2.2. O controle consistiu de explantes que permaneceram em incubação em meio básico sob as mesmas condições de cultura. Após 5 dias de incubação verificou-se as modificações apicais dos explantes, sendo que ao fim de 30 dias confirmou-se o número de conversões de ápices radiculares em gemas caulinares. Também se realizou a incubação permanente de explantes da mesma procedência no meio suplemantado por 0,125mg/L de BA, sendo acompanhado o número de explantes convertidos em gemas caulinares a cada cinco dias até $030^{\circ}$ dia de incubação. Cada tratamento foi realizado em triplicata de dez explantes cada.

\section{Efeitos de diferentes citocininas exógenas sobre a aquisição de competência}

Com o intuído de se verificar um possível efeito de diferentes tipos de citocininas sobre a aquisição de competência de ápices radiculares, realizou-se tratamentos com $1 \mu \mathrm{M}$ de Z, ZR, iP e iPR em ápices radiculares isolados de plantas com 30 dias de idade, obtidos segundo descrição no item III.1. Os explantes foram submetidos a 30 dias de incubação em 
meio básico de VACIN e WENT (1949), segundo especificado no item III.2.2. Ao fim do período experimental analisou-se o tamanho final dos ápices radiculares, a porcentagem de ápices radiculares e as alterações fenotípicas dos explantes.

Efeitos da aplicação de citocininas sobre o desenvolvimento de ápices radiculares ligados a plantas velhas

Nesse experimento procurou-se avaliar o potencial de respostas organogênicas de ápices radiculares ligados a plantas com 240 dias de idade incubadas na presença de uma citocinina exógena. Para tanto, plantas intactas foram retiradas cuidadosamente dos frascos onde se desenvolveram (descrição no item III.1), e imediatamente transferidas para um novo meio de cultura de VACIN e WENT (1949) suplementado com $1 \mu \mathrm{M}$ de zeatina. Como controle empregou-se esse mesmo meio de cultura, porém desprovido de citocinina.

As plantas foram mantidas nesse novo meio de cultura por 30 dias, utilizando-se $50 \mu$ moles. $\mathrm{m}^{-2} \cdot \mathrm{s}^{-1}$ de intensidade luminosa, 16 horas de luz e temperatura de $26 \pm 1^{\circ} \mathrm{C}$. Ao fim do período de incubação verificou-se o aspecto morfológico do sistema radicular, bem como a porcentagem de raízes que apresentaram a retomada do crescimento longitudinal ou a conversão dos ápices radiculares em gemas caulinares. Nesse experimento foram utilizadas três repetições com 5 plantas em cada.

\section{III.3.4. Análises do papel da auxina no ganho de competência}

\section{Efeitos do envelhecimento sobre os teores endógenos de auxinas}

Para a análise das variações dos teores endógenos de auxinas durante o envelhecimento radicular utilizaram-se ápices radiculares isolados de plantas com 30 e 240 dias de idade (descrição no item III.1). Depois de isolados, estes foram imediatamente mergulhados em nitrogênio líquido e mantidos em freezer $-80^{\circ} \mathrm{C}$ até o momento das análises 
dos teores endógenos de AIA e AIA-Asp, segundo método descrito no item III.2.11. Essas análises foram realizadas em duplicatas, sendo que em cada repetição empregou-se cerca de 120 explantes.

\section{Efeitos do NPA sobre a taxa de crescimento radicular}

Nesse experimento foi avaliado o efeito de tratamentos com NPA (ácido N-1naftilftalâmico), uma substância inibidora do transporte polar de auxina, sobre o crescimento radicular de plantas intactas de $C$. fimbriatum. Para isto, plantas com 30 dias de idade (obtidas segundo descrito no item III.1) foram inoculadas em meio de cultura de VACIN e WENT (1949) suplementado com 10; 100 ou $1000 \mu \mathrm{M}$ de NPA. O NPA foi acrescentado ao meio básico através de ultra-filtros de malha $0,22 \mu \mathrm{m}$ Millipore ${ }^{\circledR}$, sendo o $\mathrm{pH}$ das soluções ajustado previamente para 5,8 .

Os valores da taxa de crescimento radicular foram obtidos durante o desenvolvimento in vitro das plantas, sendo o procedimento experimental realizado de acordo com o descrito no item III.2.1. Os tratamentos foram mantidos sob as condições de incubação indicadas no item III.1. O material controle neste caso consistiu de plantas intactas incubadas em meio básico sem a suplementação de NPA. Foram realizadas duas repetições de todo o experimental e em cada uma delas utilizou-se um número amostral de 15 plantas. São apresentados os resultados obtidos em um dos experimentos.

Efeitos do NPA sobre as modificações histológicas no MAR de plantas jovens

Plantas com 30 dias de idade foram transferidas das condições de crescimento descritas no item III.1 para meios adicionados de 10, 100 e 1000 $\mu \mathrm{M}$ de NPA, onde foram incubadas por 10 dias. Terminado esse período (equivalente a plantas com 40 dias de idade), isolaram-se os seus ápices radiculares, os quais foram imediatamente fixados para preparação destinada às análises histológicas, conforme descrito no item III.2.4. 
O material controle consistiu de ápices radiculares isolados diretamente de plantas com 40 dias, o qual não passou por tratamento algum (descrito em III.1). Os tratamentos foram mantidos sob as mesmas condições de incubação utilizadas para o crescimento das plantas (ver item III.1). O NPA foi acrescentado ao meio de cultura por meio de ultrafiltragem, segundo as especificações apontadas no item anterior. As análises histológicas foram realizadas utilizando-se triplicatas de ápices radiculares.

\section{Efeitos do NPA sobre os teores endógenos de citocininas nos ápices radiculares jovens}

Plantas com 30 dias de idade foram transferidas das condições de crescimento descritas no item III.1 para o meio de cultura contendo $1000 \mu \mathrm{M}$ de NPA, onde permaneceram por 10 dias. Terminado esse período (equivalente a plantas com 40 dias de idade), isolaramse os ápices radiculares das plantas, os quais foram imediatamente coletados e congelados em nitrogênio líquido para posterior análise dos teores endógenos de citocininas, segundo o método descrito no item III.2.10.

O material controle consistiu de ápices radiculares isolados diretamente de plantas com 40 dias (ver item III.1). Os tratamentos foram mantidos sob as mesmas condições de incubação utilizadas para o crescimento das plantas (item III.1). O NPA foi acrescentado ao meio de cultura por meio de ultra-filtragem, segundo as mesmas especificações feitas nos itens anteriores, e as análises foram realizadas com amostras compostas por cerca de 120 ápices radiculares cada.

\section{Efeitos do NPA sobre o desenvolvimento in vitro de ápices radiculares jovens}

Teve-se como objetivo estudar uma possível influência do transporte polar de auxina sobre o controle do desenvolvimento do ápice radicular de C. fimbriatum, utilizando-se ápices radiculares isolados de plantas jovens. Dessa forma, empregaram-se como explantes os ápices radiculares isolados de plantas com 30 de idade, obtidas segundo descrito no item 
III.1. Esses explantes foram incubados durante 20 dias no meio básico de VACIN e WENT (1949) suplementado com 0; 10; 30; 100 e 1000 $\mu \mathrm{M}$ de NPA, sendo que os tratamentos foram incubados sob as condições descritas no item III.2.2. O tratamento em que se empregou $1000 \mu \mathrm{M}$ de NPA foi repetido uma segunda vez de maneira independente, no entanto, os explantes foram transferidos após 10 dias sob presença de NPA para um novo meio básico, onde permaneceram em incubação por mais 10 dias.

No final do período de incubação de todos os tratamentos verificaram-se as modificações morfológicas e o tamanho final dos explantes, bem como a porcentagem de ápices radiculares que apresentaram intumescimento na região apical ou conversão do MAR em gemas caulinares. Cada tratamento foi conduzido em quadruplicata com 10 explantes cada.

\section{Efeito da aplicação de AIA sobre o desenvolvimento de ápices radiculares jovens}

Teve-se como objetivo com essa abordagem a verificação da ação do AIA (ácido indolilacético) na atividade do MAR de ápices radiculares isolados de plantas com 30 dias de idade (explantes não-competentes), obtidos segundo descrito no item III.1. Os explantes

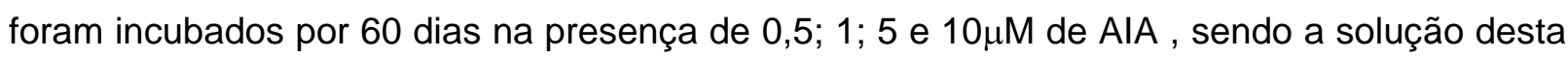
auxina previamente esterelizada através de ultra-filtragem em filtros Millipore ${ }^{\circledR}$ de malha $0,22 \mu \mathrm{m}$, após terem o seu pH ajustado para 5,8. O meio de cultura básico utilizado foi o de VACIN e WENT (1949) (ver item III.2.2), e os experimentos foram mantidos sob as condições de incubação descritas em III.2.2. O controle consistiu de explantes de mesma procedência incubados neste meio de cultura destituído de AIA. Ao fim do período experimental mensurouse o tamanho final dos explantes e registou-se o seu aspecto morfológico. Cada tratamento foi conduzido utilizando-se três repetições com dez explantes em cada. 
Efeitos da aplicação de AIA sobre o desenvolvimento de ápices radiculares ligados a plantas velhas

Essencialmente, procurou-se com essa abordagem investigar a potencialidade organogênica de MARs ligados a plantas já maduras com 240 dias de idade, submetidas à incubação com uma auxina exógena ou a combinação de auxina com uma citocinina. Para tanto, plantas com esta idade foram retiradas do meio de crescimento onde foram incubadas (segundo descrição no item III.1), e imediatamente transferidas para um novo meio de cultura de VACIN e WENT (1949), conforme especificações indicadas no item III.2.2, o qual foi suplementado com $1 \mu \mathrm{M}$ de AIA e com $1 \mu \mathrm{M}$ de AIA juntamente com $1 \mu \mathrm{M}$ de zeatina. O controle seguiu o mesmo delineamento experimental, no entanto, o meio de cultura utilizado foi desprovido de ambos reguladores de crescimento.

As plantas foram incubadas por 30 dias nesses tratamentos, sob $50 \mu$ moles. $\mathrm{m}^{-2} \cdot \mathrm{s}^{-1}$ de intensidade luminosa, 16 horas de luz a uma temperatura de $26 \pm 1^{\circ} \mathrm{C}$. Ao fim deste período, registrou-se o aspecto morfológico do sistema radicular, bem como a porcentagem de raízes que apresentaram a retomada do crescimento longitudinal ou a conversão dos ápices radiculares em gemas caulinares. Nesse experimento foram utilizadas três repetições com 5 plantas em cada.

\section{III.3.5. Análises do papel do etileno no ganho de competência}

\section{$\underline{\text { Teores de etileno ao longo do envelhecimento }}$}

Para a quantificação da emissão de etileno ao longo do desenvolvimento das plantas de C. fimbriatum, utilizaram-se plantas intactas com 30, 60, 120 e 240 dias de idade, obtidas segundo descrito no item III.1. Dessa forma, transferiram-se as plantas para um novo meio de crescimento (descrito no item III.1) com adição de apenas 3g/L de ágar, onde elas permaneceram em aclimatação por 15 dias, sob as mesmas condições de crescimento de 
plantas descritas no item III.1, até o momento das medidas. Decorrido esse período, os frascos foram submetidos a um fluxo de ar sintético contínuo (3L. $\mathrm{min}^{-1}$ ) durante 5 minutos para a eliminação do etileno acumulado, seguindo-se com a vedação dos frascos para o acúmulo de etileno emitido pelas plantas durante um determinado período conhecido. Dentre as condições testadas, verificou-se como mais favorável para a detecção e quantificação de etileno o período de 48 horas de vedação de frascos Erlenmeyers de $125 \mathrm{~mL}$ de capacidade, contendo 30 plantas cada um. A detecção de etileno foi realizada utilizando-se o método descrito no item III.2.13, sendo que as análises foram realizadas em triplicata.

\section{Efeitos do etileno sobre a taxa de crescimento radicular}

Para a detecção do papel do etileno sobre a dinâmica de crescimento radicular ao longo do desenvolvimento de plantas jovens de $C$. fimbriatum, utilizou-se o sistema adaptado in vitro descrito no item III.2.1.

Plantas jovens, com 30 dias de idade, foram submetidas durante 5 semanas

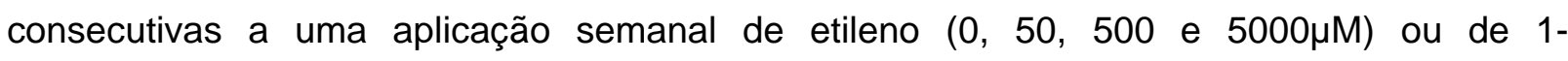
metilciclopropeno SmartFresh ${ }^{\circledR}$ (1-MCP), um bloqueador de receptores de etileno, nas concentrações de $0,0.5,5$ e $50 \mu \mathrm{M}$. A renovação semanal de ambas substâncias foi acompanhada por um fluxo prévio de ar sintético contínuo (3L. $\min ^{-1}$ ) durante 1 minuto. A aplicação de etileno foi realizada sob condições de uma capela, e a aplicação de 1-MCP seguiu-se as orientações do fabricante $\left(\right.$ SmartFresh $\left.^{\circledR}\right)$.

Durante todo o período experimental, as plantas foram mantidas em incubação em sala de crescimento sob condições descritas no item III.1, sendo o crescimento da primeira raiz de cada planta acompanhada e mensurada semanalmente, o mesmo realizado também com relação ao número de conversão do ápice radicular em gema caulinar durante o desenvolvimento das plantas. Foram utilizadas 15 plantas por tratamento como número amostral. 
Efeitos do etileno sobre as modificações histológicas do MAR de plantas jovens

Essa análise teve como objetivo estudar as modificações estruturais do MAR de plantas jovens, submetidas a concentrações elevadas de etileno. Dessa forma, plantas jovens com 30 dias de idade foram submetidas a 10 ou 20 dias de incubação na presença de $500 \mu \mathrm{M}$. Esse tratamento foi renovado semanalmente sob capela logo após a aplicação de um fluxo de ar sintético contínuo (3L. $\mathrm{min}^{-1}$ ) durante 1 minuto. Durante todo o período experimental, as plantas foram incubadas em sala de crescimento sob as condições indicadas no item III.1.

Após o período de tratamento, os ápices radiculares da primeira raiz de cada planta (com idade equivalente a 40 ou 50 dias) foram isolados e imediatamente fixados para as análises histológicas, conforme descrito no item III.2.4. O material controle consistiu de ápices radiculares isolados diretamente de plantas com 45 dias, não submetidas ao tratamento com etileno (obtidas como descrito em III.1). As análises histológicas foram realizadas utilizandose triplicatas de explantes.

\section{Efeitos do etileno sobre o desenvolvimento do sistema radicular de C. fimbriatum}

De maneira complementar, procurou-se observar a ação do etileno sobre desenvolvimento do sistema radicular de C. fimbriatum.

Dessa forma, plantas jovens com 30 dias de idade, foram submetidas durante 5 semanas consecutivas a uma aplicação semanal de etileno $(50,500$ e $5000 \mu \mathrm{M})$ ou de 1-MCP

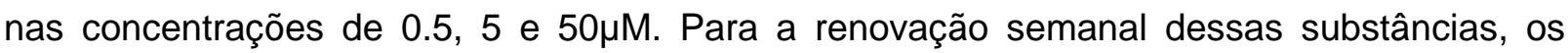
frascos foram submetidos a um fluxo de ar sintético contínuo (3L. $\mathrm{min}^{-1}$ ) durante 1 minuto. A aplicação de etileno foi realizada sob condições de capela, e a aplicação de 1-MCP seguiu as orientações do fabricante $\left(\right.$ SmartFresh $\left.^{\circledR}\right)$.

As plantas foram incubadas durante 120 dias sob as condições descritas no item III.1. No final desse período, foram tomadas medidas de cada planta quanto à massa fresca do sistema radicular, número total de raízes por planta, tamanho final da primeira raiz formada e 
a porcentagem de raízes convertidas em gemas caulinares, sendo os aspectos morfológicos mais proeminentes das plantas também registrados. Utilizou-se um número amostral de 30 plantas por tratamento.

\section{Efeitos do etileno sobre os teores de citocininas}

Plantas com 30 dias de idade, obtidas conforme descrição no item III.1, foram transferidas para frascos contendo $500 \mu \mathrm{M}$ de etileno, conforme indicado no item anterior, onde foram incubadas por 10 dias. Após esse período, foram isolados os ápices radiculares das plantas com idade equivalente a 40 dias, os quais foram imediatamente coletados, mergulhados em nitrogênio líquido e mantidos em freezer $-80^{\circ} \mathrm{C}$ até o momento das análises dos teores endógenos de citocininas. O material controle consistiu de ápices radiculares isolados diretamente de plantas com 40 dias (obtidas como descrito em III.1). Os tratamentos foram mantidos sob as mesmas condições de incubação utilizadas para o crescimento das plantas (item III.1).

Para a quantificação de Z, ZR, iP e iPR utilizaram-se cerca de 120 ápices radiculares para cada amostra, segundo o método descrito no item III.2.10. A quantificação dos isômeros ópticos cis e trans de ZR foi realizada em duplicatas de amostras com cerca de 120 explantes em cada, segundo descrito no item III.2.11.

\section{III.3.6. Análises do conteúdo endógeno de giberelinas e ácido abscísico durante o ganho de competência}

\section{Efeitos do envelhecimento sobre os teores endógenos de giberelinas e ácido abscísico}

Para a análise das variações dos teores endógenos de giberelinas (GA) durante o envelhecimento radicular utilizou-se como amostras ápices radiculares isolados de plantas com 30 e 240 dias de idade, obtidas segundo descrição no item III.1. Para a quantificação de 
ácido abscísico (ABA) utilizou-se ápices radiculares isolados de plantas com 30, 60, 120 e 240 dias de idade. Uma vez isolados, os ápices radiculares foram imediatamente mergulhados em nitrogênio líquido para posterior quantificação dos teores endógenos destes hormônios. A quantificação de $G_{1}$ e $G A_{7}$ foi realizada segundo o método descrito no item III.2.11, utilizando-se duplicata de amostras com cerca de 120 explantes cada. A quantificação de ABA, por sua vez, foi realizada segundo descrição no item III.2.12 utilizandose amostras compostas por cerca de 120 explantes.

\section{III.3.7. Análises do papel do estado redox no ganho de competência}

\section{Efeito do envelhecimento sobre os teores de glutationa e ascorbato}

Nessa etapa teve-se como objetivo verificar as variações nos conteúdos de glutationa (GSH) e ascorbato (ASC) em ápices radiculares durante o envelhecimento. Dessa forma, utilizaram-se ápices radiculares isolados de plantas crescidas por 30, 60, 120 e 240 dias nas condições descritas no item III.1, os quais foram coletados, mergulhados em nitrogênio líquido e armazenadas em freezer $-80^{\circ} \mathrm{C}$ até o momento da quantificação dos teores de ASC e GSH, segundo o método descrito no item III.2.14. As análises foram realizadas em triplicada com cerca de 120 explantes cada.

\section{Efeitos de substâncias indutoras e inibidoras do estresse oxidativo}

Com o objetivo de verificar os efeitos do estresse oxidativo na atividade do MAR de $C$. fimbriatum, ápices radiculares não-competentes para conversão em gemas caulinares, isolados de plantas com 30 dias de idade (ver item III.1), foram submetidos aos tratamentos apresentados na tabela 2.

Todas as substâncias foram acrescentadas ao meio de cultura básico de VACIN e WENT (1949) modificado (ver item III.2.2.), sendo que as soluções de paraquat, menadiona e 
GSH tiveram o pH ajustado para 5,8 e, em seguida, foram adicionadas ao meio de cultura pré-esterelizado em autoclave por meio de ultra-filtragem em filtros de malha $0,22 \mu \mathrm{m}$ Millipore ${ }^{\circledR}$. Os experimentos foram mantidos por 60 dias sob as condições de incubação descritas no item III.2.2. O controle consistiu de ápices radiculares de mesma origem incubados em meio básico sem a suplementação de qualquer uma destas substâncias. O tratamento com $1 \mu \mathrm{M}$ de paraquat foi repetido uma segunda vez, no entanto, com duração de apenas 30 dias, sendo os explantes transferidos em seguida para o meio básico e incubados por mais 30 dias nas mesmas condições já especificadas para o material controle.

Ao fim do período experimental, procederam-se as medições do tamanho dos explantes, a freqüência deles convertidos em gemas caulinares, bem como se registrou o seu aspecto morfológico final. Cada tratamento foi conduzido em três repetições com dez explantes em cada.

Tabela 2: Tratamentos com diferentes substâncias moduladoras do estado redox, utilizandose ápices radiculares isolados de plantas de C. fimbriatum com 30 dias de idade.

\begin{tabular}{lc}
\hline \multicolumn{1}{c}{ Substâncias } & Concentrações \\
\hline Paraquat, um indutor de estresse oxidativo & 0,1 e $1 \mu \mathrm{M}$ \\
\hline Menadiona, um indutor de estresse oxidativo & 1 e $10 \mu \mathrm{M}$ \\
\hline Glutationa (GSH), um inibidor de estresse oxidativo & 0,5 e $1 \mu \mathrm{M}$ \\
\hline
\end{tabular}

Variações de ascorbato e glutationa após o isolamento de ápices radiculares competentes e não competentes

Nessa etapa buscou-se verificar as variações no conteúdo de glutationa (GSH) e ascorbato (ASC) durante os primeiros momentos após o isolamento de ápices radiculares competentes e não-competentes para conversão em gemas caulinares. Dessa forma, as amostras empregadas nas análises foram ápices radiculares isolados de plantas com 30 e 
120 dias de idade, os quais foram submetidos a diferentes períodos de incubação $(0,1,2$ ou 3 dias), conforme condições especificadas no item III.2.2. Após os tratamentos, todo o material foi coletado, imediatamente mergulhado em nitrogênio líquido e armazenado em freezer $-80^{\circ} \mathrm{C}$ até a quantificação do conteúdo de ASC e GSH, segundo o método descrito no item III.2.14. As análises foram realizadas em triplicada com cerca de 120 ápices radiculares cada.

\section{III.3.8. Análises do papel do óxido nítrico no ganho de competência}

\section{Efeitos do óxido nítrico no desenvolvimento in vitro de ápices radiculares jovens}

Para verificar um possível efeito do óxido nítrico (NO) sobre o desenvolvimento de ápices radiculares isolados de plantas jovens, realizaram-se tratamentos com a aplicação de nitroprussiato de sódio (SNP), uma substância liberadora de NO, bem como com carboxiPTIO (cPTIO, uma substância eliminadora de NO). Utilizaram-se como explantes os ápices radiculares isolados de plantas com 30 dias de idade (ver item III.1.), os quais foram

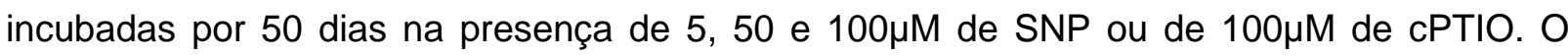
controle consistiu de ápices radiculares incubados permanentemente em meio básico, sendo que todo o experimento foi realizado sob as condições de incubação descritas no item III.2.1. Ao término do período experimental analisou-se o tamanho final e aspecto morfológico dos explantes. Cada tratamento foi conduzido em triplicata com dez explantes cada.

\section{Distribuição do óxido nítrico durante o ganho de competência e na conversão do MAR em} gemas

No intento de se obter evidências de um possível envolvimento do NO endógeno no ganho de competência e conversão do MAR de C. fimbriatum em gemas caulinares, 
realizaram-se análises de localização do NO por fluorescência em cortes frescos de ápices radiculares em diferentes condições.

Primeiramente, verificou-se a possibilidade de participação do NO durante o envelhecimento radicular e na aquisição de competência do MAR para conversão em gemas, analisando-se ápices radiculares isolados de plantas com 30 e 240 dias de idades (obtidas segundo item III.I). De maneira complementar, buscou-se evidências de sua participação no processo de conversão per se, utilizando-se para tanto explantes isolados de plantas com 120 dias de idade (ver item III.I), os quais permaneceram por 30 dias em incubação nas condições descritas no item III.2.1.

Os materiais frescos foram seccionados à mão-livre (ver item III.2.5), e os cortes rapidamente incubados em $20 \mu \mathrm{M}$ de 4,5 diaminofluoresceína diacetato (DAF-2DA) à temperatura ambiente, na ausência de luz e sob agitação constante. Decorridos 30 minutos de incubação, os cortes foram lavados duas vezes com água ultra-filtrada para a retirada do excesso da substância marcadora e, em seguida, montadas lâminas não permanentes, as quais foram imediatamente analisadas sob microscópio de fluorescência Leica DMLB, equipado com uma câmera digital Leica DFC 320 e filtro Leica H3 de comprimentos de onda de excitação de 450-490nm e emissão de 515nm. O material controle consistiu de cortes incubados apenas em água por 30 minutos a temperatura ambiente, sob agitação no escuro. As análises foram realizadas em triplicata de cada material analisado.

\section{III.3.9. Análises do papel do cálcio citossólico no ganho de competência}

\section{Efeitos do cálcio citossólico no desenvolvimento in vitro de ápices radiculares jovens}

Para verificar algum presumível efeito do cálcio citossólico sobre o desenvolvimento de ápices radiculares isolados de plantas jovens, realizaram-se tratamentos com a aplicação 
de ionomicina (um ionóforo de cálcio), bem como com EGTA (uma substância quelante de cálcio citossólico).

Utilizaram-se os ápices radiculares isolados de plantas com 30 dias de idade (ver item III.1.), os quais foram incubados por 30 dias na presença de 10, 100 e $1000 \mathrm{nM}$ de ionomicina ou de $0.1 ; 1$ e 10mM de EGTA. Como controle para o tratamento com ionomicina, um lote de ápices foi incubado permanentemente em meio básico (ver item III.2.1). O controle dos tratamentos com EGTA, por sua vez, foi realizado da mesma maneira, no entanto, eliminouse o $\mathrm{Ca}_{3}\left(\mathrm{PO}_{4}\right)_{2}$ do meio de cultura básico. Todas as substâncias foram acrescentadas ao meio de cultura básico previamente esterelizado em autoclave por meio de ultra-filtragem em filtros $0,22 \mu \mathrm{M}$ Millipore ${ }^{\circledR}$, após o $\mathrm{pH}$ ter sido ajustado para 5,8 . Todos os tratamentos foram mantidos em incubação sob as condições descritas no item III.2.1. Ao término do período experimental tomou-se o tamanho final e o aspecto morfológico dos explantes. Cada tratamento foi conduzido em triplicata de dez explantes cada.

\section{Localização do cálcio citossólico durante a aquisição de competência}

Objetivando obter evidências da possível participação do cálcio citossólico na aquisição de competência para a conversão do MAR de C. fimbriatum em gemas caulinares, realizaram-se análises de localização por fluorescência desse íon em cortes frescos de ápices radiculares isolados de plantas com 30 e 240 dias de idade.

Para isso, foram obtidos cortes longitudinais da região mediana de ápices radiculares recém-isolados ( $5 \pm 1 \mathrm{~mm}$ ), os quais foram submetidos à incubação em solução de fluo-3 AM, uma substância marcadora por fluorescência de cálcio citossólico. Dentre as condições testadas durante a padronização para as análises deste material, a que melhor se adequou a esse tecido foi a incubação dos cortes por 1 hora em solução de fluo-3 AM 10 $\mu \mathrm{M}$ em tampão Tris 10mM ( $\mathrm{pH} 7.0)$, sob escuro, agitação constante e temperatura ambiente. 
Após a incubação, os cortes foram lavados duas vezes consecutivas com tampão Tris 10mM (pH 7.0) para a retirada do excesso da substância marcadora e, em seguida, montados em lâminas não-permanentes utilizando-se esse mesmo tampão. O controle consistiu de lâminas montadas de acordo com o acima mencionado, no entanto, os cortes foram incubados por 1 hora somente em tampão Tris $10 \mathrm{mM}(\mathrm{pH} 7.0)$. As lâminas obtidas foram imediatamente analisadas em microscópio confocal Zeiss LSM 510 Meta nas faixas de excitação de 488nm e emissão 505-530nm. As imagens foram capturadas por meio da passagem do "scanner" sobre os planos de visualização dos cortes por 4 vezes na velocidade 5 do equipamento; todas elas foram trabalhadas utilizando-se o programa Zeiss LSM Image Bowser. As análises foram realizadas em cortes obtidos a partir de triplicata de ápices radiculares.

\section{Análise histológica da formação de idioblastos para estocagem de cálcio no MAR jovem}

As amostras consistiram de ápices radiculares isolados de plantas com 30 dias de idade (obtidas segundo item III.1), os quais foram imediatamente fixados após o isolamento da planta-mãe. O procedimento de preparo das amostras para as análises histológicas em microscopia de luz está especificado no item III.2.4. As análises foram realizadas utilizando-se triplicata de ápices radiculares.

\section{III.4. Análise estatística dos dados}

Os resultados obtidos foram avaliados estatisticamente por meio da análise de variância (ANOVA) e as médias foram comparadas pelo teste de Tukey ao nível de 5\% de significância. 


\section{RESULTADOS}

\section{IV.1. Modificações no ápice radicular durante a aquisição de competência}

Crescimento radicular durante o desenvolvimento in vitro de plantas intactas de C. fimbriatum

Ao se analisar a taxa de crescimento semanal da primeira raiz formada em cada planta de C. fimbriatum verificou-se que o pico de crescimento girou em torno do $50^{\circ}$ dia de idade das plantas. Após esse período, ocorreu uma desaceleração lenta até a parada completa do crescimento radicular por volta $86^{\circ}$ dia de idade das plantas. A partir desse momento, pôde-se verificar que as raízes tinham alcançado o crescimento máximo (crescimento determinado), uma vez que nenhum incremento de tamanho das raízes foi constatado a partir desse momento (Figura 3).

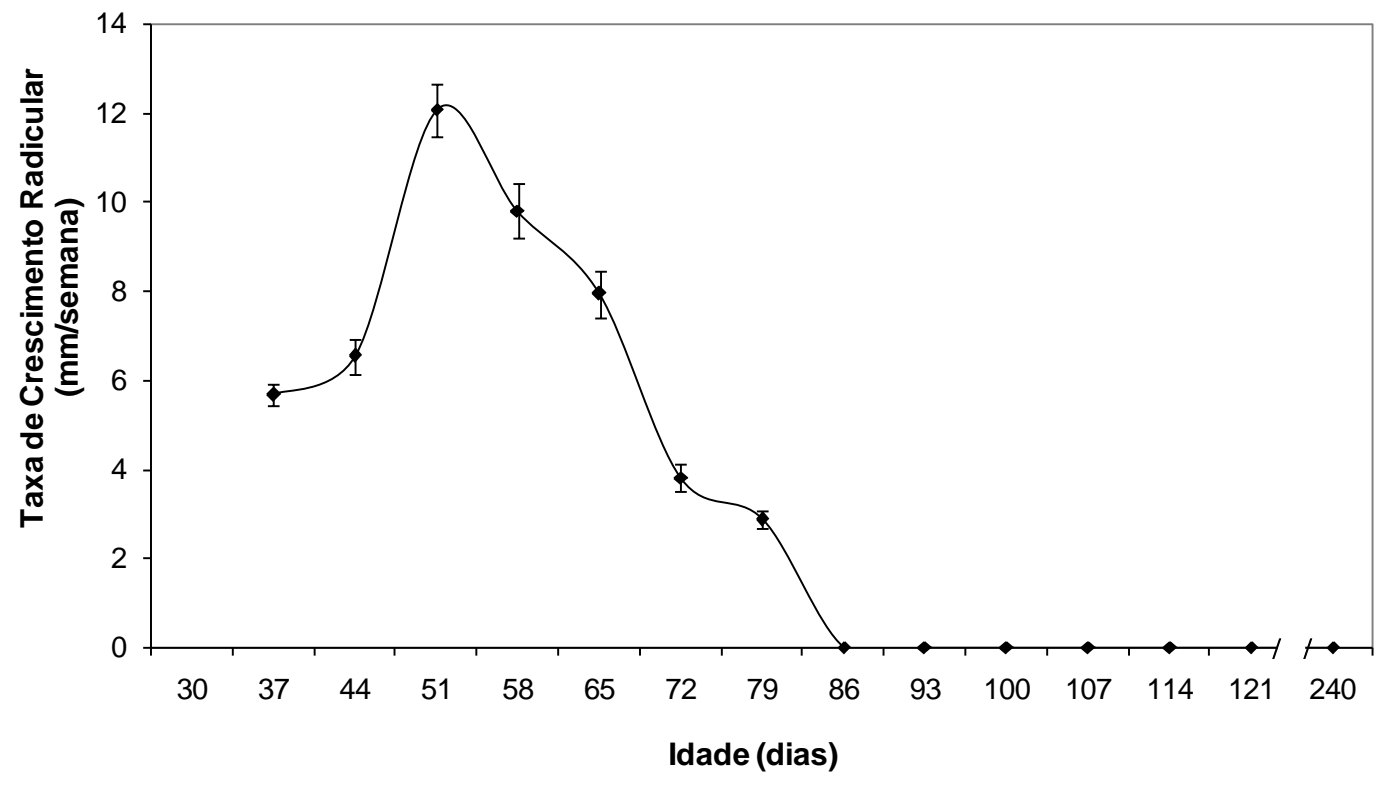

Figura 3: Taxa de crescimento semanal ( $\mathrm{mm} /$ semana) da primeira raiz de plantas de $C$. fimbriatum após 30 dias de idade. As barras de erro indicam o erro padrão. 
Alterações no fenótipo e na competência organogênica de ápices radiculares durante o envelhecimento

A aquisição de competência para conversão do meristema apical radicular (MAR) de C. fimbriatum em gemas caulinares esteve intimamente ligada à parada de crescimento e ao envelhecimento radicular, bem como à ocorrência de profundas modificações morfológicas nos ápices das raízes mais velhas, as quais puderam ser constatadas mesmo a olho nu.

De modo diferente, os ápices de raízes jovens, em processo de intenso crescimento, apresentaram aspecto mais vigoroso e menos clorofilado, como observado nos explantes isolados de plantas com 30 dias de idade (Figura 4A). Esses explantes radiculares jovens, quando isolados da planta-mãe, não apresentaram competência para converterem-se em gemas caulinares e mantiveram o crescimento radicular longitudinal por tempo prolongado após o isolamento (Figura 4B).

Em contrapartida, os ápices de raízes mais velhas possuíram aspecto menos vigoroso e mais clorofilado que o observado nas raízes jovens em crescimento, como pode ser exemplificado com os explantes isolados de plantas com 120 dias de idade (Figura 4C). De maneira complementar, quando os ápices radiculares mais velhos foram isolados e incubados em meio de cultura básico por 20 dias, observou-se a uma rápida conversão em gemas caulinares (Figura 4D). Sob tais circunstâncias praticamente nenhum crescimento longitudinal dos explantes foi constatado (Figura 4D).

Conforme apresentado na figura 4E, cerca de 6\%,70\% e 81\% dos ápices radiculares isolados de plantas com, respectivamente, 60, 120 e 240 dias de idade converteram-se em gemas caulinares após 20 dias de isolamento e incubação em meio de cultura básico. Vale ressaltar que $100 \%$ dos ápices radiculares isolados de plantas com 30 dias de idade não se converteram em gemas caulinares. 


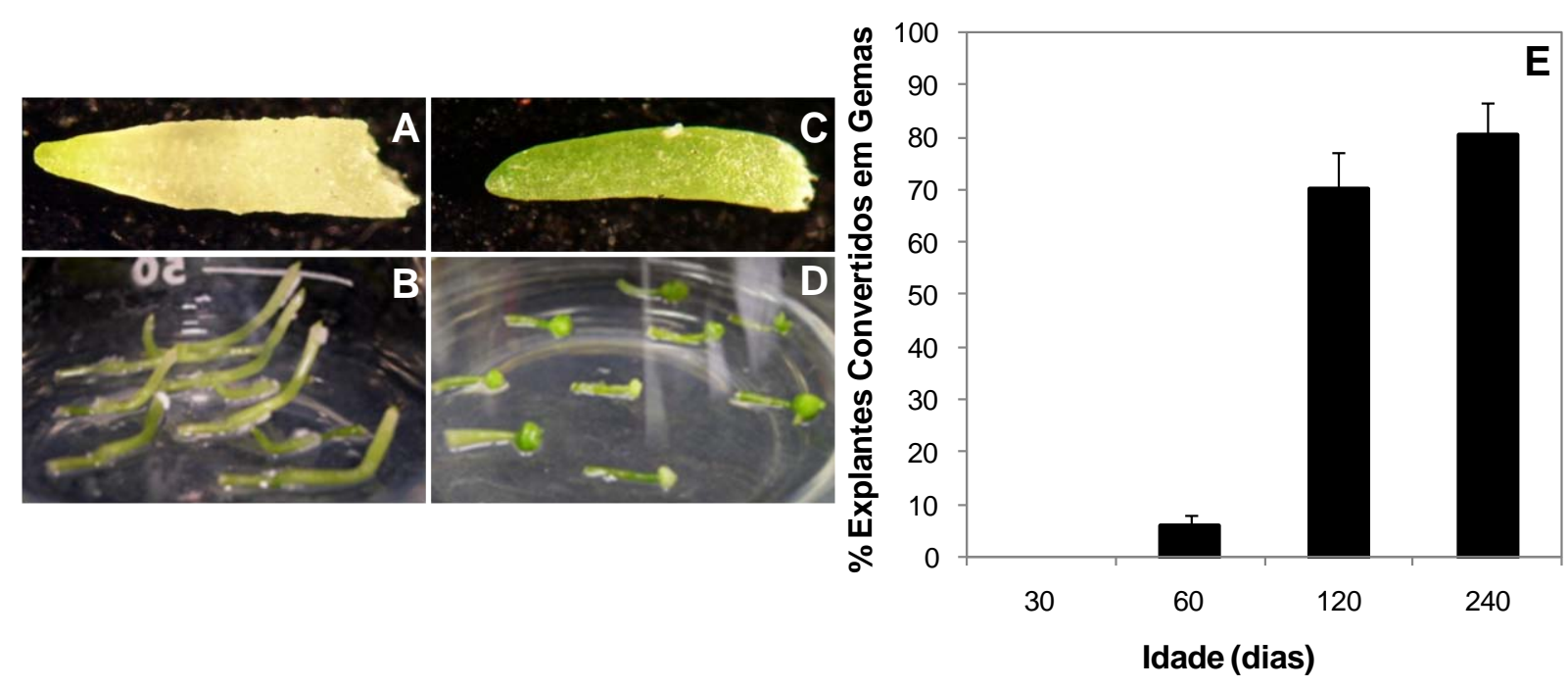

Figura 4: Fenótipo e respostas organogênicas de ápices radiculares isolados de plantas de $C$. fimbriatum com diferentes idades: (A) ápice radicular de plantas com 30 dias de idade; (B) ápices radiculares isolados de plantas com 30 dias de idade e incubados durante 20 dias em meio basal; $(C)$ ápice radicular de planta com 120 dias de idade; $(D)$ ápices radiculares isolados de plantas com 120 dias de idade e incubados durante 20 dias e (E) porcentagem de ápices radiculares isolados de plantas com 30, 60, 120 e 240 dias de idade que apresentaram conversão do MAR em gemas caulinares após 20 dias de incubação. Barras indicam erro padrão.

Dentre as várias alterações morfológicas ocorridas nos ápices radiculares durante o envelhecimento, foi notável a redução da coifa até o seu total desaparecimento (Figura 5).

A análise da superfície dos ápices radiculares revelou que a coifa manteve-se presente recobrindo toda a extensão da região apical das raízes de plantas com 30 e 60 dias de idades (Figuras 5A e 5B, respectivamente). No entanto, verificou-se um certo grau de descamação do tecido da coifa nos ápices radiculares de plantas com 60 dias de idade, quando comparados com a mesma região de plantas mais jovens (Figuras 5B e 5A, respectivamente).

A regressão estrutural da coifa até o seu desaparecimento mostrou-se progressivamente mais expressivo nas raízes que já tinham parado o crescimento, coincidindo com a maior competência para conversão observada nos ápices radiculares isolados de plantas com 120 e 240 dias de idade (Figuras 5C e 5D, respectivamente). 


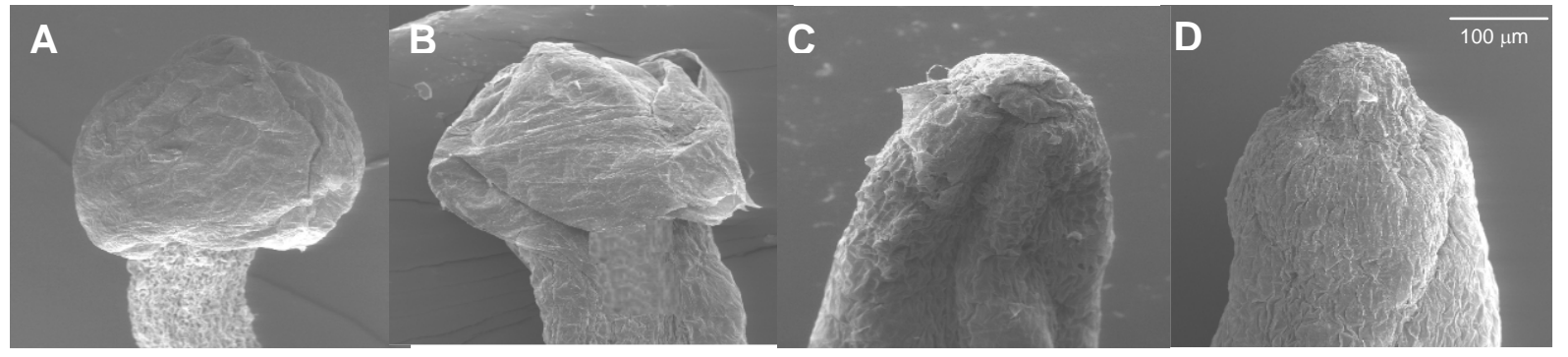

Figura 5: Aspecto sob microscopia eletrônica de varredura da superfície de ápices radiculares recém-isolados de plantas de C. fimbriatum com diferentes idades: $(A)$ Detalhe da coifa de ápice radicular isolado de planta com 30 dias de idade; (B) coifa de ápice radicular isolado de planta com 60 dias de idade; (C) coifa reduzida em ápice radicular isolado de planta com 120 dias de idade $e(D)$ ausência de coifa recobrindo a região apical de raiz de planta com 240 dias de idade.

Modificações morfológicas e bioquímicas em ápices radiculares durante o envelhecimento e aquisição de competência para conversão do MAR em gemas caulinares

As mudanças na morfologia externa dos explantes ao longo do envelhecimento radicular mostraram-se relacionadas com as alterações de massa fresca (MF) e seca (MS), no conteúdo relativo de água, nos teores de alguns compostos nitrogenados, bem como na atividade da nitrato redutase (Figura 6).

Os ápices radiculares de plantas com 120 e 240 dias de idade apresentaram uma redução pronunciada tanto nos valores de massa fresca quanto de massa seca (Figuras 6A e 6B, respectivamente). No entanto, o conteúdo relativo de água sofreu redução significativa apenas nos explantes isolados de plantas com 240 dias de idade (Figura 6C).

O ganho de competência do MAR para conversão em gemas caulinares mostrou-se também relacionado com a diminuição dos teores de importantes participantes do metabolismo do nitrogênio, tais como: proteínas (Figura 6D), amônio (Figura 6E) e atividade da nitrato redutase (Figura 6F). 

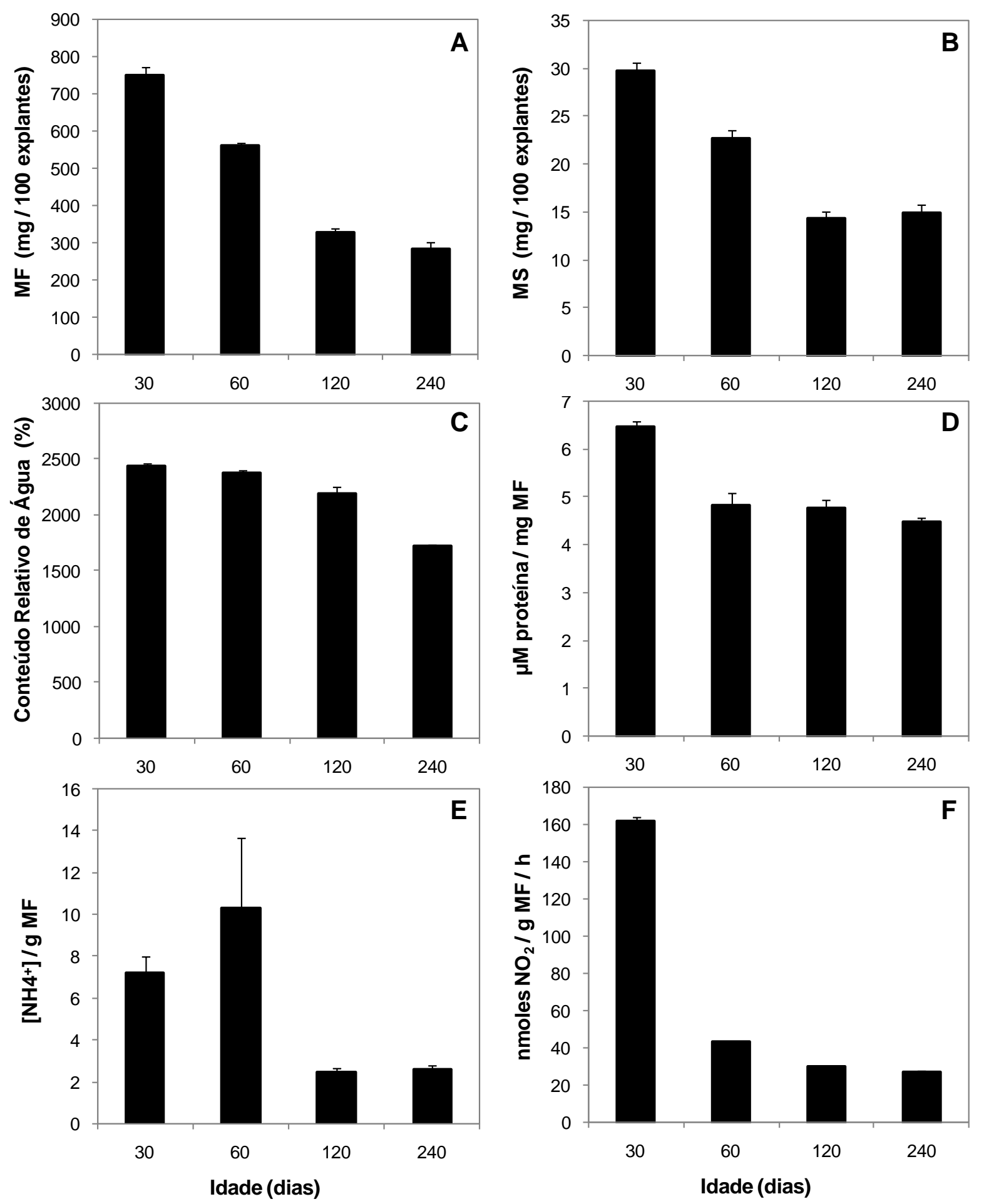

Figura 6: Características morfológicas e bioquímicas de ápices radiculares recém-isolados de plantas de C. fimbriatum com 30, 60, 120 e 240 dias de idade: (A) massa fresca (MF); (B) massa seca (MS); (C) conteúdo relativo de água, $(D)$ conteúdo de proteínas, $(E)$ conteúdo de amônio e (F) atividade da nitrato redutase. As barras de erro indicam erro padrão. 


\section{Alterações no meio de cultura durante o envelhecimento radicular}

As alterações observadas durante o envelhecimento radicular determinantes para a aquisição de competência para conversão do MAR em gemas caulinares também apresentaram relação com as modificações em componentes do meio de cultura onde as plantas foram cultivadas, tais como a concentração de amônio e o pH (Figura 7).

Tomando-se como parâmetro de referência a concetração de amônio e o pH do meio inicial, verificou-se que no $120^{\circ}$ e $240^{\circ}$ dia de incubação da plantas, estes parâmetros apresentaram uma queda conspícua (Figura 7). Ao contrário dos teores de amônio que iniciaram seu declínio a partir do $60^{\circ}$ dia de cultivo (Figura $7 \mathrm{~A}$ ), o valor de pH do meio já apresentou diminuição significativa após apenas 30 dias de incubação das plantas, decrescendo ainda mais até o $120^{\circ}$ e $240^{\circ}$ dia de cultura (Figura 7B).
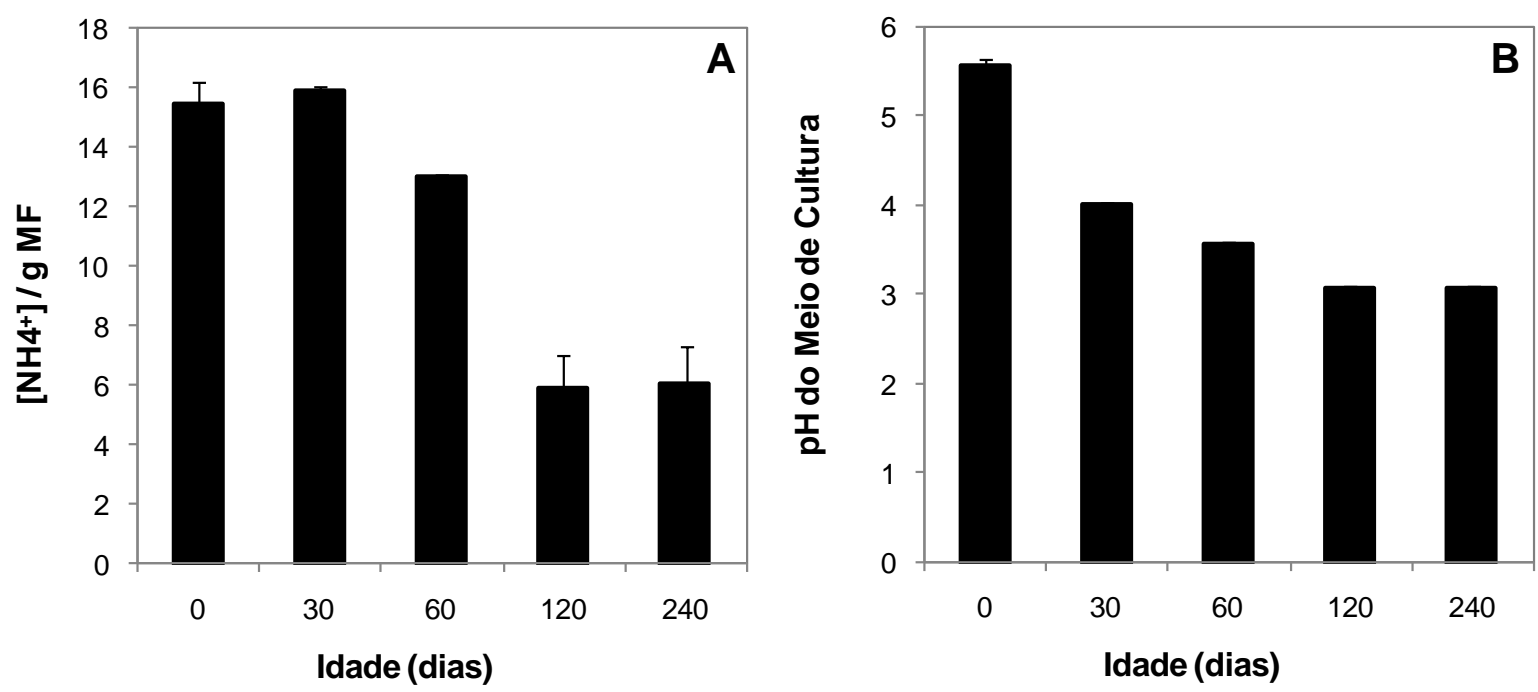

Figura 7: Variações no meio de cultura Vacin \& Went (1949) utilizado durante o desenvolvimento de plantas de C. fimbriatum (descrito no item III.1). O tempo zero refere-se ao meio de cultura antes da inoculação dos explantes e os demais pontos de análises indicam as variações encontradas nos meios de cultura ao longo da incubação das plantas por $30,60,120$ ou 240 dias: (A) conteúdo de amônio e (B) pH do meio. As barras de erro indicam erro padrão. 
Modificações histológicas nos ápices radiculares durante o envelhecimento e a aquisição de competência para conversão do MAR em gemas caulinares

As análises conduzidas sob microscopia de fluorescência com ápices radiculares de plantas de $C$. fimbriatum com diferentes idades revelaram que o ganho de competência para a conversão do MAR em gemas caulinares foi acompanhado de uma intensa diferenciação dos tecidos (Figura 8). Essas análises realizadas com material fresco reforçaram o evento de perda gradativa da coifa durante o envelhecimento radicular, bem como revelaram que explantes isolados de raízes com idade mais avançada tendem a apresentar a região apical com formato achatado ou ainda intumescido (Figura 8A, 8D, 8G e 8J).

Os explantes analisados sob a faixa de comprimento de onda de excitação de 420 a 490nm e emissão de 515nm apresentaram uma tendência ao aumento da fluorescência vermelha nos tecidos ao longo do envelhecimento, indicando um incremento na presença de clorofila nos tecidos. Nessa mesma faixa de comprimento de onda pode-se também observar o aumento da fluorescência verde na região periférica dos explantes, indicando um aumento no número de células da epiderme ou, como no caso dos explantes com idade mais avançada (isolados de plantas com 120 e 240 dias de idade), do velame (epiderme pluriestratificada e morta). É interessante verificar que a fluorescência verde da epiderme nos ápices radiculares de 30 dias de idade é quase inexistente; no entanto, ela aumenta gradativamente em intensidade ao longo do envelhecimento do tecido, inclusive, atingindo regiões cada vez mais próximas à região apical (Figuras $8 \mathrm{~B}, 8 \mathrm{E}, 8 \mathrm{H}$ e $8 \mathrm{~K}$ ). Quando os mesmos explantes foram analisados sob a faixa de comprimento de onda de excitação de 340 a 380nm e emissão de 425nm, verificou-se, por meio da fluorescência em azul, o aumento de importância dos tecidos vasculares (Figuras $8 \mathrm{C}$ e 8F), atingindo a região bem próxima ao MAR nos ápices isolados de plantas com 120 dias de idade (Figura 8I), sendo que naqueles com 240 dias, as células vasculares estiveram presentes no interior da região central do MAR, a qual foi inicialmente ocupada por células meristemáticas (Figura 8L). 
Luz visível
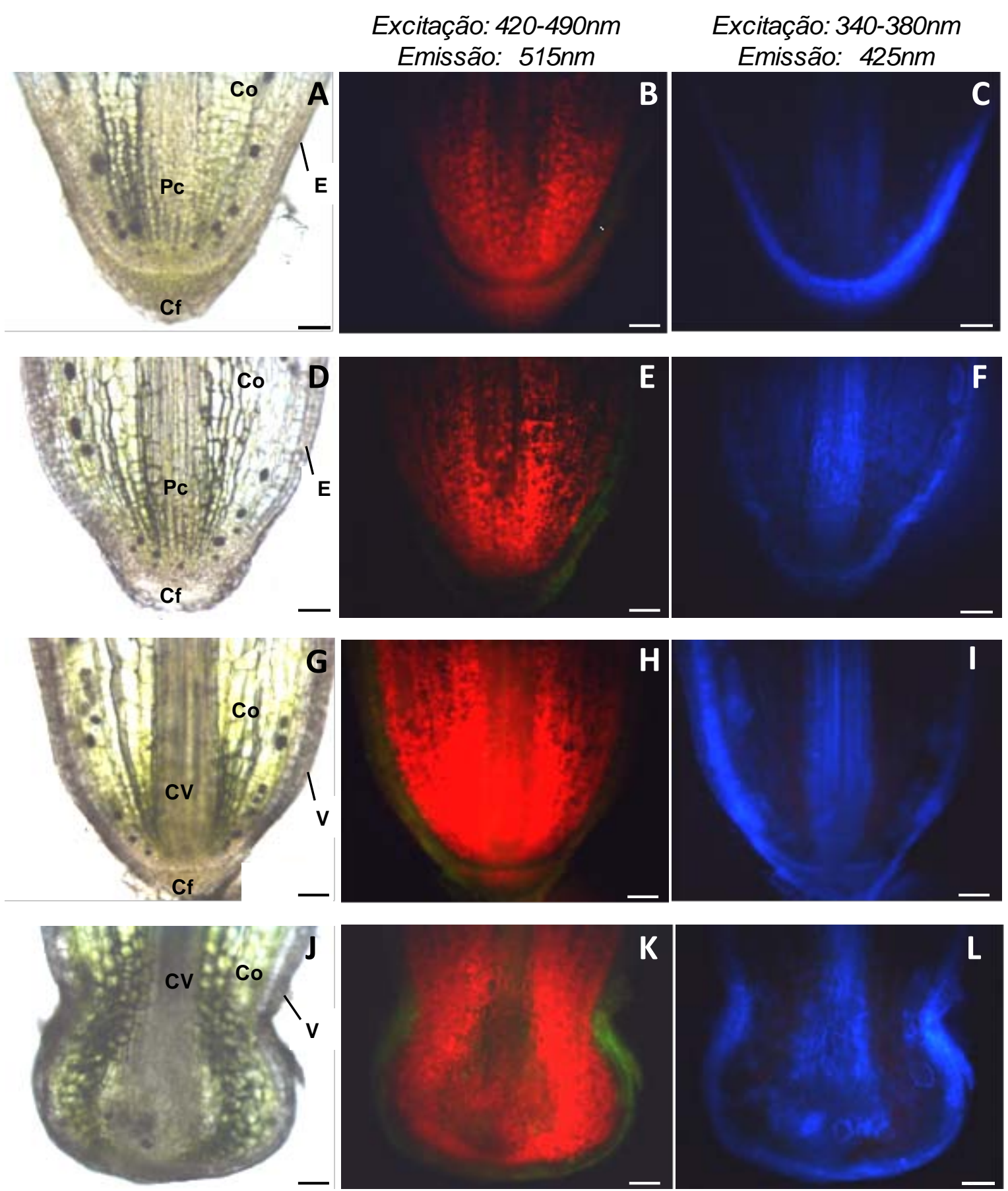

Autofluorescência

Excitação: 420-490nm
Autofluorescência

Excitação: 340-380nm

C

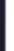

(1)
$\mathbf{F}$
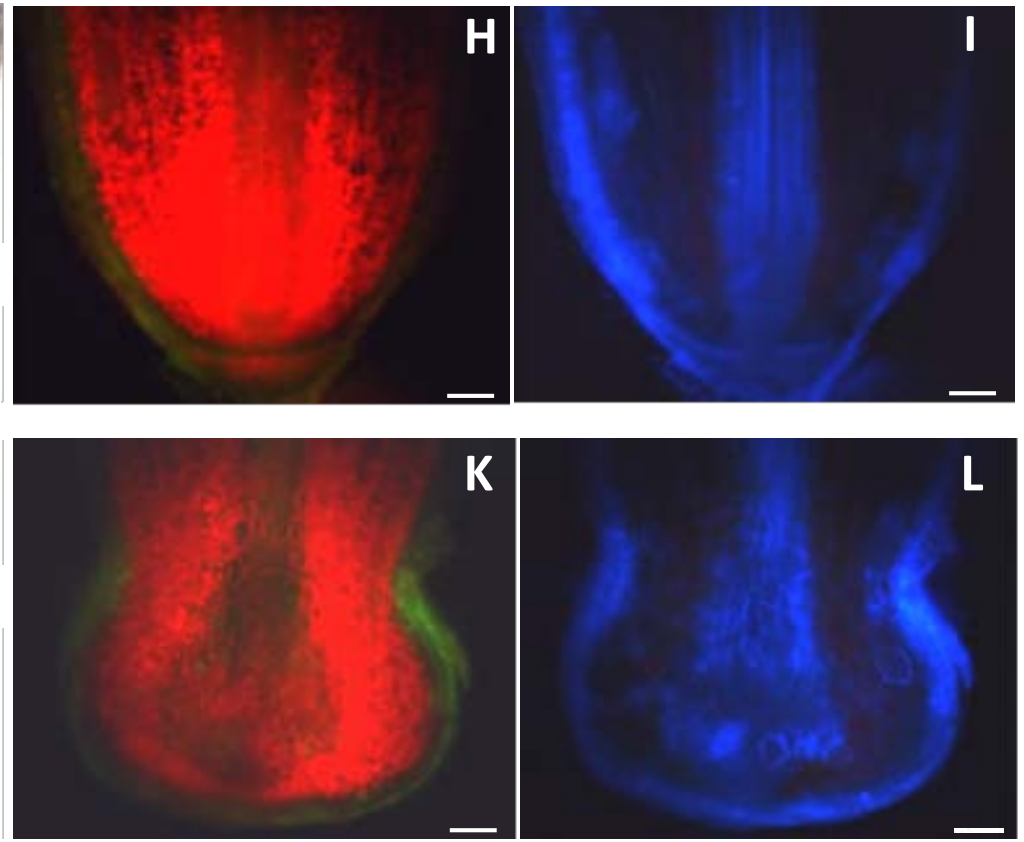

Figura 8: Cortes longitudinais obtidos à mão-livre da região mediana de ápices radiculares recémisolados de plantas de $C$. fimbriatum com diferentes idades: $(A-C) 30$ dias de idade; $(D-F) 60$ dias de idade; (G-I) 120 dias de idade; (J-L) 240 dias de idade. Material fresco analisado sob microscopia de fluorescência, sendo que: $(A, D, G$ e J: luz visível), (B, E, H e K: excitação de 420-490nm e emissão de 515nm) e (C, F, I e L: excitação de 340-380nm e emissão de 425nm). Co (córtex), Pc (procâmbio), E (epiderme), Cf (coifa), CV (cilindro vascular), V (velame). Escala: $100 \mu M$. 
Análises mais detalhadas realizadas com material fixado revelaram que ápices radiculares jovens (isolados de plantas com 30 dias de idade) e ainda não-competentes para conversão em gemas, apresentaram uma organização celular típica de raízes em crescimento, mormente representada por uma região meristemática bem definida no ápice, seguida de uma transição, a qual se presumiu englobar a região de alongamento, e, por fim, uma região com células em início de diferenciação (Figura 9A).

O MAR dessas raízes possuiu uma organização tipicamente fechada, uma vez que foi possível discernir, de maneira nítida, a presença da protoderme localizada entre a coifa e o MAR propriamente dito (Figuras 9A e 10A). No MAR dos explantes jovens a protoderme foi nitidamente formada por uma camada única de células, separando o meristema fundamental e a coifa em toda extensão. Externamente à protoderme, encontrou-se uma coifa formada por diversas camadas celulares, enquanto que na parte interna à protoderme, observou-se a região do meristema fundamental com as células iniciais funcionais organizadas em várias fileiras concêntricas, responsáveis pela origem do córtex, cilindro vascular e demais tecidos maduros da raiz (Figuras 9A e 10A).

As divisões celulares verificadas nos ápices radiculares isolados de plantas com 30 dias de idade estiveram presentes em diferentes tecidos meristemáticos, tais como nas iniciais funcionais do procâmbio, da protoderme e do meristema fundamental (Figuras 11A e 11B). As figuras mitóticas observadas no meristema fundamental freqüentemente localizavam-se na região bem próxima a idioblastos (células com ráfides de oxalato de cálcio) em processo avançado de diferenciação (Figura 11C). As células pertencentes ao meristema fundamental apresentaram características tipicamente de células meristemáticas, ou seja, formato aproximadamente isodiamétrico, núcleos grandes e citoplasmas densos (Figura 10A e 12A). Na porção entre a coifa e o meristema fundamental, observou-se uma região formada por um grupo pequeno de células, também caracteristicamente meristemáticas, para onde 
todas as fileiras de células formadas convergiam, o qual pareceu corresponder ao centro quiescente (CQ) com suas iniciais meristemáticas estruturais (Figura 12A).

Ápices radiculares isolados de plantas com 60 dias de idade evidenciaram fortes indícios de desaceleração no crescimento radicular, tendo em vista a aproximação da zona que englobava as células diferenciadas em relação à região apical dos explantes (Figura 9B). As células do córtex apresentaram-se numa proximidade tal com o meristema fundamental, que a zona de alongamento celular pareceu ter sido reduzida a poucas células, em uma posição de transição entre as células ainda meristemáticas e aquelas já claramente diferenciadas. A coifa apresentou-se ligeiramente reduzida em tamanho (Figura 9B). Ápices radiculares isolados de plantas com 60 dias de idade e analisados sob maior aumento permitiram a confirmação de que a região do meristema fundamental foi reduzida em grande proporção; no entanto, foi possível verificar a organização das células ainda obedecendo ao padrão de MAR fechado (Figura 10B). As células iniciais funcionais apresentaram-se em número acentuadamente reduzido, ao redor do presumível CQ (Figura 10B).

As análises histológicas de ápices radiculares isolados de plantas com 120 dias de idade, os quais corresponderam aos explantes já competentes para conversão após o isolamento, mostraram um avanço ainda maior na diferenciação dos tecidos radiculares em direção ao ápice, sendo que a região de alongamento celular pareceu ter desaparecido, ou diminuído drasticamente a ponto de não ser mais possível distingui-la como tal. O MAR e a coifa ainda se apresentavam com número reduzido de células (Figura 9C). Conforme é dado verificar ainda, após 4 meses de desenvolvimento, o ápice radicular perdeu seu formato original "afilado", adquirindo um aspecto mais "achatado", devido ao incremento na diferenciação de células parenquimáticas, agora em contato direto com o núcleo de células meristemáticas apicais (Figuras 9C e 10C). A análise em maior detalhe do MAR competente para conversão (isolado de raízes de plantas com 120 dias de idade) reforçou a idéia da redução do número de células que o compunham e de seu posicionamento vizinho às regiões 
já diferenciadas do ápice. Além disso, o padrão de organização encontrado nesse período do desenvolvimento pareceu equivaler ao MAR do tipo intermediário-aberto, ou seja, já não era mais possível verificar na região central do ápice uma delimitação nítida entre o meristema fundamental e as células da coifa. A protoderme, por sua vez, pareceu já ter sido extinta devido à diferenciação de suas células em epiderme, a qual foi identificável apenas nas regiões mais laterais do ápice radicular (Figura 10C).

Por fim, os ápices radiculares isolados de plantas com 240 dias de idade mostraramse profundamente modificados, não sendo mais possível identificar um padrão de organização característico do MAR detectado nos ápices mais jovens, inclusive com o desaparecimento da coifa. Nesse material verificou-se uma intensa diferenciação não só do córtex, cilindro vascular, velame, entre outros tecidos; mas também que boa parte do próprio meristema fundamental diferenciou-se em células parênquimáticas (Figura 9D).

Análises mais detalhadas dessa região mostraram que imerso na região central do parênquima formado dentro do antigo MAR encontraram-se grupos de células com características ainda meristemáticas, as quais não apresentaram uma organização muito bem definida (Figura 10D e 12B). Fazendo parte de um desses grupos celulares, com posição mais apical, foi possível distinguir a presença de células com núcleos bem evidentes e citoplasmas mais densos (indicado com seta vermelha na imagem). Esse grupo de células apresentou conteúdo protéico relativamente mais elevado que o restante das células ao seu redor em estágio de diferenciação mais avançado (Figura 12C), ao passo que em ápices radiculares jovens, isolados de plantas com 30 dias de idade, a marcação das proteínas esteve presente em todas as células do MAR (Figura 12D).

No MAR mais velho verificou-se um segundo grupo de células, em posicionamento mais subapical em relação ao primeiro, o qual também apresentou células com núcleos grandes, no entanto, os citoplasmas destas apresentaram-se ligeiramente mais vacuolados em comparação ao primeiro conjunto de células meristemáticas (indicado com seta azul na 
imagem). Esse último grupo de células pareceu fazer ligação entre o cilindro vascular e o primeiro núcleo celular com citoplasmas mais densos (Figura 10D). A localização dessas células meristemáticas presentes na região central do MAR diferenciado em parênquima pareceu coincidir com a localização inicial do CQ em ápices de raízes jovens (Figura 12B). 

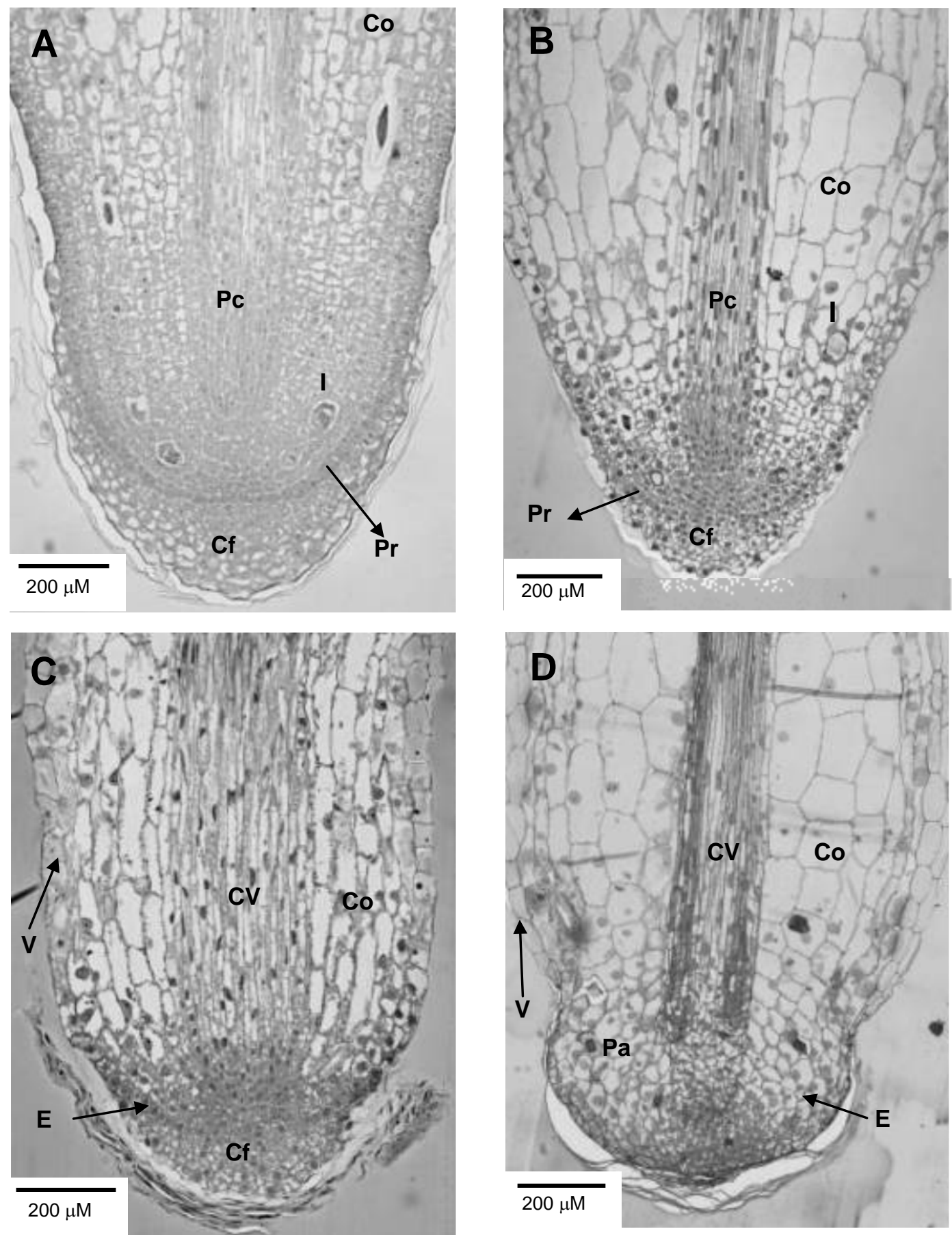

Figura 9: Cortes longitudinais de ápices radiculares recém-isolados de plantas de $C$. fimbriatum com diferentes idades: (A) 30 dias de idade; (B) 60 dias de idade; $(C) 120$ dias de idade e (D) 240 dias de idade. Notar a substancial tendência à diferenciação celular durante 0 envelhecimento do ápice radicular, aumentando a proximidade da zona de diferenciação em relação ao MAR. Pc (procâmbio), Co (córtex), Cf (coifa), Pr (protoderme); I (idioblasto); V (velame), Pa (parênquima), E(epiderme) e CV (cilindro vascular). 

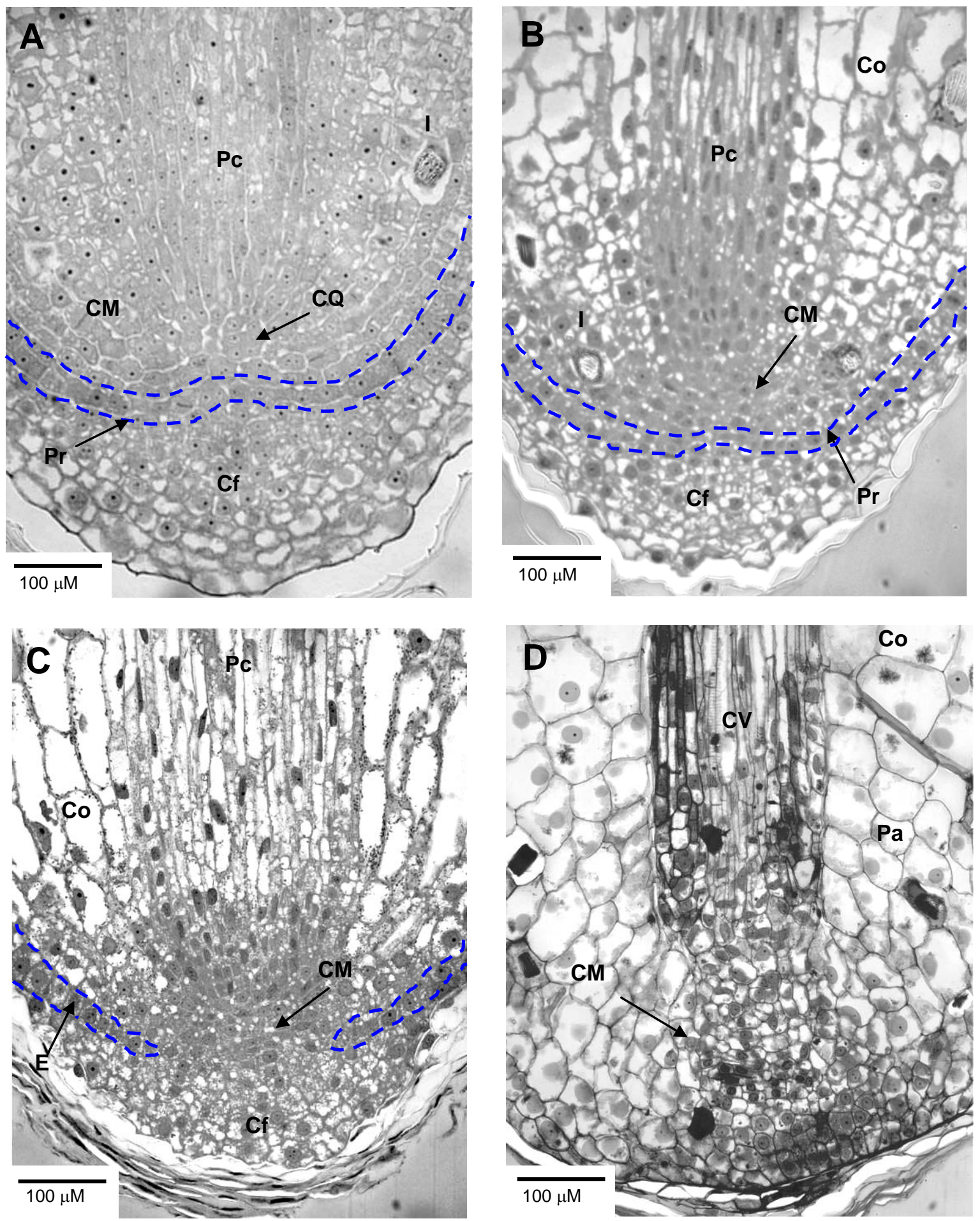

Figura 10: Detalhe da região do MAR em cortes longitudinais de ápices radiculares recémisolados de plantas de C. fimbriatum com diferentes idades: (A) 30 dias de idade; (B) 60 dias de idade; (C) 120 dias de idade e (D) 240 dias de idade. Linha tracejada em azul delimita as células da protoderme. Pc (procâmbio), Co (córtex), Cf (coifa), Pr (protoderme), I (idioblasto), $\mathrm{Pa}$ (parênquima), CV (cilindro vascular), E (epiderme) e CM (células meristemáticas). 

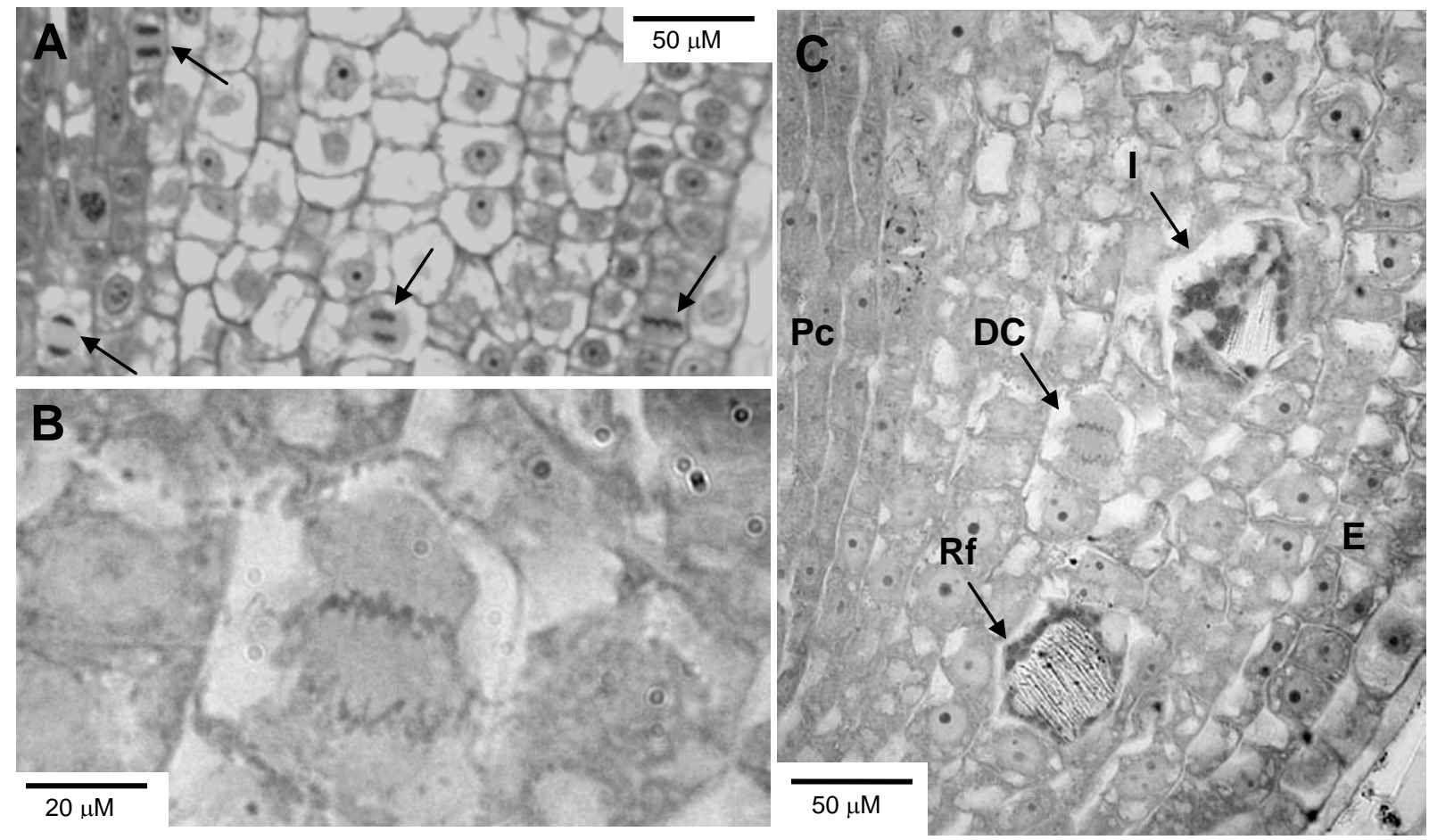

Figura 11: Detalhes celulares do ápice radicular recém-isolado de plantas com 30 dias de idade: $(A)$ setas indicam presença de figuras mitóticas; $(B)$ detalhe de divisão celular $(D C) ;(C)$ presença de idioblastos em diferenciação e de divisões celulares (DC) em regiões vizinhas dentro do meristema fundamental. Pc (procâmbio); $E$ (epiderme); I (idioblastos) e Rf (ráfides no interior dos idioblastos).
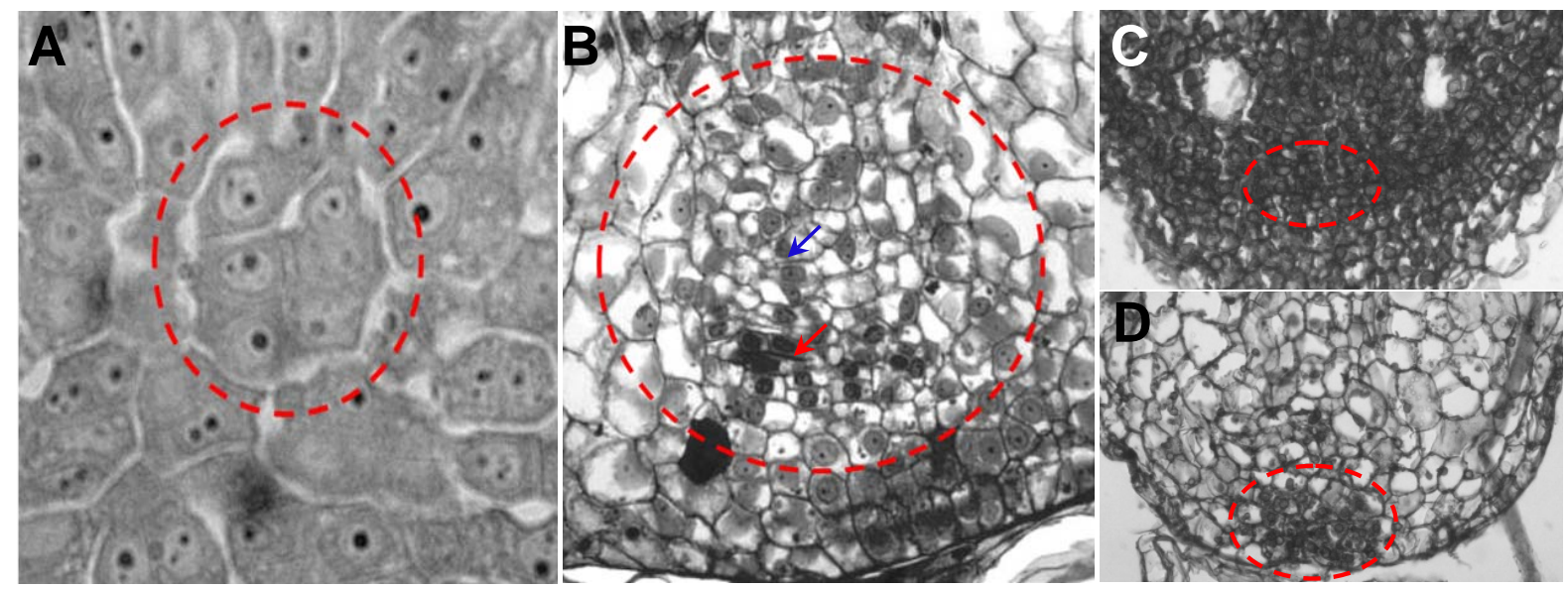

Figura 12: Detalhes da região do centro quiescente (CQ) de ápices radiculares recémisolados de plantas com ( $A$ e C) 30 dias e (B e D) 240 dias de idade. Sendo que (A) e (B) materiais corados com azul de toluidina; $(C)$ e $(D)$ análises histoquímica do conteúdo de proteínas. Os círculos vermelhos indicam a localização do $C Q$ ou região equivalente dentro do MAR. Seta vermelha e seta azul indicam conjuntos celulares com menor e maior nível de diferenciação, respectivamente. 
Modificações na morfologia externa de ápices radiculares competentes após o isolamento da planta-mãe

Com base no acima exposto e no fato de ápices radiculares isolados da planta-mãe serem capazes de se converter em gemas quando incubados em meio de cultura básico, buscou-se compreender quais alterações morfológicas visíveis a olho nu ocorreriam após o isolamento da região apical das raízes já sem crescimento, bem como o tempo dispendido pelo processo de conversão do MAR em gemas caulinares.

Dessa forma, para esse conjunto experimental, optou-se pela utilização de ápices radiculares de plantas com 120 dias de idade como explantes, diante do fato de que já com essa idade a maioria das raízes apresentava ápices suficientemente competentes para a conversão após o isolamento (Figuras 4C e 4D), porém não tinham atingido uma modificação do MAR extremada, como observado nos ápices de raízes de plantas com 240 dias de idade (Figura 10D).

Verificou-se que a conversão de ápices radiculares em gemas caulinares é um evento organogênico complexo que envolve várias fases de modificações na região apical dos explantes (Figuras 13A - 13C) que culmina com o estabelecimento de uma gema (Figura 13D), a qual origina, por sua vez, uma nova planta com seus primórdios caulinares e radiculares (Figura 13E).

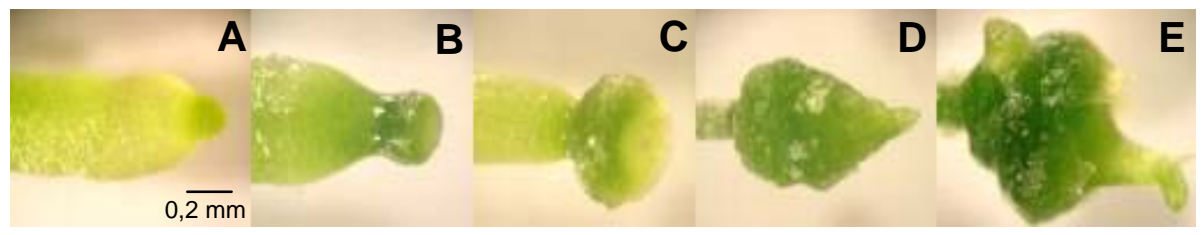

Figura 13: Sequiência de modificações próprias da organogênese ocorridas na região meristemática de explantes isolados de plantas de C. fimbriatum com 120 dias de idade. Aspecto morfológico do ápice radicular após diferentes períodos de isolamento: (A) ápice radicular recém-isolado; (B) após 5 dias do isolamento; $(C)$ após 10 dias do isolamento; (D) após 20 dias do isolamento e (E) após 30 dias do isolamento. 
A constatação a olho nu do desencadeamento desse processo foi possível quando se observou as alterações externas na região do MAR dos explantes após cerca de 5 dias do isolamento (Figura 13B), se tornando mais claras quando os ápices radiculares permaneceram por cerca de 10 dias isolados (Figura 13C).

As alterações da região meristemática após o isolamento dos explantes foram associadas ao intumescimento conspícuo da região do MAR (Figura 14A), sendo que esse momento pareceu tornar o processo de conversão do MAR em gemas caulinares irreversível, sob as condições ora estabelecidas para as análises. Observou-se que a formação da gema caulinar ocorreu a partir do MAR intumescido, sendo que a nova planta formada a partir desse processo tornou-se independente do explante radicular que a originou logo após a formação de suas próprias estruturas caulinares e radiculares (Figura 14B).
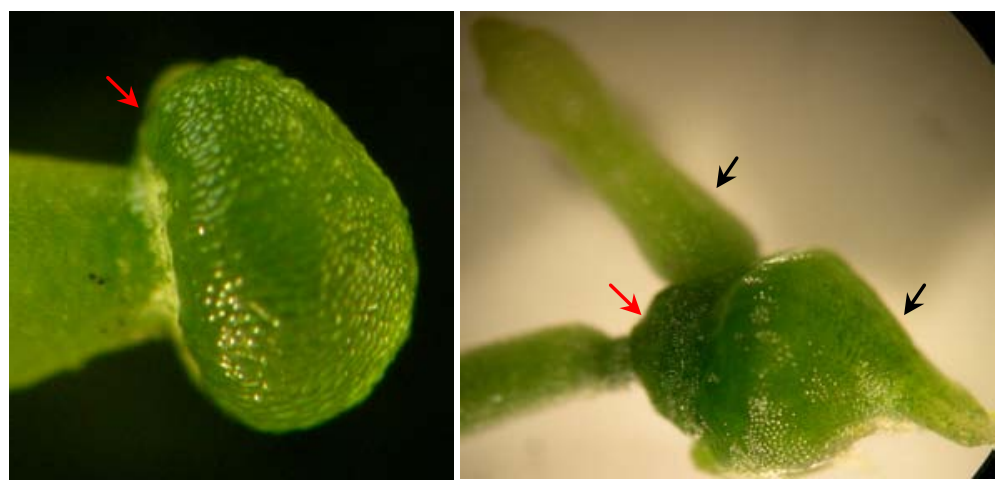

Figura 14: Detalhes de duas fases da transformação do meristema apical radicular (MAR) após o isolamento dos ápices radiculares de plantas de C. fimbriatum com 120 dias de idade. (A) MAR intumescido após o 10 dias de isolamento dos ápices radiculares; (B) parte caulinar e radicular da nova planta formada a partir da região meristemática intumescida dos explantes incubados por 30 dias. Setas vermelhas indicam o MAR intumescido e setas pretas indicam os primórdios caulinar e radicular da nova planta formada a partir da conversão do MAR. 
Modificações histológicas nos ápices radiculares competentes após o isolamento da planta$\underline{\text { mãe }}$

Com o objetivo de compreender melhor o processo que leva à conversão do MAR em gemas caulinares, realizaram-se análises histológicas de ápices radiculares isolados de plantas com 120 dias de idade, os quais foram submetidos a diferentes períodos de isolamento em meio de cultura básico. Essas análises revelaram que o MAR de ápices radiculares isolados apresentou mudanças visíveis na sua organização já nas primeiras horas após a separação da planta-mãe (Figura 15).

Comparando com os ápices radiculares recém-isolados (Figura 15A), verificou-se que após 12 horas do isolamento ocorreu o início de modificações na organização do MAR, não sendo mais possível distinguir os limites das regiões correspondentes ao CQ, protoderme, coifa e células iniciais do córtex (Figura 15B). Dessa forma, esse conjunto de alterações indicou que a organização inicial do MAR recém-isolado (intermediário-aberto) (Figura 15A) mudou para uma organização de MAR tipicamente aberto após 12 horas de isolamento dos explantes (Figura 15B). Além disso, ao final desse período, o MAR era constituído por células meristemáticas com citoplasmas aparentemente menos densos (mais vacuolados) do que o MAR do explante recém-isolado (Figuras 15A e 15B).

Após 24 horas de incubação as células meristemáticas apresentavam-se ainda com citoplasmas mais vacuolados e com a estrutura do MAR aparentemente aberta. A maioria das células da coifa, por sua vez, não continha núcleos evidentes, indício de que já estariam mortas ou a caminho de morte celular programada. Verificou-se também o início de destacamento das células laterais da coifa (Figura 15C). Ao longo das $36^{\circ}$ e $48^{\circ}$ horas seguintes ao isolamento, tiveram-se a continuidade dos processos detectados na $24^{\mathrm{a}}$ hora, no entanto, com uma acentuada regressão da coifa (Figura 15D), chegando a desaparecer na $48^{\mathrm{a}}$ hora de isolamento (Figura 15E). 
Segundo o que é dado observar após 10 dias do isolamento da planta-mãe, foi notório o estabelecimento de uma nova organização estrutural do ápice radicular, protagonizado pelo amplo intumescimento dessa região (Figuras 15F e 16A). Esse novo padrão de organização parece ter sido derivado da expansão de parte das células do MAR, originando tecido parenquimático, bem como pela divisão de um conjunto de células que se mantiveram com características meristemáticas (Figura 15F). Foi possível identificar na borda dessa estrutura a organização de uma epiderme e o início do estabelecimento de um meristema apical caulinar característico, já com um primórdio de gema, bem como o início da diferenciação de cordões procambiais que fizeram ligação da gema em formação e o cilindro vascular do explante inicial (Figura 16). 

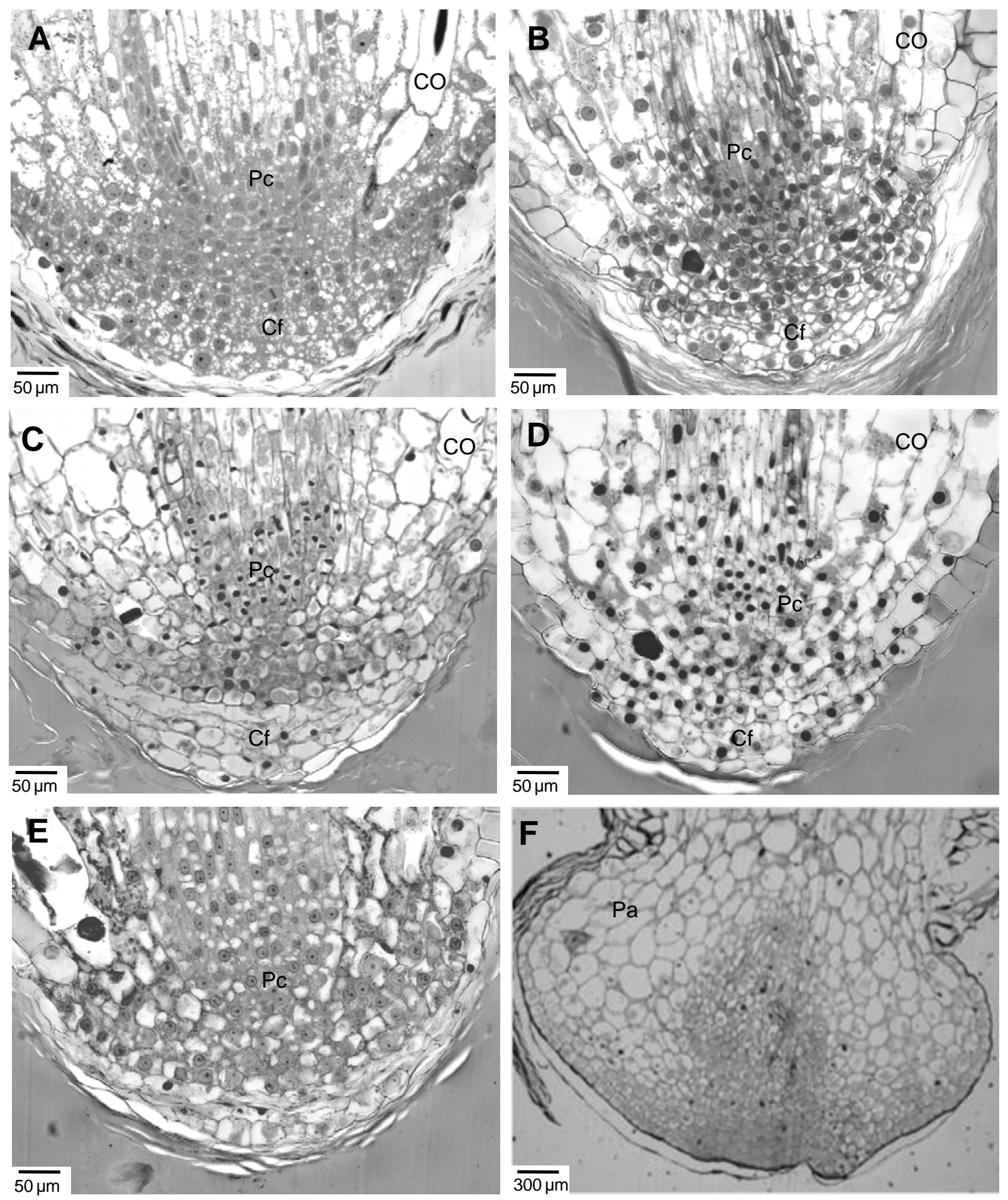

Figura 15: Cortes longitudinais de ápices radiculares de $C$. fimbriatum isolados de plantas com 120 dias de idade submetidos a diferentes períodos de incubação: $(\boldsymbol{A})$ material recémisolado; (B) após 12 horas de incubação; $(C)$ após 24 horas; $(D)$ após 36 horas; $(E)$ após 48 horas e (F) após 10 dias de incubação. PC (procâmbio), CO (córtex), Cf (coifa) e Pa (parênquima). 

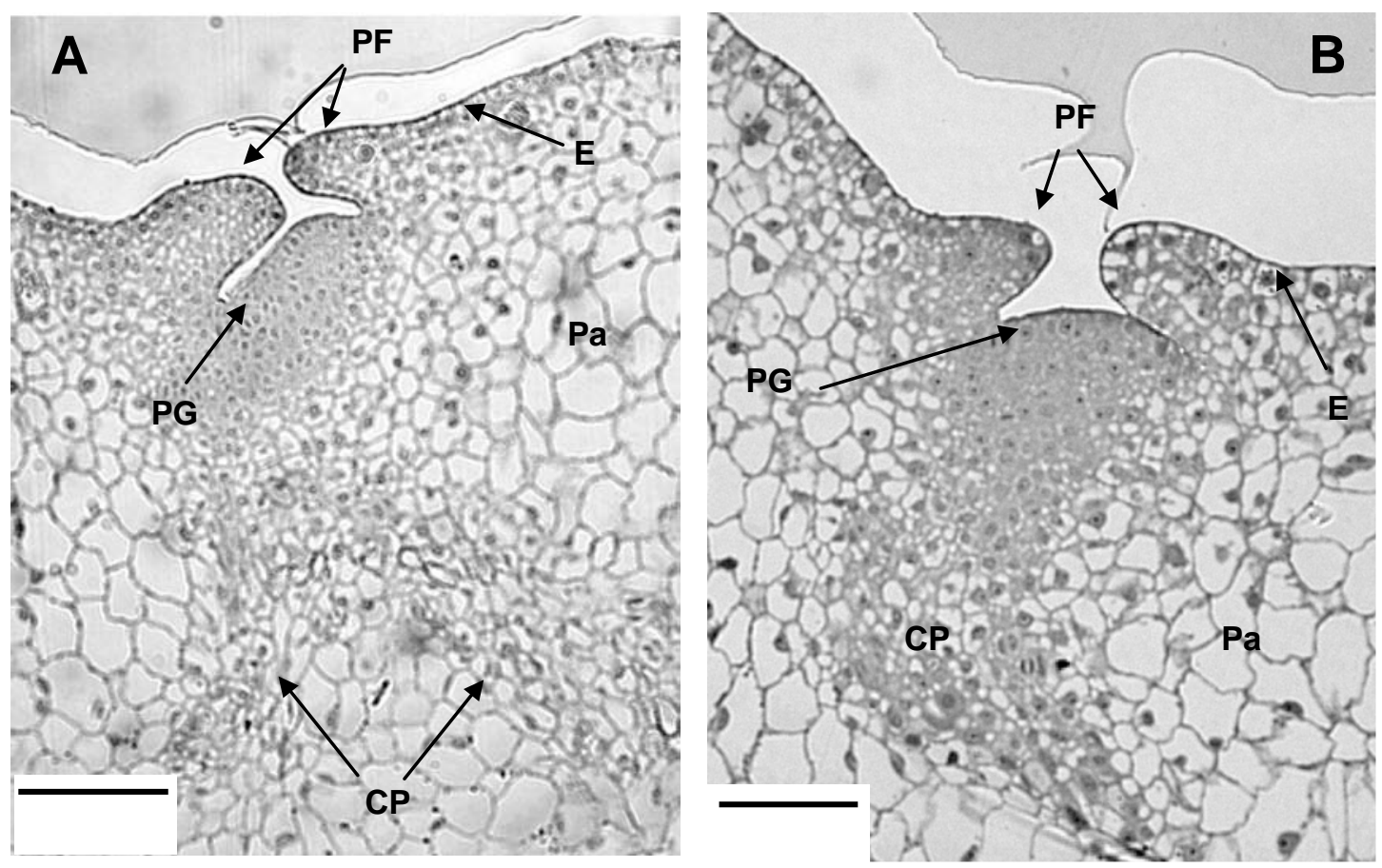

Figura 16: Cortes longitudinais de ápices radiculares isolados de plantas de C. fimbriatum com 120 dias de idade e incubados por 10 dias sob luz branca. (A) detalhe do plano de divisões celulares para formação de epiderme e a gema; (B) primórdio de gema caulinar com cordões procambiais. Co (córtex), Pa (parênquima); CM (células meristemáticas), CP (cordões procambiais), PG (primórdio de gema), PF (primórdios foliares) e V (velâmen).

\section{IV.2. Papel das citocininas na aquisição de competência}

$\underline{\text { Teores endógenos de citocininas em ápices radiculares durante o envelhecimento }}$

A quantificação dos teores endógenos das citocininas zeatina (Z), zeatina ribosídica (ZR), isopenteniladenina (iP) e isopenteniladenosina (iPR) em ápices radiculares competentes e não-competentes para conversão em gemas revelou que o processo de ganho de competência coincidiu com a diminuição em cerca de 38\% no conteúdo total das citocininas analisadas (Figura 17A).

Observou-se ainda que em ambos tipos de ápices radiculares recém-isolados o tipo de citocinina isopenteniladenina (iP + iPR) predominou com quase o dobro da concentração observada para o tipo de citocinina zeatina $(Z+Z R)$. O tipo isopenteniladenina foi o que mais 
diminuiu com o envelhecimento dos ápices radiculares ainda ligados às plantas, comparativamente com a tendência discreta de queda observada nos teores de citocininas do tipo zeatina (Figura 17B).
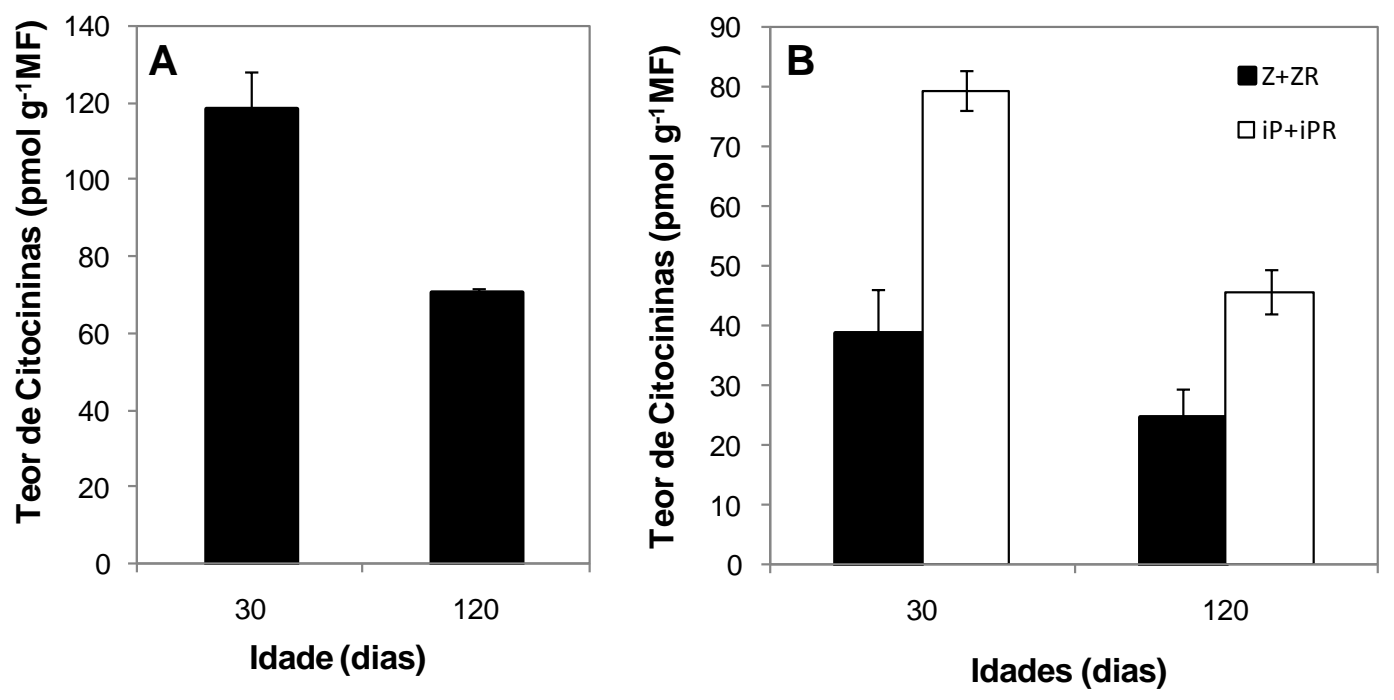

Figura 17: Teores de citocininas em ápices radiculares isolados de plantas de $C$. fimbriatum com 30 (não-competentes) e 120 dias de idade (competentes para conversão do MAR em gemas caulinares). (A) citocininas totais (iPR + iP + ZR + Z); (B) citocininas do tipo isopenteniladenina (iPR+iP) e do tipo zeatina $(Z R+Z)$. Barras de erro indicam erro padrão.

O processo de ganho de competência pareceu também contar com um controle fino das formas de citocininas, uma vez que se observou uma predominância diferenciada de isômeros ópticos de ZR em explantes com diferentes respostas à organogênese; ápices radiculares não-competentes para conversão apresentaram teores mais elevados de $c$-ZR, ao passo que os competentes apresentaram a predominância de $t$-ZR (Figura 18). 


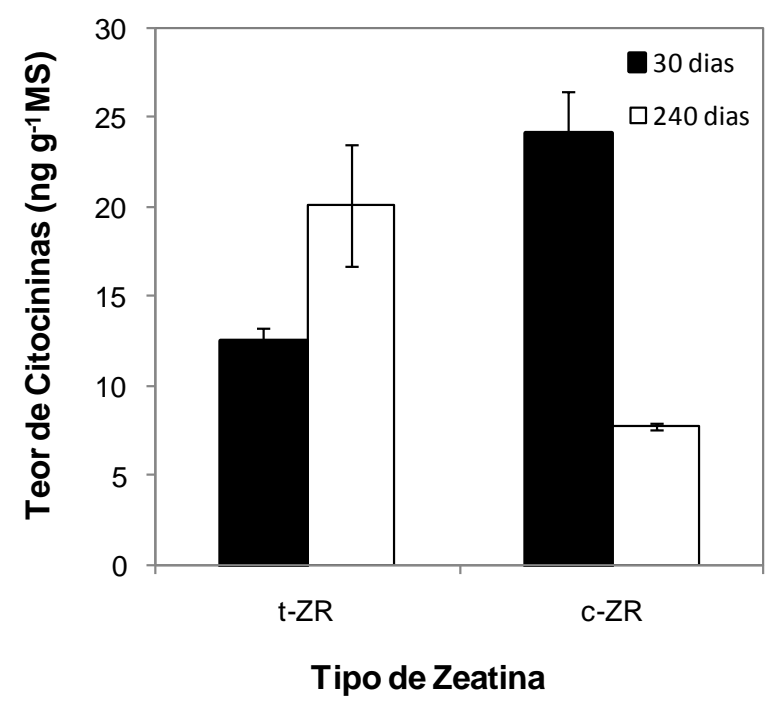

Figura 18: Teores de isômeros ópticos cis e trans de zeatina ribosídeo ( $c-Z R$ e $t-Z R$, respectivamente) em ápices radiculares isolados de plantas de $C$. fimbriatum com 30 (nãocompetentes) e 240 dias de idade (competentes para conversão do MAR em gemas caulinares). Barras de erro indicam erro padrão.

Efeitos das citocininas sobre a aquisição de competência para conversão de ápices radiculares em gemas caulinares

O tratamento de ápices radiculares não-competentes (isolados de plantas com 30 dias de idade) com diferentes tipos de citocininas revelou que Z e ZR proporcionaram a inibição do crescimento longitudinal dos explantes jovens em cerca de 80 e 67\%, respectivamente. Por outro lado, tanto iP quanto iPR também inibiram o crescimento dos explantes jovens, porém em cerca de 33\% (Figura 19A e 20A).

Complementarmente, tratamentos com Z, ZR, iP e iPR propiciaram a conversão em cerca de 83; 43; 10 e 7\% dos explantes, respectivamente (Figura 19B). Na condição controle esse material não apresentou conversões do MAR em gemas caulinares, mantendo o crescimento longitudinal radicular (Figuras 19B e 20A). As plantas formadas a partir da conversão de ápices radiculares não-competentes e competentes, tratados com citocininas do tipo zeatina apresentaram deficiência no desenvolvimento radicular (Figuras 20A e 20B, respectivamente), ao passo que aquelas originadas a partir da conversão de explantes 
competentes tratados com citocininas do tipo iP apresentaram um maior desenvolvimento radicular e uma ligeira inibição caulinar (Figura 20B).

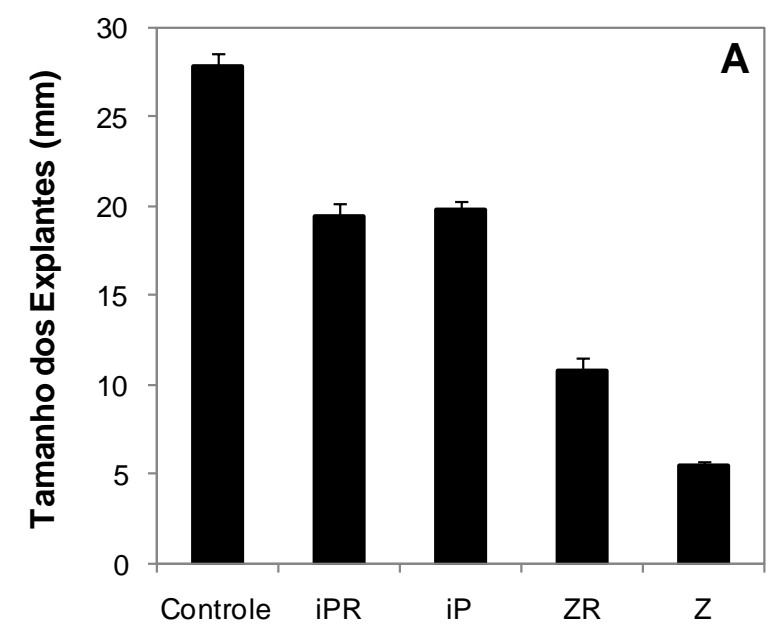

Tipo de Citocinina

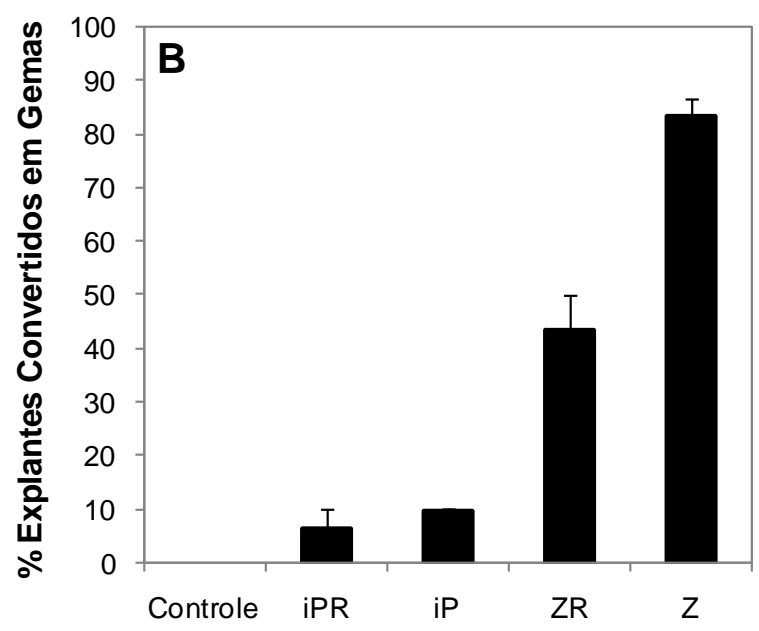

Tipo de Citocinina

Figura 19: Respostas organogênicas de ápices radiculares isolados de plantas de $C$. fimbriatum com 30 de idade e incubados por 30 dias em meio suplementado com $1 \mu M$ de iPR, iP, ZR ou Z: (A) Tamanho final dos explantes; (B) Porcentagem de explantes convertidos em gema caulinar. Barras de erro correspondem ao erro padrão.
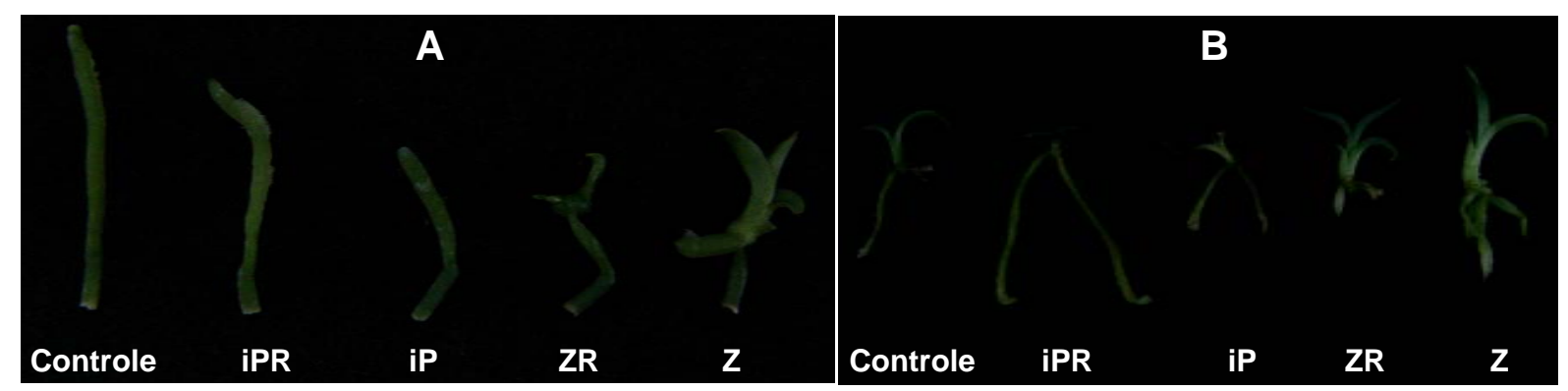

Figura 20: Fenótipo de ápices radiculares de $C$. fimbriatum após 30 dias de incubação na presença de $1 \mu M$ de iPR, iP, ZR ou Z. (A) explantes isolados de plantas com 30 dias de idade (não-competentes) e (B) explantes isolados de plantas com 120 dias de idade (competentes). 
Teores endógenos de citocininas após o isolamento de ápices radiculares competentes

As análises do conteúdo endógeno de citocininas em ápices radiculares que permaneceram em incubação por diferentes períodos de isolamento indicaram que os teores dessa classe hormonal variaram consideravelmente em função desses tratamentos.

Como uma tendência geral observada, verificou-se que os teores endógenos totais das citocininas analisadas $(Z+Z R+i P+i P R)$ caíram rapidamente após o isolamento dos ápices radiculares. Verificou-se que a concentração dessas citocininas permaneceu reduzida em relação ao tempo zero até cerca da $10^{\mathrm{a}}$ hora após o isolamento dos explantes. Por outro lado, após as 12 horas do isolamento pode-se verificar uma tendência de aumento nos teores dessa classe hormonal, os quais praticamente recuperaram as concentrações encontradas no período inicial do experimento (tempo zero) (Figura 21A).

Antes do isolamento dos ápices radiculares da planta-mãe, o tipo de citocininas iP predominava nos explantes, no entanto, após somente duas horas do isolamento, os teores endógenos desse tipo de citocininas caíram de maneira proeminente, não apresentando elevações até a $12^{\mathrm{a}}$ hora. Verificou-se também que os teores endógenos desse tipo de citocinina não retornaram ao valor encontrado inicialmente nos explantes recém isolados (tempo zero) durante todo o período de análise após o isolamento (Figura 21B).

Por outro lado, a queda inicial das citocininas do tipo iP coincidiu com a predominância de citocininas do tipo $Z$ durante a maior parte do período de análise dos explantes. Essa tendência oposta ao que era encontrado nos explantes iniciais se estabeleceu muito rapidamente, logo após as primeiras horas do isolamento dos ápices radiculares e perdurou até a $24^{\mathrm{a}}$ hora de isolamento (Figura 21B). 

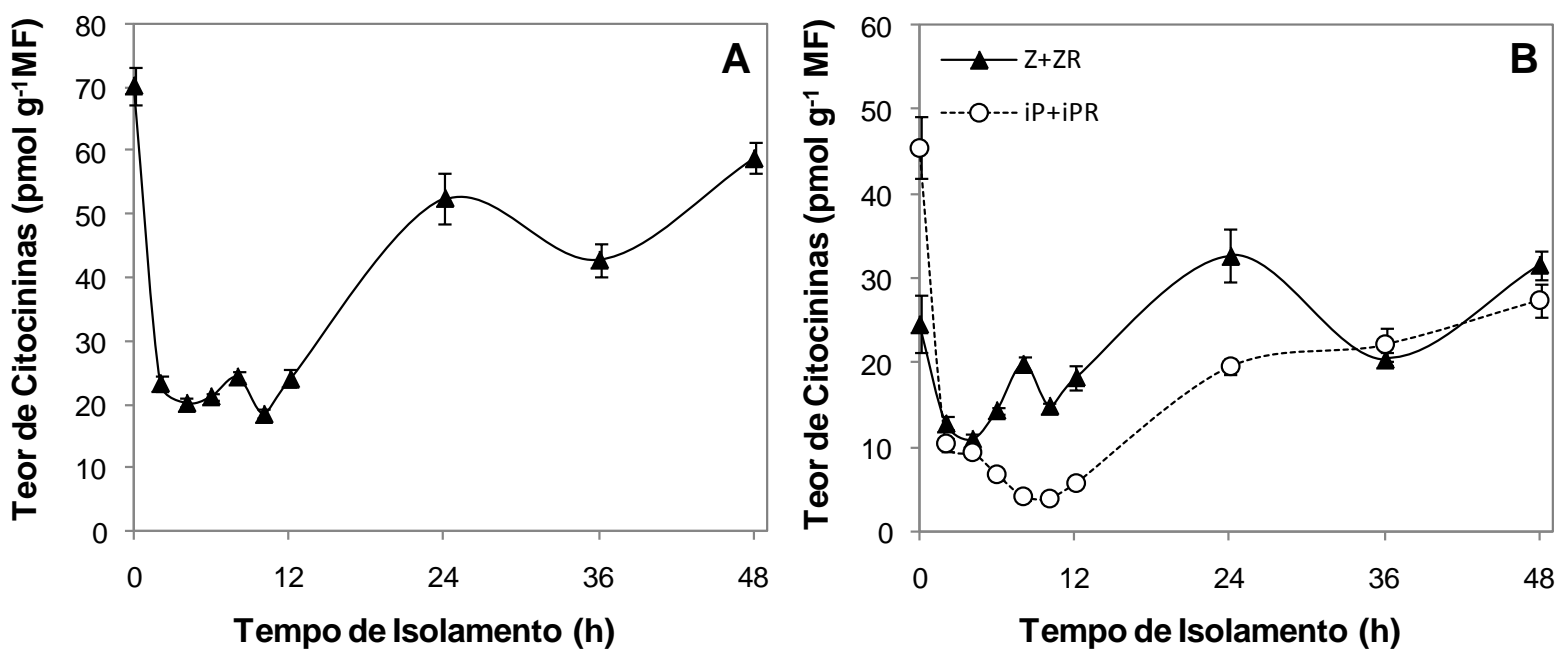

Figura 21: Teores endógenos de citocininas em ápices radiculares isolados de plantas de $C$. fimbriatum com 120 dias de idade, os quais foram submetidos a diferentes períodos de incubação $(0,2,4,6,8,10,12,24,36$ e 48 horas): (A) conteúdo total das citocininas analisadas ( $i P R+i P+Z R+Z) ;(B)$ conteúdo de citocininas do tipo iP (iP+iPR) e do tipo $Z(Z+Z R)$. Barras de erro indicam erro padrão.

Efeito de tratamentos com citocininas em ápices radiculares competentes e isolados

A incubação de ápices radiculares isolados de plantas com 120 dias de idade em meio de cultura suplementado com uma citocinina, nesse caso $0,125 \mathrm{mg} / \mathrm{L}$ de benziladenina (BA), proporcionou uma aceleração nas modificações apicais dos explantes que levam a conversão do MAR em gemas caulinares. Essa aceleração no processo de conversão do MAR em gemas caulinares nos explantes tratados com citocinina exógena foi possível de ser verificada logo nos primeiros cinco dias de incubação dos ápices radiculares (Figura 22).

Segundo apresentado na figura 22, a freqüência de explantes convertidos em gemas foi de $90 \%$ após 10 dias do isolamento e incubação na presença da citocinina exógena, ao passo que no controle foi verificado apenas de $70 \%$ de conversão nesse mesmo período.

Esse efeito promotor da citocinina exógena sobre o processo de conversão do MAR em gemas caulinares pareceu depender da duração do tratamento dos explantes logo após o isolamento das plantas-mãe. A figura 23 mostra que os explantes tratados com pulsos iniciais de 24,36 ou 48 horas de $0,125 \mathrm{mg} / \mathrm{L}$ de $\mathrm{BA}$, quando comparados aos submetidos a apenas 
12 horas, apresentaram tendência a uma maior velocidade e uma maior sincronização das modificações apicais que levam à conversão.

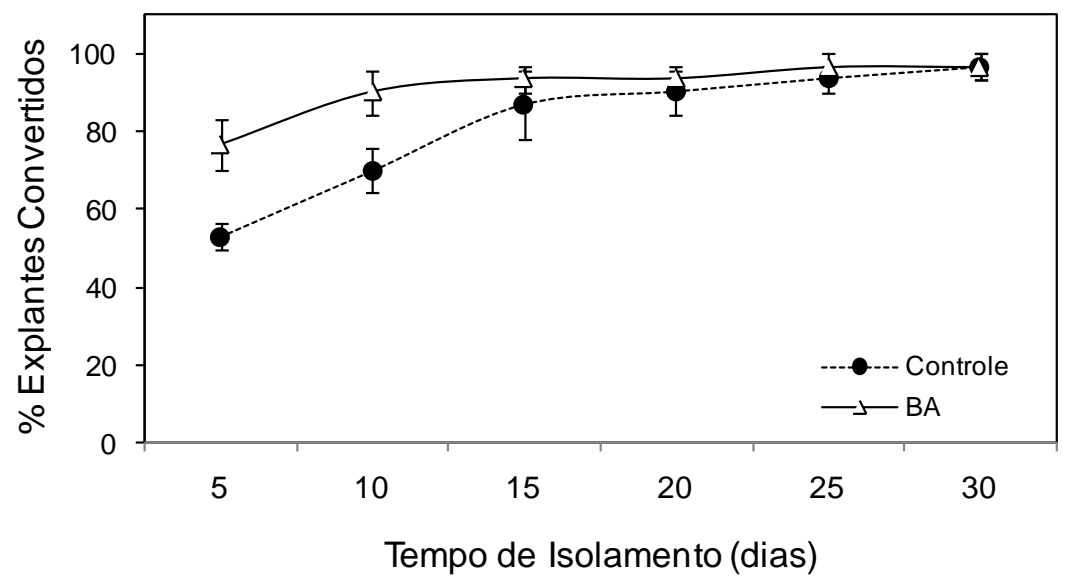

Figura 22: Porcentagem de ápices radiculares isolados de plantas com 120 dias de idade convertidos em gemas caulinares após 5, 10, 15, 20, 25 ou 30 dias de incubação em meio básico, ou suplementado com 0,125mg/L de BA (benziladenina). Barras indicam erro padrão.

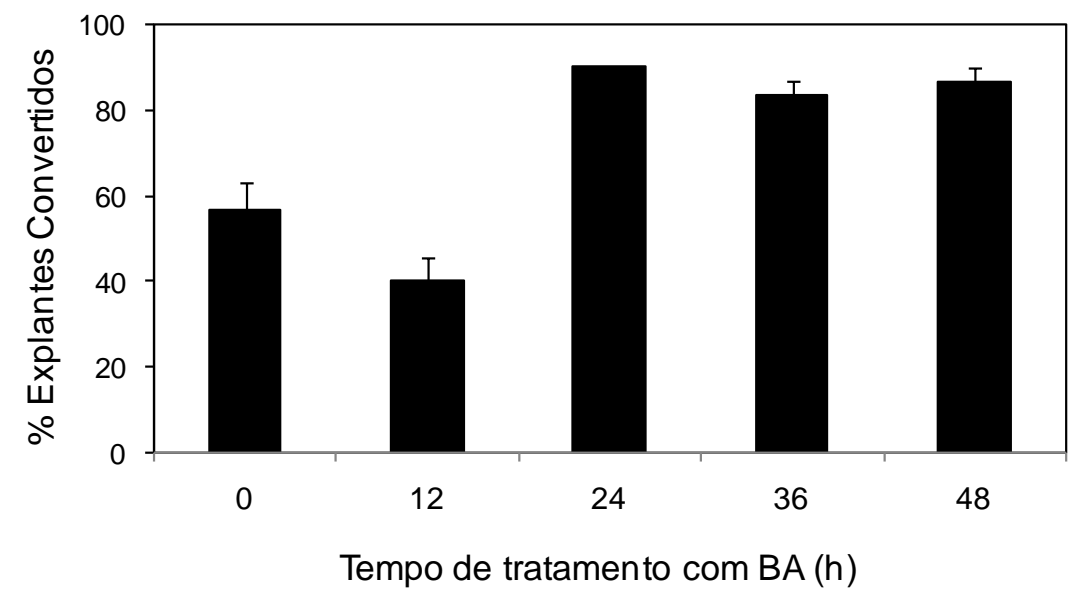

Figura 23: Porcentagem de ápices radiculares isolados de plantas com 120 dias de idade com intumescimento apical após 5 dias de isolamento, sendo estes submetidos inicialmente ao tratamento com $0,125 \mathrm{mg} / \mathrm{L}$ de benziladenina (BA) durante $0,12,24,36$ Ou 48 horas, e transferidos subseqüentemente para meio básico para complementação do tempo de isolamento. Barras indicam erro padrão. 
Efeitos das citocininas sobre o desenvolvimento de ápices radiculares competentes ligados à planta-mãe

A transferência de plantas intactas com 240 dias de idade para meio novo de crescimento, evidenciou que a renovação das condições de cultivo in vitro foi suficiente para induzir a retomada do crescimento de parte das raízes, mesmo após estas ter atingido o crescimento determinado sob as condições antigas de cultura (Tabela 3 e Figuras 24A e 24B). Por outro lado, na presença de $1 \mu \mathrm{M}$ de zeatina não foi observada a retomada de crescimento em nenhum dos ápices radiculares, ao contrário disso, parte das raízes teve o MAR convertido em gema caulinar (Tabela 3 e Figura 24A, 24B e 24D). A inoculação de ápices radiculares isolados de plantas com 240 dias de idade em meio de cultura suplementado com $1 \mu \mathrm{M}$ de zeatina não proporcionou modificações significativamente distintas em relação à proporção de explantes convertidos em gemas caulinares na condição controle. Nesse tratamento também não foi visualizada retomada de crescimento de ápices radiculares (Tabela 3 e Figura 24C). Observou-se também a inibição do desenvolvimento do sistema radicular das plantas formadas a partir dos explantes incubados na presença de zeatina (Figura 24C)

Tabela 3: Respostas organogênicas de ápices radiculares isolados ou ligados a plantas intactas de C. fimbriatum com 240 dias de idade. Os dois tipos de materiais foram inoculados em meio novo de Vacin e Vent (1949 - modificado conforme descrito no item III.2.2) suplementado e não suplementado com $1 \mu \mathrm{M}$ de zeatina, onde foram incubados por 30 dias. Junto aos valores médios encontram-se os respectivos erros-padrão.

\begin{tabular}{lcc}
\hline \multicolumn{1}{c}{ Tratamentos } & \% Crescimento Radicular Retomado & \% Conversão \\
\hline Controle (plantas) & $5,10 \pm 0,19$ & 0 \\
\hline $1 \mu \mathrm{M}$ Zeatina (plantas) & 0 & $5,53 \pm 1,63$ \\
\hline Controle (explantes) & 0 & $83,33 \pm 3,34$ \\
\hline $1 \mu \mathrm{M}$ Zeatina (explantes) & 0 & $76,67 \pm 3,34$ \\
\hline
\end{tabular}




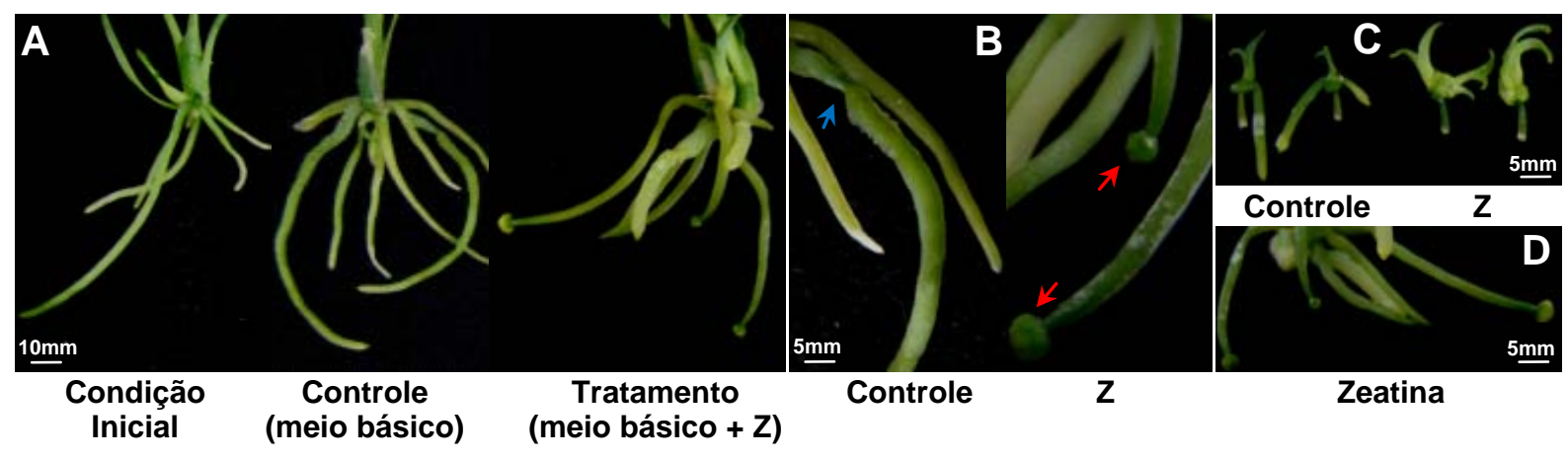

Figura 24: Formação de gemas em ápices radiculares isolados ou ligados a plantas de $C$. fimbriatum com 240 dias de idade, os quais foram submetidos a 30 dias de incubação em novo meio de cultura suplementado ou não com $1 \mu M$ de $Z$ : (A) Fenótipo do sistema radicular de plantas com 240 dias de idade antes da transferência para o meio novo (condição inicial), bem como na ausência (controle) e na presença de Z (tratamento); (B) Detalhe da retomada do crescimento radicular em raízes de plantas transferidas para meio de cultura novo (indicado por seta azul) e da conversão do MAR em gemas caulinares na presença de $Z$ (indicados por setas vermelhas); (C) Aspecto morfológico de ápices radiculares competentes $e$ isolados que apresentaram converaão em gemas após o período de incubação na ausência (controle) e na presença de $Z$ e (D) Aspecto do sistema radicular de plantas intactas após tratamento com $Z$.

\section{IV.3. Papel da auxina na aquisição de competência}

Teores endógenos de auxinas em ápices radiculares durante a aquisição de competência

A quantificação dos teores endógenos da forma livre de AIA (ácido indolilacético) e da sua forma conjugada AIA-Asp (AIA-aspartato) revelou que o envelhecimento radicular resultou em uma diminuição significativa nos teores endógenos de ambas as formas de auxina analisadas nos ápices radiculares de C. fimbriatum. Complementarmente, os teores de AIA foram superiores em relação aos de AIA-Asp nas duas condições estudadas, ou seja, tanto nos ápices radiculares competentes quanto nos não competentes para conversão em gemas caulinares (Figura 25). 


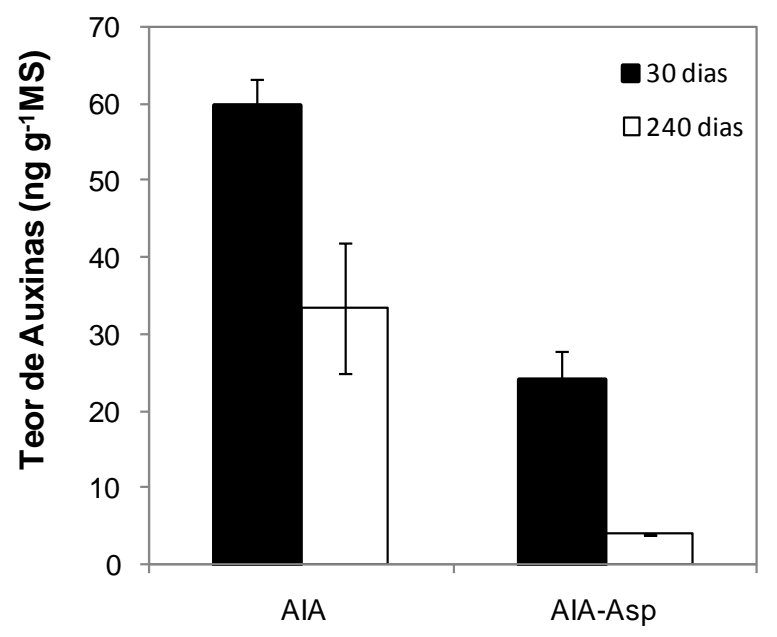

Tipo de Auxina

Figura 25: Teores endógenos da forma livre ácido indolilacético (AIA) e da forma conjugada AIA-aspartato (AIA-Asp) em ápices radiculares isolados de plantas com 30 e 240 dias de idade. Barras de erros indicam erro padrão.

\section{Efeitos da inibição do transporte polar de auxina sobre o crescimento radicular}

A aplicação de NPA (ácido N-1-naftilftalâmico), um inibidor de transporte polar de auxina, em plantas intactas de $C$. fimbriatum com 30 dias de idade resultou numa redução significativa da taxa de crescimento da primeira raiz formada em cada planta (Figura 26). Mesmo as concentrações mais baixas utilizadas (10 e 100 $\mu \mathrm{M})$ foram suficientes para causar uma redução de cerca de $65 \%$ na taxa de crescimento radicular logo na primeira semana de incubação, não sendo observado incremento significativo na taxa de crescimento das raízes até o momento da parada completa do crescimento longitudinal, o qual ocorreu por volta do $65^{\circ}$ dia de incubação (Figura 26).

O tratamento com $1000 \mu \mathrm{M}$ de NPA, por sua vez, mostrou-se totalmente inibitório ao crescimento das raízes, uma vez que o pouco crescimento observado em alguns indivíduos nas duas semanas iniciais não foi considerado significativamente distinto dos pontos em que não se verificou nenhum crescimento das raízes (Figura 26). Essa concentração inibiu também a formação de novas raízes adventícias nas plantas (Figura 27). 


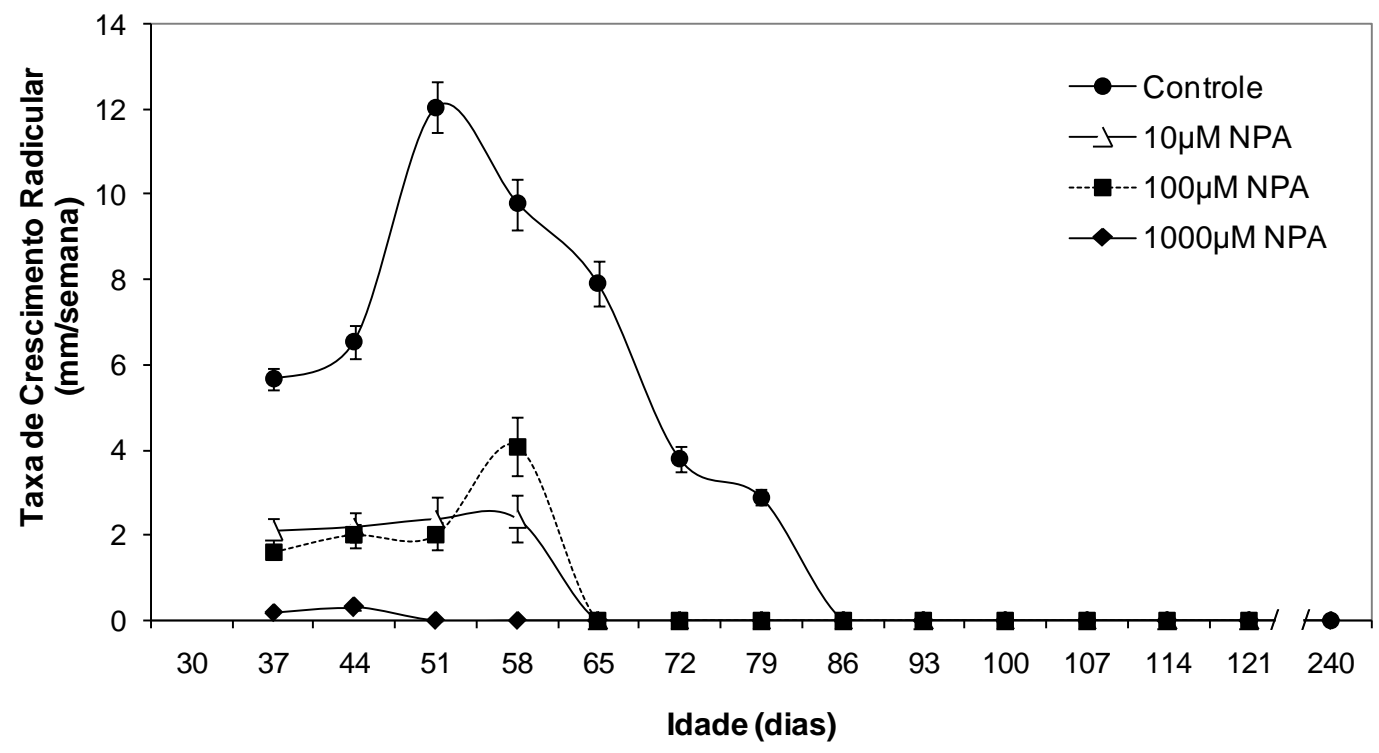

Figura 26: Taxa de crescimento semanal ( $\mathrm{mm} / \mathrm{semana}$ ) da primeira raiz de plantas de $C$. fimbriatum a partir do $30^{\circ}$ dia de idade, as quais foram submetidas a tratamentos com 0; 10; 100 ou $1000 \mu M$ de NPA (ácido N-1-naftilftalâmico). As barras de erro indicam o erro padrão.
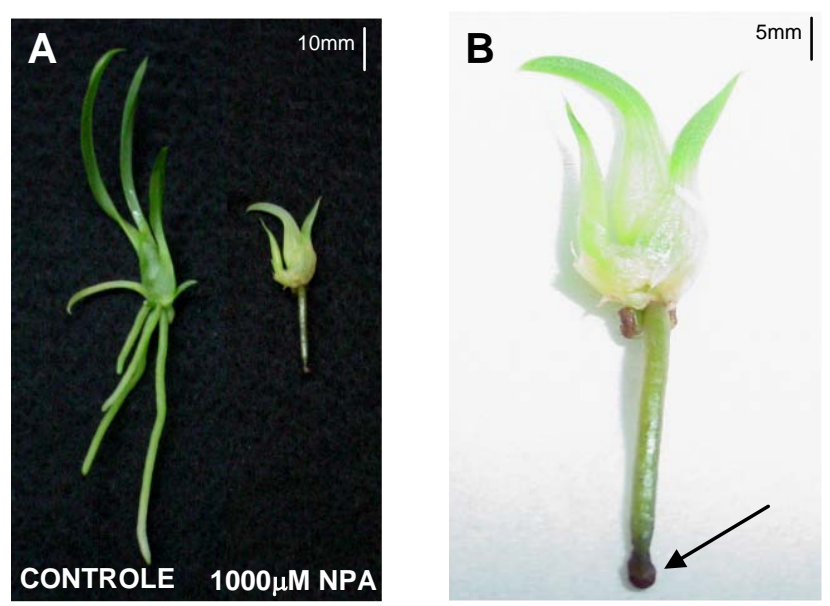

Figura 27: Fenótipo de plantas de C. fimbriatum com 60 dias de idade após tratamento por 30 dias com NPA (ácido N-1-naftilftalâmico): (A) à esquerda planta controle, a qual permaneceu por 60 dias em meio básico, e à direita planta que foi transferida com 30 dias de idade para 0 tratamento com $1000 \mu \mathrm{M}$ de NPA por mais 30 dias. (B) Seta indica detalhe do intumescimento do MAR na planta tratada com $1000 \mu$ M de NPA por 30 dias.

A concentração de $1000 \mu \mathrm{M}$ de NPA à medida que causou a inibição total do crescimento radicular também foi capaz de provocar o intumescimento na região apical das 
raízes, no entanto, nenhuma gema caulinar se formou a partir desse intumescimento enquanto o MAR esteve ligado à planta-mãe durante o período experimental (Figura 27B).

\section{Efeitos da inibição do transporte polar de auxina sobre as estrutura interna do MAR}

Plantas de C. fimbriatum jovens com 30 dias de idade tratadas com 10, 100 e 1000 $\mu \mathrm{M}$ de NPA por 10 dias apresentaram a inibição do crescimento longitudinal das raízes que coincidiu com profundas alterações histológicas nos ápices radiculares (Figura 28). Comparando-se com o ápice radicular controle (Figuras 28A e 28B), verificou-se que todas as concentrações de NPA empregadas induziram intensa diferenciação celular nos tecidos que compõe o ápice radicular (Figuras 28C-28H).

Os ápices radiculares mantidos na condição controle apresentaram a organização e as características celulares típicas de meristemas de raízes em crescimento, uma vez que foi possível verificar o arranjo ordenado de fileiras de células pertencentes aos diferentes tecidos, as quais convergiram para as suas respectivas iniciais funcionais no interior do meristema. As células, em geral apresetaram-se pouco diferenciadas (núcleos grandes e evidentes e citoplasma denso e pouco vacuolado) até uma região distante do meristema fundamental (Figuras 28A e 28B).

Por outro lado, os tratamentos com as duas menores concentrações testadas de NPA provocaram uma conspícua diferenciação das células do córtex, cilindro vascular, e epiderme até uma região bem apical das raízes, desencadeando também um ligeiro grau de diferenciação das células que compunham a coifa e o meristema fundamental (células mais vacuoladas). Além da diferenciação celular verificada nas células que compunham os explantes tratados com 10 e $100 \mu \mathrm{M}$ de NPA, verificou-se também uma clara alteração no padrão de organização celular dentro da região meristemática (Figuras 28C-28F).

Os MARs das raízes tratadas com as menores concentrações de NPA passaram a apresentar o padrão de organização celular do tipo aberto, ou seja, uma região meristemática 
com as iniciais funcionais apresentando desorganização estrutural, fazendo com que não fosse mais possível traçar uma delimitação por meio da protoderme na fronteira entre as iniciais funcionais do meristema fundamental e da columela (Figuras 28D-28F). Situação esta oposta às raízes controle que mantiveram o padrão de organização meristemática do tipo fechado (Figura 28D). O bloqueio do transporte polar de auxina ocasionado pela aplicação de $1000 \mu \mathrm{M}$ de NPA intensificou as modificações nos ápices radiculares, sendo que eles se apresentaram destituídos de coifa e com formato intumescido devido à diferenciação de boa parte do meristema fundamental em células parenquimáticas (Figura 28G).

O MAR das raízes tratadas com $1000 \mu \mathrm{M}$ de NPA apresentou uma clara perda de suas características originais, sendo que uma nova organização apical se estabeleceu como resultado, aparentemente, da diferenciação do MAR em sua quase totalidade em células parenquimáticas e da perda da quiescência do centro quiescente (CQ) (Figura 28H). A perda de quiescência do $\mathrm{CQ}$ foi denotada por meio da presença de um conjunto de células localizadas em posição equivalente ao $\mathrm{CQ}$ no antigo MAR, as quais apresentaram características tipicamente meristemáticas (núcleos grandes e evidentes e citoplasma denso e pouco vacuolado) (Figura $28 \mathrm{H}$ ). As células formadas nesse processo pareceram manter contato com o cilindro vascular por meio de outro grupo celular com um grau de diferenciação ligeiramente maior, posicionado no centro do meristema modificado (Figura 28H).

Nenhuma gema caulinar foi formada a partir do ápice radicular intumescido durante o período experimental em que essa estrutura permaneceu ligada às plantas e em incubação na presença de NPA. 


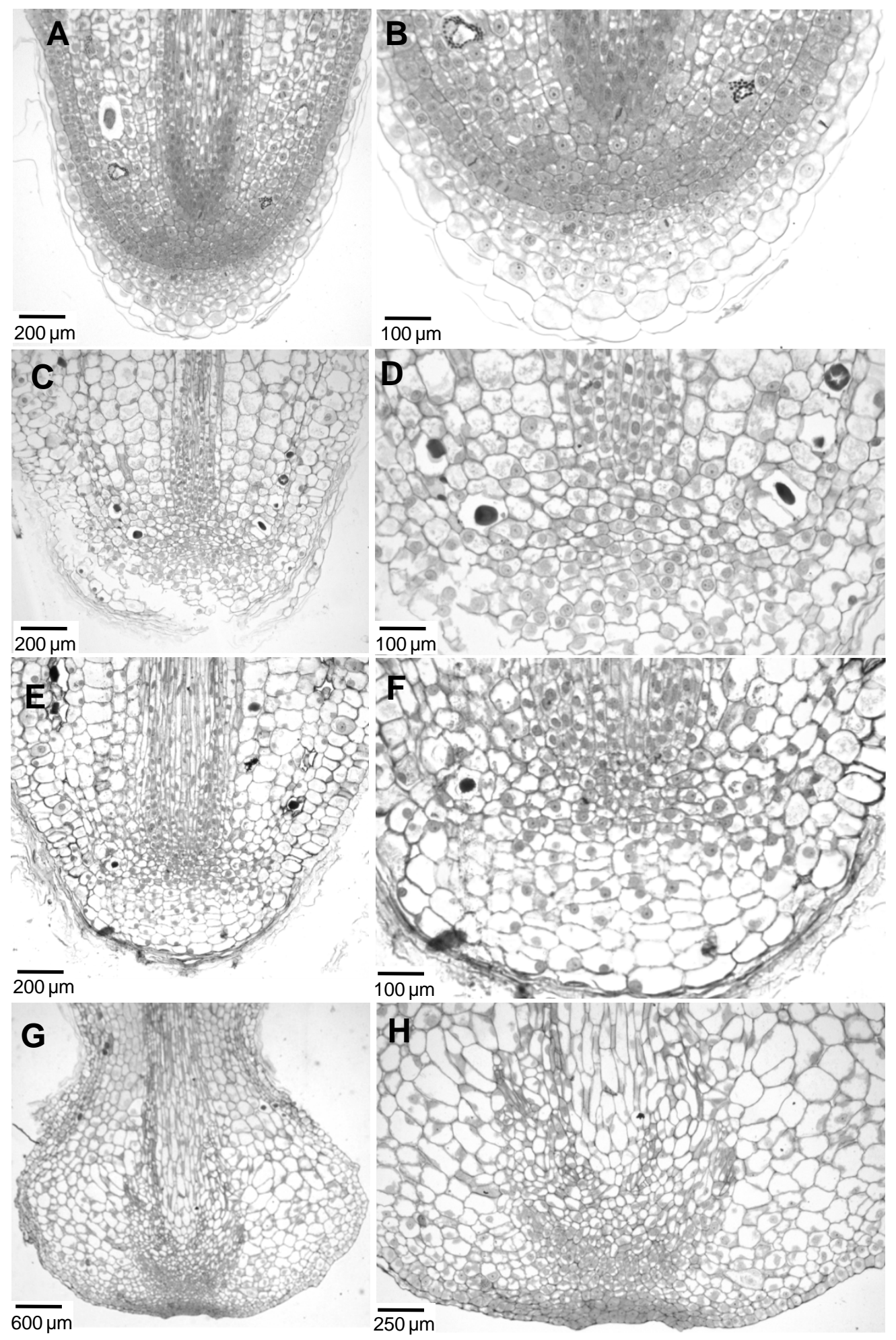

Figura 28: Aspecto do MAR recém-isolado de plantas de C. fimbriatum com 40 dias de idade, submetidas por 10 dias a tratamentos com diferentes concentrações de NPA: $(A)$ e (B) controle, ausência de NPA; (C) e (D) $10 \mu M$ de NPA; (E) e (F) $100 \mu M$ de NPA; (G) e (H) $1000 \mu M$ de NPA, sendo que (A), (C), (E) e (G) mostram o aspecto geral dos ápices radiculares $e(B),(D),(F)$ e $(H)$ mostram detalhe da região do $M A R$. 


\section{Efeitos do NPA sobre os teores endógenos de citocininas nos ápices radiculares}

A aplicação de NPA em plantas jovens de C. fimbriatum não foi capaz de alterar significativamente os teores endógenos das citocininas totais analisadas $(Z+Z R+i P+i P R)$ nos seus ápices radiculares (Figura 29).

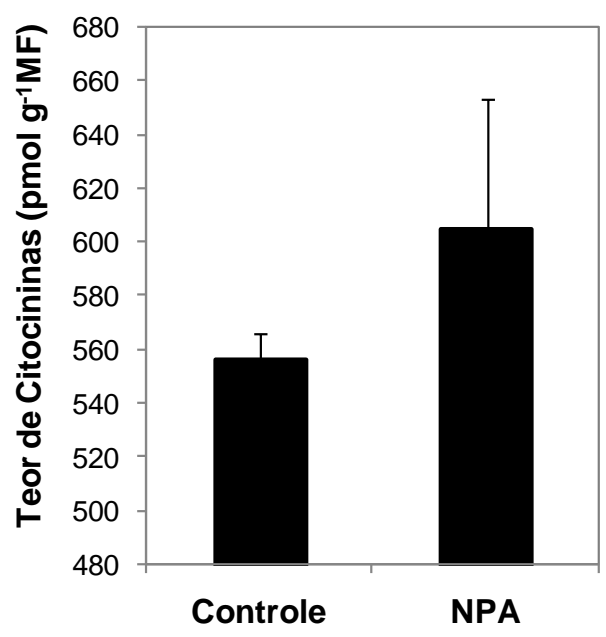

Figura 29: Conteúdo de citocininas totais $(Z+Z R+i P+i P R)$ presente em ápices radiculares de plantas jovens tratadas por 10 dias com $1000 \mu M$ de NPA. Barras indicam erro padrão.

\section{Efeitos do AIA e do NPA sobre o crescimento radicular e a aquisição de competência}

Os tratamentos de ápices radiculares isolados de plantas com 30 dias de idade com diferentes concentrações de NPA ocasionaram a inibição do crescimento longitudinal dos explantes de maneira dose-dependente (Figura 30). Assim como observado no tratamento de plantas intactas (Figura 26), o emprego da concentração mais elevada de NPA (1000 $\mu \mathrm{M})$ mostrou-se totalmente inibitório ao crescimento dos ápices radiculares, uma vez que esses apresentaram o mesmo tamanho inicial (5mm) após 20 dias de incubação (Figura 30).

A aplicação de NPA inibiu o crescimento longitudinal dos explantes por afetar a organização da região meristemática, a qual se mostrou gradativamente mais severa com o aumento da concentração desta substância (Figura 31). O processo de alteração da região 
meristemática culminou no intumescimento do MAR em 100\% dos explantes tratados com a maior concentração de NPA $(1000 \mu \mathrm{M})$ (Tabela 4).
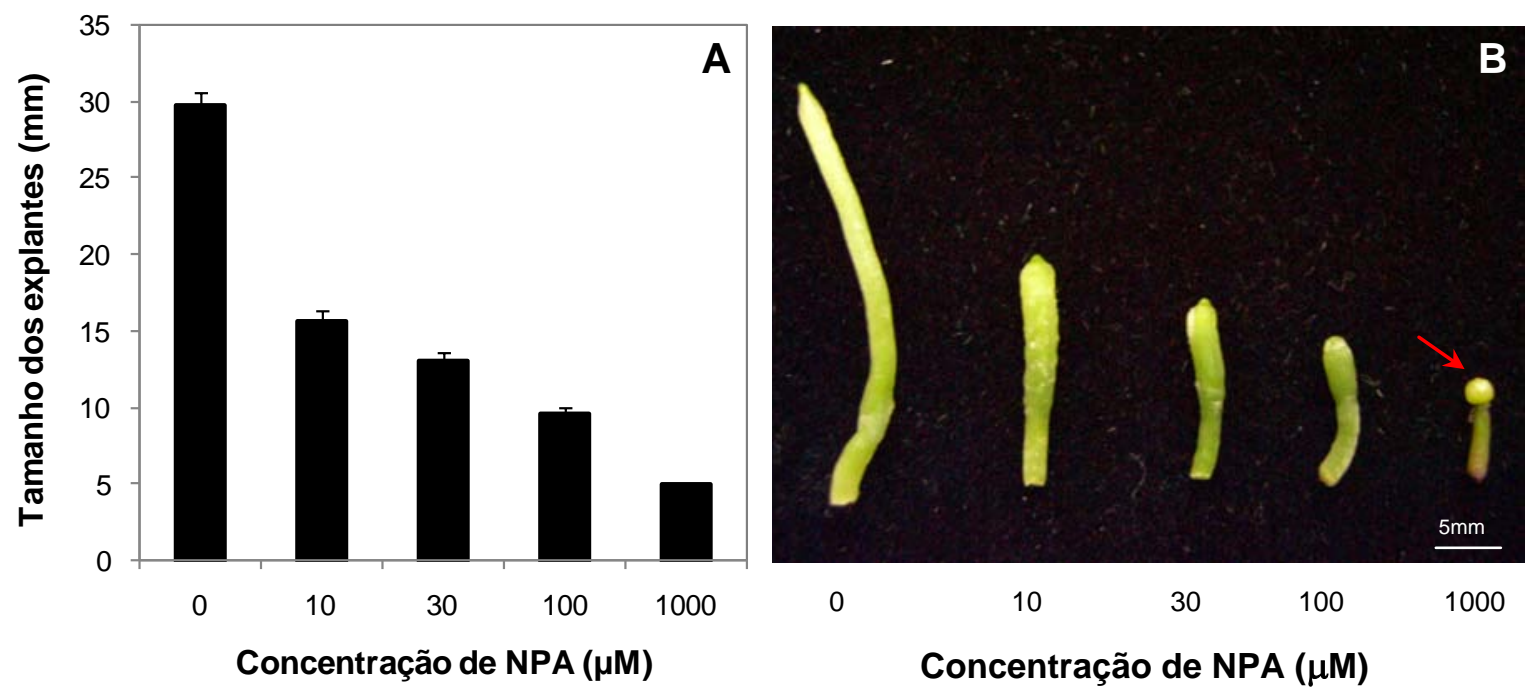

Figura 30: Respostas de ápices radiculares de C. fimbriatum (isolados de plantas com 30 dias de idade) após 20 dias de incubação na presença de 0; 10; 30; 100 ou 1000 $\mu$ M de NPA. (A) Tamanho dos explantes após os tratamentos. Barras de erro indicam o erro padrão; (B) fenótipo dos explantes após os tratamentos. Seta indica intumescimento do meristema apical radicular.

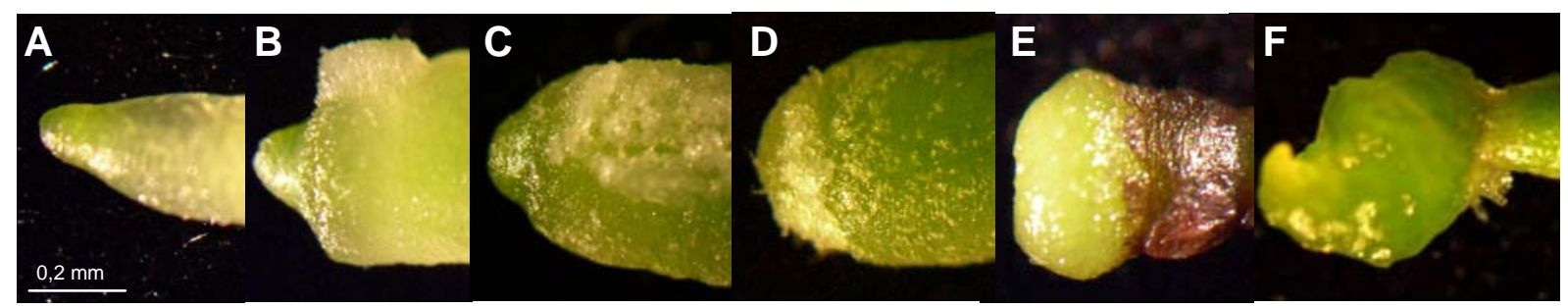

Figura 31: Sequiência de modificações fenotípicas ocorridas na região meristemática de raízes de C. fimbriatum (30 dias de idade) após 20 dias de incubação em diferentes

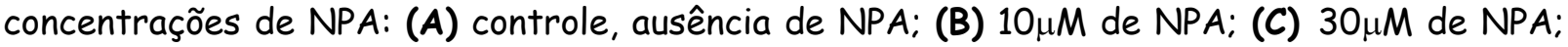
(D) $100 \mu \mathrm{M}$ de NPA; (E) $1000 \mu \mathrm{M}$ de NPA e (F) explantes tratados com $1000 \mu \mathrm{M}$ de NPA por 10 dias e transferidos para cultivo em meio básico por mais 10 dias. 
No entanto, nenhum dos explantes intumescidos desenvolveu gemas durante o período de exposição ao NPA; estas, todavia, foram observadas em cerca de $78 \%$ dos explantes tratados por 10 dias com $1000 \mu \mathrm{M}$ NPA seguido da transferência para o meio básico para incubação por mais 10 dias (Figuras 31F e Tabela 4). Vale ressaltar que as plantas originadas a partir dessas gemas caulinares apresentaram alterações na organização do eixo caulinar e na filotaxia.

Tabela 4: Respostas morfogênicas de ápices radiculares isolados de plantas de C. fimbriatum com 30 dias, os quais foram incubados por 20 dias na ausência (-NPA) ou presença contínua (+NPA) de $1000 \mu M$ de NPA, ou submetidos ao tratamento por 10 dias com $1000 \mu M$ de NPA e, em seguida, transferidos para cultivo em meio básico por mais 10 dias (+NPA / -NPA). Valores médios acompanhados dos respectivos erros padrão.

\begin{tabular}{ccc}
\hline Tratamentos & \% MAR intumescido & \% Conversão \\
\hline - NPA & 0 & 0 \\
\hline+ NPA & $100 \pm 0$ & 0 \\
\hline+ NPA / NPA & $100 \pm 0$ & $78 \pm 2,5$ \\
\hline
\end{tabular}

Em contrapartida, o tratamento de ápices radiculares jovens, isolados de plantas com 30 dias de idade, com diferentes concentrações de AIA revelou que essa auxina promovia o crescimento longitudinal destes explantes jovens após o isolamento da planta-mãe. É interessante observar que as concentrações de $5 \mu \mathrm{M}$ e $10 \mu \mathrm{M}$ de AIA foram as que se mostraram mais promotoras para o crescimento longitudinal dos ápices radiculares isolados (Figura 32). 

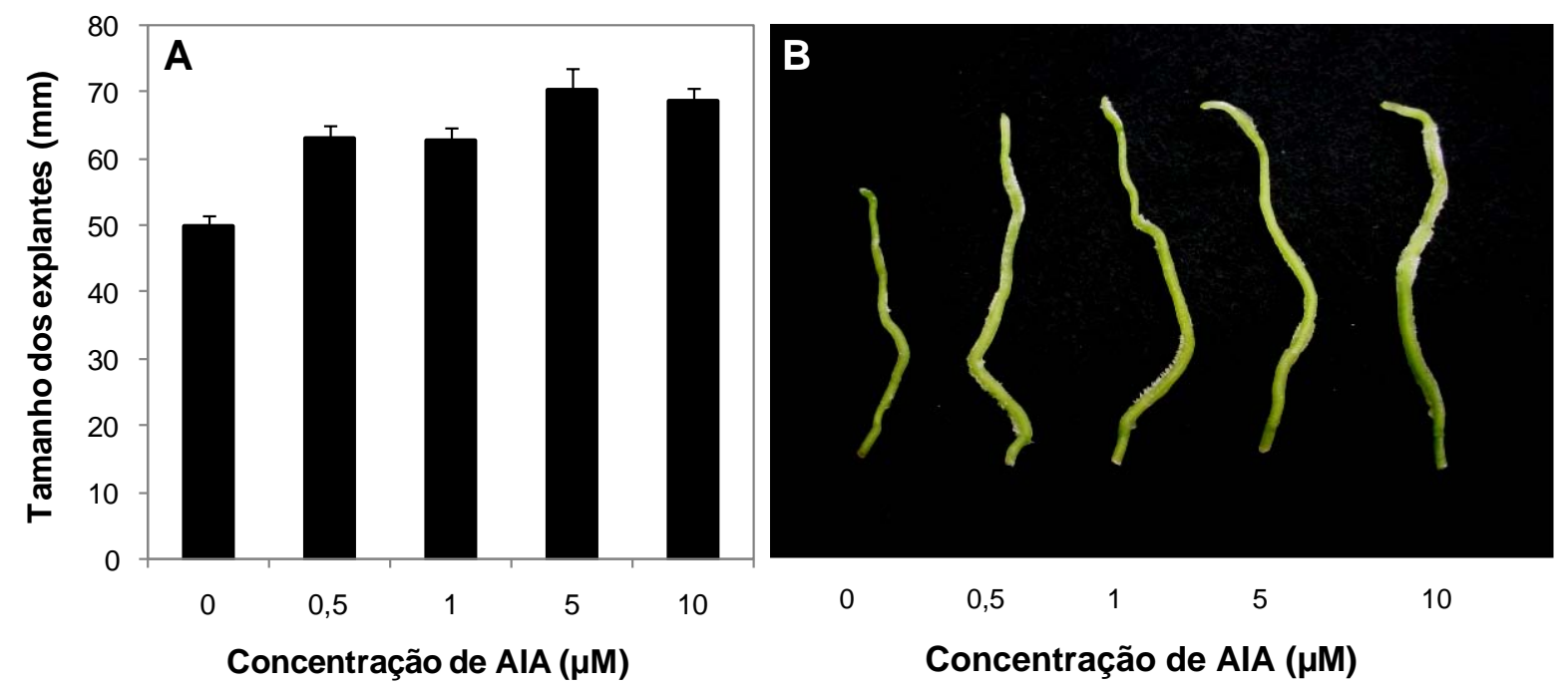

Figura 32: Crescimento longitudinal de ápices radiculares isolados de plantas com 30 dias de idade tratados com 0; 0,5; 1; 5 e 10 $\mu$ M de AIA: (A) Tamanho médio dos explantes após 60 dias de incubação de tratamento. As barras indicam o erro padrão; (B) Fenótipo dos explantes após 60 dias em incubação nos diferentes tratamentos.

Efeitos do AIA sobre o desenvolvimento de ápices radiculares competentes ligados à planta$\underline{\text { mãe }}$

A transferência de plantas intactas com 240 dias de idade para um meio de cultura novo, destituído de reguladores de crescimento (controle), foi suficiente para desencadear a retomada do crescimento de parte das raízes que já havia atingido o crescimento determinado sob as condições anteriores de cultura (Tabela 5 e Figura 33A).

Todavia, a suplementação do meio de cultura de transferência com AIA proporcionou a retomada de crescimento longitudinal em um número maior de raízes velhas $(13,28 \%$ das raízes). Todavia, nenhuma conversão radicular foi detectada sob essa condição (Tabela 5 e Figura 33A). É interessante ressaltar que a partir do ponto de retomada de crescimento, as raízes velhas, antes afiladas, adquiriram um aspecto mais vigoroso, parecido com as de raízes mais jovens (Figura 33B). A suplementação concomitante do meio com AIA e zeatina, por sua vez, induziu a retomada do crescimento em 9,43\% das raízes velhas, ao passo que proporcionou também a conversão de 5,98\% dos ápices radiculares ligados às plantas 
(Tabela 5). As respostas organogênicas de ápices radiculares isolados de plantas com 240 dias (competentes para conversão em gemas) também foram dependentes da presença ou ausência de auxina no meio de cultura. Observou-se que os explantes isolados de plantas com 240 dias de idade quando incubados na condição controle (ausência de auxina no meio) apresentaram, conforme exposto anteriormente na figura 4E, a conversão do MAR em gemas caulinares em grande proporção (Tabela 5 e Figura 33C).

No entanto, a inoculação de explantes de mesma procedência em meio de cultura suplementado com $1 \mu \mathrm{M}$ de AIA proporcionou a inibição total da conversão de seus MARs em gemas, ao passo que parte dos ápices radiculares mostrou-se competente para responder ao sinal da auxina e retomar o crescimento radicular longitudinal (Tabela 5 e Figura 33C). A outra parte dos explantes incubados na presença de AIA que não retomou o crescimento radicular também não apresentou qualquer outra resposta organogênica, sendo que cerca de $30 \%$ dos ápices radiculares isolados de raízes velhas e incubados na presença de AIA apresentaramse amarelados, dando indicações de morte do explante.

Tabela 5: Respostas organogênicas de ápices radiculares isolados ou ligados a plantas intactas de C. fimbriatum com 240 dias de idade: porcentagem de raízes com retomada do crescimento e porcentagem de ápices radiculares com conversão do MAR em gemas. Os dois tipos de materiais foram inoculados em novo meio de cultura suplementado ou não com $1 \mu M$ de AIA, onde permaneceram em incubação por 30 dias. Junto aos valores médios encontram-se os respectivos erros padrão.

\begin{tabular}{|c|c|c|}
\hline Tratamentos & \% Crescimento Radicular Retomado & \% Conversão \\
\hline Controle (plantas) & $5,10 \pm 0,19$ & 0 \\
\hline $1 \mu \mathrm{M}$ AIA (plantas) & $13,28 \pm 1,7$ & 0 \\
\hline $1 \mu \mathrm{M}$ AlA + 1 $\mu \mathrm{M}$ Zeatina (plantas) & $9,43 \pm 0,97$ & $5,98 \pm 0,86$ \\
\hline Controle (explantes) & 0 & $83,33 \pm 3,34$ \\
\hline $1 \mu \mathrm{M}$ AIA (explantes) & $23,33 \pm 3,34$ & 0 \\
\hline $1 \mu \mathrm{M} \mathrm{AIA}+1 \mu \mathrm{M}$ Zeatina (explantes) & 0 & $80,00 \pm 5,78$ \\
\hline
\end{tabular}




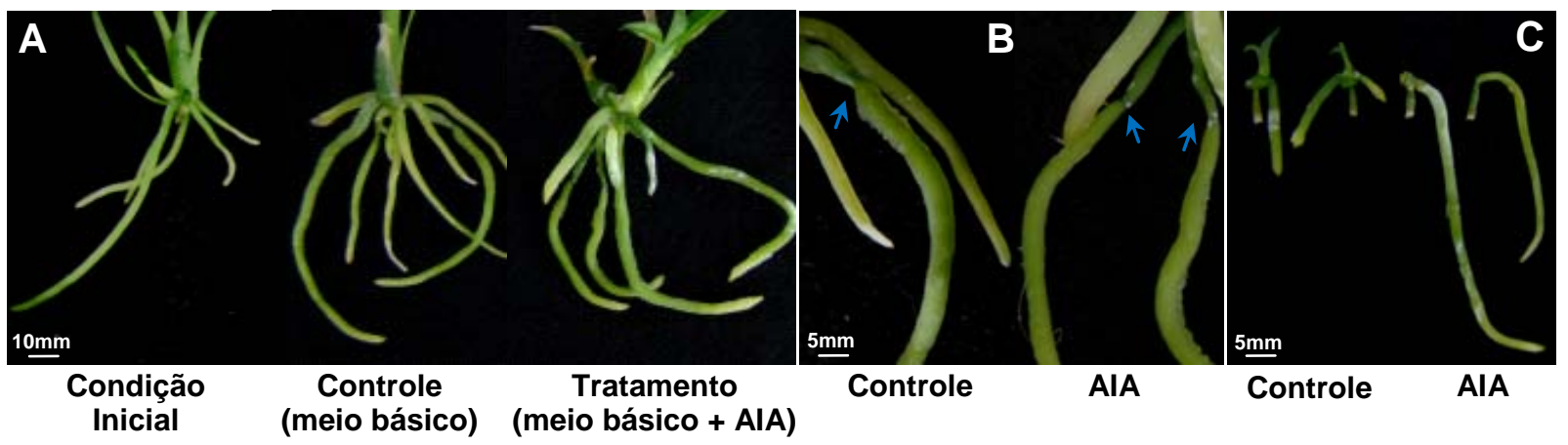

Figura 33: Respostas organogênicas de ápices radiculares isolados ou ligados a plantas intactas de C. fimbriatum com 240 dias de idade, os quais foram submetidos a 30 dias de incubação em novo meio de cultura suplementado ou não com $1 \mu M$ de AIA (ácido indolilacético): (A) Aspecto morfológico do sistema radicular de plantas com 240 dias de idade antes da transferência para o novo meio (condição inicial), bem como após o período de renovação das condições de cultura na ausência (controle) e na presença de AIA (tratamento); (B) Detalhe da região de retomada do crescimento radicular em raízes de plantas que foram transferidas para um novo meio de cultura na presença e na ausência de AIA (indicado por setas azuis) e (C) Aspecto morfológico de ápices radiculares isolados que apresentaram resposta organogênica após o período de incubação na ausência de AIA (controle com conversão do MAR em gemas) e na presença dessa auxina (retomada do crescimento radicular).

\section{IV.4. Papel do etileno na aquisição de competência}

\section{Emissão de etileno durante a aquisição de competência}

Os resultados obtidos com a quantificação dos teores de etileno ao longo do envelhecimento das plantas indicaram que as quantidades desse hormônio produzido por plantas com idade entre 30 e 120 dias não se apresentou significativamente distinta, no entanto, plantas com 240 dias de idade emitiram cerca de 5 vezes mais etileno do que aquelas com idades inferiores (Figura 34). 


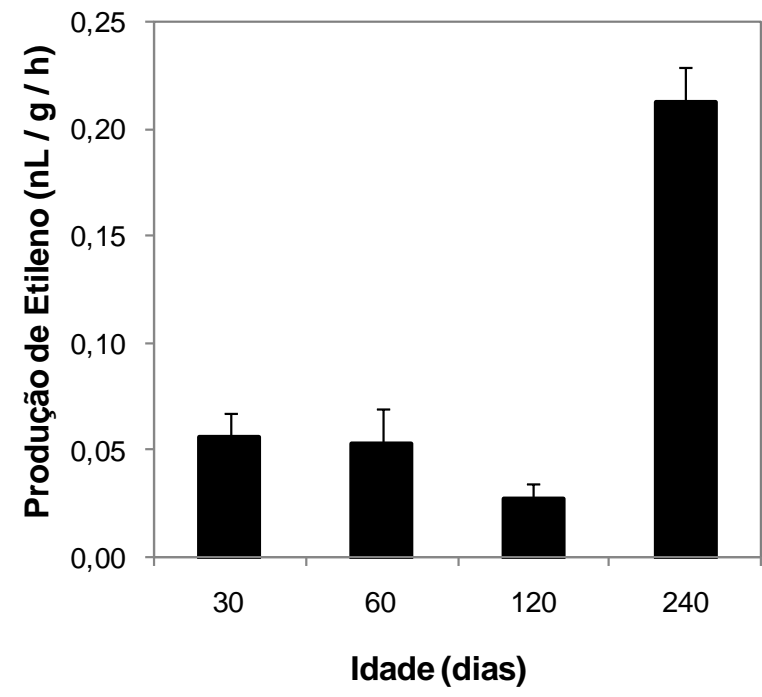

Figura 34: Teor de etileno emitido por plantas de C. fimbriatum com 30, 60, 120 e 240 dias de idade. As barras indicam o erro padrão.

\section{Efeitos de tratamentos com etileno sobre o crescimento radicular de plantas intactas}

Tratamentos de plantas jovens, a partir de 30 dias de idade, com concentrações elevadas de etileno ocasionaram alterações proeminentes no desenvolvimento do sistema radicular e caulinar de plantas de C. fimbriatum sob condições in vitro.

Verificou-se que as três concentrações de etileno adicionadas aos frascos de cultura (50, 500 e 5000 $\mu \mathrm{M})$ proporcionaram efeito semelhante na dinâmica de crescimento das raízes analisadas, sendo que todas as concentrações testadas resultaram numa redução da taxa de crescimento radicular em cerca de $50 \%$ após a $2^{\mathrm{a}}$ semana de tratamento. Sob tais condições, o crescimento da primeira raiz de cada planta cessou por volta do final da $5^{a}$ semana de tratamento (plantas com cerca de 65 dias de idade). As raízes controle, por sua vez, apresentaram parada do crescimento quando completaram cerca de 86 dias de idade (Figura 35). A aplicação de 1-metilciclopropeno (1-MCP), uma substância inibidora de receptores de etileno, promoveu o crescimento das primeiras raízes de cada planta durante as duas primeiras semanas de tratamento, permitindo um aumento de cerca de $33 \%$ na taxa de crescimento radicular em relação ao controle (Figura 36). No entanto, entre a $3^{\mathrm{a}}$ e $4^{\mathrm{a}}$ semanas de tratamento essa substância não possuiu efeito significativo em relação ao controle, sendo 
que após a $4^{\mathrm{a}}$ semana verificou-se uma tendência à inibição sobre a taxa de crescimento radicular em todas as concentrações empregadas de 1-MCP (Figura 36).

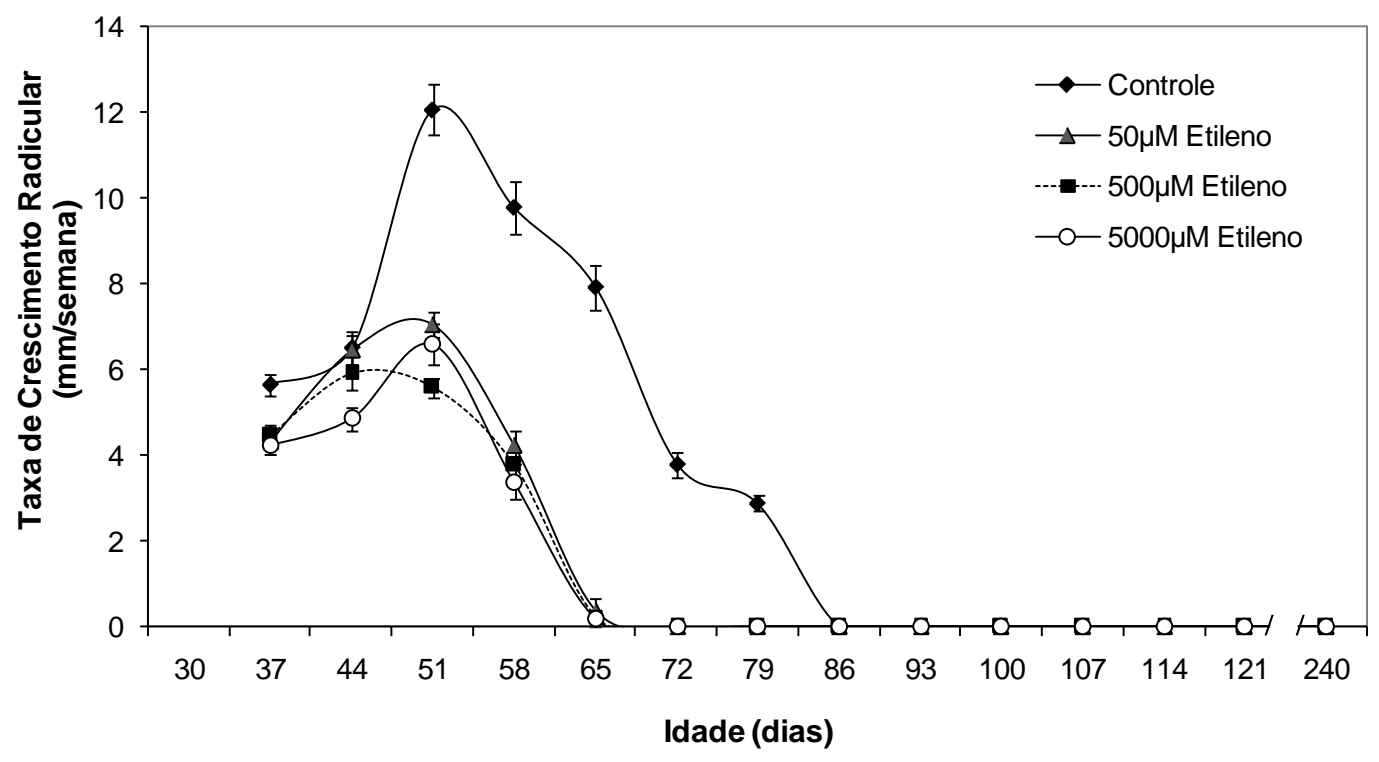

Figura 35: Taxa de crescimento semanal ( $\mathrm{mm} / \mathrm{semana}$ ) da primeira raiz de plantas de $C$. fimbriatum a partir de 30 dias de idade, submetidas a tratamentos semanais com 0;50; 500 ou $5000 \mu \mathrm{M}$ de etileno durante 5 semanas. As barras de erro indicam o erro padrão.

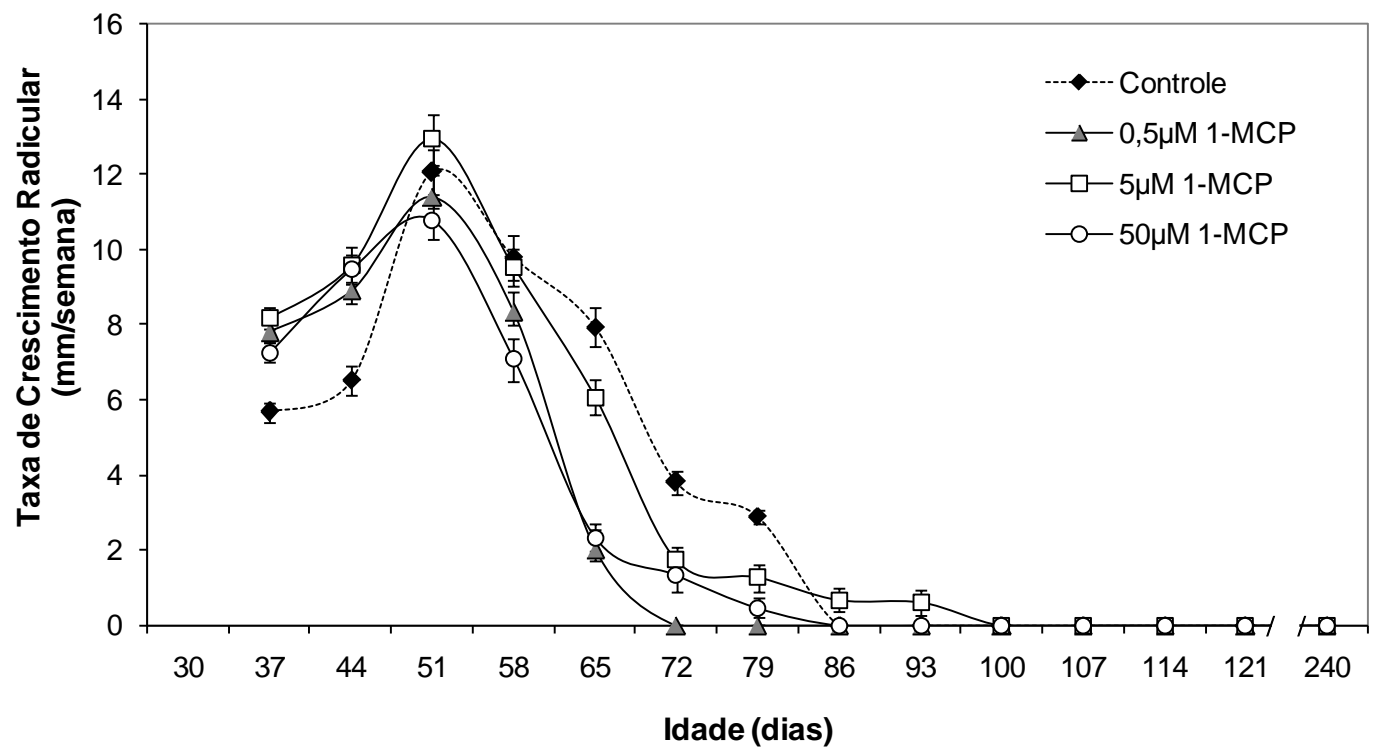

Figura 36: Taxa de crescimento semanal ( $\mathrm{mm} / \mathrm{semana}$ ) da primeira raiz de plantas de $C$.

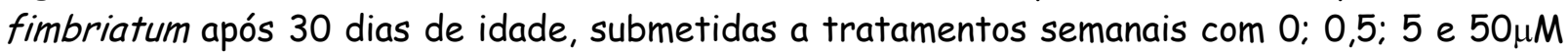
de 1-MCP durante 5 semanas. As barras de erro indicam o erro padrão. 
O tratamento das plantas com 1-MCP apesar de ter provocado variações na velocidade de crescimento radicular ao longo do período experimental, não se refletiu de forma proporcionalmente significativa no tamanho final da primeira raiz das plantas analisadas (Figura 37). Em contrapartida, estas raízes tratadas com concentrações elevadas de etileno apresentaram uma redução notável de tamanho, como conseqüência da menor velocidade de crescimento durante todo o período experimental (Figura 37).

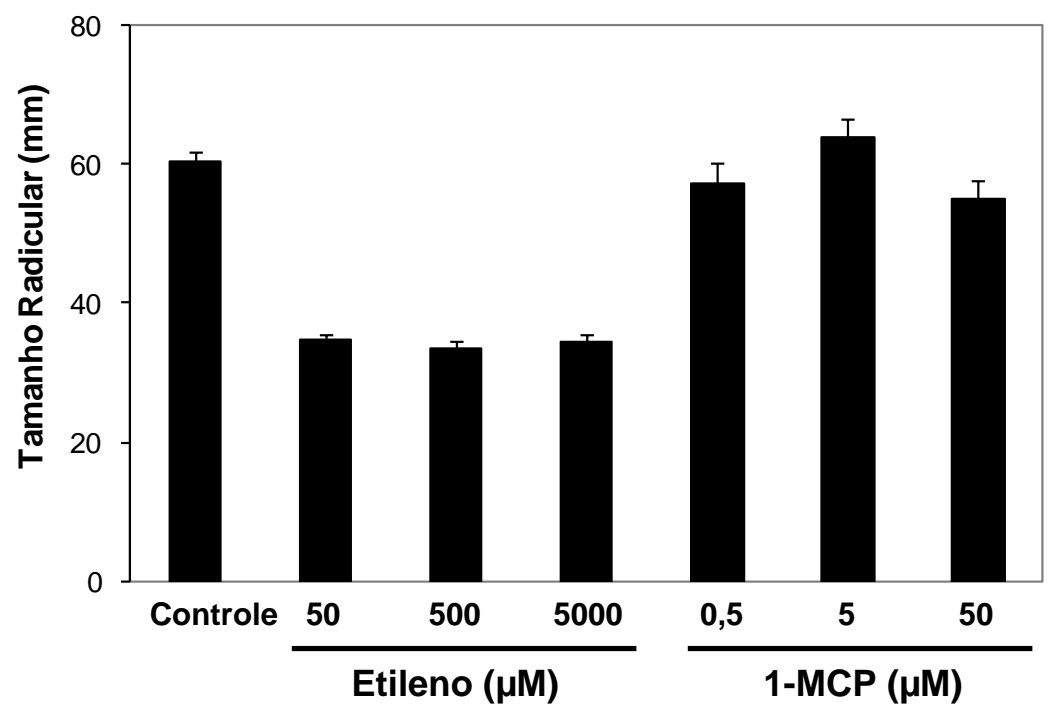

Figura 37: Tamanho final das primeiras raízes formadas em plantas de C. frimbriatum

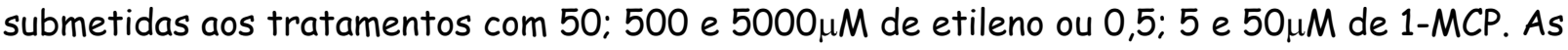
barras de erro indicam o erro padrão.

\section{Efeitos do etileno sobre as modificações estruturais do MAR}

As análises histológicas obtidas com ápices radiculares recém-isolados de plantas jovens de $C$. fimbriatum tratadas com $500 \mu \mathrm{M}$ de etileno por 10 e 20 dias indicaram que esse hormônio além de inibir o crescimento radicular, também ocasionou alterações histológicas nos ápices radiculares, as quais se agravaram com a duração do tratamento (Figura 38).

Esses resultados mostraram que após 10 dias do início do tratamento de plantas jovens com etileno já era possível se visualisar várias mudanças teciduais no ápice da 
primeira raiz formada em cada planta. Quando tais ápices foram comparados ao material controle (Figuras 38A e 38B) observaram-se indícios de diferenciação dos tecidos dentro do ápice radicular tais como no córtex, cilindro vascular e epiderme, bem como alterações iniciais na organização de parte das células dentro do MAR (Figura 38B).

Apesar dos ápices radiculares tratados com etileno por 10 dias ainda mantiveram, assim como o controle, a organização celular do tipo fechada, pôde-se verificar a existência de células do córtex e cilindro vascular em estágio avançado de diferenciação em uma região vizinha ao CQ (Figuras 38B e 38D). Essa tendência foi acentuada após 20 dias do início do tratamento, quando se verificou uma profunda mudança estrutural no ápice radicular e na organização do MAR. Nesse caso, observou-se uma severa diferenciação de grande parte das células do ápice radicular, incluindo as pertencentes ao meristema fundamental, as quais se diferenciaram, em grande proporção, em células parenquimáticas (Figura 38E). Esse processo culminou no intumescimento da região apical das raízes, com a aparente perda da quiescência do CQ, cuja região foi ocupada por um conjunto numeroso de células ainda com características meristemáticas (Figura 38E). O tratamento com etileno durante 20 dias resultou num aparente ganho de competência por parte do MAR para conversão em gemas caulinares, devido a formação de um meristema caulinar com seus primórdios foliares no ápice radicular alterado, com células envolvidas apresentando elevada atividade mitótica (Figuras 30F e 38G). 


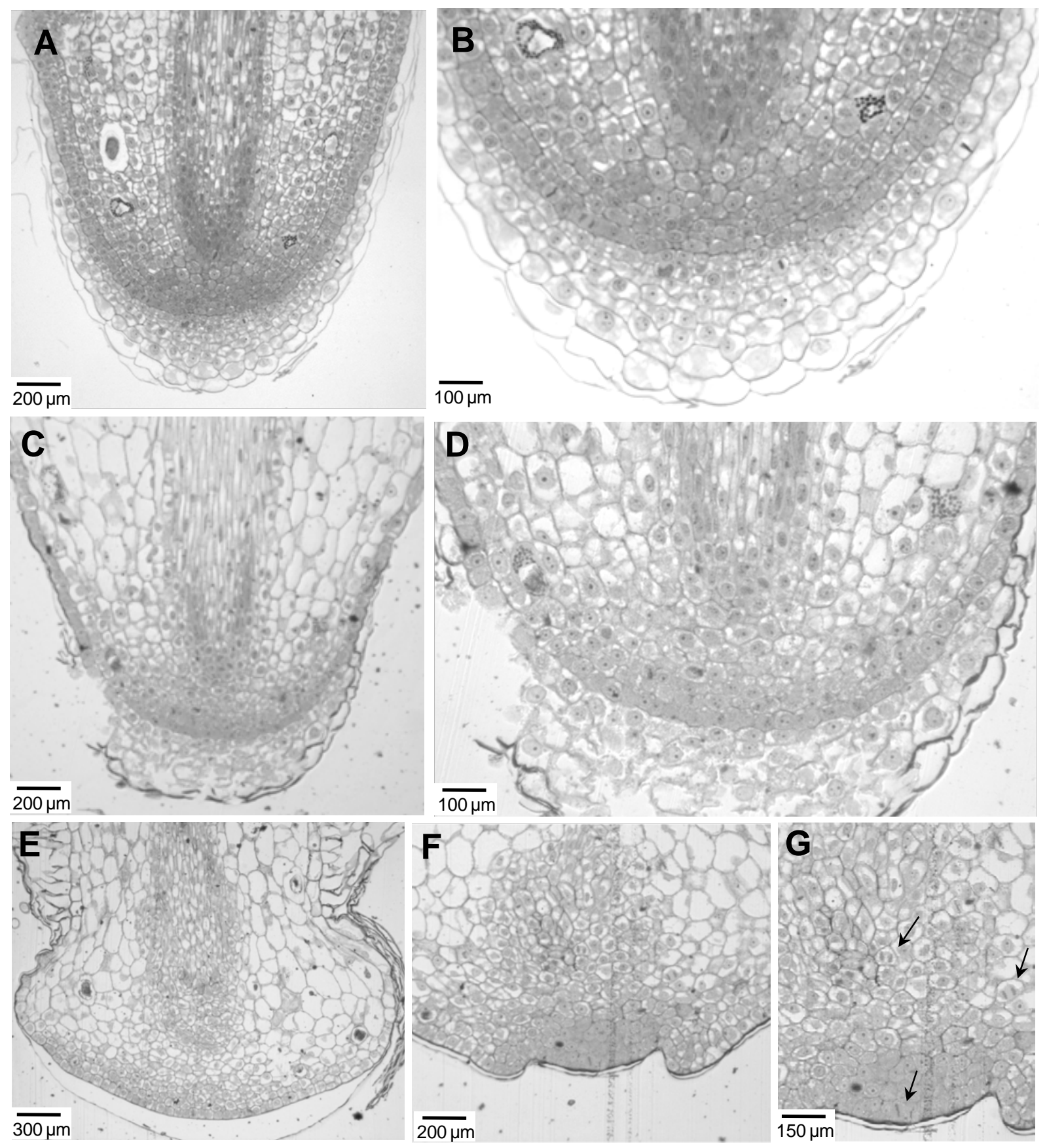

Figura 38: Modificações estruturais em ápices radiculares recém-isolados de plantas de $C$. fimbriatum com 40 ou 50 dias de idade, e tratadas durante 10 ou 20 dias com $500 \mu M$ de etileno: $(A)$ e (B) Controle; $(C)$ e (D) tratamento por 10 dias; $(E),(F)$ e $(G)$ tratamento por 20 dias. Sendo que: (A), (C) e (E) visão geral do ápice radicular; (B), (D) e (F) detalhe do MAR; $(G)$ detalhe do meristema caulinar recém-estabelecido no MAR intumescido. Setas indicam figuras mitóticas. 
Efeitos do etileno sobre a aquisição de competência para conversão do MAR em gemas $\underline{\text { caulinares }}$

A adição de concentrações relativamente elevadas de etileno ao interior dos frascos de plantas em início do desenvolvimento, além de ocasionar a inibição do crescimento radicular e alterações na organização do MAR, também propiciou o ganho de competência para conversão do MAR em gemas caulinares.

Essa constatação decorre do fato de que se verificou a olho nu a partir da $4^{\mathrm{a}}$ semana de tratamento o intumescimento dos ápices radiculares, o qual desencadeou a formação de gemas caulinares nas plantas intactas (Figura 39). As três concentrações de etileno testadas desencadearam a conversão no MAR da raiz mais velha de todas as plantas após cerca de 85 dias de incubação; em contrapartida, as plantas controle não tiveram seus ápices radiculares convertidos em gemas (Figura 39).

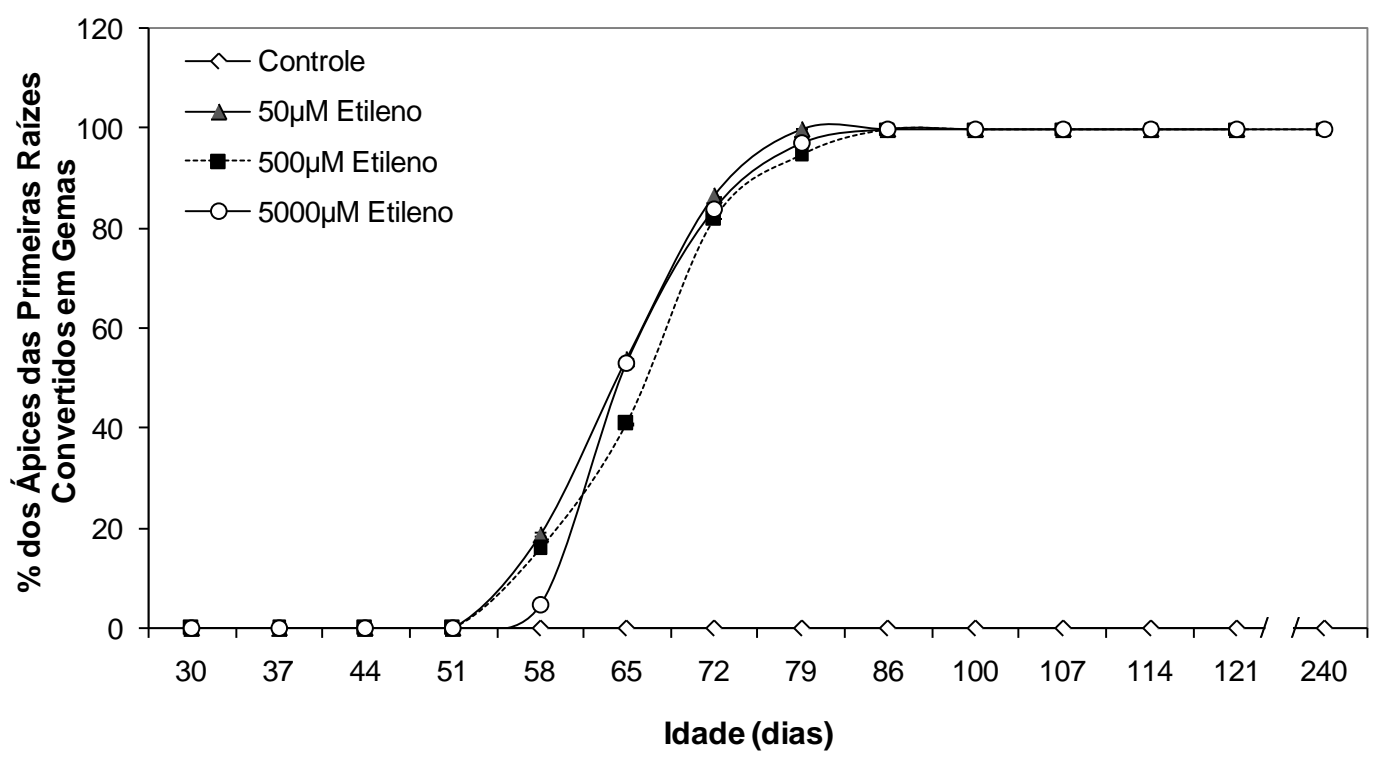

Figura 39: Frequiência de conversões de ápices radiculares ligados às plantas que foram tratadas durante 5 semanas consecutivas com 0; $50 \mu \mathrm{M} ; 500 \mu \mathrm{M}$ ou $5000 \mu \mathrm{M}$ de etileno, a partir de 30 dias de idade (considerada a primeira raiz de cada planta). 
Efeitos do etileno sobre o desenvolvimento do sistema radicular de C. fimbriatum

Verificou-se que a aplicação de etileno, além de estimular a conversão do MAR da primeira raiz em gema caulinar, também induziu esse processo organogênico em algumas raízes mais novas em cada planta analisada. As três concentrações de etileno testadas induziram a conversão do MAR em gema em cerca de 30\% do conjunto total de raízes de cada planta (Figura 42C), ao passo que nenhuma das raízes do grupo controle, ou qualquer tratamento com 1-MCP, apresentaram conversão (Figura 40A).

O tratamento com etileno também provocou um aumento no número de raízes formadas nas plantas, sendo que o número médio destas por planta tratada chegou a dobrar em relação ao controle (Figura 40B). A presença das duas menores concentrações de 1-MCP utilizadas $(0,5$ e $5 \mu \mathrm{M})$, por sua vez, desencadeou efeito contrário, causando a inibição da formação de novas raízes adventícias em cerca de 30\% em relação ao controle (Figura 40B). O aumento do número de raízes em plantas tratadas com etileno acarretou um aumento conspícuo na massa fresca (MF) do sistema radicular das plantas, sendo que os indivíduos tratados com 1-MCP não apresentaram alterações significativas nesse parâmetro quando comparados ao controle (Figura 40C).

Concentrações de etileno relativamente elevadas possibilitaram também a diferenciação de células especializadas nas raízes, tais como pêlos absorventes em toda a extensão radicular e de células com espessamento parietal secundário no córtex maduro (Figuras 41D-41F). Em raízes de plantas mantidas na condição controle e nos tratamentos com 1-MCP não foi observado o espessamento das paredes celulares do córtex, nem a formação de pêlos absorventes na periferia das raízes, mas sim, a diferenciação de velame (Figuras 41A-41C e 41G-41I). O velame esteve presente em um número reduzido de camadas nos tratamentos com 1-MCP em relação ao observado nas raízes controle (Figuras $41 \mathrm{H}$ e $41 \mathrm{~B}$, respectivamente). 


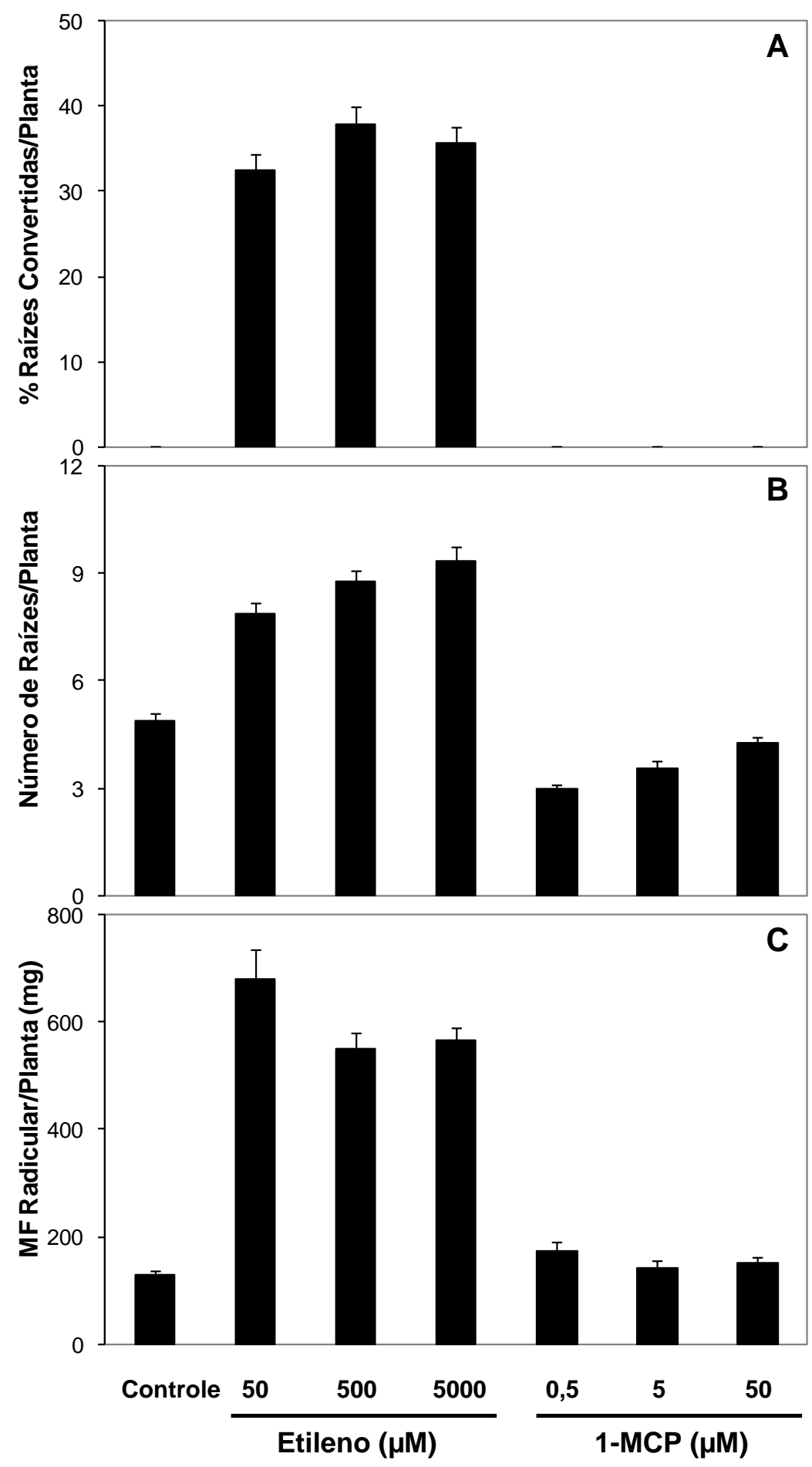

Figura 40: Dados morfométricos de raízes de plantas de C. fimbriatum com 120 dias de idade tratadas durante cinco semanas com 0; 50; 500 ou $5000 \mu \mathrm{M}$ de etileno ou com 0; 0,5; 5 e $50 \mu M$ de 1-MCP. (A) \% de raízes de cada planta convertidas em gemas caulinares; (B) $n^{\circ}$ médio de raízes formadas em cada planta; $(C)$ massa fresca média do sistema radicular em cada planta. As barras de erro indicam o erro padrão. 

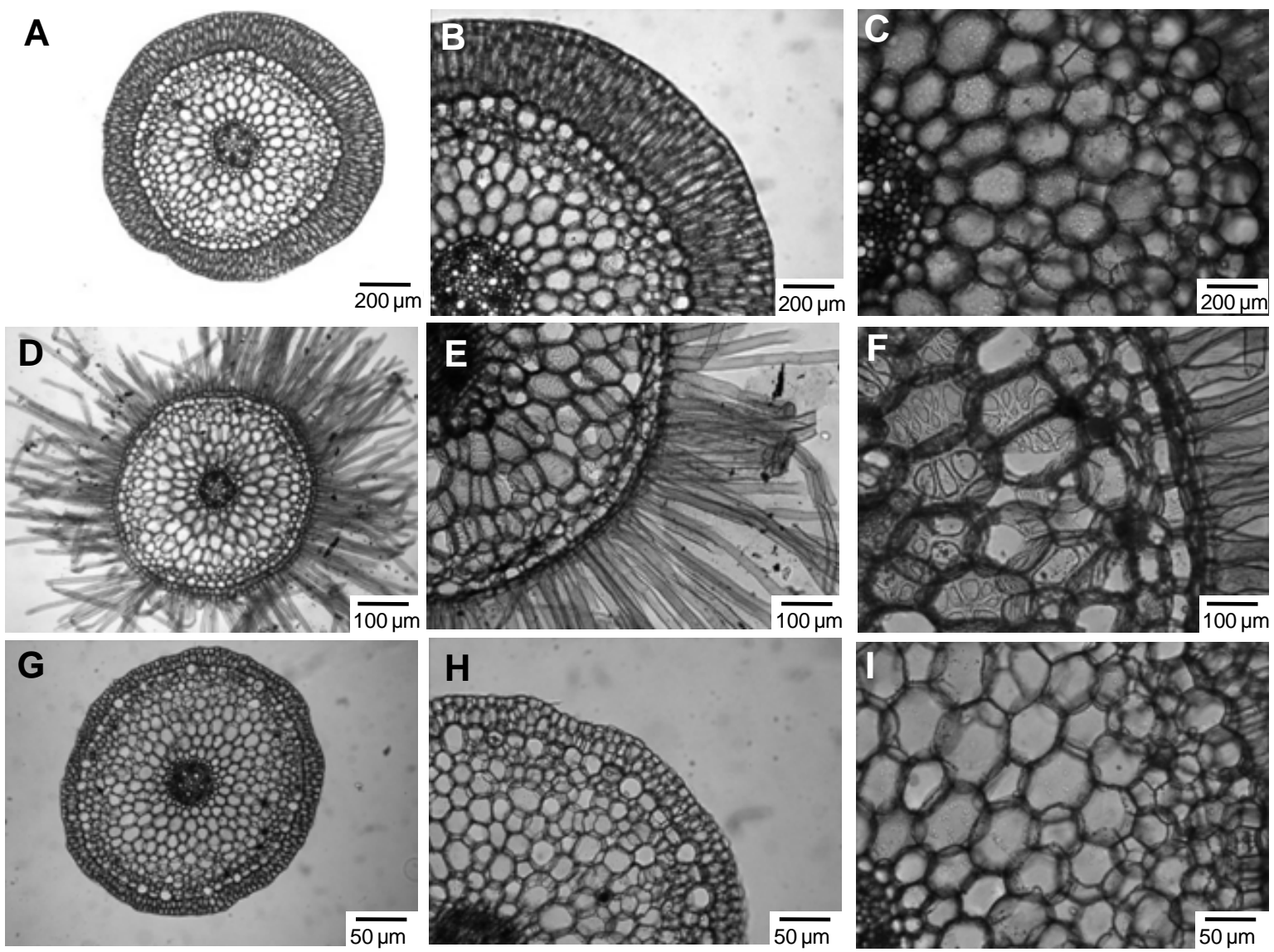

Figura 41: Modificações estruturais observadas em raízes de plantas de C. fimbriatum com 120 dias de idade após tratamentos com etileno e 1-MCP. (A - C) controle; (D - F) $500 \mu M$ de etileno; $(G-I) 5 \mu M$ de 1-MCP. (A, D e G) visão geral de corte transversão da parte madura da raiz; $(B, E$ e $H)$ detalhe do tecido de revestimento da raiz e $(C, F$ e $I)$ detalhe das células no córtex radicular. 
Modo geral, a aplicação etileno refletiu de maneira negativa no desenvolvimento da parte aérea das plantas de C. fimbriatum, conforme está ilustrado na figura 42. Dentre os parâmetros afetados, destacam-se o comprimento caulinar, massas fresca e seca do caule e a área foliar (dados não apresentados), sendo que ainda sob tais condições observou-se um efeito promotor na formação de novos brotos e folhas (dados não apresentados), no entanto, essas estruturas não apresentaram desenvolvimento normal (Figura 42A e 42D).

A aplicação das três concentrações testadas de 1-MCP, por sua vez, provocou o efeito oposto sobre a parte aérea de $C$. fimbriatum cultivado in vitro. Sob condições de menor percepção de etileno observou-se um aumento notável no número de folhas, área foliar e nas massas fresca e seca da parte aérea das plantas (dados não apresentados - Figura 42B).
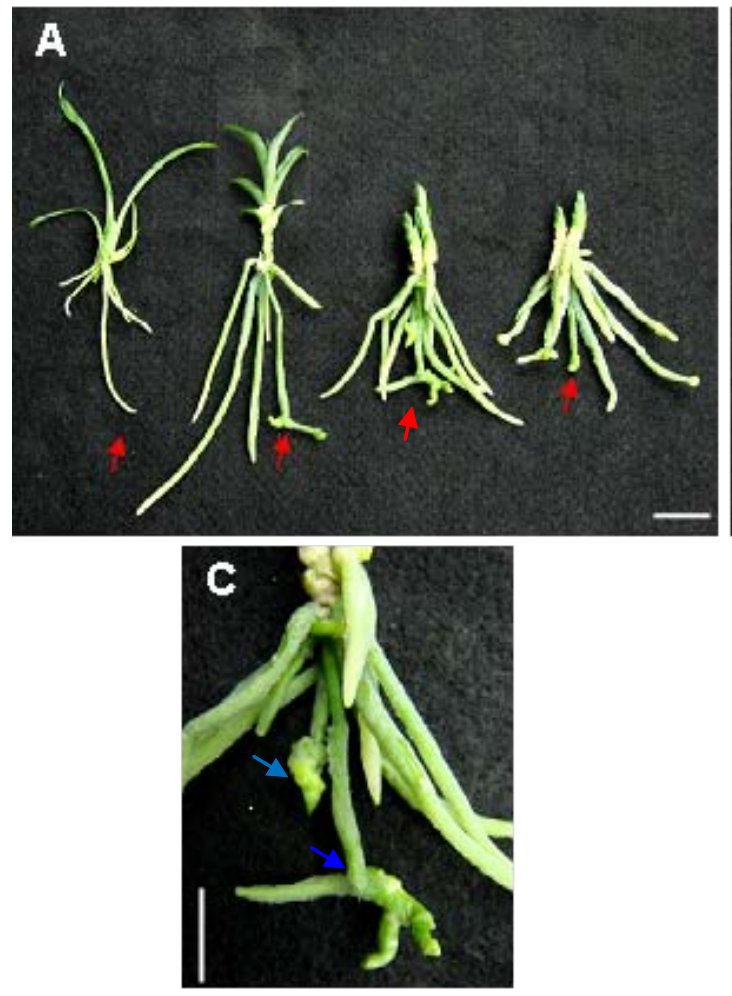
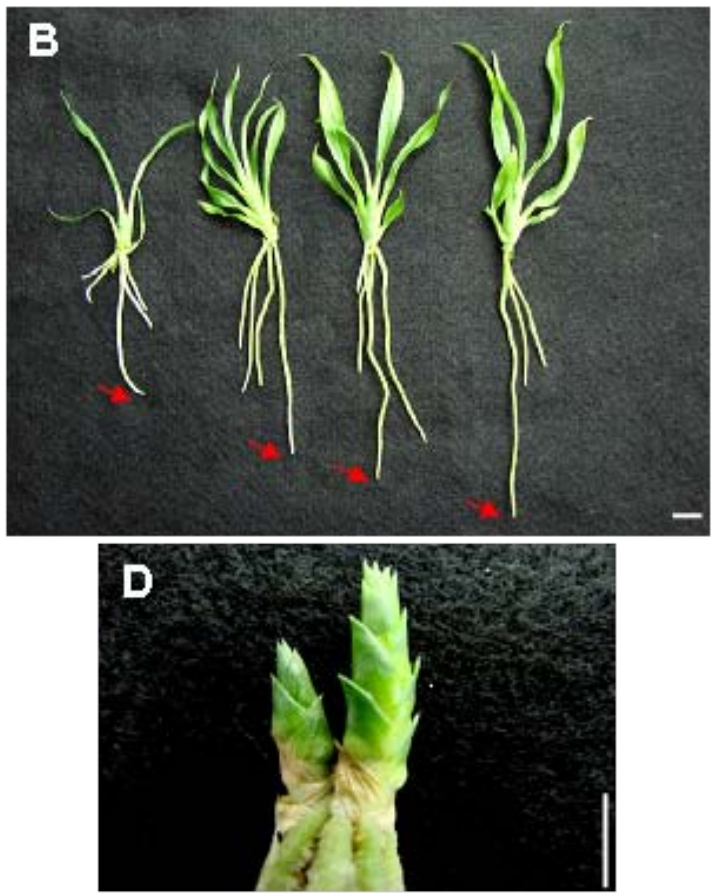

Figura 42: Fenótipo de plantas de C. fimbriatum com 120 dias de idade após tratamento com

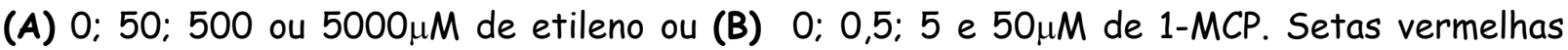
indicam a primeira raiz de cada planta. (C) Detalhe do sistema radicular de planta tratada com $500 \mu M$ de etileno - setas azuis indicam MARs convertidos em gemas caulinares; (D) detalhe das folhas escamiformes após tratamento com 500 $\mu \mathrm{M}$ de etileno. Escala: $100 \mathrm{~mm}$. 
Efeitos do etileno sobre o conteúdo de citocininas endógenas de ápices radiculares jovens

A análise dos conteúdos de Z, ZR, iP e iPR em ápices radiculares recém-isolados de plantas jovens de $C$. fimbriatum submetidas previamente ao tratamento com $500 \mu \mathrm{M}$ de etileno por 10 dias indicaram um aumento de cerca de três vezes no teor total das citocininas analisadas ( $Z+Z R+i P+i P R)$ em relação ao observado no material controle (Figura 43A). Tanto as citocininas do tipo $Z(Z+Z R)$ quanto as do tipo iP (iP+iPR) tiveram seus teores elevados; no entanto, ocorreu uma tendência à inversão do tipo de citocinina predominante no controle (tipo iP) em relação material tratado com etileno, o qual apresentou uma ligeira predominância de citocininas do tipo Z (Figura 43B).
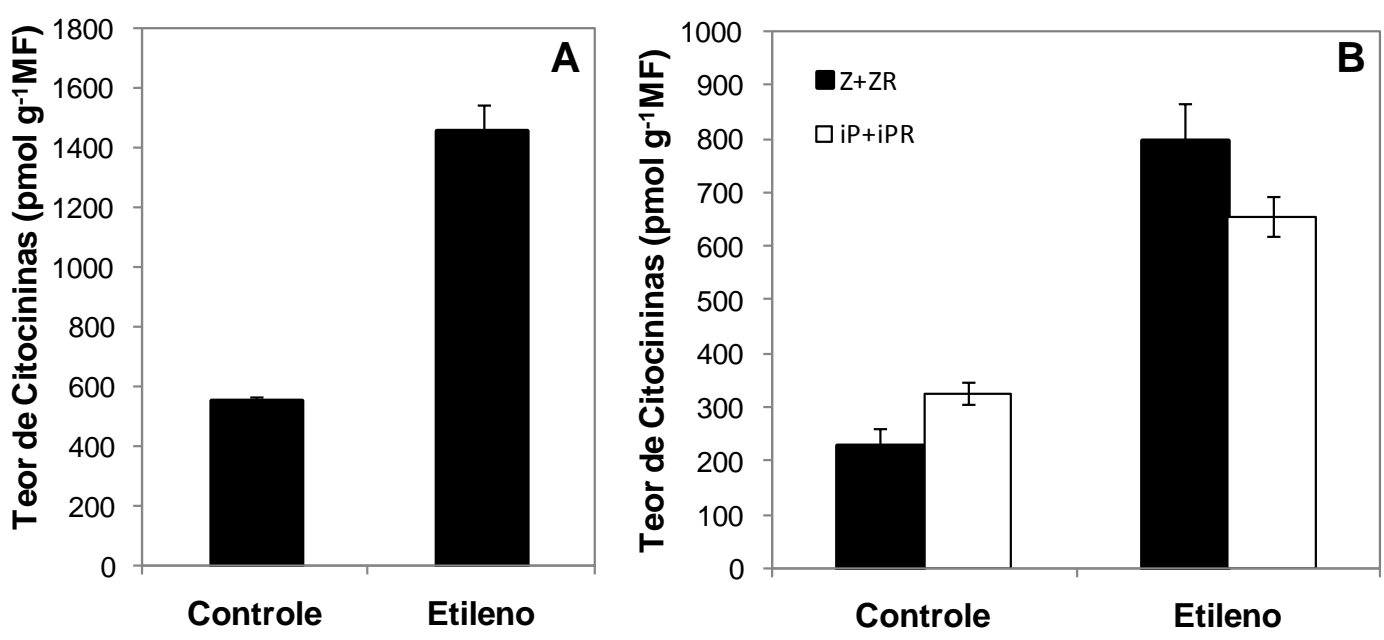

Figura 43: Teores endógenos de citocininas em ápices radiculares isolados de plantas jovens de C. fimbriatum previamente tratadas com $500 \mu M$ de etileno por 10 dias. $(A)$ conteúdo de citocininas totais $(Z+Z R+i P+i P R)$; $(B)$ conteúdo de citocininas do tipo iP (iP+iPR) e do tipo $Z$ $(Z+Z R)$. Barras de erro indicam erro padrão.

O tratamento de plantas jovens com etileno além de causar um aumento nos teores endógenos de citocininas, também ocasionou uma mudança no padrão de isômeros de ZR predominante nos ápices radiculares de C. fimbriatum. Verificou-se que o etileno provocou um aumento marcante nos teores de $t$-ZR, fazendo com que esse tipo de zeatina ribosídeo 
passasse a predominar nos ápices radiculares, ao passo que na condição controle o tipo predominante de ZR foi o isômero c-ZR (Figura 44).

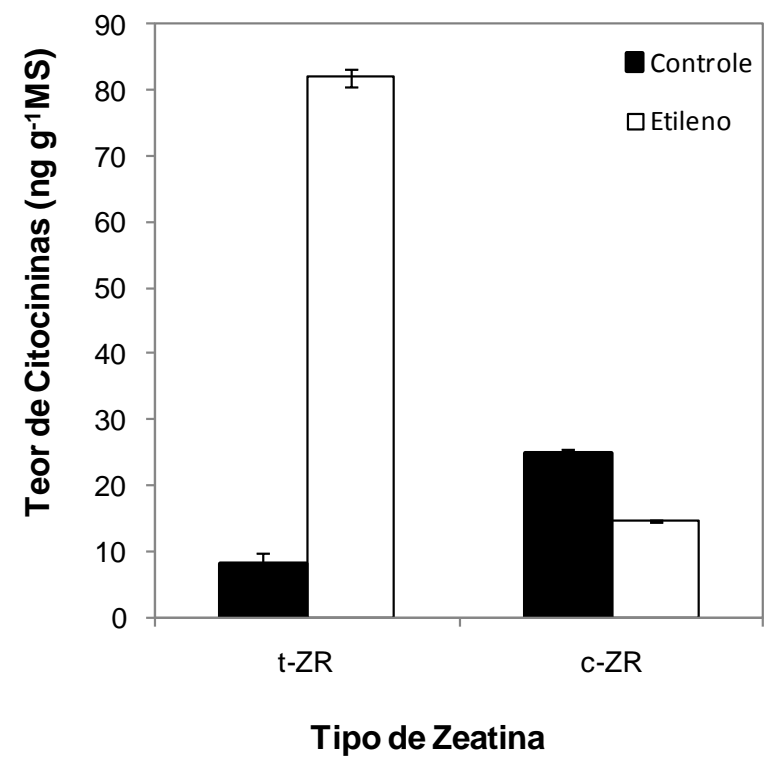

Figura 44: Teores dos isômeros ópticos cis e trans de zeatina ribosídeo (ZR) em ápices radiculares isolados de plantas jovens de C. fimbriatum previamente tratadas com $500 \mu M$ de etileno por 10 dias. Barras de erro indicam erro padrão.

\section{IV.5. Teores de giberelinas e ácido abscísico durante a aquisição de competência}

A análise dos teores endógenos de ácido abscísico (ABA) em ápices radiculares recém-isolados de plantas ao longo do envelhecimento revelou que a concentração desse hormônio tendia a aumentar durante esse processo, alcançado valores máximos nos ápices radiculares isolados de plantas com 240 dias de idade (Figura 45A).

Por outro lado, a concentração geral das giberelinas analisadas $\left(\mathrm{GA}_{1}+\mathrm{GA}\right)$ também aumentou de maneira notável nos ápices radiculares recém-isolados de plantas com 240 dias, sendo que se observou uma inversão nítida no tipo predominante dessas giberelinas em 
explantes competentes e não-competentes; enquanto $\mathrm{GA}_{1}$ se mostrou fortemente presente nos explantes com 240 dias de idade, $\mathrm{GA}_{7}$ predominou nos ápices mais jovens (Figura 45B).
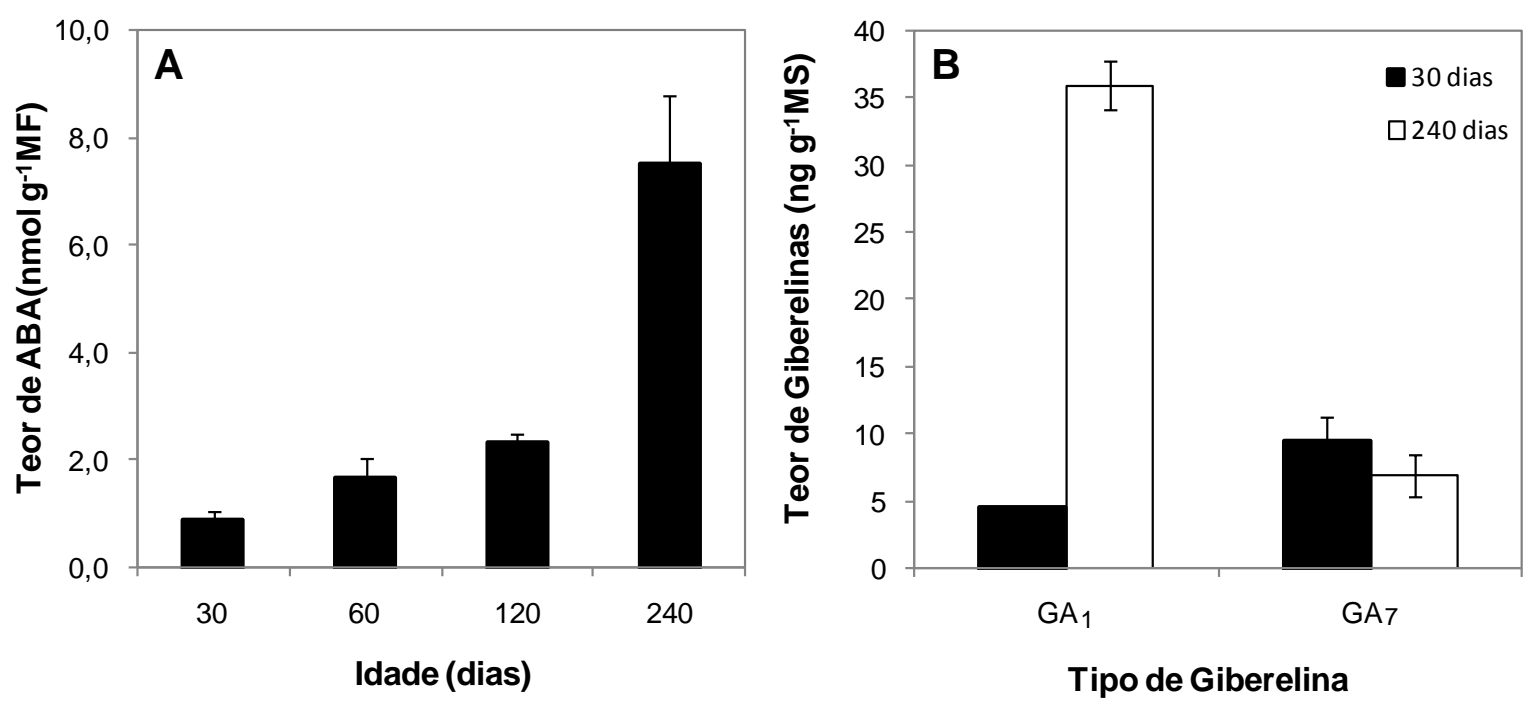

Figura 45: (A) Teores endógenos de ácido abscísico $(A B A)$ em ápices radiculares recémisolados de plantas de C. fimbriatum com 30, 60, 120 e 240 dias de idade; (B) Teores endógenos de giberelinas do tipo $G A_{1}$ e $G A 7$ em ápices radiculares recém-isolados de plantas de $C$. fimbriatum com 30 e 240 dias de idade. Barras de erro indicam erro padrão.

\section{IV.6. Envolvimento do estado redox na aquisição de competência}

$\underline{\text { Teores de ascorbato e glutationa durante a aquisição de competência }}$

As determinações dos teores de ascorbato (ASC) e glutationa (GSH) em ápices radiculares isolados de plantas ao longo do envelhecimento indicaram que ambos compostos diminuíram significativamente quando as plantas apresentaram 60 dias de idade, no entanto, não foram observadas variações proeminentes nos seus teores em ápices isolados de raízes mais velhas (Figura 46). Comparativamente, os teores de ASC decaíram com o envelhecimento radicular em maior intensidade que o observado para GSH (Figuras 46A e 46B, respectivamente). 

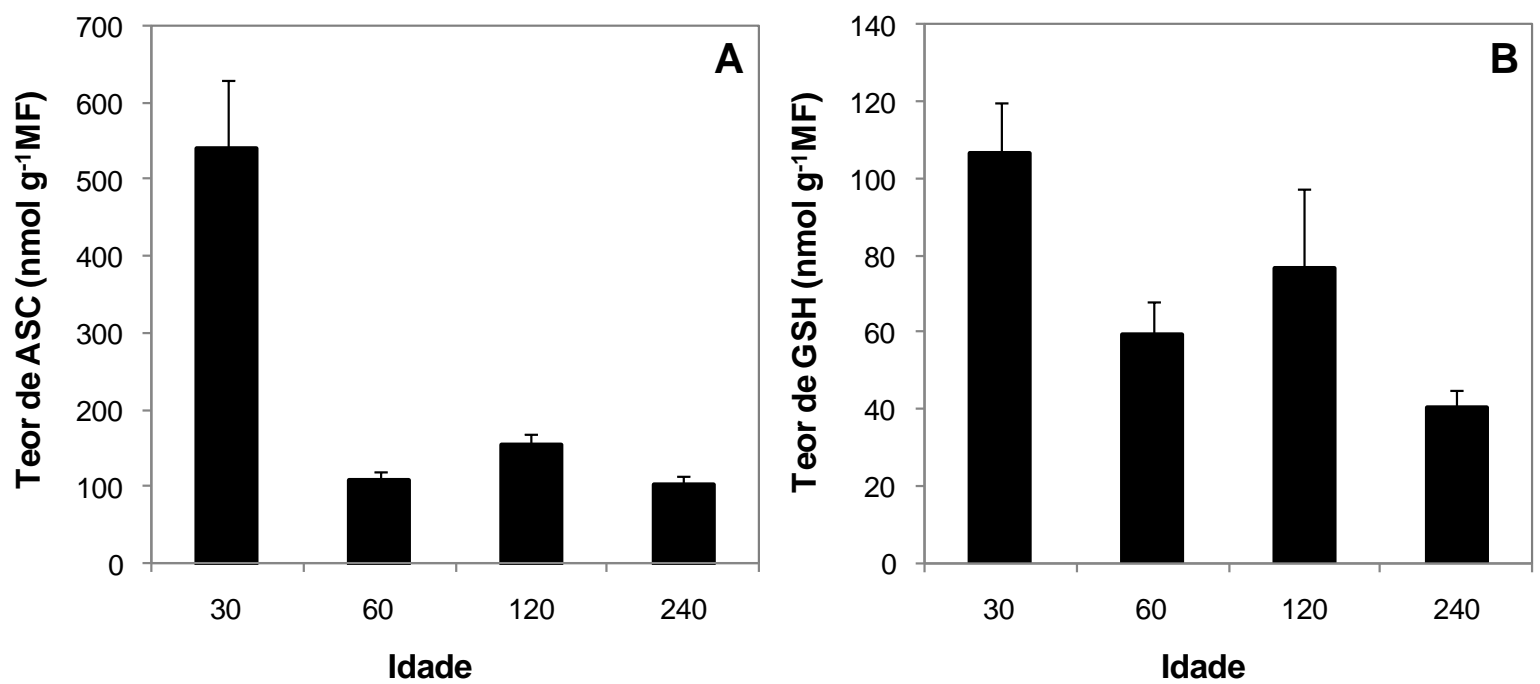

Figura 46: (A) Teores de ascorbato (ASC) em ápices radiculares recém-isolados de plantas de C. fimbriatum com 30, 60, 120 e 240 dias de idade; (B) Teores endógenos de glutationa $(G S H)$ em ápices radiculares recém-isolados de plantas de $C$. fimbriatum com as diferentes idades em questão. Barras de erro indicam erro padrão.

Efeitos de substâncias indutoras ou inibidoras do estresse oxidativo no desenvolvimento e aquisição de competência de ápices radiculares

O tratamento de ápices radiculares isolados de plantas com 30 dias de idades (nãocompetentes) com $1 \mu \mathrm{M}$ de paraquat, uma substância promotora de estresse oxidativo, provocou a inibição do crescimento longitudinal dos explantes radiculares em cerca de $70 \%$ em relação ao observado no controle. A aplicação de $0,1 \mu \mathrm{M}$ de paraquat, por sua vez, não se mostrou efetiva na inibição do crescimento longitudinal dos explantes, uma vez que não foram observadas diferenças significativas entre esse tratamento e a condição controle (Figura 47A e 47D).

No entanto, a incubação dos explantes durante todo o período experimental na presença da concentração mais elevada de paraquat inibiu conspicuamente o crescimento longitudinal dos explantes, porém não provocou a conversão dos explantes em gemas caulinares (Figura 47D). Todavia, quando se transferiram os explantes incubados por 30 dias 
nesse tratamento para um novo meio destituído de paraquat, verificou-se após 30 dias de incubação que $100 \%$ dos explantes se converteram em gemas caulinares. Os explantes incubados permanentemente em meio básico mantiveram o crescimento longitudinal durante o período experimental (Tabela 6 e Figura 48).
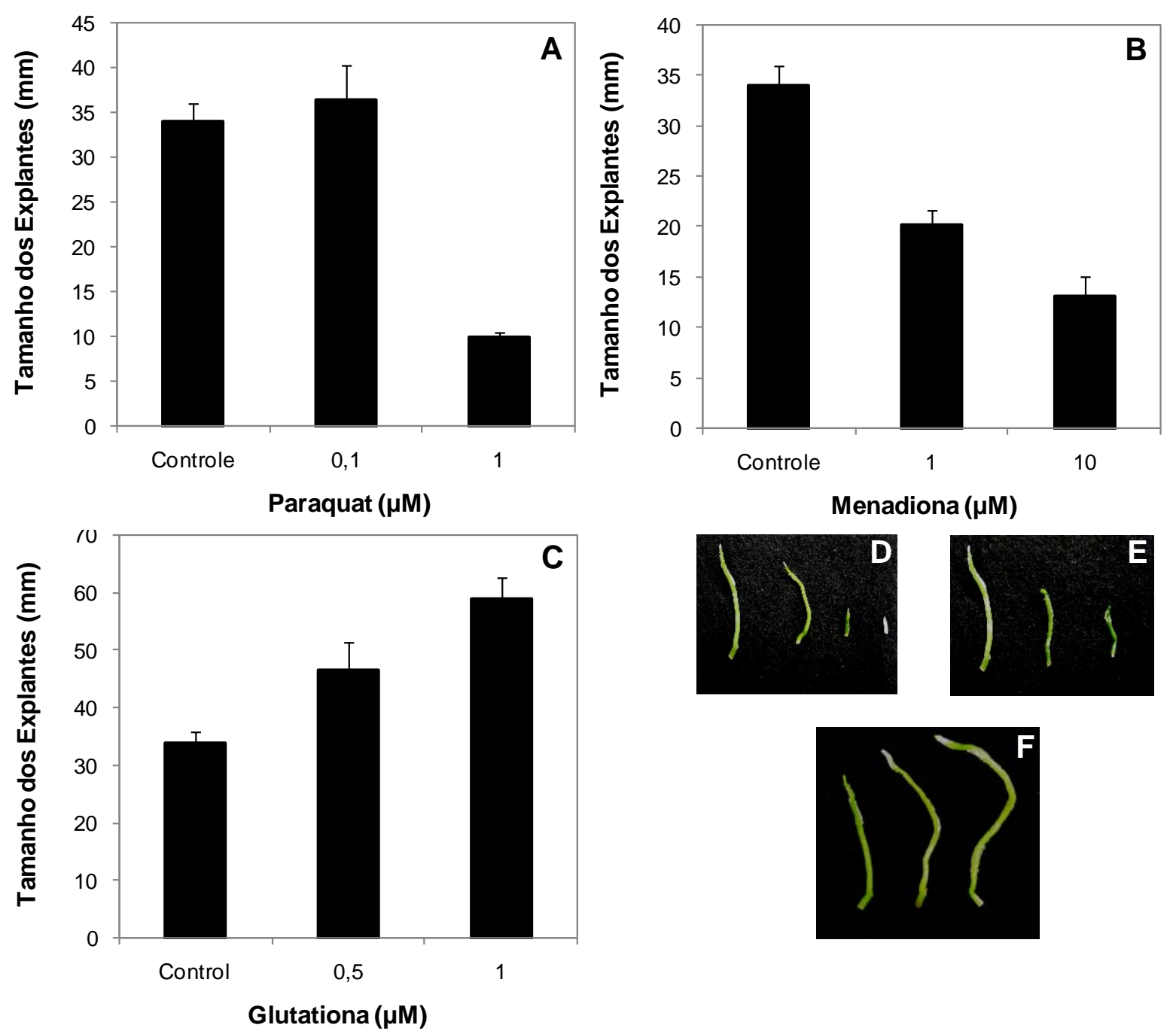

Figura 47: Comportamento de ápices radiculares isolados de plantas de C. fimbriatum com 30 dias de idade incubados por 60 dias na presença de diferentes substâncias moduladoras do estado redox celular: $(A)$ tamanho final dos explantes após tratamento com paraquat (B) tamanho final dos explantes após tratamento com menadiona; $(C)$ tamanho final dos explantes após tratamento com glutationa; $(D)$ fenótipo dos explantes após tratamentos com paraquat; (E) fenótipo dos explantes após tratamentos com menadiona e (F) fenótipo dos explantes após tratamentos com glutationa. As barras de erro indicam o erro padrão. 
O tratamento de ápices radiculares jovens com menadiona, uma substância capaz também de promover o estresse oxidativo, provocou a inibição do crescimento longitudinal dos explantes. Essa ação inibitória mostrou-se mais severa com o aumento da concentração de menadiona; no entanto, não foi observada a inibição total de crescimento dos explantes nas concentrações analisadas (Figuras 47B e 47E).

O tratamento com $1 \mu \mathrm{M}$ de menadiona resultou numa diminuição de cerca de $25 \%$ no crescimento longitudinal dos explantes, sendo que na presença de $10 \mu \mathrm{M}$ dessa substância, ocorreu a inibição da atividade do MAR de maneira mais conspícua, verificando-se uma redução de cerca de 50\% no crescimento dos ápices radiculares (Figura 47B). Além de inibir parcialmente a atividade do MAR de C. fimbriatum, a presença de menadiona provocou o intumescimento apical de parte dos explantes jovens, no entanto, não se observou a formação de gemas caulinares a partir dos ápices radiculares modificados durante o período experimental (Tabela 4).

Tabela 6: Porcentagem de ápices radiculares isolados de plantas de C. fimbriatum com 30 dias de idade que se apresentaram intumescidos ou convertidos em gemas caulinares após 60 dias de incubação na presença de $10 \mu \mathrm{M}$ menadiona ou $1 \mu \mathrm{M}$ de paraquat. Junto à média está indicado o erro padrão.

\begin{tabular}{ccc}
\hline Tratamento & \%MAR Intumescido & \%Conversão \\
\hline Controle & $0,0 \pm 0,0$ & $0,0 \pm 0,0$ \\
\hline $1 \mu \mathrm{M}$ Menadiona & $53,3 \pm 6,6$ & $0,0 \pm 0,0$ \\
\hline $10 \mu \mathrm{M}$ Menadiona & $36,7 \pm 4,8$ & $0,0 \pm 0,0$ \\
\hline 60 dias em $1 \mu \mathrm{M}$ de paraquat & $0,0 \pm 0,0$ & $0,0 \pm 0,0$ \\
\hline 30 dias em1 $\mu \mathrm{M}$ de paraquat + & $100 \pm 0,0$ & $100 \pm 0,0$ \\
30 dias em meio básico & & \\
\hline
\end{tabular}

Os tratamentos com 0,5 e $1 \mu \mathrm{M}$ de glutationa, por sua vez, estimulou o crescimento longitudinal dos ápices radiculares durante o período experimental, sendo que a concentração 
de $1 \mu \mathrm{M}$ dessa substância provocou um aumento no tamanho final dos explantes em cerca de $58 \%$ em relação ao controle (Figuras 47C e 47F).
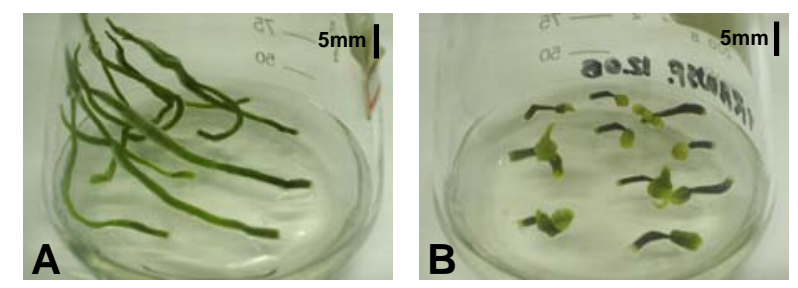

Figura 48: Fenótipo de ápices radiculares isolados de plantas de C. fimbriatum com 30 dias de idade; (A) após 60 dias de incubação em meio de cultura básico; e (B) após 30 dias de incubação em $1 \mu \mathrm{M}$ de paraquat, seguidos de 30 dias de incubação em meio de cultura básico.

\section{Variações nos teores de ascorbato e glutationa após o isolamento de ápices radiculares}

O isolamento de ápices radiculares competentes, provenientes de plantas com 120 dias de idade, elevou os teores endógenos de ascorbato (ASC) após o primeiro dia de incubação dos explantes, alcançando valores equivalentes ao triplo do conteúdo de ASC encontrado nos ápices radiculares recém-isolados da planta-mãe. Por outro lado, os teores de ASC diminuíram substancialmente após o primeiro dia de isolamento dos explantes nãocompetentes (provenientes de plantas com 30 dias de idade), alcançando ao terceiro dia de incubação valores cerca de três vezes menores do que foram aqueles observados nos explantes iniciais (Figura 49A).

Complementarmente, os teores endógenos de glutationa (GSH) não apresentaram um padrão de variação consideravelmente claro tanto nos explantes competentes quanto nos não-competentes para conversão. Apesar dos valores de GSH encontrados durante a maior parte do período experimental não ter diferido entre ambos os tipos de explantes, verificou-se um ligeiro aumento nos teores de GSH após a primeira hora de isolamento dos ápices radiculares não-competentes (Figura 49B). 

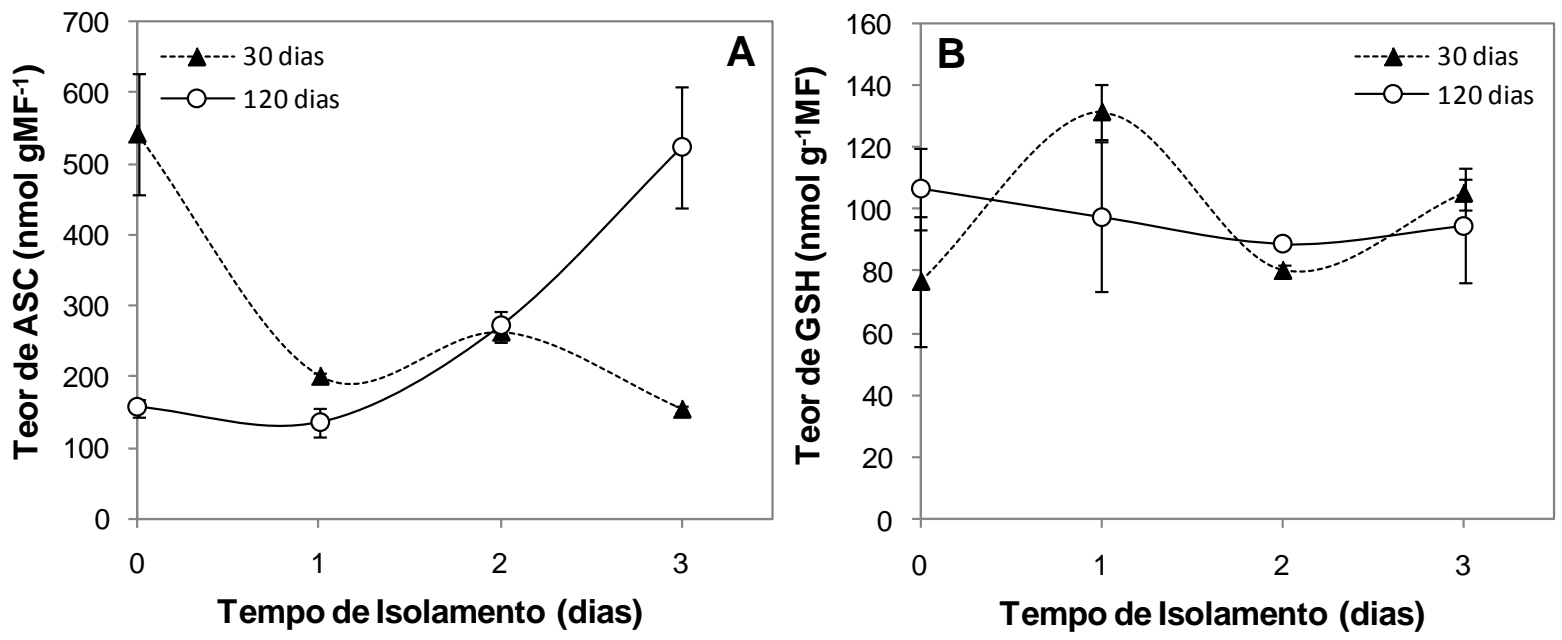

Figura 49: Variações nos teores endógenos de (A) ascorbato (ASC) e (B) glutationa (GSH) durante os três primeiros dias após o isolamento de ápices radiculares de plantas de $C$. fimbriatum com 30 dias (explantes não-competentes) e de 120 dias de idade (explantes competentes para conversão do MAR em gemas). Barras de erro indicam erro padrão.

\section{IV.7. Importância do óxido nítrico e do cálcio citossólico na aquisição de competência}

Efeitos do óxido nítrico no desenvolvimento in vitro de ápices radiculares de C. fimbratum

O tratamento de ápices radiculares não competentes, isolados de plantas com 30 dias de idade, com SNP (nitroprussiato de sódio, um doador de óxido nítrico), proporcionou respostas distintas nos explantes dependendo da concentração empregada.

Os tratamentos com 5 e $50 \mu \mathrm{M}$ de SNP conferiram aos ápices radiculares um crescimento longitudinal cerca de $30 \%$ superior ao observado nos ápices controle (Figura 50A), bem como estimularam o crescimento dos explantes em diâmetro (Figura 50B). Todavia, a presença de $100 \mu \mathrm{M}$ de SNP mostrou-se fortemente inibitória ao crescimento longitudinal dos ápices radiculares (Figura 50A), proporcionando o intumescimento apical na região meristemática (Figura 50B); no entanto, não houve formação de gemas a partir dessas estruturas arredondadas. 

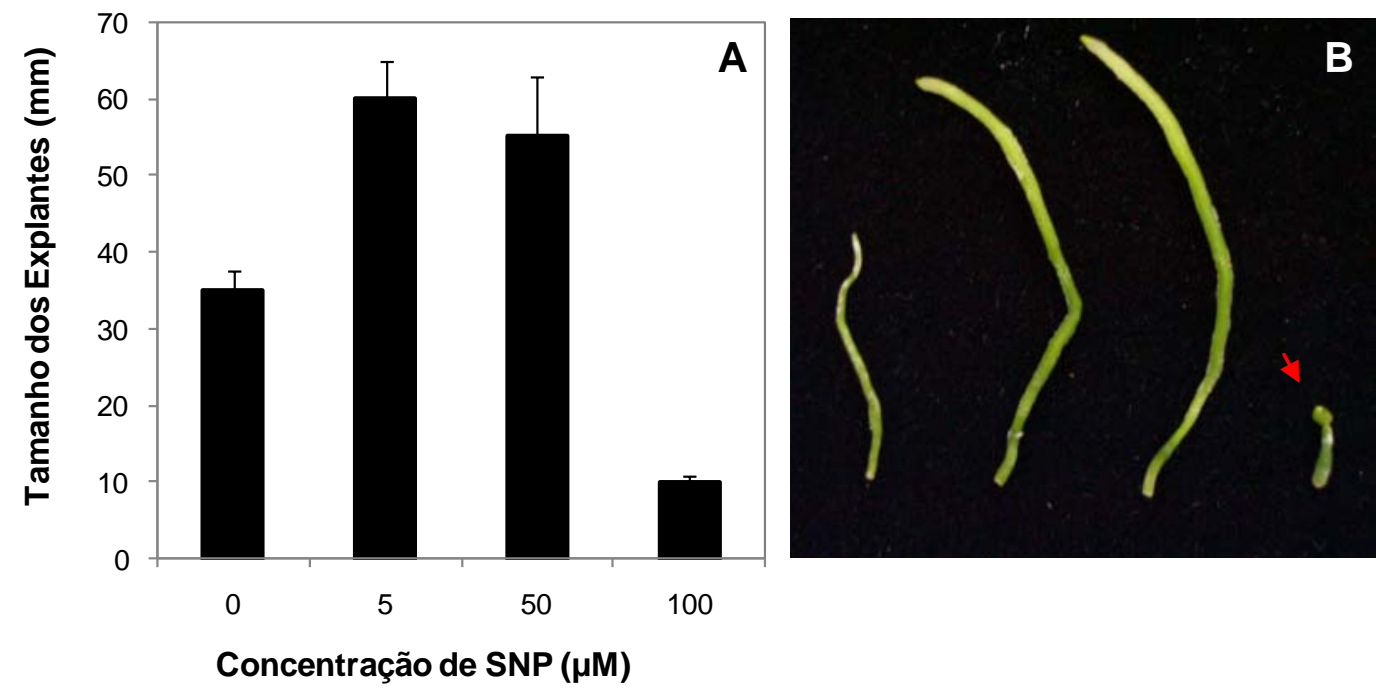

Concentração de SNP $(\mu \mathrm{M})$

Figura 50: Respostas de ápices radiculares isolados de plantas de C. fimbriatum com 30 dias de idade após 50 dias dos tratamentos com 0; 5, 50 e 100 $\mu$ M de SNP. (A) Tamanho final dos explantes. Barras de erros indicam erro padrão; (B) Fenótipo dos explantes. Seta vermelha indica região apical do explante intumescida.

Os tratamentos dos explantes jovens, isolados de plantas com 30 dias de idade, com 100 $\mu \mathrm{M}$ de CPTIO (carboxi-PTIO, uma substância sequestradora de óxido nítrico) revelaram que a diminuição nos teores endógenos de NO provocava a inibição do crescimento longitudinal dos explantes. No entanto, nesse tratamento não foi observado intumescimento da região meristemática dos ápices radiculares e nem sua conversão em gemas caulinares (Tabela 7).

Tabela 7: Tamanho de ápices radiculares isolados de plantas com 30 dias de idade $e$ porcentagem deles convertidos em gemas após 50 dias de incubação na presença de CPTIO. Junto à média está indicado o erro padrão.

\begin{tabular}{ccc}
\hline Tratamento & Tamanho $(\mathbf{m m})$ & \%Conversão \\
\hline Controle & $27,8 \pm 2,4$ & $0,0 \pm 0,0$ \\
\hline $100 \mu \mathrm{M} \mathrm{CPTIO}$ & $6,7 \pm 0,0$ & $0,0 \pm 0,0$ \\
\hline
\end{tabular}


Concentração relativa e localização do óxido nítrico na aquisição de competência e na conversão do MAR em gemas

As análises de localização in situ e quantificação relativa dos teores endógenos de óxido nítrico (NO) em ápices de raízes jovens (não-competentes para conversão em gemas) e maduros (competentes para conversão em gemas) mostraram que as concentrações desse radical livre eram mais elevadas nas células em diferenciação dos ápices radiculares de ambas as idades (Figura 51).

Nos ápices de raízes jovens, cujos MARs apresentaram características tipicamente meristemáticas, detectaram-se teores elevados de NO apenas nas regiões envolvidas com a diferenciação das células laterais da coifa (Figura 51F). Em contrapartida, nos ápices de raízes maduras verificou-se maior presença de NO nas células do sistema vascular em diferenciação próximo ao MAR e na região central do próprio MAR intumescido (Figura 51H). Nesse último caso, as células com maiores teores de NO encontravam-se na região anteriormente ocupada pelas células do centro quiescente (Figura 8L).

A localização do NO durante os estágios mais avançados de conversão revelou que o mesmo encontrava-se também, de maneira marcante, no primórdio radicular da gema em diferenciação (Figuras 52F e 52G), bem como nos cordões procambiais no interior do MAR intumescido, os quais, aparentemente, interligavam o explante radicular e a gema em formação (Figuras 52F e 52G). 


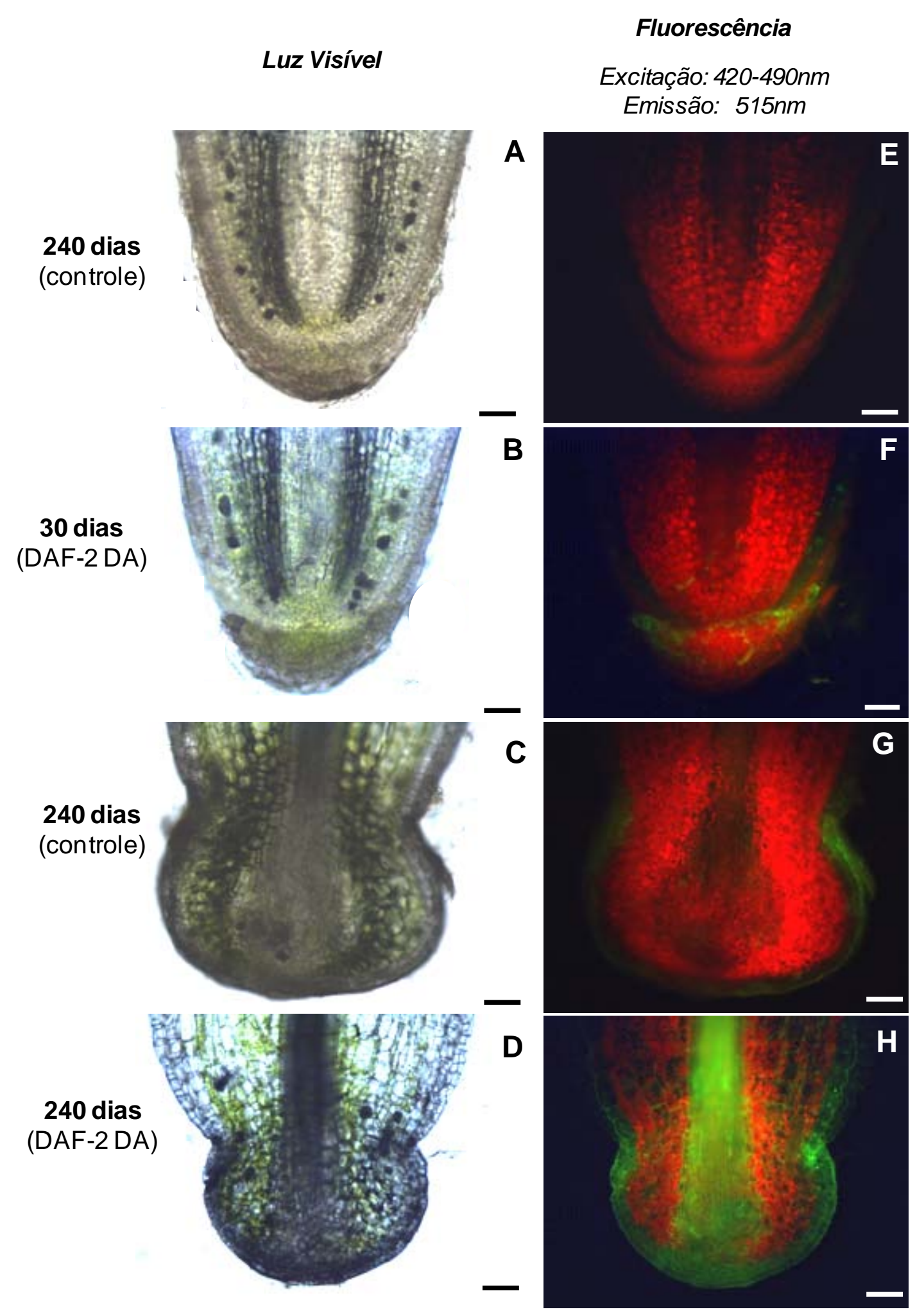

Figura 51: Localização de óxido nítrico por fluorescência em cortes longitudinais frescos, obtidos à mão-livre em ápices radiculares isolados de plantas de $C$. fimbriatum com 30 e 240 dias de idade. (A-D) luz visível; (E-H) excitação de 420-490nm e emissão de $515 \mathrm{~nm}$. Sendo que: ápices com 30 dias de idade sem ( $A$ e $E$ ) e com (B e F) pré-incubação em DAF-2DA; e ápices com 240 dias de idade sem $(C$ e $G$ ) e com ( $D$ e H) pré-incubação em DAF-2DA. Escala: $100 \mu \mathrm{m}$. 

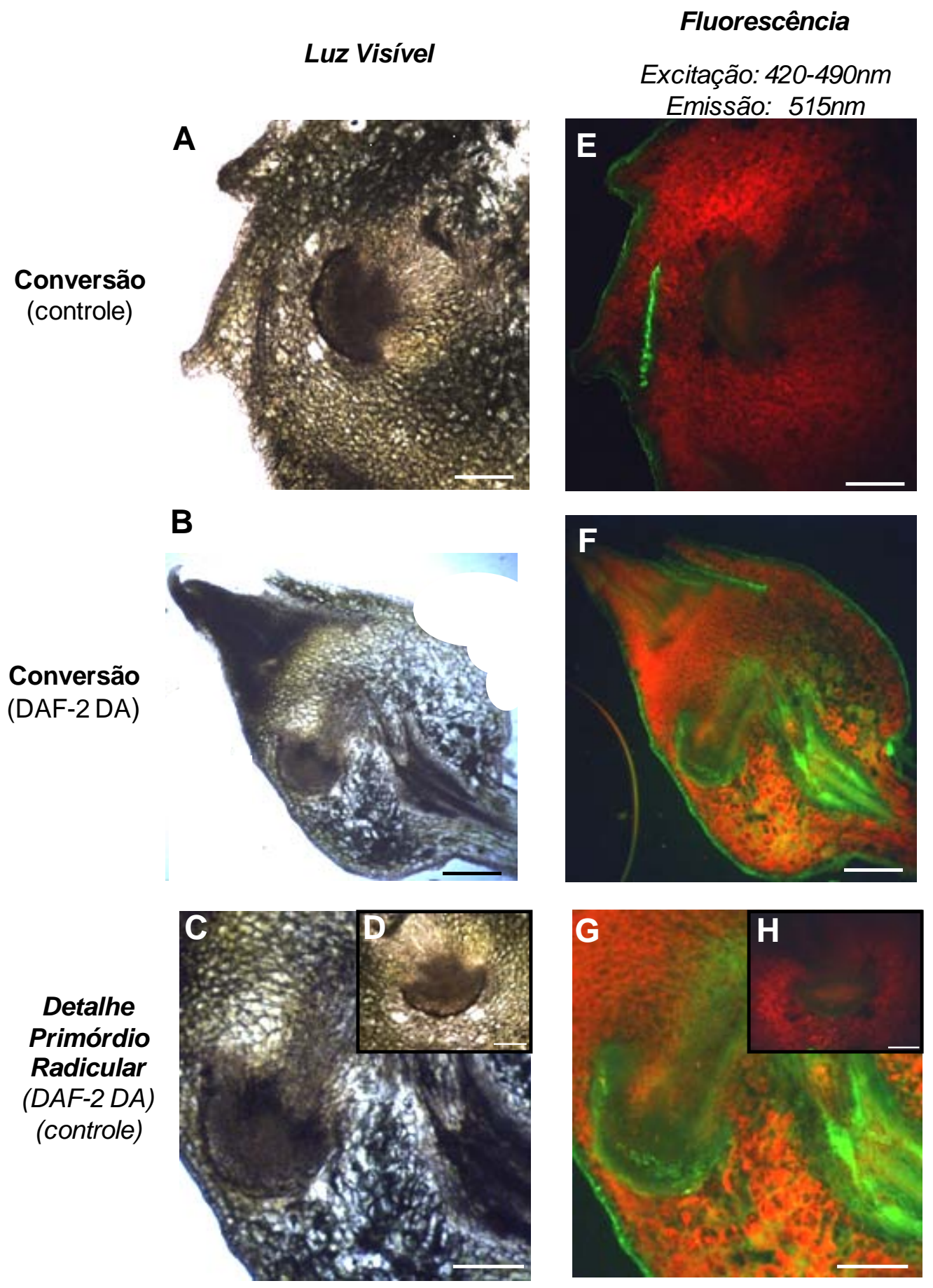

Figura 52: Localização de óxido nítrico por fluorescência em cortes longitudinais obtidos à mão-livre em ápices radiculares isolados de plantas de C. fimbriatum com 120 após 30 dias de inbubação em meio básico. Material fresco analisado sob microscopia de fluorescência. (A-D) luz visível; $(E-H)$ excitação de 420-490nm e emissão de 515nm. Sendo que: explantes sem (A, $E, D$ e $H$ ) e com (B, C, F e G) pré-incubação em DAF-2DA. Escala: $100 \mu \mathrm{m}$. 
Efeitos do cálcio citossólico no desenvolvimento in vitro de ápices radiculares de C. fimbratum

Tratamentos de explantes não-competentes (isolados de plantas com 30 dias de idade) com substâncias moduladoras da concentração de cálcio citossólico revelou que a presença de concentrações crescentes tanto de um quelante de cálcio citossólico (EGTA) quanto de um ionóforo de cálcio (ionomicina) provocou uma diminuição do crescimento longitudinal dos explantes (Figura 53).

Tratamentos com EGTA nas concentrações de 0,1 e 1mM resultaram na redução de cerca de $30 \%$ no tamanho final dos explantes, sendo que na presença de $10 \mathrm{mM}$ dessa substância, por sua vez, houve um decréscimo de cerca de 70\% (Figura 53A).

Dentre as concentrações empregadas de ionomicina, a de 1000nM foi a única capaz de provocar uma redução significativa no tamanho final dos explantes, sendo que essa diminuição foi de cerca de $70 \%$ do tamanho atingido pelos explantes controle (Figura 53B).
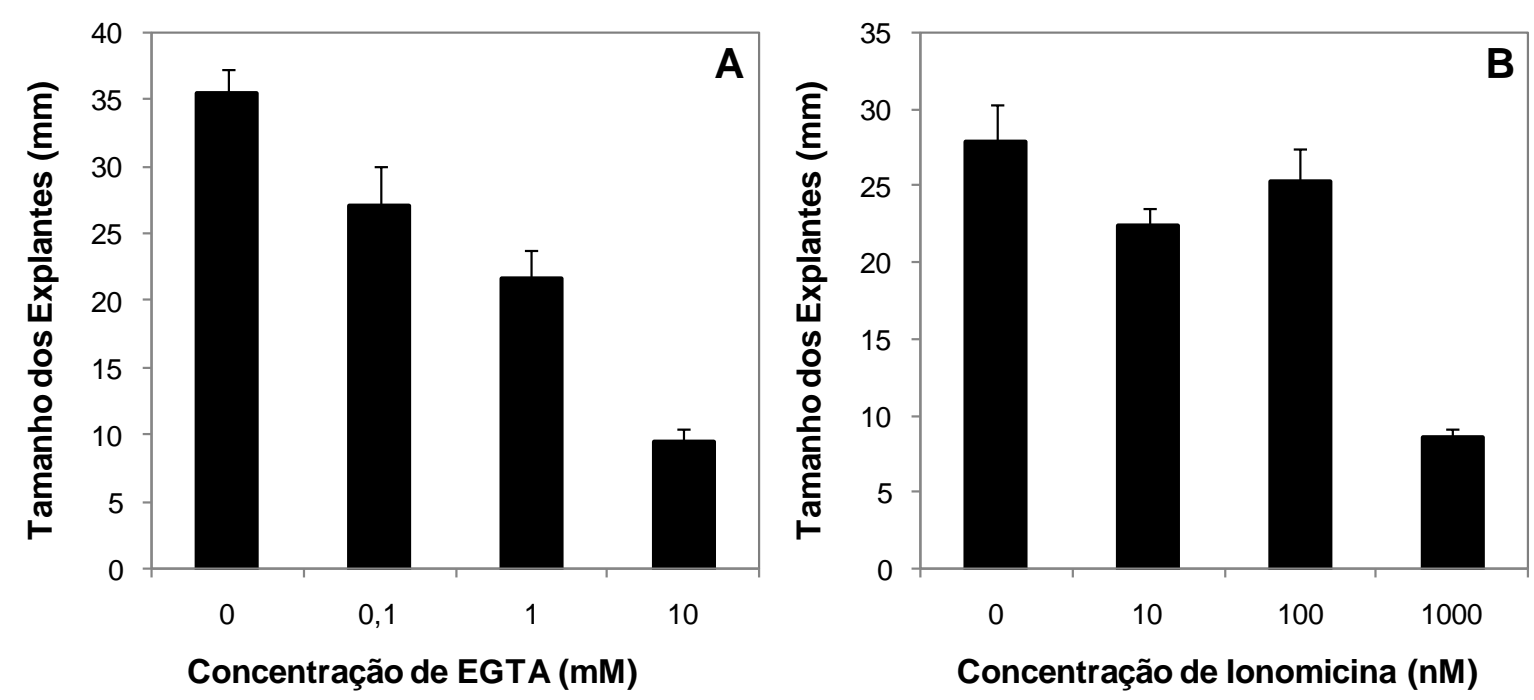

Figura 53: Tamanho final adquirido por ápices radiculares isolados de plantas de $C$. fimbriatum com 30 dias de idade após 30 dias de incubação na presença de (A) EGTA e (B) ionomicina. As barras de erro indicam o erro padrão.

Embora 10mM de EGTA tenha proporcionado a alteração da região apical dos explantes, com um intumescimento proeminente deste, não se observou a formação de 
gemas a partir dessas estruturas, portanto, não consolidando a conversão do MAR em gema caulinar. Por outro lado, a aplicação de 1000nM de ionomicina desencadeou a conversão de 100\% dos ápices radiculares em gemas caulinares (Tabela 8 e Figura 54).

No lugar da formação de gemas caulinares, o tratamento com 10mM de EGTA proporcionou o desenvolvimento de uma estrutura proliferativa parecida com calo (Figura 54B) e o tratamento com 1000nM de ionomicina, por sua vez, promoveu o desenvolvimento prioritário do sistema radicular das gemas formadas (Figura 54C).

Tabela 8: Porcentagem de conversão em ápices radiculares isolados de plantas de $C$. fimbriatum com 30 dias de idade, após 30 dias de incubação na presença $1 \mu M$ ionomicina $e$ $10 \mathrm{mM}$ de EGTA. Junto à média está indicado o erro padrão.

\begin{tabular}{cc}
\hline Tratamento & \%Conversão \\
\hline Controle & $0,0 \pm 0,0$ \\
\hline $1 \mu \mathrm{M}$ ionomicina & $100 \pm 0,0$ \\
\hline $10 \mathrm{mM}$ EGTA & $0,0 \pm 0,0^{*}$ \\
\hline
\end{tabular}

*presença de proliferações sem diferenciação de gemas caulinares.

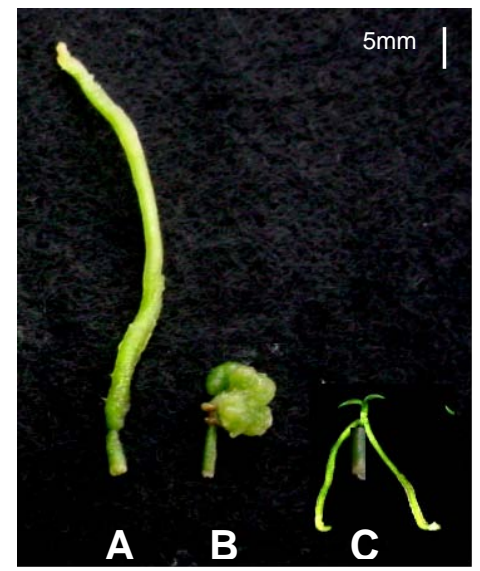

Figura 54: Fenótipo de explantes jovens de C. fimbriatum (isolados de plantas com 30 dias de idade) após 30 dias de incubação em (A) meio básico - controle; (B) $10 \mathrm{mM}$ de EGTA e (C) $1 \mu M$ ionomicina. 
Variações endógenas e localização do cálcio citossólico na aquisição de competência

Análises da distribuição e quantificação relativa dos teores endógenos de cálcio citossólico por meio da sua localização in situ em ápices de raízes jovens (não-competentes para conversão em gemas) e maduras (competentes para conversão em gemas) mostraram que esse mensageiro secundário, de forma semelhante ao NO, encontrava-se em concentrações mais elevadas nas células em processo de diferenciação de ápices radiculares isolados de plantas de 240 dias de idade (Figura 55).

Nos ápices de raízes jovens, cujos MARs apresentaram características tipicamente meristemáticas, verificou-se que mesmo na condição controle (sem a incubação com a substância marcadora de cálcio citossólico), detectou-se a presença de autofluorescência nas células correspondentes aos idioblastos, quando observados na faixa de comprimento de onda utilizada para detecção do fluoróforo de fluo-3 ligado ao cálcio citossólico (Figura 55B). Quando esse mesmo material foi incubado na presença da substância marcadora de cálcio citossólico não foi possível a verificação de um padrão de distribuição muito claro desse íon, parecendo nesse caso que suas concentrações foram reduzidas dentro do MAR (Figura 55D).

No entanto, quando ápices radiculares isolados de plantas com 240 dias foram analisados sob as mesmas condições, verificou-se que, não ocorria a autofluorescência dos idioblastos na condição controle (Figura55F), indicando a redução ou ausência desse tipo celular no MAR de raízes velhas. Também foi possível verificar que a incubação desse material com a substância marcadora de cálcio citossólico indicou a forte presença desse sinalizador nas células envolvidas com a diferenciação do velame, em toda a região de diferenciação do sistema vascular, especialmente na região vizinha àquela correspondente à localização do CQ (Figura 55H). 

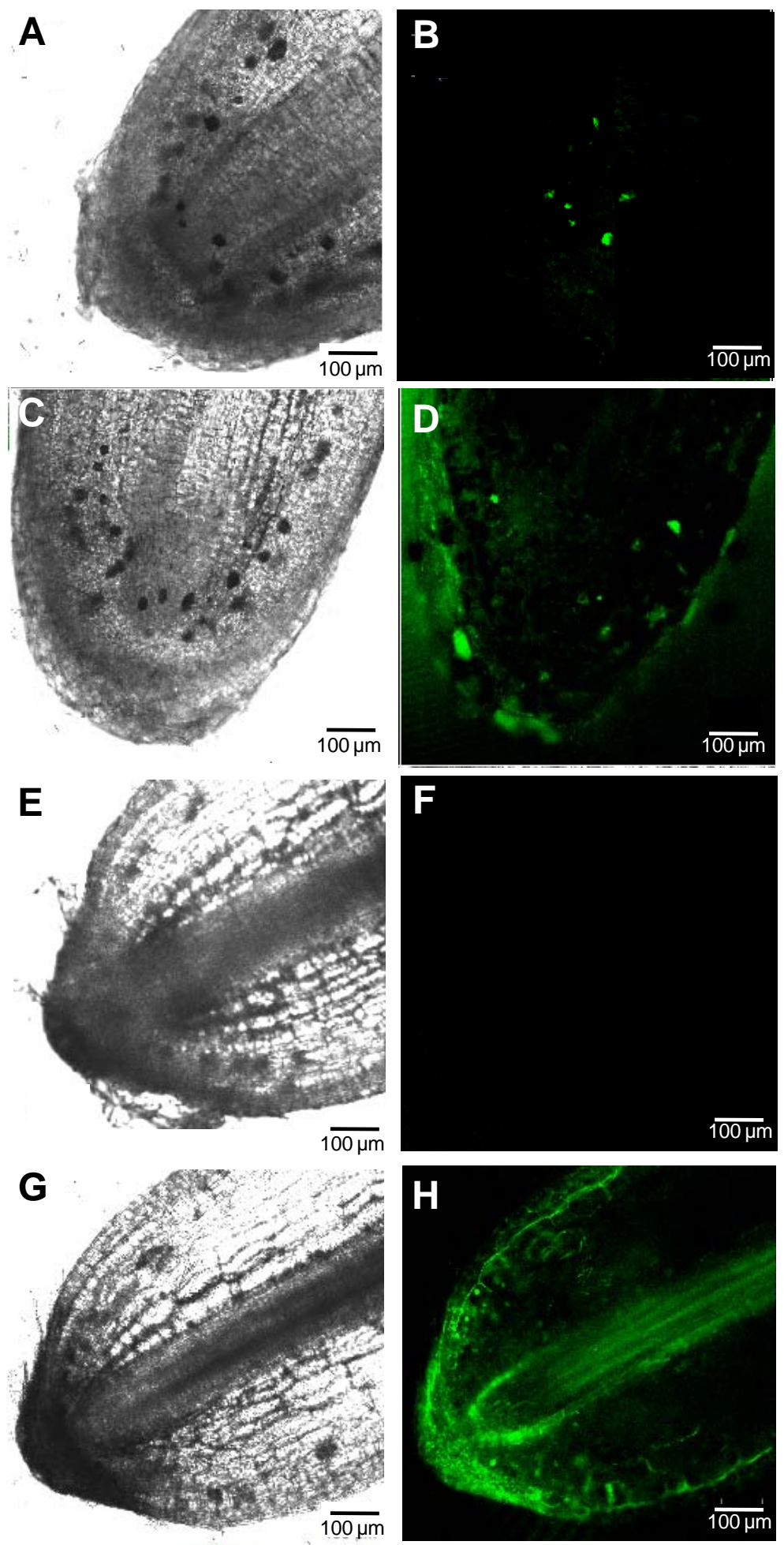

Figura 55: Localização de cálcio citossólico por fluorescência em cortes longitudinais de ápices radiculares recém-isolados de plantas de C. fimbriatum com 30 e 240 dias de idades. Material fresco analisado sob microscopia confocal. (A-D) 30 dias; (E-H) 240 dias de idade. Sendo que: (A, $C, E$ e $G$ : luz visível), (B, D, $F$ e $H$ : fluorescência em excitação de 488nm e emissão de 505-530nm), (A, B, E e F: Controle) e (C, D, G e H: incubados com fluo-3 AM). 
Mecanismos possíveis de controle da concentração de cálcio dentro do MAR jovem de C. fimbriatum

Em ápices radiculares isolados de plantas jovens de $C$. fimbriatum era comum a presença de um número considerável de idioblastos especializados na estocagem de cálcio na forma de oxalato de cálcio nas células do MAR (Figura 56).

Essas células especializadas localizavam-se na região de transição entre o meristema fundamental e a região de alongamento celular de ápices radiculares jovens, em fase de crescimento. A diferenciação precoce destes idioblastos pareceu ocorrer de maneira sincronizada, bem como apresentou uma distribuição espacial característica (Figuras 56A).

As várias fases de diferenciação desses idioblastos foram detectadas na terceira fileira de células mais externa do córtex, e esse processo de especialização celular pareceu ser iniciado de maneira muito precoce na região vizinha às células iniciais funcionais do MAR (Figura 56B).

A freqüência de células envolvidas nas diferentes fases de diferenciação dessas estruturas era notável. Esse processo de diferenciação pareceu coincidir com a fase de degeneração de corpúsculos densos no interior dos citoplasmas de suas células formadoras (Figura 56C), dando lugar ao acúmulo de ráfides de oxalato de cálcio no interior de seus vacúolos (Figura 56D-56F). 

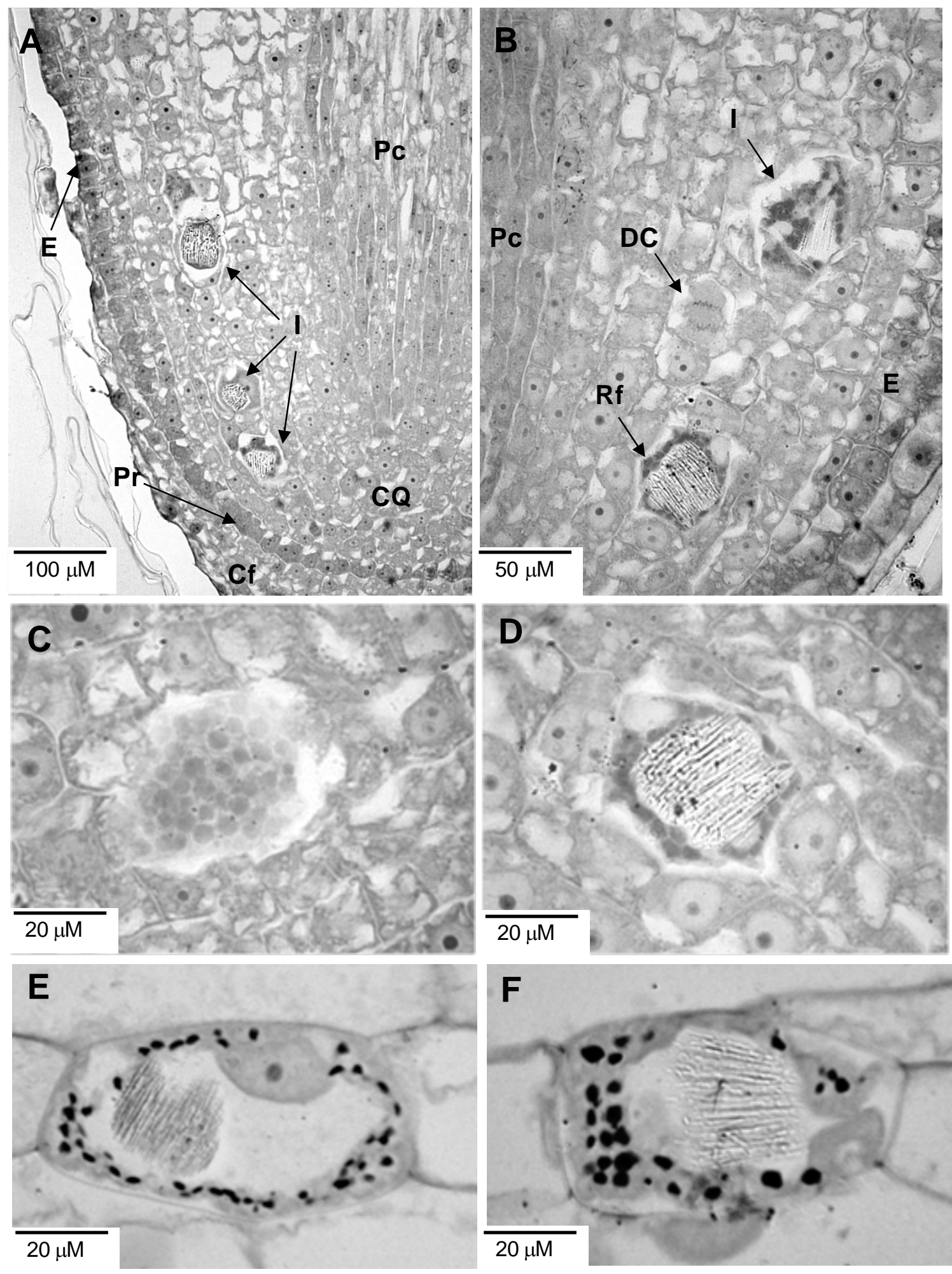

Figura 56: Detalhes do ápice radicular recém-isolado de plantas com 30 dias de idade. (A) localização geral de idioblastos com ráfides de oxalato de cálcio; (B) detalhe de idioblastos nas camadas mais externas do tecido que se diferenciará em córtex, localização próxima de divisões celulares (DC); (C), (D), (E) e (F) diferentes estágios de diferenciação de idioblastos no MAR. 


\section{DiscussÃo}

A conversão do meristema apical radicular (MAR) em gemas caulinares é um evento de organogênese raro, porém encontrado nos ápices radiculares de orquídeas do gênero Catasetum (KERBAUY, 1984), o qual tem representado um modelo interessante para o estudo dos sinais ambientais e endógenos que controlam tanto a manutenção do MAR quanto o estabelecimento de um meristema caulinar.

Em estudos anteriores conduzidos com esse modelo verificou-se que a conversão do MAR em gema caulinar ocorria, espontaneamente, quando os ápices radiculares eram isolados da planta-mãe e, posteriormente, incubados em meio de cultura básico (KERBAUY, 1984). A partir dessa descoberta inicial, estudos complementares permitiram interpretações de que os referidos ápices radiculares já possuíam competência para converterem-se em gemas caulinares. Além disso, alguns resultados indicaram que o isolamento destes explantes desencadeava o estabelecimento de um balanço hormonal endógeno específico, o qual promoveria a conversão do MAR em gemas caulinares por meio do favorecimento dos teores de citocininas em detrimento dos de auxinas (PERES e KERBAUY, 1999). No entanto, as demais variáveis que confeririam a capacidade rara de conversão direta do MAR em gemas caulinares nessas plantas eram desconhecidas.

O conjunto de dados obtidos nesse trabalho de pesquisa possibilitou um entendimento parcial de alguns parâmetros ligados à aquisição de competência para o desencadeamento desse evento organogênico. Tal avanço foi possível devido à descoberta de que os ápices radiculares de Catasetum fimbriatum representam estruturas dinâmicas, as quais sofrem modificações profundas no crescimento, morfologia e fisiologia à medida que envelhecem durante o cultivo in vitro. Os resultados ora apresentados indicaram que as mudanças observadas durante o processo de envelhecimento radicular dessa espécie estiveram 
intimamente relacionadas à aquisição de competência para a formação de uma gema caulinar a partir do seu MAR.

Ao contrário do que se sabe para a maioria das espécies vegetais, cuja maior competência para organogênese se encontra em tecidos mais jovens (KERBAUY, 1999), verificou-se que a competência para conversão do MAR de C. fimbriatum em gema caulinar aumentava à medida que os ápices radiculares envelheciam (Figura 4). Constatou-se, por exemplo, que ápices radiculares de plantas com idade entre 30 e 60 dias, em regra, apresentaram baixa competência para a conversão após o isolamento da planta-mãe (Figura 4E). Esses explantes mantiveram o crescimento longitudinal radicular durante grande parte do período de incubação (Figura 4B). Por outro lado, a maioria dos explantes isolados de plantas com 120 e 240 dias de idade foi capaz de se converter em gemas logo após o isolamento da planta-mãe (Figuras 4E), sem apresentar crescimento longitudinal radicular (Figura 4D).

As diferenças observadas na competência organogênica nessas raízes coincidiram com o estabelecimento de padrões morfológicos diferenciados entre os dois tipos de explantes, os quais eram possíveis de ser distinguidos a olho nu. Explantes que não apresentaram competência para se converter (isolados de plantas jovens) apresentaram coloração verde claro e região apical com formato cônico (Figura 4A), ao passo que aqueles que possuíram tal competência (isolados de plantas mais velhas) apresentaram coloração verde escura e a região apical com formato achatado (Figura 4C).

A clara perda do vigor dos ápices radiculares ao longo do envelhecimento foi acompanhada, entre outros fatores, pela redução significativa nas massas fresca e seca (Figuras 6A e 6B, respectivamente), no conteúdo relativo de água (Figura 6C), teores de proteínas e de amônio (Figuras 6D e 6E, respectivamente), bem como pela diminuição na assimilação de nitrato decorrente da redução na atividade da nitrato redutase (Figura 6F). As alterações observadas nesses compostos endógenos coincidiram tanto com a redução do pH 
(Figura 7A) quato dos teores de amônio (Figura 7B) no meio de cultura onde as raízes eram mantidas.

Apesar de não ter sido analisado nesse trabalho as variações de outros componentes essenciais do meio de cultura durante o desenvolvimento das plantas in vitro, supõe-se, com base nos dados obtidos de redução do $\mathrm{pH}$ e de amônio, que também possa ocorrer alterações de importantes macro e micronutrientes, fonte de carboidratos, potencial osmótico, compostos fenólicos, entre outros fatores do meio de cultura capazes de afetar de maneira determinante o desenvolvimento radicular das plantas de C. fimbriatum cultivadas in vitro.

Segundo KANDLBINDER et al. (2004), a deficiência nutricional pode afetar de duas maneiras distintas o metabolismo e o desenvolvimento das plantas. A primeira ocorreria quando as plantas coordenam a deficiência nutricional durante uma resposta adaptativa, resultando em um número reduzido de órgãos, no entanto, devido a um processo de reciclagem rápida de nutrientes provenientes dos órgãos mais velhos o metabolismo geral não é afetado. A segunda forma, por sua vez, ocorreria de maneira desbalanceada, caracterizando um desenvolvimento problemático com disfunção na planta inteira, a qual estaria sob estresse. Dessa forma, é possível que o aumento da competência do MAR de $C$. fimbriatum para conversão em gemas caulinares durante o envelhecimento radicular extremado envolva, entre outros fatores, condições que propiciem estresse aos tecidos radiculares.

Além das mudanças supracitadas nos explantes e no meio de cultura durante o envelhecimento da cultura in vitro, observou-se que a aquisição de competência para conversão do MAR também esteve relacionada a um processo intenso de diferenciação dos tecidos ao longo do envelhecimento radicular, o qual ocorreu de maneira concomitante à perda gradativa da coifa (Figuras 5A-5D, 8A, 8D, 8G e 8J). Pode-se verificar, por exemplo, um aumento conspícuo na presença de clorofila nas células pertencentes à região apical das raízes mais velhas (Figuras $8 \mathrm{~B}, 8 \mathrm{E}, 8 \mathrm{H}$ e $8 \mathrm{~K}$ ), bem como de células diferenciadas ou em 
processo de diferenciação, as quais participaram no incremento dos feixes vasculares, córtex ou células de revestimento da raiz (Figuras $8 \mathrm{C}, 8 \mathrm{~F}, 8 \mathrm{I}$ e $8 \mathrm{~L}$ ).

As modificações ocorridas na região apical dos explantes estiveram também fortemente relacionadas com a fase de vida das raízes e com sua dinâmica de crescimento ao longo do desenvolvimento in vitro das plantas. Verificou-se que as raízes de C. fimbriatum mantidas sob as condições de cultivo em questão estabeleceram o crescimento determinado à medida que envelheceram, sendo o período de maior crescimento compreendido entre as idades de 30 e 50 dias (Figura 3). Tais fatores indicaram que o MAR de plantas nessa faixa de idade possuiu uma maior atividade mitótica das iniciais funcionais, proporcionando o aumento do crescimento longitudinal das raízes por meio da formação de novas células destinadas ao alongamento e, finalmente, à diferenciação dos tecidos radiculares maduros.

Esses dados são coerentes com as análises histológicas realizadas em ápices radiculares isolados de plantas com 30 dias de idade. Segundo as informações obtidas nessa abordagem, observaram-se figuras mitóticas na região que abrange o meristema fundamental (Figura 11A-11C), sendo que a maioria das células observadas nesse tecido apresentava um conjunto de características tipicamente meristemáticas (Figuras 9A e 10A), ou seja, células pequenas, isodiamétricas, com citoplasma denso e núcleos proeminentes (CLOWES, 1981).

Complementarmente, esses explantes jovens apresentaram uma organização apical muito bem definida, onde foi possível discernir as fileiras de células iniciais que originariam os diferentes tecidos radiculares, bem como o ponto de convergência dessas fileiras no centro do meristema (Figura 9A), o qual, provavelmente, representou a região do centro quiescente (CQ). Também foi possível a visualização de uma clara separação entre as células do meristema fundamental daquelas que faziam parte da coifa (Figura 10A). Esse conjunto de constatações indicou que o MAR de explantes jovens apresentou, segundo definição feita por CLOWES (1981; 1982), uma organização tipicamente fechada. 
Diversos trabalhos têm evidenciado que plantas jovens de diferentes espécies, como Arabidopsis thaliana, Zea mays, Clarkia unguiculata, Oxalis laxua, Dianthus caryophyllus, Blumenbachia hieronumi, entre outras, apresentam organização do MAR do tipo fechada durante a fase de crescimento acelerado das raízes em decorrência de freqüentes divisões seguidas de alongamento celular (BAUM et al., 2002; CHAMPMAN et al., 2003; JIANG e FELDMAN, 2005). Um exemplo clássico desse evento foi dado por BAUM e colaboradores (2002), os quais observaram que ápices radiculares de plântulas de $A$. thaliana apresentavam uma organização do MAR do tipo fechado, no entanto, essa região perdeu parcialmente a organização celular à medida que as raízes se tornaram mais velhas, passando a ser aberta. ROST e BAUM (1988) observaram que a forma e o tamanho do MAR em plantas de ervilha mudavam com o envelhecimento da raiz primária. ARMSTRONG e HEMSCH (1976) e SEAGO e HEIMSCH (1969) verificaram em algumas espécies de plantas herbáceas que a organização do MAR dependia da idade e do tamanho da raiz.

As raízes analisadas de C. fimbratum apresentaram uma intensa desaceleração no crescimento a partir do $60^{\circ}$ dia de idade (Figura 3), corroborando, dessa forma, a constatação histológica de um encurtamento severo da região que englobava as iniciais funcionais do MAR e a região de alongamento nesse período. Essa região apresentou um aspecto ligeiramente diferenciado, refletido por células maiores e mais vacuoladas, muito semelhantes àquelas observadas no tecido cortical localizado na região mais madura do tecido (Figura 9B). Essas células parcialmente diferenciadas estiveram presentes no lugar antes ocupado pelas células em alongamento e por iniciais funcionais com forte atividade mitótica presentes no tecido mais jovem, sendo que as células em processo de diferenciação avançaram até uma região próxima ao CQ (Figuras 9B e 10B).

Apesar dessas modificações, verificou-se que os ápices radiculares isolados de plantas com 60 dias de idade ainda mantinham a organização original do MAR do tipo fechada (Figura 10B). Essa observação mostrou-se coerente com os resultados de 
crescimento radicular obtidos, uma vez que, embora se tenha observado certa desaceleração do crescimento radicular a partir do $60^{\circ}$ dia de idade, as raízes ainda apresentaram algum crescimento longitudinal (Figura 3). Essa observação indicou que os ápices radiculares nessa idade ainda possuiriam atividade mitótica no MAR e/ou alongamento celular, proporcionando algum crescimento das raízes com essa idade.

O crescimento radicular cessou quando as plantas alcançaram cerca de 85 dias de idade, indicando, dessa forma, que nessa fase as raízes atingiram o crescimento determinado (Figura 3). A análise histológica de ápices radiculares isolados de plantas com 120 dias de idade indicou a presença de alterações no padrão de organização do MAR, uma vez que nessa idade era possível observar mudanças estruturais nas células da região apical dos explantes (Figura 9C). O MAR nesse estágio apresentou uma organização do tipo intermediária-aberta, uma vez que não foi possível traçar claramente uma delimitação entre as células centrais da coifa e as do CQ, existindo apenas uma delimitação parcial nas bordas do meristema feita por células de uma provável epiderme já diferenciada (Figura 10C).

Raízes de $A$. thaliana também apresentaram modificações na organização do MAR durante o crescimento e envelhecimento das plantas, levando a uma maior desorganização nas fileiras de células iniciais do meristema. Essa desorganização esteve especialmente presente na região das células iniciais centrais associadas à formação do córtex, caracterizando um MAR do tipo intermediário-aberto (ZHU et al., 1998). A desorganização das células dentro do meristema radicular ao longo do envelhecimento parece ser um evento relativamente comum entre as espécies vegetais, sendo freqüentes os relatos de desorganização na distribuição das camadas de células no MAR conforme a raiz envelhece e o crescimento cessa (BAUM, 1996; SEAGO e HEIMSCH; 1969). Esses eventos freqüentemente resultam no isolamento simplástico das células devido a uma diminuição na freqüência de plasmodesmas nas paredes celulares do MAR após atingir seu crescimento determinado (ZHU et al.; 1998). 
O MAR de plantas de C. fimbriatum com 240 dias de idade, quando comparado à mesma região de plantas mais jovens, apresentou uma profunda desorganização na sua estrutura original, com a região onde se encontravam as iniciais funcionais totalmente modificada, sendo que essas células, aparentemente, diferenciaram-se quase que em sua totalidade em células parenquimáticas (Figura 9D). Na região onde se localizava o meristema verificou-se a existência de algumas poucas células com características meristemáticas (Figura 10D), as quais pareceram ter sido originadas a partir da perda da quiescência do CQ, uma vez que seu posicionamento dentro do MAR modificado correspondia à região antes ocupada pelo CQ nos MARs jovens (Figuras 12A e 12B).

De encontro a essa hipótese, o mesmo conjunto de células em questão, com características meristemáticas remanescentes no centro do MAR modificado, pareceram ser as únicas metabolicamente mais ativas no MAR de raízes de plantas com 240 dias de idade. Essa possibilidade foi aventada levando-se em consideração o fato de que essas células apresentaram uma maior concentração de proteínas, quando comparadas às células diferenciadas presentes ao seu redor (Figura 12D). Na realidade, as células diferenciadas em parênquima no MAR alterado possuíram um conteúdo protéico extremamente reduzido em relação aquele detectado nas células do MAR isolado de plantas com 30 dias de idade (Figuras 12D e 12C, respectivamente).

Dessa forma, esse grupo de células meristemáticas remanescentes dentro do meristema mais velho poderia estar envolvido na reorganização do MAR para a formação do primórdio de gema caulinar. Essa reorganização meristemática foi possível de ser percebida mesmo a olho nu durante o processo de conversão de ápices radiculares isolados de plantas com 120 dias de idade (Figura 13). As alterações meristemáticas ocorridas após o isolamento de explantes competentes resultaram em um intumescimento conspícuo da região apical (Figura 14A), sendo que a partir dessa estrutura observou-se a formação de uma nova planta, que em período breve, se torna independente do explante inicial (Figura 14B). 
Analisando-se em maior detalhe os eventos histológicos relacionados ao intumescimento dos ápices radiculares durante a conversão, verificou-se que após 10 dias de isolamento de explantes competentes, isolados de plantas com 120 dias de idade, foi possível a visualização de um grupo de células meristemáticas localizadas na região centro-periférica do parênquima diferenciado a partir das células do MAR e, apesar de não ter sido visualizada nenhuma figura mitótica, as células pareciam se encontrar em proliferação da região central para a periferia (Figura 15F). Ainda na porção periférica dessa estrutura globular foi possível a visualização de um primórdio de gema caulinar (Figura 16A-16D), confirmando a similaridade desse evento em C. fimbriatum e o anteriormente relatado para C. pileatum, de acordo com KRAUS e MONTEIRO (1989).

Segundo KRAUS e MONTEIRO (1989), as divisões celulares envolvidas na formação da estrutura globular a partir do MAR de C. pileatum já eram observadas por volta do terceiro dia do isolamento dos explantes, sendo que o início, aparentemente, teria ocorrido em período anterior, envolvendo as células da região do CQ. Esse conjunto de células meristemáticas foi considerado pelas autoras como sendo responsável pela formação da gema caulinar, sendo que após 10 dias de isolamento o ápice radicular foi considerado uma nova estrutura, a qual foi denominada de "estrutura semelhante à protocormo" (da tradução do Inglês "protocorm-like-bodies", ou simplesmente PLBs), devido a uma possível semelhança desse tecido àquelas estruturas resultantes da germinação de orquídeas (protocormos). Outros trabalhos que abordaram o mesmo processo de conversão de ápices radiculares em gemas caulinares também utilizaram o termo PLB para designar esse tipo de organização tecidual (KERBAUY, 1984; KRAUS e MONTEIRO, 1989; COLLI e KERBAUY, 1993; KERBAUY e ESTELITA, 1996; KERBAUY e COLLI, 1997).

No entanto, com base nos resultados observados, o novo arranjo apical das células pareceu decorrer do intumescimento do MAR de C. fimbriatum causado, pelo menos em parte, pela expansão e diferenciação das células da antiga região do MAR em parênquima, 
bem como por novas divisões celulares seguidas de diferenciação. Dessa forma, a estrutura globular que se formou poderia ser considerada o próprio ápice radicular alterado e com perda de função radicular. É plausível supor que tais modificações ocorram devido à capacidade que esse MAR possuiria de responder às variações de certos sinais posicionais responsáveis pela determinação do destino das células que o compõe, possivelmente por meio do aumento da taxa de divisões das células do CQ.

Com o objetivo de se estudar as primeiras modificações histológicas após o isolamento de ápices radiculares competentes (isolados de plantas com 120 dias de idade), foram realizadas análises dos explantes após as primeiras horas de seu isolamento da plantamãe. Deve-se ressaltar que esse delineamento experimental foi pautado no fato de que se acreditava que o isolamento dos ápices radiculares da planta-mãe seria a única maneira de desencadear a conversão do MAR de C. fimbriatum em gemas caulinares in vitro (KERBAUY, 1984; COLLI e KERBAUY, 1993). Além disso, sabia-se da possibilidade de formação de gemas vegetativas a partir de ápices radiculares ainda ligados a plantas de $C$. fimbriatum incubadas no escuro (SUZUKI et al., 2004), assim como poderia ocorrer, de maneira eporádica, em pontas de raízes de plantas cultivadas sob condições de ripado (comunicação pessoal).

Dessa forma, observou-se que 12 horas após o isolamento dos explantes radiculares (obtidos de plantas com 120 dias de idade) e incubação em meio básico foram suficientes para desencadear alterações visíveis na organização apical (comparando-se aos ápices de 120 dias de idade recém-isolados da planta-mãe), com a perda total do limite que separava as células da coifa e do CQ (Figuras 15B e 15A, respectivamente). A região do CQ não foi mais claramente distinguível, tão pouco as iniciais funcionais que originariam as diferentes fileiras de tecidos da raiz. Esse período de isolamento dos explantes também pareceu desencadear modificações no aspecto geral das células meristemáticas, uma vez que elas 
tornaram-se maiores, ligeiramente vacuoladas, e com formato mais arredondado (Figura 15B), indicando que poderiam ter entrado em um processo inicial de diferenciação.

Todas as modificações observadas durante esse breve período do isolamento dos explantes deram respaldo ao fato de que o MAR de $C$. fimbriatum passou de uma organização do tipo intermediária-aberta (antes do isolamento) para totalmente aberta. De acordo com essa proposta, estudos têm demonstrado que raízes de muitas plantas alcançaram o crescimento determinado após poucas semanas de idade, sendo que em algumas delas esse evento foi precedido pela ativação das células do CQ, resultando em uma mudança da organização do MAR do estado fechado para o aberto (BARLOW, 1997; BAUM et al., 2002). Segundo esses estudos, o MAR do tipo aberto apresentou perda das características típicas do posicionamento e aspecto das células do $\mathrm{CQ}$, bem como se verificaram a desorganização e vacuolização das células que ocupavam a região bem próxima à coifa; nesse momento considerou-se nessas espécies que o nicho das células iniciais foi perdido, a raiz cessou o crescimento e houve o estabelecimento do crescimento radicular determinado (BAUM et al. 2002).

A pré-disposição de modificações da organização e nos aspectos celulares do MAR observada em explantes isolados por 12 horas (Figura 15B) manteve-se em ápices radiculares com 24, 36 e 48 horas de isolamento (Figuras 15C, 15D e 15E, respectivamente). No entanto, nesses últimos tratamentos foi possível observar que o isolamento também provocou a perda gradativa da coifa (Figuras 15C-15E). Verificou-se que a partir da $24^{\mathrm{a}}$ hora do isolamento foi notável o início do desprendimento de células na região lateral da coifa (Figura 15C), sendo que após 36 horas de isolamento observou-se uma redução severa no número de células dessa estrutura, restando apenas algumas poucas na região central do ápice radicular (Figura 15D). Finalmente, explantes isolados por 48 horas mostraram-se totalmente desprovidos de coifa (Figura 15E). 
O desaparecimento da coifa parece refletir a ocorrência de algum evento importante para o estabelecimento da competência, visto que esse evento foi observado em ápices radiculares isolados por 48 horas, naqueles ligados de plantas com 240 dias de idade, foi também foi constatado por KRAUS e MONTEIRO (1989) durante a conversão de ápices radiculares isolados de C. pileatum, bem como por KERBAUY e ESTELITA (1996) durante o início do evento de mesma natureza em ápices radiculares isolados de Clowesia warscewiczii.

Há a possibilidade de que o desaparecimento da coifa seja um forte indício de que durante o envelhecimento, assim como durante o tempo de isolamento dos explantes, tenha ocorrido a perda funcional do CQ, o qual não seria mais capaz de formar novas células para reposição das iniciais da coifa e, conseqüentemente, dessa estrutura per se. Alguns relatos indicam que quando a coifa é eliminada mecanicamente, o $\mathrm{CQ}$ se divide com maior freqüência para regenerar uma nova coifa, sugerindo, dessa forma, que sinais provenientes e processados nessa estrutura poderiam ser importantes na manutenção tanto do caráter quiescente quanto indiferenciado das células no CQ (BARLOW, 1974; FELDMAN, 1976). De fato, observou-se que a ablação de uma ou mais células do CQ de A. thaliana causava uma rápida parada de divisão das células adjacentes presentes na columela e essas entraram em diferenciação (van den BERG et al. 1995). Em experimentos em que a coifa e o CQ foram eliminados, por sua vez, uma nova coifa se refez, mas não até que um novo CQ se desenvolvesse, levando à sugestão de que o CQ funcionaria como um organizador central do MAR (FELDMAN, 1976; 1998).

Com base nos dados da literatura relacionada, nas modificações observadas no MAR de C. fimbriatum durante o envelhecimento e naquelas ocorridas logo após o seu isolamento da planta-mãe, sugere-se que a seqüência de modificações induzidas pelo isolamento de explantes com certo grau de competência seja muito semelhante àquela que ocorre naturalmente no meristema de raízes mais velhas ainda ligadas à planta-mãe. Dessa forma, 
as análises histológicas dos explantes logo após as primeiras horas do isolamento indicaram que a separação dos ápices radiculares da planta-mãe parece ter um efeito acelerador sobre o processo de complementação da competência e sobre a conversão per se, equivalente àquele que ocorre naturalmente com as raízes ao longo do envelhecimento radicular extremado, envolvendo em ambos os casos a desorganização do MAR até ser alcançado o padrão radicular aberto, com diferenciação de parte das células do meristema fundamental e possível perda da quiescência das células do CQ.

A diferença de sincronização observada entre o tempo necessário para que cada explante inicie o processo de conversão em gemas caulinares pareceu decorrer do grau de modificações que o MAR de cada explante sofreu ao longo do período em que esteve ligado à planta-mãe, o qual refletiria diferentes graus de competência para esse tecido se converter em gemas caulinares. Desse modo, o que foi denominado nesse trabalho de explantes nãocompetentes para conversão corresponderia aos ápices radiculares cujos MARs não teriam alcançado ainda o crescimento determinado, os quais, por possuírem uma organização apical fechada, com iniciais funcionais em plena atividade, continuaram por um período complementar a crescer mesmo quando isolados da planta-mãe. Por outro lado, os explantes denominados de competentes corresponderiam àqueles cujos MARs já apresentavam o crescimento determinado estabelecido e, conseqüentemente, encontravam-se, em algum grau, no processo de modificações meristemáticas tanto morfológicas (mudança para MAR do tipo aberto) quanto fisiológicas que, em última instância, os habilitariam a desencadear sinais e/ou responder a esses no sentido de converterem-se em gemas caulinares.

Uma vez definido um estado de competência, uma sinalização endógena específica pode atuar com um gatilho desencadeador da conversão radicular em um meristema caulinar, com o conseqüente desenvolvimento de uma gema. Esse processo parece envolver passos múltiplos de elevada complexidade que variaram em velocidade e padrão de organização de acordo com o tratamento analisado. 
Estudos anteriores mostraram de maneira consistente o papel promotor das citocininas na conversão de ápices radiculares de C. fimbriatum em gemas caulinares (COLLI e KERBAUY, 1993; PERES e KERBAUY, 1999; SUZUKI al., 2004). Corroborando tais indícios, verificou-se nesse trabalho que a incubação de ápices radiculares isolados de plantas com 120 dias de idade na presença de uma citocinina exógena $(0,125 \mathrm{mg} / \mathrm{L}$ de benziladenina - BA) provocou uma maior velocidade e sincronia na conversão do MAR em gemas caulinares (Figura 22).

Observou-se que o tratamento com citocinina durante as primeiras 12 horas do isolamento não foi capaz de promover o aumento no número de gemas caulinares formadas a partir dos explantes radiculares (Figura 23). $\mathrm{Na}$ verdade, foi necessário que os explantes permanecessem na presença de BA por período igual ou superior a 24 horas para que houvesse um aumento significativo na formação de gemas caulinares, bem como para desencadear o evento na mesma intensidade que foi observada durante a incubação dos explantes na presença contínua da citocinina exógena (Figuras 23 e 22, respectivamente). Ainda que indiretamente, esses resultados indicam a importância da presença de concentrações elevadas de citocininas após cerca de 24 horas do isolamento dos explantes para o desencadeamento desse evento organogênico a partir de explantes competentes.

Além da confirmação da importância dessa classe hormonal para a evolução do processo organogênico em pauta, também pôde- se observar que o tipo de citocinina pareceu ser determinante no controle da aquisição de competência para a conversão do MAR em gemas caulinares. Verificou-se, por exemplo, que a aplicação de diferentes tipos de citocininas provocou diferentes respostas em explantes jovens, os quais foram isolados de plantas com 30 dias de idade. De maneira geral, tratamentos com citocininas do tipo zeatina (Z e ZR) resultaram em forte inibição do crescimento longitudinal dos explantes (Figura 19A e 20A) e, complementarmente, provocavam a aquisição de competência do MAR para conversão em gemas caulinares (com formação de gemas na região apical de boa parte dos 
explantes) (Figuras 19B e 20A). Por outro lado, a aplicação de citocininas do tipo iP (iP e iPR), embora ocasionassem uma certa inibição do crescimento longitudinal dos explantes (Figura 19A e 20A), não se mostrou suficiente para induzir o processo de conversão do MAR (Figura 19B e 20A).

Os tratamentos com citocininas do tipo $Z$ ocasionaram também a inibição do desenvolvimento do sistema radicular das plantas formadas tanto a partir da conversão do MAR de explantes jovens (Figura 20A) quando de explantes competentes, isolados de plantas com 120 dias de idade (Figura 20B). Por outro lado, o tratamento de explantes competentes com citocininas do tipo iP, embora não tenha afetado a sua conversão em gemas, ele estimulou o desenvolvimento radicular e inibiu o caulinar nas plantas formadas a partir da sua conversão (Figura 20B).

Esses resultados sugeriram que as citocininas do tipo $Z$ foram importantes para 0 favorecimento da perda das características radiculares típicas dos MARs jovens, devendo estar envolvidas com as modificações necessárias tanto para a aquisição de competência quanto para desencadeamento da conversão nesse tecido. Esse tipo de citocinina à medida que se mostrou inibitório à manutenção das características radiculares, também propiciou um efeito promotor do desenvolvimento da parte aérea de plantas de C. fimbriatum (Figura 20). Por outro lado, as citocininas do tipo iP foram relacionadas com a manutenção das características radiculares nos explantes jovens e ao estímulo da organogênese radicular em plantas formadas a partir da conversão do MAR competente (Figura 20).

Analisando-se o conteúdo de citocininas endógenas em ápices radiculares recémisolados de plantas com 30 e 120 dias de idade (explantes não-competentes e competentes para conversão em gemas, respectivamente), verificou-se que o tipo de citocininas iP preponderou sobre o tipo Z em ambos os explantes quando ligados à planta (Figura 17B). Esses resultados corroboram os dados obtidos com a aplicação de citocininas do tipo iP em explantes jovens, já que essas espécies de citocininas relacionam-se mais de perto à 
manutenção das características radiculares de C. fimbriatum, indicando um possível balanço entre os tipos de citocininas não favorável à conversão do MAR em gemas quando os ápices permanecem ligados à planta-mãe.

O envelhecimento radicular além de provocar um decréscimo nos teores de citocininas totais $(\mathrm{Z}+\mathrm{ZR}+\mathrm{iP}+\mathrm{iPR})$ (Figura $17 \mathrm{~A})$, ocasionou também mudanças na composição predominante entre os isômeros de ZR nos ápices radiculares, uma vez que explantes não competentes (isolados de plantas com 30 dias de idades) apresentaram uma predominância da forma cis-ZR, ao passo que nos ápices radiculares competentes (isolados de plantas com 240 dias de idade) predominou a forma trans-ZR (Figura 18). Esses resultados parecem indicar que no controle da aquisição de competência para a conversão do MAR em gemas caulinares possa estar envolvida uma regulação fina no metabolismo de citocininas, assim como é possível que a forma cis-ZR esteja mais relacionada ao crescimento radicular, e, conseqüentemente, com a própria manutenção do MAR.

O isolamento de explantes competentes (isolados de plantas com 120 dias de idade) ocasionou um decréscimo ainda maior e mais rápido no conteúdo de citocininas totais que perdurou durante as primeiras 12 horas do desligamento dos ápices radiculares da plantamãe (Figura 21A). Esse decréscimo foi observado tanto nas citocininas do tipo Z quanto iP; no entanto, essa queda foi mais expressiva nas citocininas do tipo iP, o qual era predominante nos ápices ligados à planta-mãe. Complementarmente, após as primeiras horas de isolamento verificou-se a tendência ao aumento nos teores endógenos das citocininas do tipo Z. Dessa forma, estabeleceu-se durante a maior parte do período que abrangeu o primeiro dia do isolamento dos explantes uma clara inversão no tipo de citocininas predominante, sendo aquelas do tipo Z presentes em maior proporção (Figura 21B).

Esse perfil traçado em relação à mudança do tipo de citocininas predominante nesses primeiros momentos do isolamento dos ápices radiculares teve forte correlação com as modificações histológicas observadas no MAR logo após o isolamento, o qual passou em 
apenas 12 horas da separação da planta-mãe de uma organização do tipo intermediáriaaberta para outra totalmente aberta (Figuras 15A e 15B). Esses resultados indicaram que o isolamento dos ápices radiculares de plantas de C. fimbriatum, quando comparado com o processo de envelhecimento radicular, intensificaria a competência para a conversão do MAR em gemas caulinares por meio de modificações estuturais mais rápidas, alavancadas no nível citocinínico por um decréscimo inicial mais rápido e proeminente no conteúdo destas substâncias, envolvendo presumivelmente, uma predominância inicial de citocininas do tipo Z.

Após 12 horas do isolamento dos explantes, verificou-se uma tendência de aumento nos teores endógenos de citocininas nos explantes, sendo que decorridos 48 horas do isolamento, a concentração de citocininas totais já tinha praticamente alcançado os valores encontrados nos explantes iniciais (Figura 21A). Nesse momento, ambos os tipos de citocininas encontravam-se presentes de maneira equivalente, devido principalmente ao aumento da participação das citocininas do tipo iP após cerca de 12 horas de isolamento (Figura 21B). Essa tendência poderia ter ocorrido como conseqüência de um provável aumento na biossíntese dessa classe hormonal a partir de iPR, considerada precursora na via biossintética das demais citocininas analisadas (AUER, 2002).

A ação promotora das citocininas sobre a evolução do processo de conversão do MAR em gemas caulinares ficou bem evidenciada à medida que se verificou a conversão de parte dos ápices radiculares ainda ligados a plantas com 240 dias, após transferidas para um meio de cultura novo suplementado com zeatina (Tabela 3 e Figura 24). Esses resultados indicaram que o deslocamento do balanço favoravelmente à Z poderia estimular a conversão de ápices radiculares em gemas, mesmo quando o MAR ainda permanecia sob o controle da parte aérea de plantas mais velhas.

O quadro acima exposto sugere que as citocininas poderiam atuar, em algum grau, tanto no ganho de competência por parte do meristema apical radicular, complementando-a, quanto no controle das divisões celulares que determinam, segundo KRAUS e MONTEIRO 
(1989), o início do processo de conversão dos ápices radiculares per se. De fato, já se conhece, de longa data, que as citocininas podem induzir a formação de meristemas caulinares a partir de células em proliferação desordenada, dando a indicação de que estes hormônios além de participarem dos eventos de indução e manutenção do ciclo celular (SKOOG e MILLER, 1957; del POZO et al., 2005), participariam também da organização estrutural e funcional do meristema apical caulinar (BONHOMME et al. 2000).

HEWELT e colaboradores (2000) verificaram que a regulação das citocininas no meristema apical caulinar de milho envolvia a participação do gene KNOTTED1 (KN1), um membro pertencente à família homeodomínio KNOX, o qual é homólogo ao KNAT1 e ao SHOOTMERISTEMLESS de $A$. thaliana. Há indícios de que a expressão de KN1 ocorre exclusivamente no meristema apical caulinar e possui envolvimento no desenvolvimento e manutenção desse tecido. A participação das citocininas durante este evento é algo passível de atenção, tendo em vista que essa classe hormonal é reconhecida por seu controle sobre a manutenção do ciclo celular e na expressão de fatores de transcrição, que assim como KN1, favorecem o estabelecimento e manutenção da organização meristemática caulinar (POZO et al., 2005).

Cabe ressaltar que, apesar da obtenção de bons indícios a respeito da atuação das citocininas durante o processo de aquisição e complementação de competência, bem como da conversão do MAR de $C$. fimbriatum em gemas caulinares, não se deve desconsiderar o envolvimento de outras moléculas sinalizadoras nesse processo, incluindo outros hormônios. Essas possibilidades foram consideradas a partir de resultados obtidos com a quantificação de citocininas em explantes submetidos a tratamentos com diferentes qualidades de luz que se mostraram promotoras (luz vermelha ou escuro) ou inibitórias (luz azul) à conversão do MAR competente (dados não apresentados). De acordo com estes resultados e dados da literatura a cerca dos efeitos da luz azul sobre os teores e/ou ação de outras classes hormonais, suscitou-se a possibilidade da participação de hormônios como as auxinas e 
giberelinas no processo, uma vez que se sabe que a luz azul (condição inibitória para conversão) diminuiria a sensibilidade e / ou os teores de auxina, bem como inibiria os genes de biossíntese de giberelinas, resultando na redução do alongamento celular e, conseqüentemente, do crescimento caulinar de plântulas de $A$. thaliana (FOLTA et al., 2003).

De fato, as giberelinas pareceram participar da aquisição de competência do MAR para conversão em gemas caulinares, uma vez que ápices radiculares isolados de plantas com 240 dias de idade apresentaram o conteúdo das giberelinas analisadas aumentado. Além disso, a quantificação dos teores endógenos das giberelinas $\mathrm{GA}_{1}$ e $\mathrm{GA}_{7}$ indicou que a predominância de tipos distintos de giberelinas no ápice radicular de $C$. fimbriatum poderia ter papéis diferenciados, uma vez que $\mathrm{GA}_{1}$ apresentou-se mais relacionado às fases onde 0 alongamento e a diferenciação celulares ocorreram durante as modificações profundas no MAR de plantas velhas, ao passo que $\mathrm{GA}_{7}$ pareceu estar mais relacionado aos eventos ocorridos nos ápices mais jovens (Figura 45B).

As auxinas também se reveleram um grupo hormonal com sinalização determinante para o controle do MAR de C. fimbriatum e de sua competência para conversão em gemas caulinares. Verificou-se que o envelhecimento radicular, com a concomitante aquisição de competência do MAR para conversão em gemas, coincidiu com uma diminuição substancial dos teores endógenos tanto de AIA livre quanto da sua forma conjugada AIA-Asp (Figura 25). Esse processo pode ter sido reflexo do fato de que, a partir de cerca de 100 dias de idade, as plantas de C. fimbriatum apresentam suas principais fontes de auxina prejudicadas, ou seja, a atividade do meristema apical caulinar encontra-se parada, sem formação de novas folhas, devido ao dreno representado pelo desenvolvimento do pseudobulbo (SUZUKI, 2005).

De acordo com essa linha de raciocínio, é razoável supor que o processo de diminuição do transporte polar de auxina já tenha início em plantas com idade ligeiramente inferior a 120 dias, uma vez que nesse momento boa parte das raízes das plantas já tinha 
atingido o estado de crescimento radicular determinando (Figura 3), bem como já haviam sido iniciadas as modificações estruturais no MAR (Figura 10C).

Baseando-se no conhecimento bem estabelecido de que os gradientes de auxina nas plantas dependem do controle de seu transporte polar, sendo ele responsável em última análise pela regulação de uma ampla variedade de processos de desenvovimento, incluindo a organogênese e manutenção do MAR (VIETEN et al., 2007), procurou-se estudar a importância deste transporte em plantas intactas de C. fimbriatum ainda jovens, visando mais particularmente o estudo do seu desenvolvimento radicular.

Dessa forma, verificou-se que aplicações de NPA (uma substância inibidora do transporte polar de auxina) em plantas intactas de C. fimbriatum a partir do $30^{\circ}$ dia de idade, resultaram em uma redução conspícua do crescimento da primeira raiz formada em cada planta (Figura 26). Além de provocar a redução do crescimento e desenvolvimento radicular (Figuras 26 e 27), estes tratamentos induziram, concomitantemente, e de maneira precoce, o estabelecimento do crescimento determinado das raízes (Figura 26).

Tais tratamentos também foram capazes de desencadear modificações morfológicas na região apical das raízes, as quais eram visíveis a olho nu, especialmente nos ápices

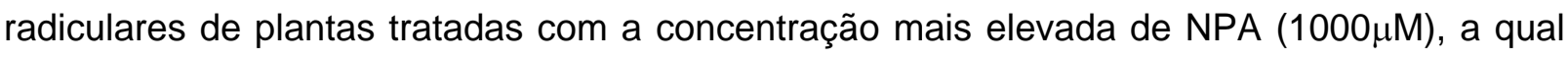
provocou o intumescimento da região meristemática das raízes (Figura 27), de maneira muito semelhante às modificações observadas no início do processo de conversão desencadeado pelo isolamento dos ápices radiculares competentes (Figura 14A).

As análises histológicas dos ápices radiculares tratados com NPA, por sua vez, revelaram que o bloqueio do transporte polar de auxina nesse tecido levava a uma intensa diferenciação dos tecidos apicais da raiz, a parada da atividade do MAR e subseqüente diferenciação da maioria das células meristemáticas em células parenquimáticas (Figura 28). De certa forma, esses resultados apresentam certa relação com os eventos observados nos ápices radiculares de plantas com 240 dias, cujos MARs também se diferenciaram 
parcialmente em células parenquimáticas e os respectivos CQs tornavam-se altamente modificados devido a uma aparente perda de quiescência das suas células (Figura 10D). KERK e FELDMAN (1995), estudando os efeitos da aplicação de NPA em raízes de milho, observaram um aumento na atividade mitótica do CQ. Mais recentemente, JIANG et al., (2003) complementaram esses resultados através da observação de que a auxina promovia a ativação do CQ em sua face distal, ocasionando a mudança da organização fechada do MAR para aberta.

Dessa forma, verificou-se que condições responsáveis por um distúrbio mais severo na homeostase do transporte polar de auxina na região do MAR parecem levar os ápices radiculares de $C$. fimbriatum, mesmo que jovens e ainda sem a necessária competência para a conversão, a uma profunda reorganização meristemática, cujas características estruturais comparam-se aos meristemas com competência para conversão em gemas caulinares. No entanto, nesse caso o processo pode não ter se completado devido a uma condição fisiológica desfavorável ao aumento nos teores de citocininas endógenas, enquanto os ápices radiculares foram mantidos ligados a planta-mãe e sob incubação na presença do inibidor de transporte polar de auxina. De fato, quando os teores endógenos de citocininas foram analisados nos ápices radiculares de plantas jovens de $C$. fimbriatum que permaneceram em incubação na presença de NPA, verificou-se que a concentração endógena de citocininas não foi alterada significativamente por esse tratamento em comparação à condição controle (Figura 29).

Ainda dentro dessa hipótese, é plausível supor que o isolamento do ápice radicular de C. fimbriatum provoque, entre outras conseqüências como é o caso do acúmulo de citocininas em longo prazo (PERES e KERBAUY, 1999), uma diminuição intensa da chegada de auxina no tecido meristemático devido à interrupção do seu transporte polar. Da mesma maneira, esse processo parece ocorrer, de forma mais lenta, durante o desenvolvimento das plantas 
de $C$. fimbriatum, sendo que a chegada da auxina até os ápices radiculares parece diminuir, gradativamente, ao longo do desenvolvimento das plantas.

A incubação de ápices radiculares isolados de plantas jovens com NPA, por sua vez, desencadeou, assim como verificado nas plantas intactas tratadas com essa substância, uma severa inibição do crescimento longitudinal dos explantes, acompanhada de modificações estruturais apicais consideráveis (Figura 30 e 31, respectivamente). Ainda de acordo com o observado nas plantas intactas, a aplicação da maior concentração de NPA empregada $(1000 \mu \mathrm{M})$ desencadeou o intumescimento do MAR, sendo que sob esta condição experimental parece ter ocorrido a aquisição de competência para sua conversão em gema caulinar, uma vez que essa estrutura era capaz de originar uma nova planta, após a retirada dos explantes da presença de NPA (Tabela 4).

Esses resultados parecem enfatizar que perturbações do transporte polar de auxina podem ter atuado, de maneira substancial na aquisição de competência para conversão do MAR; no entanto, conforme já aventado, outros sinais desencadeados pelo isolamento dos explantes (tais como o acúmulo de citocininas) pareceram essenciais para que esse processo organogênico se consolide, uma vez que não foi observada a formação de nenhuma gema caulinar a partir do MAR intumescido de plantas intactas de $C$. fimbriatum tratadas com $1000 \mu \mathrm{M}$ de NPA (Figura 27). Dessa forma, os resultados obtidos no presente trabalho mostram que distúrbios no transporte polar de auxina, desencadeados, por exemplo, pela aplicação de NPA em ápices radiculares jovens (isolados ou ligados a planta-mãe), foram capazes de provocar, de maneira equivalente, porém mais intensa ao que foi observado durante o envelhecimento dos ápices radiculares de C. fimbriatum, ou seja, uma inibição conspícua do crescimento longitudinal radicular orquestrada por modificações estruturais profundas que levaram à repressão da atividade do MAR.

Além disso, a observação da perda da coifa durante o período anterior às etapas que desencadearam a reorganização do MAR e sua conversão em gema caulinar (Figuras 5, 9, 
10 e 15), de certa forma corroborou a ocorrência de possíveis distúrbios na distribuição e/ou concentração de auxina na região apical de raízes de $C$. fimbriatum. De fato, verificou-se que um membro da família de transportadores de auxina, a proteína AtPIN4, estaria ligado ao estabelecimento de um dreno de auxina na região das iniciais da coifa, sendo que sua função parece ser essencial para a distribuição de auxina na raiz (FRIML et al., 2002). Ainda de acordo com essa possibilidade, JIANG et al., (2003) sugeriram que a perturbação no transporte polar de auxina poderia modificar a manutenção do balanço entre as células do CQ e da coifa, provocando a mudança do MAR do tipo fechado para aberto.

Estudos têm mostrado, consistentemente, que perturbações na distribuição ou na concentração de auxina em raízes podem ocasionar mudanças metabólicas nas células do $\mathrm{CQ}$, podendo levar a perda de sua quiescência e culminar em divisões celulares incomuns nessa região (KERK e FELDMAN, 1995; KERK et al., 2000; JIANG et al., 2003). Paralelamente, KRAUS e MONTEIRO (1989) mostraram, por meio de análises histológicas, que o processo de formação das gemas caulinares em ápices radiculares isolados de $C$. pileatum teve início com o aumento de divisões celulares na região do CQ.

SABATINI et al. (1999) verificaram a importância do transporte polar de auxina no estabelecimento de uma concentração máxima de auxina na região do MAR, a qual engloba o CQ. Em consonância com esse relato, estudos têm agregado informações acerca da importância do transporte polar de auxina para a manutenção do CQ e, conseqüentemente, para organização do MAR (KERK e FELDMAN, 1995; KERK et al., 2000; JIANG e FELDMAN, 2003). Atualmente, sabe-se que na região onde ocorre o máximo de auxina, também se dá a expressão do gene PLETHORA, a qual é dependente de auxina, e que participa junto a ela na conservação das características fundamentais do MAR, incluindo a manutenção do funcionamento do CQ (AIDA et al., 2004)

De fato, a rede de comunicação entre as células do CQ, da coifa e do meristema fundamental é normalmente realizada por meio do trânsito celular de fatores de transcrição 
determinantes na especificação, organização e funcionamento de cada região do MAR (VEIT, 2006). Baseando-se na literatura recente, é plausível sugerir que em C. fimbriatum ocorram distúrbios no trânsito de certos fatores de transcrição (tais como homólogos de PLETHORA, SCARECROW, SHORT ROOT, entre outros) durante o ganho de competência e conversão do MAR em gemas caulinares. Dessa forma, a aquisição de competência para o estabelecimento de um meristema caulinar a partir de células radiculares de C. fimbriatum, prescindiria de mudanças na expressão de um ou mais fatores que confere $(m)$ as características celulares intrínsecas de MAR, possibilitando as células que o compõe responder a diferentes sinais e, conseqüentemente, a adquirir rotas distintas de diferenciação e desenvolvimento.

Os dados obtidos acerca do controle hormonal na organização e atividade do MAR de C. fimbriatum respaldam a hipótese de que as diferenças observadas na competência e morfologia externa relacionadas à conversão de ápices radiculares com diferentes idades (Figura 4) poderiam ser reflexos, entre outros fatores, de uma mudança na regulação exercida pela auxina sobre a organização e atividade do MAR. Corroborando esse importante papel estabelecido para as auxinas no controle da organização e atividade do MAR (JIANG e FELDMAN, 2005), bem como os indícios anteriores de que essa classe hormonal provocaria um efeito antagônico ao processo de conversão do MAR de $C$. frimbriatum em gemas caulinares (COLLI e KERBAUY, 1993; PERES et al., 1999), no presente trabalho, verificou-se que a incubação de ápices radiculares jovens na presença de AIA promoveu a manutenção do crescimento longitudinal das raízes dessa orquídea quando isoladas da planta-mãe (Figura 32).

Complementarmente, verificou-se que o MAR de C. fimbriatum com 240 dias de idade respondeu diferentemente a sinais hormonais distintos, seja para a retomada da organogênese radicular (com a adição de auxina), ou para a conversão em gemas (com a adição de citocininas), indicando que os MARs das diferentes raízes analisadas pareceram ter 
competência para organogênese diferenciada. Essa tendência ficou ainda mais clara com a observação de que parte dos ápices radiculares de plantas velhas tratadas simultaneamente com Z e AIA retomou o crescimento radicular, sendo que outra parte se converteu em gemas, e ainda um terceiro conjunto não respondeu ao tratamento (Figura 33 e Tabela 5).

Com base nessas informações, supõe-se que em $C$. fimbriatum haja um grau de envelhecimento diferenciado entre as raízes adventíceas formadas, sendo que a idade acarretaria em um estágio de desenvolvimento radicular específico, o qual poderia ou não apresentar as modificações necessárias para o ganho de competência do MAR para responder a diferentes sinalizações hormonais e, conseqüentemente, para seguir um caminho específico do desenvolvimento.

O envelhecimento também acarretou um aumento na produção de etileno pelas plantas de C. fimbriatum com 240 dias de idade (Figura 34), coincidindo no caso com a presença nessas plantas de boa parte das folhas em processo de senescência, pseudobulbo proeminente, o qual refletiria segundo SUZUKI (2005), um meristema apical caulinar sem atividade e sem formação de folhas novas. O etileno representa o fitormônio mais freqüentemente relacionado a respostas de envelhecimento em tecidos vegetais (van LOON e GLICK, 2004), bem como vem sendo apontado como importante regulador de respostas dadas pelo transporte polar de auxina em meristemas radiculares (CASSON e LINDSEY, 2003).

Em vista da correlação detectada entre as constatações acima expostas e a observação de que o processo de aquisição de competência para conversão do MAR de $C$. fimbriatum foi dependente do envelhecimento radicular (Figura 4), procurou-se analisar o comportamento de raízes ligadas a plantas ainda jovens, as quais foram tratadas com concentrações relativamente elevadas de etileno durante 0 período inicial do desenvolvimento. 
Dessa forma, constatou-se que a exposição de plantas jovens de C. fimbriatum a concentrações elevadas de etileno inibiu o crescimento radicular, desencadeando o estabelecimento precoce do crescimento determinado das raízes (Figuras 35 e 37). Tratamentos com 1-MCP, uma substância inibidora de receptores de etileno, favoreceram, por sua vez, o crescimento inicial da primeira raiz de cada planta durante as duas primeiras semanas de tratamento (Figura 36); no entanto, não afetou o tamanho final das mesmas. Esses resultados indicaram que a presença (e percepção) de etileno em concentrações elevadas foi prejudicial ao crescimento radicular de plantas jovens de $C$. fimbriatum.

A administração de etileno durante os estágios iniciais de desenvolvimento de plantas de C. fimbriatum cultivadas in vitro ocasionou, assim como observado nos tratamentos de plantas de mesma idade com NPA, fortes alterações na organização histológica do MAR. Análises histológicas dessa região em plantas jovens submetidas a um período crescente de exposição à $500 \mu \mathrm{M}$ de etileno mostraram que esse tratamento afetava negativamente o crescimento radicular, simultaneamente a uma forte indução de diferenciação de todos os tecidos do ápice radicular, incluindo a região do próprio MAR (Figura 38).

Com o aumento do tempo de exposição ao etileno, pode-se notar a ocorrência de alterações celulares dentro do MAR muito semelhantes àquelas encontradas no meristema radicular de plantas submetidas ao tratamento com $1000 \mu \mathrm{M}$ de NPA (Figuras 38E e 28G, respectivamente). Dentre essas alterações, destacou-se a modificação na organização celular do CQ, com a presença de um novo grupo de células nessa região (Figuras 38E). No entanto, de maneira distinta ao que foi visto no MAR tratado com NPA, a região equivalente das raízes tratadas com etileno foi ocupada por um novo conjunto de células aparentemente derivado da perda de quiescência do CQ, o qual era constituído por células envolvidas em processo mitótico. Essas divisões celulares mostraram-se relacionadas com a consolidação e estabelecimento da gema caulinar no MAR alterado, a partir da qual se desenvolveu uma nova planta (Figura 38G). Essa seqüência de alterações morfológicas desencadeadas pelo 
etileno corroborou as indicações anteriores de que as modificações do MAR que levam ao seu intumescimento estão fortemente relacionadas e, possivelmente sejam necessárias para a aquisição de competência dos ápices radiculares e sua conversão em gemas caulinares em C. fimbriatum.

Os resultados obtidos no presente estudo dão respaldo aos indícios anteriormente obtidos por KERBAUY e COLLI (1997), os quais verificaram que a aplicação de substâncias liberadoras de etileno, como ácido 2-cloroetilfosfônico (CEPA), ou de seu precursor bioquímico como o ácido carboxílico aminociclopropano (ACC), estimulavam a conversão de ápices radiculares isolados de plantas de C. fimbriatum. Esses autores sugeriram que o efeito promotor do etileno sobre esse evento poderia ser reflexo de uma redução nos teores endógenos de AIA nos explantes e de um aumento concomitante na concentração de citocininas endógenas. Tal sugestão foi respaldada mais adiante pelos resultados obtidos por PERES et al. (1999), com a quantificação dos teores endógenos dessas classes hormonais em explantes também isolados de C. fimbriatum.

Os resultdos ora obtidos corroboraram as evidências anteriores obtidas, uma vez que os ápices radiculares das plantas tratadas com etileno apresentaram no momento que antecedeu o estabelecimento do meristema caulinar uma elevação considerável nos teores de citocininas endógenas. Nesse caso, observou-se que o tipo de citocinina predominante após o tratamento com etileno passou a ser do tipo $Z(Z+Z R)$, assim como observado nas primeiras horas após o isolamento de ápices radiculares competentes para conversão em gemas caulinares (Figura 21B). Complementarmente, verificou-se que, como observado em ápices radiculares recém-isolados de plantas com 240 dias de idade, após o tratamento com etileno ocorreu a predominância do tipo trans-ZR no MAR de plantas jovens (Figura 43).

O tratamento de plantas jovens e intactas de C. fimbriatum com etileno também proporcionou uma série de modificações no desenvolvimento do sistema radicular como um todo. Verificou-se, por exemplo, um aumento na massa fresca radicular causado pelo 
estímulo na formação de novas raízes adventícias, as quais tiveram parte de seus MARs convertidos em gemas caulinares (Figura 40). O etileno também ocasionou a indução da diferenciação de células especializadas como pêlos absorventes, velame e células com espessamento pariental secudário (Figura 41). Tais células com espessamento pariental secudário foram identificadas por outros autores em raízes de C. fimbriatum (OLIVEIRA e SAJO, 1999), sendo que, segundo KOLLER e ROST (1988), a função dessas células estaria relacionada à retenção de água e ao suporte mecânico, evitando o colapso celular durante a dessecação.

De fato, teores elevados de etileno normalmente levam à formação de um maior número de raízes adventícias, no entanto, estas normalmente apresentam tamanho reduzido (RIOV e YANG, 1989). Estudos têm sustentado a ação promotora do etileno na rizogênese adventícia, como é o caso das plantas mutantes de tomateiro denominadas never ripe, as quais são deficientes para a síntese de etileno e, quando comparadas às plantas selvagens, apresentam uma diminuição acentuada na capacidade de formação de raízes adventícias; no entanto, quando esse material foi tratado com ACC, a rizogênese adventícia ocorreu normalmente, demonstrando a importância do etileno nesse evento organogênico (BLEECKER et al., 1988; LANAHAN et al., 1994; CLARK et al., 1999). A diminuição na capacidade de formação de raízes adventícias também foi observada em estacas de Petunia sp. mutante para uma menor sensibilidade ao etileno (CLARK et al., 1999).

Apesar do papel do etileno na rizogênese já ser conhecido há bastante tempo (ZIMMERMAN e HITCHCOCK, 1933), os estudos dos componentes moleculares que atuam nas respostas a esse fitormômio na regulação do desenvolvimento radicular só foram iniciados mais recentemente; vários desses trabalhos sugerem que a sinalização pelo etileno envolveria uma interação simultânea com a auxina, levando a respostas regulatórias no ápice radicular (PONCE et al., 2005; STEPANOVA et al., 2005; PRAYITNO et al., 2006). 
Dessa forma, é plausível supor que o etileno tenha agido como elemento promotor da conversão do MAR jovem de C. fimbriatum em gemas caulinares por meio da inibição, pelo menos parcial, do transporte polar de auxina. Essa hipótese conta com o suporte de alguns dados, tais como: a semelhança dos efeitos provocados pelo etileno e pelo NPA sobre a aquisição de competência do MAR de C. fimbriatum para conversão em gemas, o fato do etileno ter inibido consideravelmente o desenvolvimento da parte aérea de $C$. fimbriatum (importante fonte de produção de auxina), assim como o conhecimento baseado na literatura do etileno poder agir como um importante fator inibitório do transporte polar de auxina em muitas espécies vegetais (ABELES et al., 1992).

Ainda dentro dessa hipótese, como anteriormente proposto, é razoável supor que durante o envelhecimento das plantas de C. fimbriatum haja uma diminuição gradual no transporte polar de auxina, uma vez que as principais fontes de auxina para as raízes estariam prejudicadas (atividade do meristema apical caulinar parada, sem formação de novas folhas), e esse evento poderia ser agravado em idades mais avançadas (por volta de 240 dias), quando foi verificado o aumento da concentração de etileno emitido pelas plantas no interior dos frascos (Figura 34).

De fato, o etileno é considerado um importante regulador natural do crescimento radicular, sendo que os teores emitidos desse gás sob condições naturais são geralmente baixos, no entanto, quando as raízes encontram-se sob condições de estresse, a concentração emitida desse hormônio tende a aumentar drasticamente, levando a mudanças profundas no desenvolvimento radicular (FELDMAN, 1984). Essas informações agregam elementos que indicam que plantas de C. fimbriatum, confinadas por 240 dias em recipientes com trocas gasosas prejudicadas, e em meio de cultura com as características apresentadas na figura 7, devem se encontrar sob condições de estresse. Dessa forma, supõe-se que condições de estresse poderiam participar do estabelecimento da competência do MAR para a sua conversão em gemas. 
De acordo com essa linha de raciocínio, verificou-se que os teores endógenos de ácido abscísico ( $\mathrm{ABA}$ ) encontraram-se comparativamente elevados nos ápices radiculares recém-isolados de plantas com 240 dias de idade (Figura 45A). Sabe-se que o ABA, assim como o etileno, representam classes hormonais envolvidas freqüentemente com eventos de sinalização em respostas ao estresse (FINKELSTEIN et al., 2002).

Segundo IVANOV (2007), o estresse oxidativo influencia amplamente o desenvolvimento do MAR dos vegetais em geral. Está bem estabelecido que a regulação da divisão celular no MAR é dependente do estado redox no citossol (KERK e FELDMAN, 1995; KERK et al., 2000; JIANG e FELDMAN, 2003), sendo que as regiões do MAR com baixas taxas de divisões celulares, como é o caso do CQ, apresentam predomínio das formas oxidadas de ascorbato e glutationa, ao passo que nas regiões com atividade mitótica mais elevada os teores das formas reduzidas se apresentam relativamente mais altos (KERK e FELDMAN, 1995).

Com o objetivo de se adquirir maiores imformações a cerca do potencial mitótico de ápices radiculares de C. fimbriatum durante o processo de aquisição de competência, realizou-se a quantificação das formas reduzidas de glutationa (GSH) e ascorbato (ASC) nos ápices radiculares de C. fimbriatum durante o envelhecimento radicular. Essas análises revelaram que a presença desses compostos diminuiu a partir do $60^{\circ}$ dia de vida das plantas (Figura 46). Uma vez que esses compostos são relacionados com a estimulação de divisões celulares no MAR (KERK e FELDMAN, 1995), esses dados são coerentes com as informações obtidas de que, a partir do $60^{\circ}$ dia de idade, as plantas de C. fimbriatum já apresentaram suas primeiras raízes com redução no crescimento.

O isolamento de ápices radiculares jovens, portanto não competentes para conversão do MAR em gemas caulinares, induziu uma diminuição nos teores endógenos de ASC após o primeiro dia do isolamento. No entanto, essa tendência não foi observada nos teores de GSH, 
os quais, de maneira contrária, aumentaram no primeiro dia do isolamento dos explantes, mantendo-se após esse período com valores próximos ao encontrado na condição inicial (Figura 49). Esses dados apontam para uma possível situação em que a manutenção da atividade do MAR nos explantes jovens possa ser mantida pela presença de GSH em concentrações favoráveis à organização e atividade do MAR de C. fimbriatum.

De fato, sabe-se que GSH além de desempenhar papel no controle das divisões celulares, também participa como importante sinal para a manutenção da organização e atividade do MAR. Plantas mutantes de $A$. thaliana para o gene ROOT MERISTEMLESS, que codifica a primeira enzima da biossíntese de GSH, não possuíam o MAR nos estágios pósembrionários devido à ocorrência de desorganização em sua estrutura, o que impossibilitava a formação de novas células iniciais funcionais. No entanto, esse atributo estrutural dos mutantes foi revertido por meio do tratamento destas plântulas mutantes com GSH (VERNOUX et al., 2000). Complementarmente, foi verificado em cultura de células de alfafa incubadas na presença de um inibidor específico da primeira enzima da biossíntese de GSH também induzia a inibição do ciclo celular (POTTERS et al. 2004, SÁNCHEZ-FERNÁNDEZ et al.; 1997).

Po outro lado, o isolamento de ápices radiculares competentes (a partir de plantas de C. fimbriatum com 120 dias de idade) ocasionou, de maneira inversa ao observado nos explantes não-competentes, um aumento significativo de ASC e, adicionalmente, não foram observadas mudanças na concentração de GSH (Figura 49). Esses dados indicam que o isolamento de explantes competentes envolva uma situação fisiológica que propicie a retomada de divisão celular no MAR competente, uma vez que a presença de teores elevados de ASC nos meristemas é fortemente relacionada com regiões em elevada atividade mitótica (KERK e FELDMAN, 1995).

Dessa forma, pode-se supor que o aumento de ASC nos ápices radiculares competentes de C. fimbriatum possa estar relacionado com a perda da quiescência das 
células do CQ durante o processo de reorganização do MAR para o estabelecimento do meristema caulinar após o isolamento. Diversos estudos dão suporte ao papel de GSH e ASC na atividade do CQ. Segundo VERNOUX et al., 2000; JIANG et al., 2003; del POZO, 2005), GSH estaria relacionada com a transição da fase G1 para S do ciclo celular, enquanto ASC encontra-se predominantemente presente em regiões radiculares com elevada taxa de proliferação celular (KERK et al., 2000). Ainda dentro dessa idéia, segundo KERK e FELDMAN (1995), o caráter quiescente das células do MAR seria mantido pela interação de concentrações mais elevadas de auxina e a presença predominante das formas oxidadas de glutationa e ascorbato, via atividade da ácido ascóbico oxidase.

Explantes radiculares jovens de C.fimbriatum tratados com GSH apresentaram uma relação dose-resposta positiva em relação ao crescimento longitudinal dos explantes, dando forte respaldo às indicações da importância da forma reduzida de glutationa para a manutenção da atividade do MAR também em plantas de C. fimbriatum. Por outro lado, verificou-se que tratamentos de ápices radiculares jovens com substâncias promotoras de estresse oxidativo, como a menadiona e o paraquat (ambos indutores da formação de superóxidos nos tecidos), ocasionavam respostas fortemente inibitórias ao crescimento das raízes e à atividade do MAR nessa espécie (Figura 47). Neste caso, tomando-se em conta os resultados observados sobre a importância da natureza aberta ou fechada dos meristemas radiculares, e seus efeitos sobre o crescimento destes órgãos em geral, não se descarta a possibilidade de que a inibição do crescimento radicular observada em C. fimbriatum sob essas condições, reflita uma desorganização meristemática provocada pela modificação do MAR do tipo fechado para o tipo aberto.

Tal proposta baseia-se no fato de que os explantes radiculares tratados com $1 \mu \mathrm{M}$ de paraquat não se converteram em gemas caulinares, no entanto, quando os mesmos foram transferidos deste tratamento para meio de cultura desprovido dessa substância, verificou-se a formação de gemas a partir do MAR alterado, indicando que esse herbicida foi capaz de 
provocar a parada da atividade do MAR e o ganho de competência para conversão desse tecido em gemas caulinares (Figura 48). No entanto, tanto o tratamento contínuo com paraquat quanto com menadiona mostrou-se inibitórios à formação da gema caulinar, provavelmente pela formação de espécies reativas de oxigênio, as quais poderiam afetar negativamente as divisões celulares no MAR e sua re-organização para o estabelecimento do meristema caulinar.

O óxico nítrico (NO) é um radical livre, cuja participação como mensageiro secundário foi constatada em diferentes processos de sinalização em plantas, incluindo respostas relacionadas à organogênese radicular (PAGNUSSAT et al., 2002, 2003; GUO et al., 2003; CORREA-ARAGUNDE et al., 2004). No presente trabalho verificou-se que a redução do NO nos ápices radiculares jovens de C. fimbriatum, por meio do tratamento com CPTIO (uma substância eliminadora de NO), desencadeou uma drástica inibição no crescimento longitudinal dos explantes, ao passo que a aplicação de SNP (uma substância doadora de NO) potencializou a atividade do MAR quando administrada em concentrações moderadas, estimulando o crescimento longitudinal dos ápices radiculares isolados de plantas jovens. No entanto, concentrações elevadas dessa substância (por volta de $100 \mu \mathrm{M}$ ), mostraram-se fortemente inibitórias ao crescimento deste órgão, induzindo o intumescimento da região apical dos explantes (Figura 50 e Tabela 7). Indícios complementares acerca da participação do NO na organização e atividade do MAR dessa orquídea foram obtidos por meio da utilização de uma substância marcadora de NO por fluorescência em tecidos (DAF-2DA). Tomando-se a maior presença interna e localizada do NO como indicativo de sua maior atividade, poder-se-ia inferir que este radical livre estaria de alguma maneira envolvido tanto no ganho de competência do MAR quanto no próprio desenvolvimento do primórdio da gema gerada nesse evento organogenético (Figuras 51 e 52, respectivamente).

Nesse sentido, verificou-se uma intensa presença do NO no MAR de raízes de plantas com 240 dias de idade, especialmente nas regiões equivalentes ao cilindro vascular e ao 
centro da região meristemática onde foi encontrado o grupo de células aparentemente derivado da perda de quiescência do CQ, cujas características verificadas anteriormente indicaram estar envolvidas em processo de diferenciação de células vasculares (Figura 8L). O NO e a auxina têm sido fortemente apontados como importantes sinalizadores dos estágios iniciais da diferenciação de células vasculares (GABALDON et al., 2005), sendo que distúrbios na concentração de ambos sinais parecem desencadear o avanço no processo de diferenciação dos tecidos, incluindo os vasculares, no caso do MAR de C. fimbriatum.

Frente ao acima exposto, sugere-se que o NO, de alguma forma contribua na regulação do desenvolvimento dos ápices radiculares de C. fimbriatum de maneira dependente da concentração; em teores menores estimularia e manteria as características juvenis das raízes de $C$. fimbriatum, enquanto em concentrações mais elevadas influenciaria positivamente a aquisição de competência para a conversão dos MARs. É possível que estes efeitos do NO sejam estabelecidos por meio da regulação da sinalização induzida pela auxina. No entanto, diante ainda da falta de melhores elementos de convicção a respeito, não se pode descartar a possibilidade de que esses sinais ajam por meio de rotas separadas e complementares. De acordo com esse raciocínio, é sabido, por exemplo, que o NO pode atuar como um importante mensageiro secundário nas respostas de organogênese radicular desencadeadas por auxina em diferentes espécies vegetais (PAGNUSSAT et al., 2002, 2003; GUO et al., 2003; CORREA-ARAGUNDE et al., 2004).

O cálcio citossólico é um dos mensageiros secundários mais freqüentemente relacionados a respostas celulares envolvidas com o controle da atividade meristemática (WHITE e BROADLEY, 2003). Em ápices radiculares de plantas de C. fimbriatum constatouse que as variações detectadas em suas concentrações apresentavam fortes correlações como a cessação da atividade do MAR, ganho de competência e indução da conversão desse tecido em gemas caulinares. De maneira semelhante ao observado com o NO, a análise da distribuição do cálcio citossólico por meio da marcação por fluorescência, mostrou sua 
presença maciça em ápices radiculares de plantas de C. fimbriatum com 240 dias de idade. Sua localização predominante também coincidiu com as regiões correspondentes ao cilindro vascular e a região meristemática central, de onde é originado o grupo de células aparentemente derivado da perda de quiescência do CQ (Figura 55H).

A utilização de uma substância quelante de cálcio citossólico (EGTA), e de uma outra estimuladora da sinalização dada por esse íon (ionomicina, um ionóforo de cálcio), provocaram a parada da atividade do MAR de C. fimbriatum, desencadeando a formação de uma estrutura intumescida na região apical dos explantes. No entanto, essas estruturas apenas evoluíram para a conversão do MAR quando na presença de concentrações relativamente elevadas de cálcio citossólico, estas decorrentes da aplicação de ionomicina.

A importância do cálcio citossólico no ganho de competência nesse evento organogênico é corroborada por estudos das fases iniciais da embriogênese somática em algumas espécies. Nestes estágios, as células envolvidas na formação dos embriões apresentavam concentrações de cálcio mais elevadas no citossol de maneira prolongada, condição esta na qual seria promovido o fechamento dos plasmodesmas, estabelecendo-se o isolamento simplástico dessas células (KAMINEL, 1992; TIMMERS et al., 1996).

Dessa forma, um incremento mais demorado na concentração de cálcio citossólico, obtido pelo emprego de ionomicina em ápices radiculares jovens de $C$. fimbriatum ou pelo envelhecimento dos mesmos ligados à planta-mãe, poderia resultar no isolamento simplástico das células do MAR, sendo que esse evento poderia ser um dos responsáveis pelas mudanças estruturais observadas nesse tecido após a parada do crescimento radicular. Essa hipótese respalda-se no fato de que o MAR de raízes da maioria das espécies ao atingir o crescimento determinado, adquire uma organização do tipo aberta, cujas células freqüentemente apresentam uma diminuição no número de plasmodesmas, provocando, dessa forma, o seu isolamento simplástico do restante dos tecidos radiculares (VERNOUX et al. 2000). 
Baseando-se nos eventos observados nos MARs de C. fimbriatum áptos à conversão, que apresentam uma organização do tipo aberta, a qual, aparentemente, os possibilita evoluir para o intumescimento apical, sugere-se que o isolamento simplástico possa ocorrer de maneira a possibilitar condições propícias ao estabelecimento de um novo grupo de células meristemáticas que seria, em última análise, precursoras da organização do meristema apical caulinar. Essas células poderiam ser representadas por aquelas aparentemente derivadas da perda da quiescência do CQ observada no processo de alterações morfológicas no MAR durante a complementação de sua competência para conversão em gemas.

Há indícios da participação das citocininas na estimulação de altos e demorados teores de cálcio citossólico, que antecedem o início da especificação de um nicho de células que se diferenciariam em um embrião somático (KAMINEK, 1992; TIMMERS et al., 1996). Além disto, este tipo de fitormônio exerce também um forte efeito estimulatório no processo de diferenciação de gemas caulinares a partir do MAR de C. fimbriatum, conforme é dado concluir com base nos trabalhos de COLLI e KERBAUY (1993); PERES e KERBAUY (1999) e PERES et al. (1999). Nesse caso, não se descarta a possibilidade de que as citocininas e / distúrbios no transporte polar de auxina estejam relacionados no controle dos teores de cálcio citoplasmático nas células do MAR envolvidas na formação da gema caulinar.

Quanto à estrutura de formato globular formada a partir da incubação de explantes jovens na presença de EGTA, a qual não se evoluiu para a formação subseqüente de gemas caulinares, poderia tentativamente ser atribuído a uma quantidade insuficiente desse íon no tecido para vários processos celulares envolvidos na organogênese nos quais a participação do cálcio parece vital, inclusive divisões e polaridade celulares. Também se supõe que a insuficiência de cálcio nessa condição experimental, possa ter ocasionado uma situação em que não foi possível a manutenção da organização e funcionamento normais do MAR de explantes jovens de $C$. fimbriatum para o crescimento radicular. 
Dessa forma, os resultados obtidos tanto com o aumento quanto com a diminuição de cálcio citossólico nas células, assim como a visualização da distribuição desse íon no MAR deixaram claramente explícita a importância de um controle fino do cálcio no meristema de $C$. fimbriatum. De fato, esse tecido apresentou especializações que poderiam estar envolvidas na regulação da disponibilidade desse íon nas células meristemáticas de uma maneira muito peculiar. Verificou-se que na região apical das raízes de C. fimbriatum, principalmente quando jovem, encontrou-se um grande número de idioblastos, células estas armazenadoras de cristais de oxalato de cálcio nos vacúolos na forma de ráfides. Essas células despertaram a atenção pelo posicionamento bem definido, bem como pela precocidade com que se formaram no interior do ápice radicular. A formação destas células poderia estar relacionada ao fato de que células ainda jovens e com atividade mitótica muito acentuada, como é o caso das células encontradas no meristema fundamental e região de alongamento de ápices radiculares de $C$. fimbriatum com 30 dias, possuem vacúolos muito pequenos, aparentemente com capacidade reduzida de controlar os teores de cálcio por seqüestro intracelular.

Estudos mostram que o acúmulo de cálcio no apoplasto de tecidos contendo células jovens e em processo de desenvolvimento pode interferir no processo de expansão celular. Dessa maneira, a formação de idioblastos com cristais de oxalato de cálcio parece atuar como um dreno específico e localizado de cálcio durante o desenvolvimento dos tecidos, reduzindo a concentração desse íon no apoplasto ao redor das células em crescimento, e possibilitando-as a se desenvolverem normalmente (FRANCESCHI e NAKATA, 2005). Evidências adicionais para a regulação do cálcio por meio da formação desse tipo de idioblastos têm sido relatadas pelo desaparecimento de tais cristais sob condições de deficiência de cálcio (VOLK, 2002), maturação durante o desenvolvimento (ILARSLAN et al., 1997; 2001; STOREY et al., 2003), e quando o crescimento é bastante ativo e a disponibilidade de cálcio é limitada (FRANCESCHI e NAKATA, 2005). 


\section{CONCLUSÕES}

Diferentemente do que se imaginou durante um bom tempo, os resultados obtidos nesse estudo mostraram que a competência para conversão do meristema apical radicular (MAR) de Catasetum fimbriatum em gemas foi dependente da idade das raízes.

Comprovou-se a aquisição de competência para conversão do MAR dessa orquídea encontrou-se intimamente ligada ao estabelecimento do crescimento radicular determinado das raízes e à ocorrência de modificações morfológicas e fisiológicas no MAR durante o envelhecimento. A separação dos ápices radiculares da planta-mãe pareceu desencadear, de maneira mais rápida, os eventos que ocorreram no MAR de raízes ligadas às plantas velhas, onde foi marcante a desorganização meristemática, seguindo-se da diferenciação de parte boa das células do meristema fundamental.

Baseando-se no conjunto de resultados obtidos, pode-se concluir que de modo geral a sinalização para a aquisição de competência para conversão do MAR em gemas caulinares coincidiu, com uma ampla gama de eventos estruturais, fisiológicos e bioquímicos, como distúrbios no transponte polar de auxina, redução temporária nos teores de citocininas (principalmente do tipo iP, concomitante à predominância de Z), aumento na concentração de etileno (mediada pela elevação dos teores de citocininas) bem como de giberelinas e ácido abscísico, regulação nos teores de ascorbato e glutationa, e de elevações na concentração de óxido nítrico e cálcio citossólico na região próxima ao centro quiescente (CQ) .

Esse conjunto de sinais pareceu atuar de maneira coordenada nos diferentes passos que levam à aquisição de competência, bem como na conversão do MAR em gemas per se. Essa atuação pareceu girar em torno da indução de desorganização e diferenciação celular dentro do MAR, culminando no isolamento de um grupo de células com características meristemáticas aparentemente derivadas da perda de quiescência do CQ, as quais, por sua vez, mostraram-se as protagonistas mais diretamente envolvidas com a re-organização do MAR e o estabelecimento de um novo meristema caulinar. 


\section{RESUMO}

Durante esse trabalho de pesquisa verificou-se que a aquisição de competência para conversão de ápices radiculares de Catasetum fimbriatum em gemas caulinares aumentava à medida que as plantas envelheciam. Esse processo esteve relacionado ao estabelecimento do crescimento determinado das raízes e com a parada da atividade e re-organização estrutural do meristema apical radicular (MAR). Este, quando ainda jovem e destituído de competência para a conversão em gemas, apresentava uma organização do tipo fechada, ao passo que em estágios avançados do envelhecimento este padrão transformou-se em um tipo aberto, marcado pela diferenciação e predominância de células parenquimáticas. Tais alterações, aparentemente, ocorreram com a concomitante perda das características e funções do centro de quiescente (CQ). De maneira complementar, constatou-se que a aquisição de competência do MAR para conversão em gemas estava correlacionada a uma série de alterações metabólicas, as quais, supostamente, participaram de uma condição fisiológica favorável a esse processo. Com base no conjunto de dados obtidos, pode-se observar que os teores endógenos de importantes participantes na progressão de divisões celulares, tais como auxinas, citocininas e formas reduzidas de ascorbato e glutationa tenderam a diminuir durante o envelhecimento das raízes. Por outro lado, durante esse mesmo período, o conteúdo de alguns hormônios envolvidos na sinalização de condições de estresse ou diferenciação celular, tais como etileno, ácido abscísico e giberelinas tenderam a aumentar. As concentrações relativas de importantes sinalizadores secundários, tais como óxido nítrico e cálcio citossólico também apresentaram aumento conspícuo na região do MAR durante o envelhecimento. Agregando elementos a estas constatações, verificou-se que o transporte polar de auxina seria um importante sinal posicional para a manutenção das características e função do MAR, uma vez que o seu bloqueio em plantas jovens foi suficiente para causar a aquisição da competência do MAR, no entanto, o processo de conversão não era consolidado enquanto os ápices radiculares permaneceram ligados às plantas. $A$ aplicação de etileno em plantas jovens, por sua vez, desencadeou efeitos similares; no entanto, além de induzir a competência, esse hormônio também proporcionou a conversão dos MARs em gemas via aumento nos teores endógenos de citocininas. O tratamento de ápices radiculares jovens com diferentes tipos de citocininas revelaram que citocininas do tipo isopenteniladenina (iP e iPR) mostraram-se mais de perto relacionadas à retenção de características radiculares, ao passo que as do tipo zeatina ( $Z$ e ZR) apresentou maior influência e presença em condições em que as características radiculares foram perdidas. Por outro lado, a aplicação de substâncias moduladoras do balanço redox em ápices radiculares 
jovens mostrou que o estresse oxidativo proporcionou a aquisição de competência do MAR para conversão em gemas. Essa mesma tendência foi observada com a aplicação de concentrações relativamente elevadas de substâncias indutoras da elevação dos teores de óxido nítrico e cálcio citossólico nos tecidos. Os ápices radiculares com competência parcialmente estabelecida, analisados logo nas primeiras horas após o isolamento, revelaram que sua separação da planta-mãe acelerava as mudanças morfológicas que naturalmente ocorrem no MAR em estágios avançados do envelhecimento. Durante esse mesmo período, verificou-se uma queda rápida nos teores endógenos de citocininas (principalmente do tipo iP), proporcionando a predominância de citocininas do tipo $Z$ durante a maior parte do primeiro dia de isolamento dos explantes, a qual coincidiu com a mudança no padrão de organização do MAR do tipo intermediário-aberto para o totalmente aberto. O avanço das modificações no ápice radicular após esse período desencadeou o estabelecimento do meristema caulinar, cujo evento esteve relacionado a uma tendência de aumento nos teores de citocininas e de ascorbato após o primeiro dia de isolamento. Dessa forma, os estágios mais avançados do envelhecimento radicular, bem como a separação de ápices radiculares com competência parcialmente estabelecida, parecem desencadear e aumentar a competência do MAR para conversão por meio de modificações morfológicas e fisiológicas muito similares nos ápices radiculares. Essas alterações envolveram a perda das características radiculares, a qual parece depender de alterações no controle exercido pelo CQ sobre o desenvolvimento das demais células no MAR. Esses eventos na região do CQ se revelaram condição sine qua non para a complementação da aquisição de competência do MAR, sendo esta dependente da intensidade das perturbações sobre o controle da organização do MAR. Dessa forma, a conversão do meristema apical radicular de $C$. fimbriatum em gemas caulinares parece decorrer da formação de um novo grupo de células na antiga região do $\mathrm{CQ}$ do MAR alterado. Essas células pareceram competentes para responder a diferentes estímulos que as direcionariam a uma nova rota do desenvolvimento que, nesse caso, seria o estabelecimento de um meristema caulinar com conseqüente desenvolvimento de uma gema vegetativa. 


\section{ABSTRACT}

During this research work, it was noticed that competence acquisition for the conversion of Catasetum fimbriatum root tips into buds was related to the plant ageing.

This process seems to be coupled with the establishment of the determinate root growth and with the cessation in the activity and structural re-organization of the root apical meristem (RAM). Young and non-competent root tips showed a closed RAM architecture, and the ageing process stimulated the establishment of an open organization in the RAM, as indicated by a higher level of differentiation and a predominance of parenchymatic cells in the old root apices. These alterations were concomitant with the modifications on the characteristics and functions of quiescent center (QC). In agreement with these observations, the competence acquisition to the conversion of the MAR into buds was linked to a series of metabolic alterations, which probably play a role in this process. Based on the data obtained, it was observed that the endogenous levels of important components of the cell division progression, such as auxins, cytokinins and the reduced forms of ascorbate and glutathione showed a tendency of decrease during the root ageing. On the other hand, during this same period, the content of some hormones involved in signalling events of stress conditions or cellular differentiation, such as ethylene, abscisic acid and gibberellins exhibited a pattern of increase. The relative concentrations of important second messengers, such as nitric oxide and cytosolic calcium also displayed a marked increased in the RAM region during the ageing. Additionally, it was noticed that the auxin polar transport represents an important positional signal for the maintenance of the RAM characteristics and functions, once treatments that blocked the transport of this hormone promoted the MAR competence acquisition even in young plants, although, the conversion process did not complete while the root tips were maintained attached to the plants. The treatment of young plants with ethylene, on the contrary, caused similar effects; however, besides inducing the competence, this hormone also promoted the RAM conversion into buds via the elevation in the endogenous levels of cytokinins. The treatment of young root tips with different types of cytokinins indicated that iPtype cytokinins (iP and iPR) were more closely associated to the preservation of the root characteristics, while the Z-type cytokinins ( $Z$ and ZR) showed a higher importance when the root characteristics were lost. Furthermore, the treatment of young root apices with compounds that cause alterations in the cellular redox status indicated that the oxidative stress stimulated the competence acquisition for the RAM conversion into buds. This same tendency was observed with the application of relatively high concentrations of compounds that induce elevations in the levels of nitric oxide and cytosolic calcium in the tissues. The 
analyses carried out during the first hours after the isolation of partially competent root apices indicated that the detachment of the root tips from the original plants accelerated the morphological modifications that naturally occur at advanced stages of ageing. During this same period, it was observed a rapid decrease in the endogenous levels of cytokinins (specially of the iP-type), leading to a predominance of the Z-type cytokinins during the first day after the isolation of the explants, which coincided with the alteration of the RAM architecture from the intermediate-open type to the completely open type. After the first day of isolation, the progress in the root apices modifications resulted in the establishment of the shoot meristem, which was accompanied by an elevation in the endogenous levels of cytokinins and ascorbate. Therefore, advanced stages of root ageing, as well the isolation of the partially competent root apices, seem to increase the competence for the RAM conversion into buds via similar morphological and physiological changes in the root apices. These alterations involved the loss of the root characteristics, which possibly resulted from modifications in the control of the QC on the development of the other cells in the RAM. These events in the QC represent a sine qua non condition for the completion of the MAR competence acquisition, which is affected by the intensity of the perturbations on the control of the RAM organization. Therefore, the conversion of root apical meristem of $\mathrm{C}$. fimbriatum into buds probably results from the formation of a new group of cells in the region of the QC of the altered RAM. These cells seem to be competent to respond to different stimulus that would directionate them to a new developmental route that, in this case, consists in the establishment of a shoot meristem.. 


\section{REFERÊNCIAS BIBLIOGRÁFICAS}

ABELES FB, MORGAN PW, SALTVEIT ME (1992) Ethylene in plant biology, 2nd ed. San Diego: Academic Press.

AIDA M, BEIS D, HEIDSTRA R, WILLEMSEN V, BLILOU I, et al. (2004) The PLETHORA genes mediate patterning of the Arabidopsis root stem cell niche. Cell. 119: 109-120.

ALLAN AC, FRICKER MD, WARD JL, BEALE JL, TREWAVAS AJ (1994) 2 transduction pathways mediate rapid effects of abscisic acid in Commelina communis. Plant Cell 6: 1319-1328.

ALLEN GJ, KWAK JM, CHU SP, LLOPIS J, TSIEN RY, HARPER JF, SCHROEDER JI. (1999). Cameleon calcium indicator reports cytoplasmic calcium dynamics in Arabidopsis guard cells. The Plant J. 19: 735-747.

AN L, LIU Y, ZHANG M, CHEN T, WANG X. (2005) Effects of nitric oxide on growth of maize seedling leaves in the presence or absence of ultraviolet-B radiation. J. Plant Physiol. 162, 317-326.

ANANIEVA K, MALBECKB J, NEKB MK, STADENA JV (2004) Changes in endogenous cytokinin levels in cotyledons of Cucurbita pepo (zucchini) during natural and dark-induced senescence. Physiol. Plant. 122: 133-142.

ANIL VS, RAO KS (2001) Calcium-mediated signal transduction in plants: A pespective on the role of $\mathrm{Ca}^{2+}$ and CDPKs during early plant development. J. Plant Physiol. 158: 1237-1256.

ARMSTRONG, J.E.; HEIMSCH, C. (1976) Ontogenetic reorganization of the root meristem in the Compositae. Am. J. Bot. 63: 212-219.

ARRIGONI, O. (1994) Ascorbate sytem in plant development. J. Bioenerg. Biomembr. 26: 407-419.

ARRIGONI, O.; DE TULLIO, M.C. (2000) The role of ascorbic acid in cell metabolism: between genedirected functions and unpredictable chemical reactions. J. of Plant Physiol. 157: 481-488.

AUER, C.A. (2002) Discoveries and dilemmas concerning cytokinin metabolism. J. of Plant Growth Regul. 24: 24-34.

BARLOW, P. (1997) Stem cells and founder zones in plants, particularly their roots. In: Stem Cells. ed. CS POTTEN. pp. 29-57. London: Academic. 474 pp.

BARWE, S.P.; SATHIYABAMA, M.; JAYABASKARAN, C. (2001a) Induction of chitinase activity by exogenous cytokinins in excised dark-grown cucumber cotyledons: involvement of $\mathrm{Ca}^{2+}$ and staurosporine-sensitive protein kinase(s) in cytokinin signaling. J. Plant Physiol. 158: 1 - 7.

BARWE, S.P.; SATHIYABAMA, M.; JAYABASKARAN, C. (2001b) The requirements for $\mathrm{Ca}^{2+}$, protein phosphorylation and concurrent protein synthesis for zeatin signaling of acidic chitinase transcript accumulation in Cucumis sativus L. J. Plant Physiol. 158: 1117-1123.

BAUM, S.F.; DUDROVSKY, J.G.; ROST, T.L. (2002) Apical organization and maturation of the cortex and vascular cylinder in Arabidopsis thaliana (Brassicaceae) roots. Am. J. Bot. 89: 908-920. 
BELLIGNI, M.V.; LAMATTINA, L. (2001) Nitric oxide in plants: the history is just beginning. Plant Cell Env. 24, 267-278.

BELMONTE MF, DONALD G, REID DM, YEUNG EC, STASOLLA C (2005) Alterations of the glutathione redox state improve apical meristem structure and somatic embryo quality in white spruce (Picea glauca). J. Exp. Bot. 56:2355-2364.

BEVERIDGE, C.A.; MATHESIUS, U; ROSE, R.J.; GRESSHOFF, P.M. (2007) Common regulatory themes in meristem development and whole-plant homeostasis. Cur. Op. in Plant Biol. 2007, 10:44-51

BIRNBAUM, K.; BENFEY, P.N. (2004) Network building: transcriptional circuits in the root. Cur. Op. in Plant Biol. 7:582-588.

BLEECKER, A.B.; ESTELLE, M.A.; SOMERVILLE, C.; KENDE, H. (1988) Insensitivity to ethylene conferred by a dominant mutation in Arabidopsis thaliana. Science. 242: 1086-89.

BLOOM, A.J.; MEYERHOFF, P.A.; TAYLOR, A.R.; ROST, T.L. (2003) Root development and absortion of ammonium and nitrate from the rhizosphere. J. Plant Growth Regul. 21: 416-431.

BOLLMARK, M.; CHEN, H-J.; MORITZ, T.; ELIASSON, L. (1995) Relations between cytokinin level, bud development and apical control in Norway spruce, Picea abies. Physiol. Plant. 95: 563-568.

BONHOMME, F.; KURZ, B.; MELZER, S.; BERNIER, G.; JACQMARD, A. (2000) Cytokinin and gibberelin active SaMADS A, a gene apparently involved in regulation of the floral transition in Sinapis alba. Plant J. 24: 103-111.

BRAULT, M.; MALDINEY, R. (1999) Mechanisms of cytokinin action. Plant Physiol. Biochem. 37 (5): 403-412.

BRIGHT, L.J., LIANG, Y., MITCHELL, D.M., HARRIS, J.M. (2005) The LATD gene of Medicago truncatula is required both for nodule and root development. Mol. Plant-Microbe Interact. 18, 521-532.

BROCARD-GIFFORD, I., LYNCH, T.J., GARCIA, M.E., MALHOTRA, B., FINKELSTEIN, R.R. (2004) The Arabidopsis thaliana ABSCISIC ACID-INSENSITIVE8 encodes a novel protein mediating abscisic acid and sugar responses essential for growth. Plant Cell 16, 406-421.

BURG, S.P.; BURG, E.A. (1967) Molecular requirements for the biological activity of ethylene. Plant Physiol. 42: 144-152.

BUSH, S.B. (1995) Calcium regulation in plant cells and its role in signaling. Ann. Rev. Plant Physiol. Plant Mol. Biol. 46: 95-122.

CASIMIRO I, BEECKMAN T, GRAHAM N, BHALERAO R, ZHANG HM, CASERO P, SANDBERG G, BENNETT MJ (2003) Dissecting Arabidopsis lateral root development. Trends Plant Sci 8:165171.

CASIMIRO I, MARCHANT A, BHALERAO RP, BEECKMAN T, DHOOGE S, SWARUP R, GRAHAM N, INZE' D, SANDBERG G, CASERO PJ, BENNETT M (2001) Auxin transport promotes Arabidopsis lateral root initiation. Plant Cell 13:843-852 
CASSON, S.A.; LINDSEY, K. (2003) Genes and signalling in root development. New Phytol. 158: 1138.

CASTELLANO, M.M.; SABLOWSKI, R. (2005) Intercellular signalling in the transition from stem cells to organogenesis in meristems. Cur. Opin.Plant Biol. 8: 26-31.

CELENZA JL J, GRISAFI PL, FINK GR. (1995) A pathway for lateral root formation in Arabidopsis thaliana. Genes Dev. 9:2131-42.

CHAMPAGNAT, M. (1971) Recherches sur la multiplication vegetative de Neottia nidus-avis Rich.

CHAPMAN, K.; GROOT, E.P.; NICHOL, S.A.; ROST, T.L. (2003) Primary root growth and the pattern of root apical meristem organization are coupled. J. Plant Growth Regul. 21: 287-295.

CHENG, J.C.; SEELEY, K.A.; SUNG, Z.R. (1995) RML1 and RML2, Arabidopsis genes required for cell proliferation at the root tip. Plant Physiol. 107:365-76.

CHIWOCHA, S.D.S.; ABRAMS, S.R.; AMBROSE, S.J.; CUTLER; A.J.; LOEWEN, M.; ROSS, A.R.S.; KERMONE, A.R. (2003) A method for profiling classes of plant hormones and the metabolites using liquid chromatography-electrospray ionization tandem mass spectrometry: an analysis of hormone regulation of thermodormancy of lettuce (Lactuca sativa L.) seeds. The Plant Journal. 35:405-17.

CHOW, B.; MCCOURT, P. (2004) Hormone signalling from a developmental context. J. Exp. Bot. 55 (395): 247-251.

CLARK, D.G.; GUBRIUM, E.K.; BARRETT, J.E.; NELL, T.A.; KLEE, H.J. (1999) Root formation in ethylene- insensitive plants. Plant Physiol. 121: 53-59.

CLOWES, F.A.L. (1981) The difference between open and closed meristems. Ann. Bot. 48:761-67.

CLOWES, F.A.L. (1982) Changes in cell population kinetics in an open meristem during root growth. New Phytol. 91:741-48.

COLLI, S.; KERBAUY, G.B. (1993) Direct root-tip conversion of Catasetum fimbriatum into protocormlike bodies. Effects of auxin and cytokinin. Plant Cell Tis. Org. Cult. 33: 39-44.

CÓRDOBA-PEDREGOSA, M. DEL C.; CÓRDOBA, F.; VILLALBA, J.M.; GONZÁLEZ-REYES, J.A. (2003) Zonal changes in ascorbate and hydrogen peroxide contents, peroxidase, and ascorbaterelated enzyme activities in onion roots. Plant Physiol. 131: 697-706.

CORREA-ARAGUNDE, N., GRAZIANO, M. AND LAMATTINA, L. (2004) Nitric oxide plays a central role in determining lateral root development in tomato. Planta 218, 900-905.

CORREA-ARAGUNDE, N., GRAZIANO, M., CHEVALIER, C. AND LAMATTINA, L. (2006) Nitric oxide modulates the expression of cell cycle regulatory genes during lateral root formation in tomato. $\mathbf{J}$. Exp. Bot. 57, 581-588.

CREUS CM, GRAZIANO M, CASANOVAS EM, PEREYRA MA, SIMONTACCHI M, PUNTARULO S, BARASSI CA, LAMATTINA L. (2005) Nitric oxide is involved in the Azospirillum brasilense induced lateral root formation in tomato. Planta 10.1007/s00425-005-1523-7. 
DAS, R.; BAGGA, S.; SOPARY, S.K. (1987) Involvement of phosphoinositides, calmodulin and glyoxylase I in cell proliferation in callus cultures of Amaranthus paniculatus. Plant Sci. 53:45-51.

DE TULLIO, M.C.; PACIOLLA, C.; DALLA VESSHIA, F.; RASCIO, N.; D'EMERICO, S.; DE GARA, L.; LISO, R.; ARRIGONI, O. (1999) Changes in onion root development induced by the inhibition of peptidyl-prolyl hydroxylase and influence of the ascorbate system on cell division and elongation. Planta. 209: 424-434.

DEAK, K.I., MALAMY, J. (2005) Osmotic regulation of root system architecture. Plant J. 43, 17-28.

DEL POZO, J.C.; LOPEZ-MATAS, M.A.; RAMIREZ-PARRA, E.; GUTIERREZ, C. (2005) Hormonal control of the plant cell cycle. Physiol. Plant. 123: 173-183.

DI LAURENZIO L, WYSOCKADILLER J, MALAMY JE, PYSH L, HELARIUTTA Y, FRESHOUR G, et al. (1996). The SCARECROW gene regulates an asymmetric cell division that is essential for generating the radial organization of the Arabidopsis root. Cell 86: 423-433.

DINNENY JR; BENFEY PN (2008) Plant Stem Cell Niches: Standing the Test of Time. Cell 132, 553557

DOLAN, L.; JANMAAT, K.; WILLEMSEN, V.; LINSTEAD, P.J.; POETHIG S.; ROBERTS, K.; SCHERES, B. (1993) Cellular organisation of the Arabidopsis thaliana root. Development. 119:71-84.

ETTLINGER, C. LEHLE, L. (1988) Auxin induces rapid changes in phosphatidylinositol metabolites. Nature. 331: 176-178.

FELDMAN, L.J. (1976) The de novo origin of the quiescent center in regenerating root apices of Zea mays. Planta. 128:207-212

FELDMAN, L.J. (1984) Regulation of root development. Ann. Rev. Plant Physiol. Plant Molec. Biol. 35: $223-242$.

FELDMAN, L.J. (1998) Not so quiet quiescent centers. Trends in Plant Sciences. 3: 80-81.

FINKELSTEIN, R.R., GAMPALA, S.S.L., ROCK, C.D. (2002). Abscisic acid signaling in seeds and seedlings. Plant Cell, Suppl. 2002, S15-S45.

FISCHER, D.B. (1968) Protein staining of ribboned epon sections for light microscopy. Histochemie, 16: $92-96$.

FOLTA, K.M.; PONTIN, M.A., KARLIN-NEUMANN, G.; BOTTINI, R.; SPALDING, E.P. (2003) Genomic and physiological studies of early crytochrome 1 action demonstrate roles for auxin and gibberelin in the control of hypocotyl growth by blue light. The Plant J. 36: 203-214.

FRANCESCHI, V.R.; E NAKATA, P.A. (2005) Calcium Oxalate in Plants: Formation and Function. Annu. Rev. Plant Biol. 56:41-71

FRANCIS, D.; SORRELL, D. A. (2001) The interface between the cell cycle and plant growth regulators: a mini review. Plant Growth Reg. 33: 1-12.

FRICKER, M.D.; MAY, M., MEYER, A.J.; SHEARD, N.; WHITE, N.S. (2000) Measurement of glutathione levels in intact roots of Arabdopsis. J. Microsc.198: 162-173. 
FRIML, J.; YANG, X.; MICHNIEWICZ, M.; WEIJERS, D.; QUINT, A.; ET AL. (2004) A PINOID- dependent binary switch in apical-basal PIN polar targeting directs auxin efflux. Science. 306: 862-65.

FU X, HARBERD NP. (2003) Auxin promotes Arabidopsis root growth by modulating gibberellins response. Nature 421:740-43.

FUJIMURA, T.; KOMAMINE, A. (1979) Involvement of endogenous auxin in somatic embryogenesis in a carrot cell suspension culture. Z. Pflanzenphysiol. 95: 13-19.

GABALDON C, GOMEZ ROS LV, PEDRENO MA, ROS BARCELO A. (2005) Nitric oxide production by the differentiating xylem of Zinnia elegans. New Phytol. 165, 121-130.

GILROY S, FRICKER MD, READ ND, TREWAVAS AJ (1991). Role of calcium in signal transduction of Commelina guard cells. Plant Cell 3: 333-344.

GRABOV A, BLATT MR (1998) Membrane voltage initiates $\mathrm{Ca}^{2+}$ waves and potentiates $\mathrm{Ca}^{2+}$ increases with abscisic acid in stomatal guard cells. Proc. Natl. Acad. Sci. USA 95: 4778-4783

GROOT EP, ROST TL. (2001) Cell division patterns and root apical organization. In: FRANCIS D, ed. The plant cell cycle and its interfaces. Sheffield: Sheffield Academic Press Ltd, 137-158.

GUBLER, F., CHANDLER, P. M., WHITE, R. G., LLEWELLYN, D. J. \& JACOBSEN, J. V. (2002) Gibberellin signaling in barley aleurone cells. Control of SLN1 and GAMYB expression. Plant Physiol. 129, 191-200.

GUO F-Q, OKAMOTO M, CRAWFORD MJ. (2003) Identifcation of a plant nitric oxide synthase gene involved in hormonal signaling. Science 302, 100-103.

HAECHER, A.; GROSS-HARDT, R.; GEIGES, B.; SARKAR, A.; BREUNINGER, H.; HERRMANN, M.; LAUX, T. (2004) Expression dynamics of WOX genes mark cell fate decisions during early embryonic patterning in Arabidopsis thaliana. Development. 131:657-668.

HANSTEIN, J. (1868) Die Scheitelzellgruppe im Vegetationspunkt der Phanerogamen. Festschr Niederrhein Gesel Natur Heilk. 1868:109-134.

HARDTKE, C.S.; BERLETH, T. (1998) The Arabidopsis gene MONOPTEROS encodes a transcription factor mediating embryo axis formation and vascular development. EMBO J. 17:1405-11.

HELARIUTTA, Y.; FUKAKI, H.; WYSOCKA-DILLER, J.; NAKAJIMA, K.; JUNG, J. (2000) The SHORTROOT gene controls radial patterning of the Arabidopsis root through radial signaling. Cell 101:555-67

HEPLER, P.K.; WAYNE, R.O. (1985) Calcium and plant development. Ann. Rev. Plant Physiol. 36: 397-349.

HEWELT A, PRINSEN E, THOMAS M, VAN ONCKELEN H, FREDERICK MEINS, JR (2000) Ectopic expression of maize knotted1 results in the cytokinin-autotrophic growth of cultured tobacco tissues. Planta 210: 884-889

HOBBIE, L.; MCGOVERN, M.; HURWITZ, L.R.; PIERRO, A.; LIU, N.Y.; et al. (2000) The axr6 mutants of Arabidopsis thaliana define a gene involved in auxin response and early development. Development. 127:23-32 
HORIGUCHI, G.; KODAMA, H.; IBA, K. (2003) Mutations in a gene for plastid ribosomal protein S6-like protein reveal novel developmental processes required for the correct organization of lateral root meristem in Arabidopsis. Plant J. 33:521-29

HOSSEINI-NASR, M.; RASHID, A. (2002) Thidiazuron-induced shoot-bud formation on root segments of Albizzia julibrissin is an apex-controlled, light-independent and calcium-mediated response. Plant Growth Regul. 36: 81-85.

HU, X., NEILL, S.J., TANG, Z. AND CAI, W. (2005) Nitric oxide mediates gravitropic bending in soybean roots. Plant Physiol. 137, 663-670.

HU, X.Y.; NEILL, S.J.; TANG, Z.C.; CAI, W.M. (2005) Nitric oxide mediates gravitropic bending in soybean roots. Plant Physiol. 137:663-670.

ILARSLAN H, PALMER RG, HORNER HT. (2001) Calcium oxalate crystals in developing seeds of soybean. Ann. Bot. 88:243-57

ILARSLAN H, PALMER RG, IMSANDE J, HORNER HT. (1997) Quantitative determination of calcium oxalate in developing seeds of soybean (Leguminosae). Am. J. Bot. 84:1042-46

IVANOV VB. 2004. Meristem as a self-renewing system: maintenance and cessation of cell proliferation (a review). Russian J. of Plant Physiol. 51: 834-847. I

JAWORSKI, E.G. (1971) Nitrate reductase assay in intact plant tissue. Bioch. Bioph. Res. Commun. 43: $1274-1279$.

JIANG, K., MENG, Y.L., AND FELDMAN, L.J. (2003) Quiescent center formation in maize roots is associated with an auxin-regulated oxidizing environment. Develop., 130:1429-1438.

JIANG, K.; FELDMAN, L.J. (2003) Root meristem establishment and maintenance: The role of auxin. J. Plant Growth Regul. 21: 432-440.

JIANG, K.; FELDMAN, L.J. (2005) Regulation of root apical meristem development. Ann. Rev. Cell Dev. Biol. 21:485-509.

KAMÍNEK, M. (1992) Progress in cytokinin research. Trends in Biotecnol. 10: 159-164.

KANDLBINDER A, FINKEMEIER I, WORMUTH D, HANITZSCH M, DIETZ K-J (2004) The antioxidant status of photosynthesizing leaves under nutrient deficiency: redox regulation, gene expression and antioxidant activity in Arabidopsis thaliana. Phys. Plant. 120: 63-73.

KANEKO M, ITOH H, INUKAI Y, SAKAMOTO T, UEGUCHI-TANAKA M, et al. (2003) Where do gibberellin biosynthesis and gibberellin signaling occur in rice plants? Plant J. 35:104-15.

KARNOVSKY, M.J.A. (1965) Formaldehyde Fixative of High-osmolality for use in electron microscopy. J. Cell. Biol. 27: 137-138.

KASKA, D.D., MYLLYLA, R., COOPER, J.B. (1999) Auxin transport inhibitors act through ethylene to regulate dichotomous branching of lateral root meristems in pine. New Phytol. 142: 49-58 
KERBAUY, G. B. (1999). Competência e determinação celular em cultura de células e tecidos de plantas. In: Torres, A. C.; Caldas, L. S. e Buso, J. A . (Eds). Cultura de tecidos e transformação genética de plantas, v. 2. Brasília: Embrapa. 864 p.

KERBAUY, G.B. (1984) Regeneration of protocorm-like bodies through in vitro culture of roots tips of Catasetum (Orchidaceae). Z. Pflanzenphysiol. Bd. 113: 287-291.

KERBAUY, G.B.; COLLI, S. MAJEROWICZ, N. (1995) Manutenção da atividade meristemática apical em caules de Catasetum (Orchidaceae) pelo etileno e escuro: implicações com uma estratégia de micropropagação. In: Resumos do V Congresso Brasileiro de Fisiologia Vegetal, Lavras, p. 3.

KERBAUY, G.B.; ESTELITA, M.E.M. (1996) Formation of protocorm-like bodies from root apex of Catasetum pileatum (Orchidaceae) cultivated in vitro. Some non-hormonal requeriments involved in the regeneration. Rev. Brasil. Fisiol. Veg. 8: 157-159.

KERK N.M.; FELDMAN L.J. (1995) A biochemical model for the initiation and maintenance of the quiescent center: implications for organization of root meristems. Development 121: 2825-2833.

KERK NM, JIANG K, FELDMAN LJ (2000) Auxine metabolism in the root distal meristem. Plant Physiol 112:925-932

KOLLER, A.L. e ROST, T.L. 1988. Structural analysis of waterstorage tissue in leaves of Sansevieria (Agavaceae). Bot. Gaz. 149:260-274.

KOORNNEEF, M., JORNA, M.L., DERSWAN, D., KARSSEN, C.M., 1982. The isolation of abscisic-acid (ABA) deficient mutants by selection of induced revertants in non-germinating gibberellin sensitive lines of Arabidopsis thaliana (L) Heynh. Theor. Appl. Genet. 61, 385-393.

KRAUS, J.E.; KERBAUY, G.B. (1992) Formation of protocorm-like bodies from root apex of Catasetum pileatum (Orchidaceae) cultivated in vitro. Some non-hormonal requeriments involved in the regeneration. Boletim de Botânica. São Paulo. 13: 31-40.

KRAUS, J.E.; MONTEIRO, W.R. (1989) Formation of protocorm-like bodies from root apices of Catasetum fimbriatum (Orchidaceae) cultivated in vitro. I. Morphological aspects. Ann Bot. 64: 491-498.

LAMATTINA, L., GARCIA-MATA, C., GRAZIANO, M. AND PAGNUSSAT, G. (2003) Nitric oxide: the versatility of an extensive signal molecule. Annu. Rev. Plant Biol. 54, 109-136.

LANAHAN, M.B.; YEN, H-C.; GIOVANNONI, J.J.; KLEE, H.J. (1994) The never ripe mutation blocks ethylene perception in tomato. Plant Cell. 6: 521-30.

LETHAM, D.S. (1994) Cytokinins as phytohormones: sites of biosynthesis, translocation, and function of translocated cytokinin. CRC. Boca Raton.

LI, T.R.; NEUMANN, K-H. (1985) Embryogenesis and endogenous hormone content of cell cultures of some carrot varieties (Daucus carota L.) Ber Deutsch Bot. Ges. 98: 227-235.

LUSCHNIG, C.; GAXIOLA, R.A.; GRISAFI, P.; FINK, G.R. (1998) EIR1, a root-specific-protein involved in auxin transport, is required for gravitropism in Arabidopsis thaliana. Genes and Develop. $12: 2175-87$. 
MALAMY, J.E. (2005) Intrinsic and environmental response pathways that regulate root system architecture. Plant Cell Environ. 28:67-77.

MALHO R, KALORITI D, SOUSA E (2006) Calcium and rhythms in plant cells. Biol. Rhythm Res. 37(4): $297-314$

MARKWELL, M.; HAAS, S.M.; BIEBER, L.L.; et al. Modification of lowry procedure to simplify protein determination in membrane and lipoprotein samples. Anal. Bioch. 87 (1): 206-210 1978

MARTIN CE, SCHMITT AK (1989) Unusual water relations in the CAM atmospheric epiphyte Tillandsia usneoides L (Bromeliaceae). Bot.I Gaz. 150, 1-8.

MAY, M.J.; VERNOUX, T.; LEAVER, C.; VAN MONTAGU, M.; INZE, D. (1998) Glutathione homeostasis in plants: Implications for environmental sensing and plant development. J. Exp. Bot. 49:649-67.

MCAINSH MR, BROWNLEE C, HETHERINGTON AM. (1990) Abscisic acid induced elevation of guard cell cytosolic $\mathrm{Ca}^{2+}$ precedes stomatal closure. Nature 343: 186-188.

MCAINSH MR, BROWNLEE C, HETHERINGTON AM. (1992) Visualizing changes in cytosolic free $\mathrm{Ca}^{2+}$ during the response of stomatal guard cells to abscisic acid. Plant Cell 4: 1113-1122.

MILLER, C.O.; SKOOG, F.; OKOMURA, F.S.; VON SALTZA, M.H.; STRONG, F.M. (1956) Isolation, structure and synthesis of kinetin, a substance promoting cell division. J Am Chem Soc. 78:13451350.

MIYAWAKI K, MATSUMOTO-KITANO M, KAKIMOTO T (2004) Expression of cytokinin biosynthetic isopentenyltransferase genes in Arabidopsis: tissue specificity and regulation by auxin, cytokinin, and nitrate. Plant J 37:128-138

MORGAN, P.W.; GAUSMAN, H.W. (1966) Effects of ethylene on auxin transport. Plant Physiol. 41: 45-52.

MULLER, A.; GUAN, C.; GALWEILER, L.; TANZLER, P.; Huijser, P.; MARCHANT, A.; PARRY, G.; BENNET, M.; WISMAN, E.; PALME, K. (1998) AtPIN2 defines a locus of Arabidopsis for root gravitropism control. EMBO Journal. 17: 6903-11.

MURASHIGE, T.; SKOOG, F. (1962) A revised medium for rapid growth and bioassays with tobacco tissue cultures. Physiol. Plant. 15: 473-497.

NAKAJIMA, K.; BENFEY, P.N. (2002) Signalling in and out: control of cell division and differentiation in the shoot and root. The Plant Cell. Supplement: 5265-5276.

NEILL S, DESIKAN R, HANCOCK J (2002) Hydrogen peroxide signalling. Curr Opin Plant Biol 5:388395.

NIEVOLA C.C.; MERCIER, H. (2001) Variações diurnas da atividade in vivo da redutase do nitrato em abacaxizeiro (Ananas comosus (L.) Merr. -- Bromeliaceae). Rev. Bras. Bot. 24(3): 295-301.

NOCTOR, G.; FOYER, C. (1998) Ascorbate and glutathione: keeping active oxygen under control. Ann. Rev. Plant Physiol. Mol. Biol. 49: 249-279. 
NORDSTRÖM A, TARKOWSKI P, TARKOWSKA' D, NORBAEK R, A STOT C, DOLEZAL K (2004) Auxin regulation of cytokinin biosynthesis in Arabidopsis thaliana: a factor of potential importance for auxincytokinin- regulated development. Proc Natl Acad Sci USA 101:8039-8044

OLIVEIRA, V.C.O e SAJO, M.G. (1999) Anatomia foliar de espécies epífitas de Orchidaceae. Rev. Brasil. Bot., 22:365-374.

OSMONT KS, SIBOUT R, HARDTKE CS (2007) Hidden branches: Developments in root system architecture. Annu. Rev. Plant Biol. 58:93-113

OTVOS K, PASTERNAK TP, MISKOLCZI P, DOMOKI M, DORJGOTOV D, SZUCS A, BOTTKA S, DUDITS D, FEHER A (2005) Nitric oxide is required for, and promotes auxin-mediated activation of, cell division and embryogenic cell formation but does not influence cell cycle progression in alfalfa cell cultures. The Plant J. 43, 849-860.

PAGNUSSAT, G.C.; LANTERI, L.M.; LAMATTINA, L. (2003) Nitric oxide and cyclic GMP are messengers in the indole acetic acid-induced adventitious rooting process. Plant Physiol. 132: 1241-1248.

PAGNUSSAT, G.C.; SIMONTACCHI, M.; PUNTARULO, S.; LAMATTINA, L. (2002) Nitric oxide is required for root organogenesis. Plant Physiol. 129: 954-956.

PERES, L.E.P.; KERBAUY, G.B. (1999) Hight cytokinin accumulation following root tip excision changes the endogenous auxin-to-cytokinin ratio during root-to-shoot conversion in Catasetum fimbriatum Lindl (Orchidaceae). Plant Cell Rep. 18: 1002-1006.

PERES, L.E.P.; KERBAUY, G.B. (1999) Hight cytokinin accumulation following root tip excision changes the endogenous auxin-to-cytokinin ratio during root-to-shoot conversion in Catasetum fimbriatum Lindl (Orchidaceae). Plant Cell Rep. 18: 1002-1006.

PERES, L.E.P.; MERCIER, H.; KERBAUY, G.B.; ZAFFARI, G.R. (1997) Níveis endógenos de AIA, citocininas e ABA em uma orquídea acaule e uma bromélia sem raiz, determinadas por HPLC e ELISA. Rev. Bras. de Fisiol. Veg. 9: 169-176.

PERES, L.E.P.; MERCIER, H.; KERBAUY, G.B.; ZAFFARI, G.R. (1997) Níveis endógenos de AIA, citocininas e ABA em uma orquídea acaule e uma bromélia sem raiz, determinadas por HPLC e ELISA. Rev. Bras. de Fis. Veg. 9: 169-176.

PEREZ-PEREZ, J.M. (2007) Hormone signalling and root development: an update on the latest Arabidopsis thaliana research. Func. Plant Biol. 34:163-171

PETERSON, R.L. (1975) The initiation and development of root buds. In: Torrey, J.G.; Clarkson, D.T. (Eds).The development and function of roots. New York:Academic Press. p 125-161.

POTTERS, G.; HOREMANS, N.; BELLONE, S.; CAUBERGS, R.J.; TROST, P. et al.(2004) Dehydroascorbate iffluences the plant cell cycle throug $h$ a glutathione-independent reduction mechanism. Plant Physiol. 134:1479-87

PRAYITNO, J.; ROLFE, B.G.; MATHESIUS, U. (2006) The ethylene-insensitive sickle mutant of Medicago truncatula shows altered auxin transport regulation during nodulation. Plant Physiol. 142: $168-80$. 
PURGATTO, E., NASCIMENTO, J.R.O.; LAJOLO, F.M.; CORDENUNSI, B. R. (2002) The onset of starch degradation during banana ripening is concomitant to changes in the content of free and conjugated forms of indole-3-acetic acid. J. of Plant Physiol. 159: 1105-1111.

RIEFLER M, NOVAK O, STRNAD M, SCHMULLING T. (2006) Arabidopsis cytokinin receptor mutants reveal functions in shoot growth, leaf senescence, seed size, germination, root development, and cytokinin metabolism. Plant Cell 18:40-54.

RIOV, J.; YANG, S.F. (1989) Ethylene and auxin-ethylene interaction in adventitious root formation in mung bean cuttings. In. CLIJSTERS et al. (eds). Biochemical and Physiological Aspects of ethylene production in lower and higher plants. Dordrecht: Kluwer Academic Publishers, p. 151-6.

ROMANOV, G.A.; LOMINA, S.N.; RAKOVAA, N.Y.; HEYLB A., SCHMÜLLING, T. (2008) Does NO play a role in cytokinin signal transduction? FEBS Letters 582: 874-880.

ROST, T.L.; BAUM, S. (1988) On the correlation of primary root length, meristem size and protoxylem tracheary element position in pea seedlings. Am. J. Bot. 75: 414-424.

RUDD JJ; FRANKLIN-TONG VE (2001) Unravelling response-specificity in $\mathrm{Ca}^{2+}$ signalling pathways in plant cells. New Phytol. $151: 7-33$

SABATINI , S., R.; HEIDSTRA, M.; WILDWATER, SCHERES, B. (2003). SCARECROW is involved in positioning the stem cell niche in the Arabidopsis root meristem. Genes \& Development 17: 354358.

SABATINI, S.; BEIS, D.; WOLKENFELT H., MURFETT, J.; GUILFOYLE, T., MALAMY, J.; BENFEY, P.; LEYSER, O., BECHTOLD, N.; WEISBEEK, P.; SCEHERES, B. (1999) An auxin-dependent distal organizer of pattern and polarity in the Arabidopsis root. Cell. 99, 463-472.

SABLOWSKI R. (2007) Flowering and determinacy in Arabidopsis. J. of Exp. Bot. 58: 899-907.

SACHS, T. (1981) The control of patterned differentiation of vascular tissues. Adv. Bot. Res. 9, 151262

SÁNCHEZ-FERNÁNDEZ, R.; FRICKER, M.; CORBEN, L.B.; WHITE, N.S.; SHEARD, N.; LEAVER, C.J.; van MONTAGU, M.; INZÉ, D.; MAY, M.J. (1997) Cell proliferation and hair tip growth in the Arabidopsis root are under mechanistically different forms of redox control. Proc. Natl. Acad. Sci. USA 94: 2745-2750.

SARKAR, A. K., LUIJTEN, M., MIYASHIMA, S., LENHARD, M., HASHIMOTO, T., NAKAJIMA, K., SCHERES, B., HEIDSTRA, R. AND LAUX, T. (2007). Conserved factors regulate signalling in Arabidopsis thaliana shoot and root stem cell organizers. Nature 446, 811-814.

SAUNDERS, M.J. (1990) Calcium and plant hormone action. Soc. Exp. Biol. 1: 271-283.

SAUNDERS, M.J. (1992) Cytokinin signal transduction through $\mathrm{Ca}^{2+}$ in mosses. In: Karssen C.M., Van Loon, L. C.; Vreugdenhil, D. (eds) Progress in plant growth regulation. Kluwer, Dordrecht, pp. 65-72. 
SCHROEDER JI, HAGIWARA S. (1990) Repetitive increases in cytosolic $\mathrm{Ca}^{2+}$ of guard cells by abscisic acid activation of nonselective $\mathrm{Ca}^{2+}$ permeable channels. Proc. Natl. Acad. Sci. USA 87: 93059309.

SEAGO, J.L.; HEIMSCH, C. (1969) Apical organization in roots of the Convolvulaceae. Am. J. Bot. 56: 131-138.

SHISHKOVA, S; ROST, T.L.; DUBROVSKY, J.G. (2008) Determinate Root Growth and Meristem Maintenance in Angiosperms. Ann. of Bot. 101: 319-340.

SHUNSUKE SAIGA, S.; FURUMIZU,C.; YOKOYAMA, R.; KURATA2,T.; SATO,S.; KATO,T; TABATA,S.; SUZUKI, M.; KOMEDA, Y. (2008) The Arabidopsis OBERON1 and OBERON2 genes encode plant homeodomain finger proteins and are required for apical meristem maintenance. Development 135, 1751-1759

SILVEIRA, M. (1989). Preparo de amostras biológicas para microscopia eletrônica de varredura. In: Souza, I.W. (Ed). Manual básico sobre técnicas em microscopia eletrônica. Rio de Janeiro: Sociedade Brasileira de Microscopia Eletrônica. P. 71-105.

SKOOG, F.; MILLER, C.O. (1957) Chemical regulation of growth and organ formation in plant tissues cultured in vitro. Symp. Soc. Exp. Biol. 11: 118-231.

STEPANOVA, A.N.; HOYT, J.M.; HAMILTON, A.A.; ALONSO, J.M. (2005) A link between ethylene and auxin uncovered by the characterization of two root-specific ethylene-insensitive mutants in Arabidopsis. The Plant Cell17: 2230-42.

STOREY, R.; JONES, R.G.W.; SCHACHTMAN, D.P.; TREEBY, M.T. (2003) Calcium-accumulating cells in the meristematic region of grapevine root apices. Funct. Plant Biol. 30:719-27

SUTTLE, J.C. (1988) Effect of ethylene treatment on polar IAA transport, net IAA uptake and specific binding of N-1-naphthylphthalamic acid in tissues and microsomes isolated from etiolated pea epicotyls. Plant Phys. 88: 795-799.

SUZUKI, R.M.; KERBAUY, G.B.; ZAFFARI, G.R. (2004) Endogenous hormonal levels and growth of dark-incubated shoots of Catasetum fimbriatum. J. Plant Phys. 161 (8): 929-935.

SUZUKI, RG (2005) Efeitos da luz, fitormônios e alguns nutrientes sobre o comportamento do meristema caulinar de Catasetum fimbriatum (Morren) Lindl. (Orchidaceae). Tese de doutorado. Instituto de Biociências da Universidade de São Paulo, 143p.

SWARUP, R.; PARRY, G.; GRAHAM, N.; ALLEN, T.; BENNETT, M. (2002) Auxin cross-talk: interation of signalling pathways to control plant development. Plant Mol. Biol. 49: 411-426.

TIMMERS, A.C.J.; REISS, H-D; BOHSUNG, J.; TRAXEL, K.; SCHEL, J.H.N. (1996) Localization of calcium during somatic embryogenesis of carrot (Daucus carota L.). Protoplasma. 190: 107-118.

TRETYN, A.; WAGNER, G.; FELLE, H.H. (1991) Signal transduction in Sinapis alba root hairs: auxins as external messengers. J. Plant physiol. 139:187-193

TREWAVAS, A . (1999) Le calcium, C'est la vie: Calcium makes waves. Plant Physiol. 120: 1-6. 
TUCKER, E.B. (1990) Calcium-loaded 12-bis(2-aminophenoxy)ethaneNNN'N'-tetraacetic acid blocks cell-to-cell diffusion of carboxy-fluorescein in staminal hairs of Setcreasea purpurea. Planta. 182: 34-38.

TUN, N.N., HOLK, A.; SCHERER, G.F.E. (2001) Rapid increase of NO release in plant cell cultures induced by cytokinin. FEBS Letters 509: 174-176.

TUN, N.N.; LIVAJA, M.; KIEBER, J.J.; SCHERER, G.F.E. (2008) Zeatin-induced nitric oxide (NO) biosynthesis in Arabidopsis thaliana mutants of $\mathrm{NO}$ biosynthesis and of two-component signaling genes. New Phytol. 178: 515-531.

UEDA, M.; MATSUI, K.; ISHIGURO, S.; SANO, R.; WADA, T.; et al. (2004) The HALTED ROOT gene encoding the $26 \mathrm{~S}$ proteasome subunit RPT2a is essential for the maintenance of Arabidopsis meristems. Development. 131:2101-11

VACIN, E.F.; WENT, F.W. (1949) Some pH changes in nutrient solutions. Bot. Gaz. 110: 605-617.

VAN DEN BERG, C.; WILLEMSEN, V.; HENDRIKS, G.; WEISBEEK, P.; SCHERES, B. (1997) Shortrange control of cell differentiation in the Arabidopsis root meristem. Nature 390:287-89

VAN LOON L.C., GLICK BR. (2004) Increased Plant Fitness by Rhizobacteria In: Sandermann H. Molecular ecotoxicology of plants. Berlin and Heidelberg: Springer-Verlag. pp 177- 207.

VANOV, V.B. (2007) Meristem as a self-renewing system: Maintenance and cessation of cell proliferation (A Review). Russian J. of Plant Physiol., 51(6):834-847.

VEIT, B. (2004) Determination of cell fate in apical meristems. Cur. Opin. Plant Biol. 7: 57-64.

VEIT, B. (2006). Stem cell signalling networks in plants. Plant Mol. Biol. 60: 793-810.

VERNOUX, T.; WILSON, R.C.; SEELEY, K.A.; REICHHELD, J.-P.; MUROY, S.; BROWN, S.; MAUGHAN, S.C.; COBBETT, C.; VAN MONTAGU, M.; INZÉ, D.; MAY, M.J.; SUNG, Z.R.; (2000) The ROOT MERISTEMLESS1/CADMIUM SENSITIVE 2 gene defines a glutathione-dependent pathway involved in initiation and maintenance of cell division during postembryonic root development. Plant Cell 12: 97-109.

VIETEN, A.; SAUER, M.; BREWER, P.B.; FRIML, J. (2007) Molecular and cellular aspects of auxintransport-mediated development. Trends in Plant Sci. 12(4): 160-168.

VOGLER H, KUHLEMEIER C. (2003) Simple hormones but complex signaling. Cur. Op. in Plant Biol. $6(1): 51-56$

VOLK, G.M.; LYNCH-HOLM, V.J.; KOSTMAN, T.A.; GOSS, L.J.; FRANCESCHI, V.R. (2002) The role of druse and raphide calcium oxalate crystals in tissue calcium regulation in Pistia stratiotes leaves. Plant Biol. 4:34-45

VON GUTTENBERG, H. (1968) Der primäre Bau der Angiospermenwurzel. Handbuch der Pflanzenanatomie. Band VIII. Teil 5. Berlim: Gebruder Borntrager.

WEATHERBURN, MV (1967) Phenol-hipoclorite reaction for determination of ammonia. Anal. Chem. 39:971-974. 
WERNER, T.; MOTYKA, V.; LAUCOU, V.; SMETS, R.; VAN ONCKELEN, H.; SCHMÜLLING, T. (2003) Cytokinin - deficient transgenic Arabidopsis plants show multiple developmental alterations indicating opposite functions of cytokinins in the regulation of shoot and root meristem activity. The Plant Cell. 15: 2532-2550.

WHITE, P.J.; BROADLEY, M.R. (2003) Calcium in plants. Ann. of Bot. 92: 487-511.

WILSON ID, NEILL SJ, HANCOCK JT. (2008) Nitric oxide synthesis and signalling in plants. Plant, cell and environ. 31 (5) 622-631

WILSON, A.K.; PICKETT, F.B.; TURNER, J.C.; ESTELLE, M. (1990) A dominant mutation in Arabidopsis confers resistence to auxin, ethylene and abscisic acid. Molecular General Genetics. 222: 377-387.

YAN LIANG, Y.; MITCHELL, D.M.; HARRIS, J.M. (2007) Abscisic acid rescues the root meristem defects of the Medicago truncatula latd mutant. Develop. Biol. 304: 297-307.

ZHANG C, CZYMMEK KJ, SHAPIRO AD. (2003) Nitric oxide does not trigger early programmed cell death events but may contribute to cell-to-cell signaling governing progression of the Arabidopsis hypersensitive response. Molec. Plant-Micr. Inter. 16, 962-972.

ZHU, T.; O'QUINN, R.L.; LUCAS, W.J.; ROST, T.L. (1998) Directional cellto-cell communication in the Arabidopsis root apical meristem II. Dynamics of plasmodesmatal formation. Protoplasma 203:84-93.

ZIMMERMAN, P.W.; HITCHCOCK, A.E. (1933) Initiation and stimulation of adventitious roots caused by unsuturated hydrocarbon gases. Contrib Boyce Thomson Inst. 5: 351-69. 